

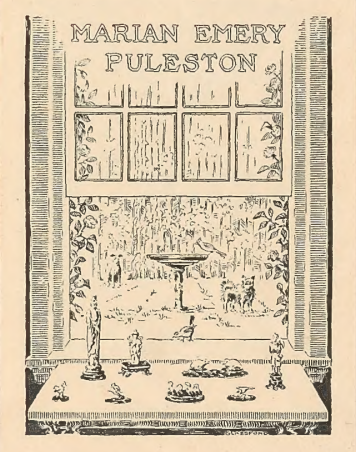







THE

\section{BIRDS OF EUROPE.}

BY

JOHN GOULD, F.L.S., \&.

IN FIVE VOLUMES.

VOL. II.

INSESSORES.

L O N D N :

PRINTED BX RICHARD AND JOHN E. TAYLOR, RED LION COURT, FLEET STREET.

PUBLISHED BY THE AUTHOR, 20 BROAD STREET, GOLDEN SQUARE.

1837. 



\section{LIST OF PLATES.}

VOLUME II.

NotE, $-A s$ the arrangement of the Plates during the course of publication was found to be impracticable, the Numbers here given will refer to the Plates when arranged, and the work may be quoted by them.

\section{N S ESS ORES.}

European Goatsucker Red-collared Goatsucker

Swift

White-bellied Swift

Chimney Swallow

Rufous Swallow

Rock Martin

Martin

Sand Martin

Bee Eater

Roller

Kingsfisher

Black and White Kingsfisher.

Pied Flycatcher

White-collared Flycatcher

Red-breasted Flycatcher

Spotted Flycatcher

Great Shrike

Great Grey Shrike

Lesser Grey Shrike

Red-backed Shrike

Woodchat

Golden Oriole

Black Ouzel, or Blackbird

Ring Ouzel

Migratory Ouzel

Black-throated Thrush

Fieldfare

Missel Thrush

Song Thrush

Redwing

Naumann's Thrush

Pallid Thrush

White's Thrush

Siberian Thrush

Water Ouzel .

Black-bellied Water Ouzel

Pallas's Water Ouzel

Rock Thrush

Blue Thrush

Black Wheatear

Pied Wheatear

Wheatear

Russet Wheatear

Black-eared Wheatear

Whinchat

Stonechat

Redstart

Black Redstart

Blue-throated Warbler
Caprimulgus Europæus, Linn. $\quad$. 51

- ruficollis, Temm. . _ . 52

Cypselus murarius, Temm.
alpinus, Temm. .

Hirundo rustica, Limn. . . 54

-_ rufula, Temm. . . . 55 rupestris, Linn. urbica, Linn. riparia, Linn. . . . 58

Merops Apiaster, Linn. . $\quad 59$

Coracias garrulus, Limn. . . . . 60

Alcedo Ispida, Limn. $\quad . \quad .61$

- rudis, Linn. . .

Muscicapa luctuosa, Temm. . . $\} 63$

$\begin{array}{llll} & & \\ \text { albicollis, Temm. } & . & . & \\ \text { parva, Bechst. } & . & . & 64\end{array}$ grisola, Linn.

Collurio Excubitor, Vig. . 66

— meridionalis, Vig. . . . 67

Lanius Collurio, Linn. ․ . $\quad$. 69

- rufus, Briss.

Oriolus galbula, Linn. .

Merula vulgaris, Ray. _ _ . . 72

—_ torquata, Briss. migratoria, Swains. _ . . . 74

Turdus atrogularis, Temm. $\quad \therefore \quad 75$

—_ pilaris, Linn. ․ . . . 76

- viscivorus, Limn. . . . 77 - musicus, Linn. . . . $\} 78$ Iliacus, Linn. . . . $\quad 7_{79}$ Naumannii, Temm. . @ 79 pallidus, Pall. $\quad . \quad 80$ Whitei, Eyton. . . . 81 Sibericus, Pall. $\quad 82$

Cinclus aquaticus, Bechst. $\quad . \quad 83$ melanogaster, Brehm. . ․ 84 Pallasii, Temm. 85

Petrocincla saxatilis, $\mathrm{Vig}$. . . 86 cyanea, $V i g$.

Saxicola cachinnans, Temm. . . 88 leucomela, Temm. CEnanthe, Bechst. stapazina, Temm. . . . 91 aurita, Temm. . . . . 92 rubetra, Bechst. . . . 93 rubicola, Bechst. . . . 94

Phœnicura ruticilla, Swains. . . 95 tithys, Jard. \& Selb. $\quad \because \quad \because 96$ Suecica, Jard \& Selb. $\quad 97$ 
LIST OF PLATES.

Robin

Alpine Accentor

Hedge Accentor

Mountain Accentor

Reed Locustelle

Brake Locustelle

Willow Locustelle

Creeping Locustelle

Great Sedge Warbler

Olive-tree Salicaria

Reed Wren

Marsh Warbler

Sedge Warbler

Moustached Warbler

Aquatic Warbler

Rufous Sedge Warbler

Fantail Warbler

Cetti's Warbler

Silky Warbler

Nightingale

Thrush Nightingale

Gorget Warbler

Orpheus Warbler

Black-cap

Garden Warbler

Rüppell's Warbler

Sardinian Warbler

Sub-alpine Warbler

Common White-throat

Lesser White-throat

Spectacle Warbler

Marmora's Warbler

Barred Warbler

Dartford Warbler

re

Willow Wren

Chiff-chaff

Wood Wren

Yellow Willow Wren

Melodious Willow Wren

Natterer's Warbler

Richard's Pipit

Meadow Pipit

Tawny Pipit

Rock or Shore Pipit

Tree Pipit

Red-throated Pipit

Pied Wagtail

White-winged Wagtail

White Wagtail

Yellow-headed Wagtail .

Yellow Wagtail

Grey-headed Wagtail

Grey Wagtai

Fire-crested Wren

Golden-crested Wren

Dalmatian Regulus
Erythaca rubecula, Swains. . . . 98

Accentor alpinus, Bechst. . 99

- modularis, Cuv. . . . 100

montanellus, Temm.

Locustella fluviatilis.

avicula, Ray. . . . 103

luscinoïdes. . . 104

certhiola. .105

Salicaria Turdoïdes, Selb. - Olivetorum, Strickl. . 107 arundinacea, Selby. . . . 108 - palustris. 109

- Phragmitis, Selb. . . 110 melanopogon. . * · $\} 111$

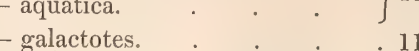

Philomela luscinia, Swains. . 116 - Turdoïdes, Blyth. . . . . 117

Calliope Lathamii. . . . . . . 118

Curruca Orphea. . . . . . 119

_ atricapilla, Bechst. . . . . 120

hortensis, Bechst. . . . 121

Ruppellii. . . . . . 122

melanocephala, Lath. $\quad . \quad 123$

leucopogon. . . . . 124

cinerea, Bechst. . · · $\} 125$

conspicillata. . . . . 126

Sarda. . . . . . 127

nisoria. . . . . . 128

Melizophilus provincialis, Leach. . . 129

Troglodytes Europæus, Cuv. . .130

Sylvia trochilus, Gmel. . . . .

— rufa, Lath*. . . . . . $\} 131$

- sibilatrix, Bechst. . . . . .

Icterina, Vieill. $\quad . \quad$. $\quad \cdot \quad .132$

Hippolais, Temm. . . . . I33

Nattereri, Temm. . . . . . 134

Anthus Richardi, Vieill. . . . . . 135

pratensis, Bechst. . . . . 136

rufescens, Temm.

aquaticus, Bechst. . . . 138

arboreus, Bechst. . . . . 139

rufogularis, Temm. . . . . 140

Motacilla Yarrellii†. . . . . 141

lugubris, Pall. . . . 149

- alba, Linn. . . . . 143

citreola, Pall. . . . . . . 144

flava, Ray. . . . 145

neglecta, Gould. . . . 146

Boarula, Lath. . . . . 147

Regulus ignicapillus, Cuv.
vulgaris, $C u v$.

modestus.

* Named erroneously Sylvia hippolais.

$\uparrow$ Named erroneously Motacilla alba. As I have every reason to believe that this species, one of the most elegant and familiar of our native birds, will prove to be quite distinct from either Motacilla lugubris or Motacilla alba, I would beg leave to name it after my valued friend William Yarrell, Ess. 



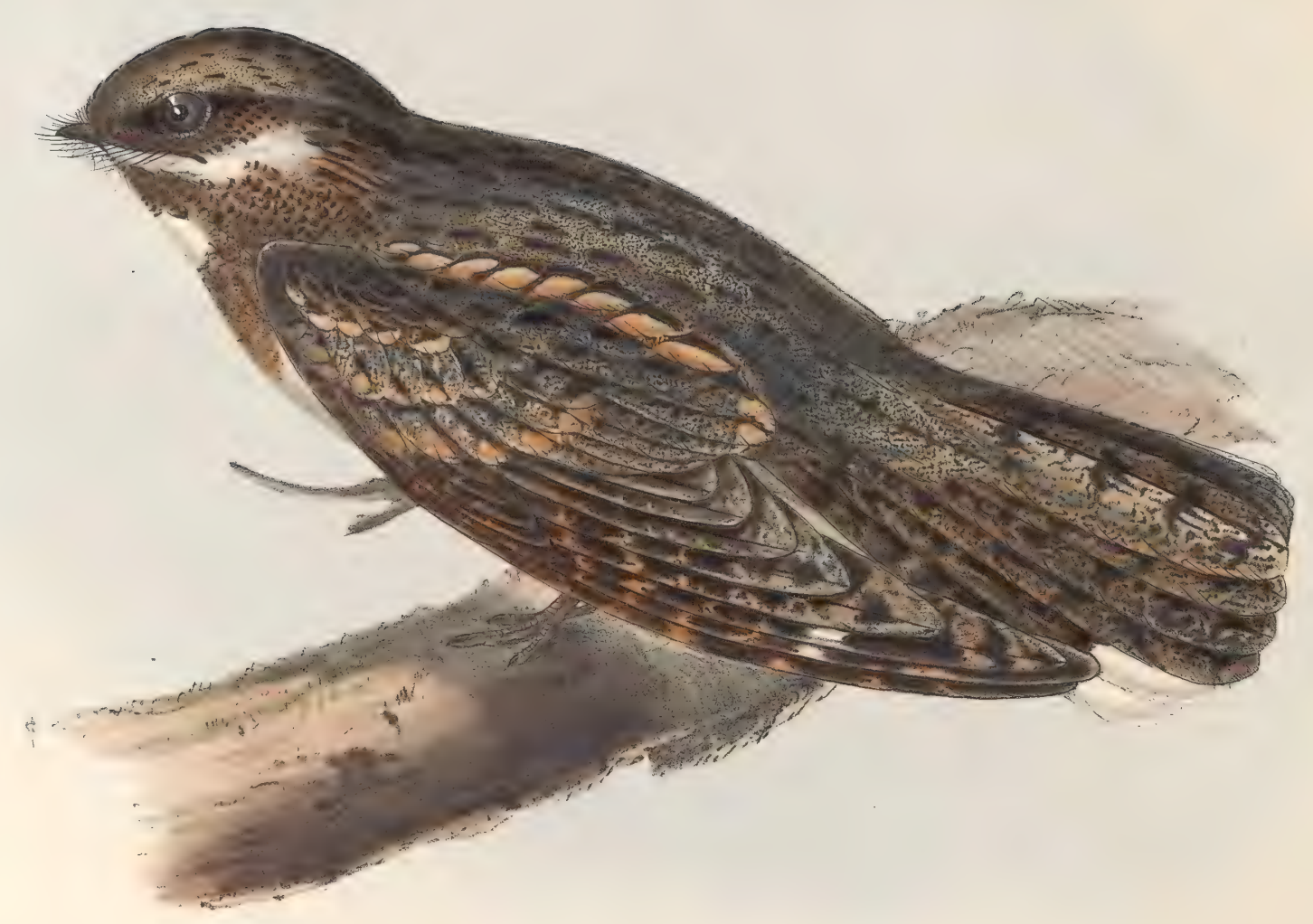

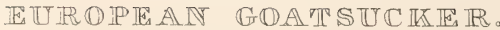

Caprimulgus Enropæus; (Linn:) 


\section{Genus CAPRIMULGUS, Linn.}

Gen. Char. Bill very short, weak, curved at the tip, broad and depressed at the base; the upper mandible deflected at the point; gape very large, and extending to or beyond the posterior angle of the eyes; basal edge of the upper mandible bordered with strong moveable bristles, directed forwards. Nostrils basal, tubular; or with a large prominent rim, clothed with very small feathers. Wings long, the first quill shorter than the second, which is the longest of all. Tail rounded or forked, of ten feathers. Tarsi short. Toes three before and one behind, the anterior ones united as far as the first joint by a membrane; the claw of the middle toe broad, and serrated on the inner edge.

\section{EUROPEA N G OA TSUCKER.}

Caprimulgus europæus, Linn.

L'Engoulevent ordinaire.

The Caprimulgus europeeus was until within the last few years the only species of this curious and interesting race of birds known to inhabit Europe; a second has, however, been discovered by M. Natterer in the South of Spain, and described by him under the name of Caprimulgus ruficollis, from the conspicuous red band which crosses the back of the neck, certainly a far more appropriate term than the one (europceus) given to the present bird, which is now applicable to both species, or to any others that may hereafter be discovered.

The European Goatsucker is a migratory bird, inhabiting all the temperate portions of Europe during summer, and retiring southward beyond the Mediterranean on the approach of winter. It arrives in the British Islands from the middle to the end of May, and departs again about the latter end of September or beginning of October. While here it is distributed over the whole of the kingdom, residing in woods, plantations, thick beds of fern, (whence its provincial name of Fern Owl,) and districts clothed with tall grasses. Being strictly nocturnal in its habits, it avoids as much as possible the bright light of day, but on the approach of twilight it may be seen hawking for Melolonthe, Phalcene, and other nocturnal insects.

The flight of the Goatsucker is rapid in the extreme while in pursuit of its prey, and is accompanied by a number of evolutions, similar to those of the Swallow, but which are, if possible, performed with still greater ease and facility.

It makes no nest, but lays two eggs on the bare ground, amongst fern, heath, or long grass, sometimes in woods or furze, but always near woods, in which it may conceal itself by day. The eggs are white, marbled with light brown and grey.

The Goatsucker reposes mostly on the ground; and when it perches on the limb of a tree, it is commonly along the branch, and not across it like other birds.

"The male," says Montagu, " makes a very singular noise during the period of incubation, not unlike the sound of a large spinning-wheel, and which it is observed to utter perched, with the head downwards; besides which it emits a sharp squeak, repeated as it flies."

The whole of the upper surface and the throat are of an ashy grey, numerously spotted and streaked with dark brown, and tinged with pale or yellowish brown; the head and back streaked longitudinally with black; beneath the base of the under mandible runs a stripe of white, which extends along each side of the head; in the centre of the throat a patch of white ; under surface yellowish brown, transversely barred with black; outer webs of the quills blotched with red brown, the three exterior feathers having a large white patch on the inner webs near their tips; tail irregularly marked with black, grey, and yellowish brown, two outer tail-feathers on each side deeply tipped with white; bill and irides dark brown; tarsi pale brown.

The female differs from the male only in being destitute of the white spots on the quill-feathers, and of the white tips of the lateral tail-feathers.

We have figured a male of the natural size. 




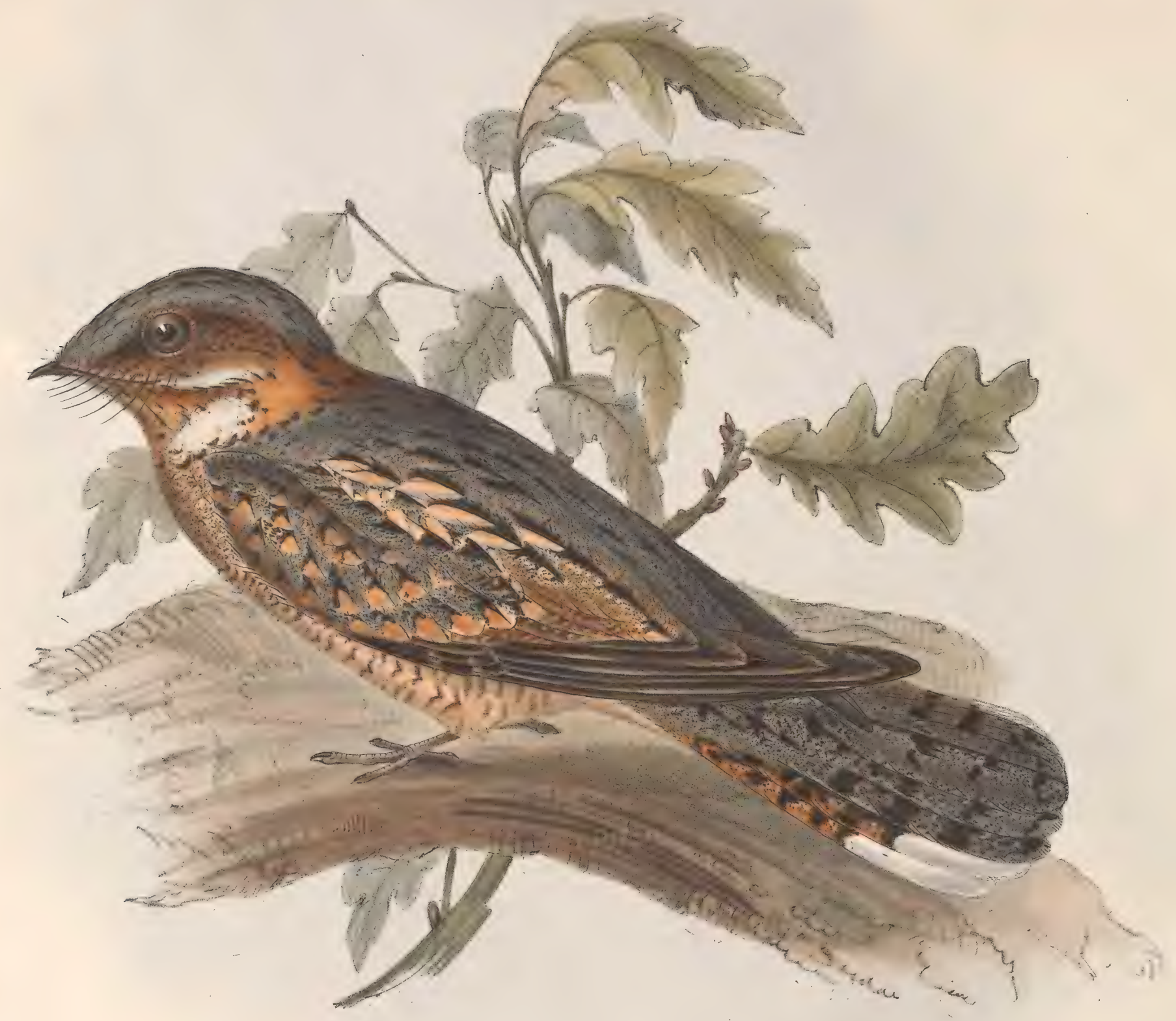

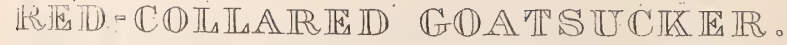

Caprimulgus ruficollis;(Termm: 


\title{
RED=COLLARED GOATSUCKER。
}

\author{
Caprimulgus ruficollis, Temm.
}

L'Engoulevent à collier roux.

Throvgr the kindness of Mr. John Natterer and the Directors of the Imperial Cabinet at Vienna, who have liberally forwarded the original specimen for our use, we are enabled to give a figure of this interesting species of Goatsucker, which is so extremely rare, that we know of no examples in the museums of this country, nor in any of those on the Continent, with the exception of Vienna. Northern Africa is, we doubt not, its natural habitat, whence it may occasionally pass into Europe, but so rarely that no other examples are on record than those referred to in the following notes, which accompanied the above-mentioned specimen, and which we prefer giving in M. Natterer's own words.

"Caprimulgus ruficollis : male. Shot the 14th of July, 1817, some miles distant from Algeziras, in the oakwoods by daylight. Iris dark brown; legs reddish grey; nostrils oval with their borders much elevated; length, 12 inches 8 lines; extent of the wings, $22 \frac{1}{2}$ inches; the tail exceeding the wings by $1 \frac{1}{2}$ inch.

"Another male was shot on the 20th of July in the valley of the Rio del Miel near Algeziras, flying very low, an hour after sunset. Length, 13 inches and 3 lines; extent of the wings, $23 \frac{1}{4}$ inches; the tail exceeding the wings by 1 inch and 8 lines.

"The female I shot while flying near the same spot on the 21 st of July. Length, 12 inches and 8 lines; extent of the wings, $22 \frac{1}{2}$ inches; the tail exceeding the wings by 2 inches. The female closely resembles the male, differing only in having less white on the throat; the white tips of the two outer tail-feathers only 8 lines long, and tinged with brown on the outer web; the white spots on the three first primary quills smaller and tinged with ochre, and without any corresponding mark on the outer web as in the male; the remainder of the plumage is exactly the same as that of the male.

"The name of the bird in the part of Spain where it was killed is Samala. It seems to be a very rare bird, for I passed several nights in the adjacent woods without discovering any more examples."

The male may be thus described:

Forehead, sides, and back of the head, back, and six centre tail-feathers ashy brown, with numerous extremely fine freckles of dark brown, which are most decided on the tail-feathers, where they assume the form of irregular bars; feathers on the centre of the head dark brown with paler edges freckled with a darker tint; throat, sides of the face, ear-coverts, and back of the neck rufous, which is very rich on the latter, where it forms a decided collar; from the angle of the mouth to the back of the neck passes a narrow line of white; on each side of the neck an irregular patch of white feathers with a crescent mark of deep brown at the tip; wing-coverts the same as the back, but having the tip of each feather rufous; scapularies dark brown, with a broad margin of buff on their outer edge, and with grey freckled with dark brown on the inner; primaries dull brown; with a broad white spot on the inner web, forming a bar on the under side of the wings and a faint indication of it on the outer web; the secondaries and the tips of the primaries, particularly on their inner webs, having irregular and faint markings of grey; two outer tail-feathers on each side dark brown, irregularly blotched on the outer web with reddish brown and largely tipped with white; all the under-surface pale rufous, with irregular transverse arrow-shaped markings of deep brown, which are most numerous on the breast; bill and feet reddish grey.

We have figured the male of the natural size. 




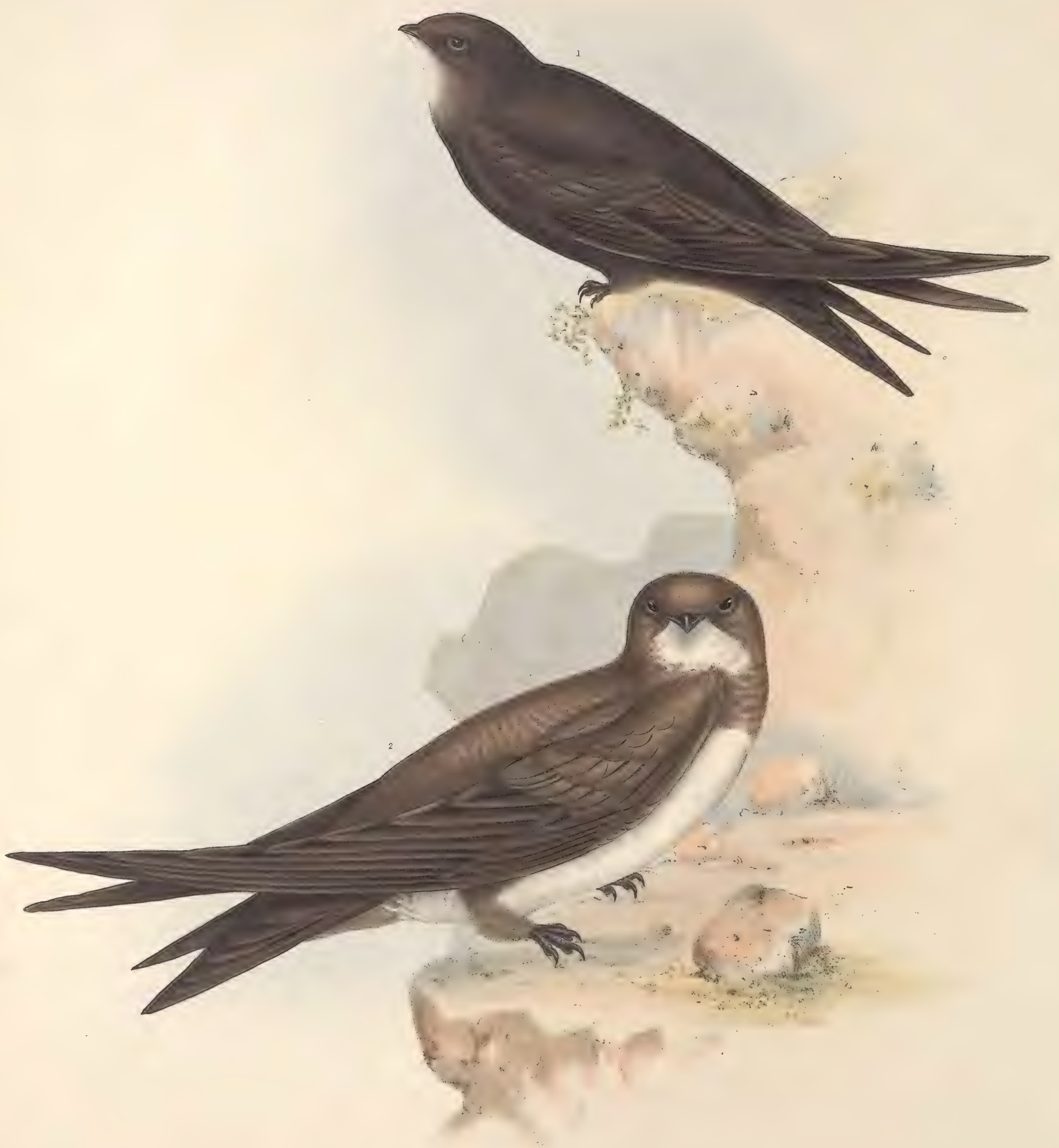

SWIT TIT

1. Cypselus murarius (Tomm:

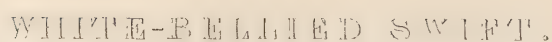

2. Crpselus. Vpimus / Temm 


\title{
Genus CYPSELUS, Illig.
}

GEN. Char. Beak very short, triangular, large, all its base concealed, depressed; gape extending beyond the eyes; upper mandible hooked at the point; nostrils longitudinal, near the ridge of the beak, open, the edges raised and furnished with small feathers. Tarsi very short. Toes four, all directed forwards and entirely divided; nails short, strong and hooked. Tail composed of ten feathers. Wings very long; the first quill-feather a little shorter than the second.

\section{S W I F T.}

Cypselus murarius, Temm.

Le Martinet.

WE know of no birds, and certainly none in Europe, possessed of equal power of flight with the species of the present genus : in fact, their natural habitat appears to be the air, their short feet and strong claws serving more especially to cling to the rough surface of rocks, towers, and high buildings, or firmly securing them while in a state of repose. Their extraordinary length of wing, combined with the shortness of their tarsi, prevents them walking on, or rising from, any level situation, unless by repeated exertions, or taking advantage of some slight elevation; they are therefore seldom, if ever, to be seen on the ground. These birds are distinguished not only by the velocity of their flight, but by the smooth and graceful sweeps they take during their aerial career in pursuit of the various insects constituting their food. In fine and serene weather, when these insect tribes ascend to an almost incredible elevation, the Swifts occupy the highest regions of the atmosphere, persevering in the chase almost beyond the reach of sight. Their degree of elevation, however, doubtless depends on that of the insects, and the latter on the influence of the weather; so that the low or high flight of these birds may be taken as a barometrical index of the state of the air, and the consequent probability of rain or the contrary.

The Swift, which is spread over Europe generally, is essentially migratory. It arrives in England at the beginning of May, and leaves us again as early as August or September. It breeds in old buildings, steeples, ruins, towers, and rocks. The eggs are white.

The colour of the plumage, with the exception of the throat, which is white, is of a uniform sooty-black with bronze-coloured reflections. The sexes offer no external marks of distinction.

\section{WHITE-BELIIED SWIFT.}

\author{
Cypselus alpinus, Temm. \\ Le Martinet à ventre blanc.
}

ThE claims of this fine Swift to a place in the Fauna of Great Britain rest on the circumstance of one noticed by Mr. Selby in the "Transactions of the Northumberland, Newcastle, and Durham Natural History Society;" and one we have personally inspected, which was killed by the gardener of R. Holford, Esq., on his estate at Kingsgate near Margate, in whose possession it now remains.

The natural habitat of the Cypsehus alpimus is more exclusively limited to the middle of the southern districts of Europe, particularly its alpine regions, and the shores of the Mediterranean, being very abundant at Gibraltar, Sardinia, Malta, and throughout the whole of the Archipelago; ; and to these may also be added the northern parts of Africa. In its manners it closely resembles our well-known Swift, but possesses, if possible, still greater powers of flight.

It would appear that the clefts of rocks and high buildings are the sites which this bird chooses for the purpose of nidification; the female laying three or four eggs of a uniform ivory white.

The sexes of this species present but little differences, the colour of the female being rather less decided; in the male a uniform greyish brown is spread over the whole of the upper surface, which descends across the breast in the form of a band, along the flanks and over the inferior tail-coverts ; the throat and the middle of the belly are of a pure white, the tarsi covered with brown feathers, and the irides brown. Length from nine to ten inches. 




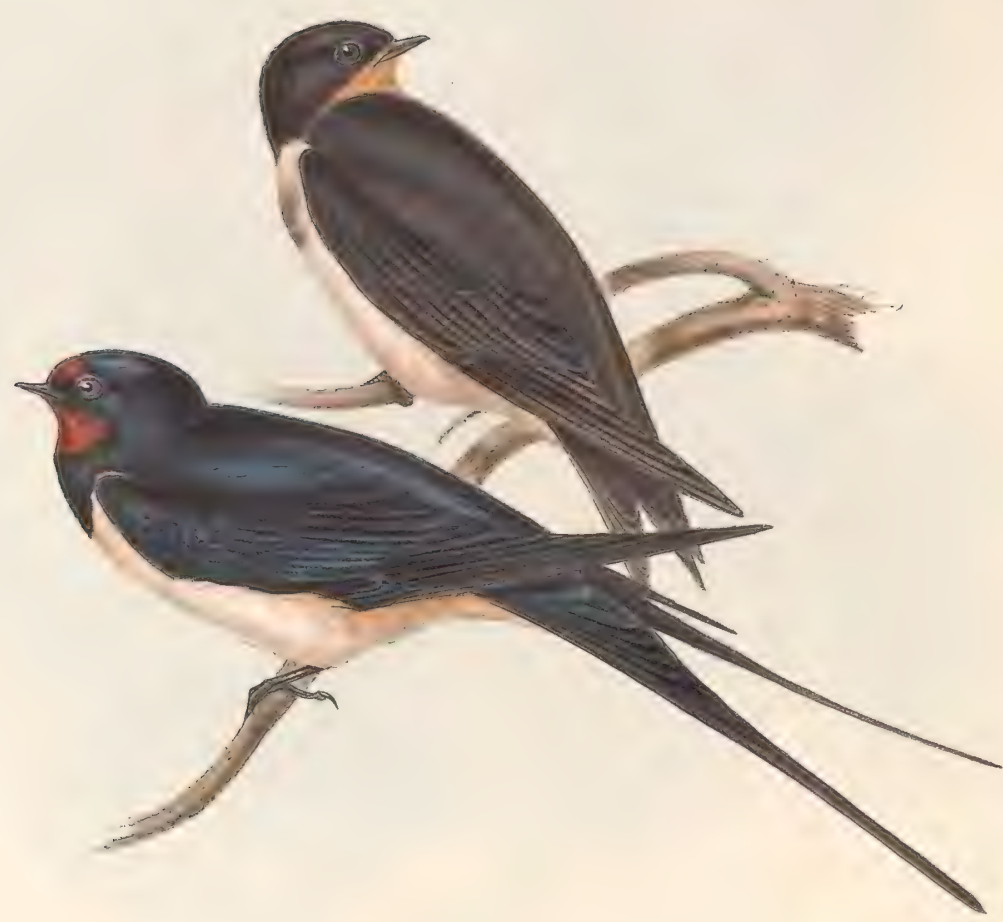

CHIDTNEY SWALIOW.

Hirundo rustica: (Limn) 


\title{
Genus HIRUNDO, Linn.
}

Gen. Char. Bill short, much depressed, wide at the base; upper mandible bent at the tip and carinated; the gape extending as far back as the eyes. Nostrils basal, oblong, partly covered by a membrane. Tarsi short. Toes slender, three before and one behind; the outer toe united to the middle one as far as the first joint. Tail of twelve feathers, generally forked. Wings long, acuminate, the first quill-feather the longest.

\section{CHIM E E SW A L L OW。}

\author{
Hirundo rustica, Limn.
}

L'Hirondelle de Cheminée ou domestique.

THE migration of the Swallow and the laws which regulate its movements are now so well understood that it will scarcely be necessary to advert to them here. In the British Islands and in all other portions of the European Continent, the period of its arrival may be calculated upon with tolerable certainty, a seattered few generally appearing in all parts of the same latitude from the fifth to the tenth of April, after which period their numbers become suddenly augmented, and the work of reproduction is almost immediately proceeded with. Two broods are generally produced in the course of the season, the first being mostly able to fly beforc midsummer, and the second in the month of August. The young on leaving the nest are assidnously supplied with food, and carefully attended by their parents, until they are sufficiently strong to provide for themselves. The task of incubation being accomplished, the Swallows congregate in extensive flocks, and in obedience to the laws of nature retrace their steps, and pass the remainder of the year in more southern countries, where the insect food so essential to their existence is ever abundant. In this migratory movement, the adults, we are inclined to believe, always precede their progeny, which remain with us as long as the weather continues open and a sufficient supply of insects can be obtained for their subsistence.

The members of this aërial tribe are only excelled in their power of flight by the Cypseli, or Swifts, and are seen to the greatest advantage in the air, where their dexterity in securing their prey, the manner in which they drink while passing over the stream, and the celerity with which they feed their young while on the wing, cannot fail to call forth our admiration.

It is now generally admitted that the Barn Swallow of America is quite distinct from the British species; consequently the range of our bird is limited to the Old World. In the summer months the Hirundo rustica is universally dispersed over the whole of Europe, whence, as before stated, it migrates periodically into tropical regions; and as all migratory animals move from north to south, and vice vers $\hat{\theta}$, Africa constitutes its winter residence.

In the British Islands the sites chosen for its nests are the interiors of chimneys and of coal-pits; but in many parts of the Continent, where these situations are not frequently met with, it builds on church torvers, old ruins, the eaves of houses, barns, and other outbuildings. The eggs are four or five in number, their colour white, speckled with reddish brown and pale blue.

Forehead and throat rich chestnut; the remainder of the head, a band across the breast, and the whole of the upper surface black with blue reflections; tail very deeply forked, the two outer feathers extending far beyond the others; a large white spot on the inner webs of all the feathers, except the two middle ones; all the under surface white tinged with reddish brown, which is deepest on the vent and under tail-coverts; bill and feet black.

The female has rather less of the rich chestnut on the forehead, the black is less brilliant, and the outer tail-feathers much shorter than in the male.

The young is entirely destitute of the chestnut on the forehead, the throat is merely tinged with rufous; the band across the breast is but faintly indicated; all the upper surface resembles that of the adult, but the tints are much more dull; the wings are also shorter, and it is destitute of the long tail-feathers, which are not acquired till the first moult.

Our Plate represents an adult and a young bird of the natural size. 




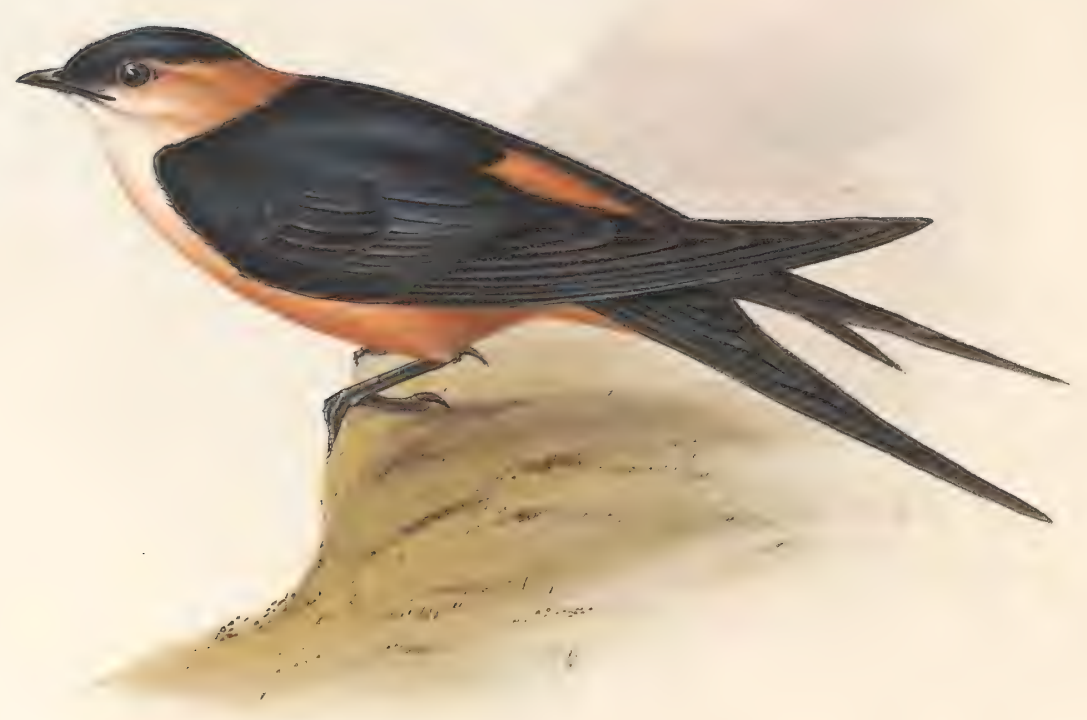

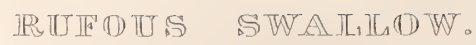

Hirundo rufula; ('Temm) 


\section{RUFOUS SWALLOW.}

Hirundo rufula, Temm.

L'Hirondelle rousseline.

Although Africa, particularly the southern and western portions of that continent, constitutes the native habitat of this beautiful species of Swallow, the contiguous portions of Europe are not without its occasional presence, and notwithstanding it is now considered a portion of the Fauna of this quarter of the globe, still we do not believe it occurs at regular periods, as is the case with the Hirundo rustica, but that it occasionally strays across the Mediterranean from the northern coasts of Africa, where it is also a rare species.

In Le Vaillant's 'Oiseaux d'Afrique' will be found an interesting account of this species, from which we learn that it is so familiar that it readily enters the houses of the inhabitants, particularly those in the interior, frequently building its nest in the sleeping-room of the family; that the nest differs from those of the other species of the genus, being a hollow ball, the entrance to which is constructed in the form of a long tube, through which the female passes into the interior, which is lined with any loose and soft materials the bird may find at hand. The eggs, which are from four to six in number, are white sprinkled with small brown spots.

Like the other members of the genus, its food consists of insects and their larva.

The top of the head, occiput, back, and wing-coverts are black with steel blue reflexions; the remainder of the wings and tail brownish black, with a faint indication of steel blue colour; back of the neck, rump, and upper tail-coverts deep rufous; sides of the face and throat pale rufous, which colour gradually becomes deeper and richer on the under-surface, flanks, and under tail-coverts; beak, irides, and feet black.

The female resembles the male, except that the crown of the head is rust red instead of black, and the tailfeathers are not so long.

We have figured an adult male of the natural size. 




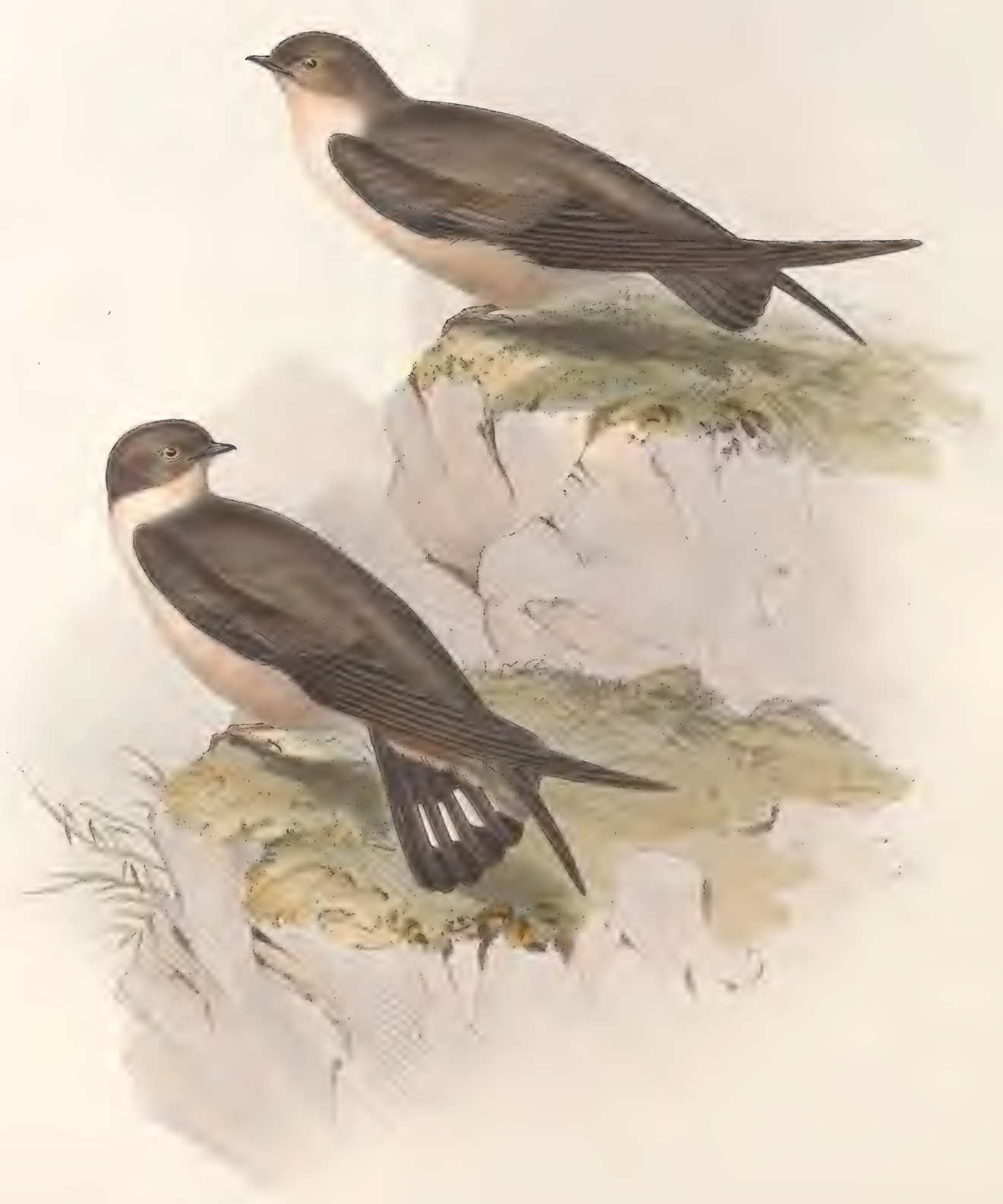

$\mathbb{R} \mathbb{C} \mathbb{C} \mathbb{R}$ MAR $\mathbb{R} \mathbb{I} \mathbb{N}$.

Hirundo rupestris,(Linn) 


\title{
R O C K M A R T I N.
}

\author{
Hirundo rupestris, Linn.
}

L'Hirundelle de Rocher.

THrs bird is very abundant along the shores of the Mediterranean, and occurs also in such portions of Southern Europe as abound in rocky and precipitous places : it is an inhabitant of Savoy and Piedmont, but is more scarce in Switzerland, Germany, and the middle of France. As far as we are aware, it has never been found in the northern parts of Europe, nor has it as yet been observed in the British Isles. It is larger than the Common Sand Martin, to which species it bears a close resèmblance both in the colouring of its plumage and also in its general economy. It builds its nest and rears its young in the holes of rocks; the eggs being five or six in number, white, marked with minute dots.

We need hardly observe that its general habits and manners are in strict accordance with those of its family. Its food consists of insects, which it takes during flight.

The sexes offer no distinguishable difference in the markings of their plumage.

The whole of the upper surface is a uniform light brown; the quills and tail-feathers being darker, the inner webs of all the feathers of the latter, except the two middle ones, having in their centre a large oval blotch of white; the under surface is of a dull sandy white, slightly tinged with rufous.

We have figured a male and female of the natural size. 


A 


\title{
MA R T I .
}

\author{
Hirundo urbica, Linn.
}

L’Hirondelle de fenêtre.

Like the Swallow this little fairy-like bird is strictly migratory, resorting during our winters to climes far to the south of the British Islands, and indeed to any other portion of Europe; whence it does not return till the spring, generally making its appearance about the middle of April : but in this respect the Martin, as well as most other insectivorous birds, is influenced in a great measure by the state of the season, a certain degree of temperature being necessary for bringing forth the insects upon which its existence depends.

The flight of the Martin is not so rapid, nor attended with such sudden evolutions as that of the graceful Swallow, but it is nevertheless performed with great ease and buoyancy; and although it does not possess so long a wing in proportion to its size as any other of its European brethren, and is consequently less adapted for continued flight, still it is seldom if ever seen, resting either on trees or on the ground, but is continually traversing the air with apparently untiring wings, except during the period of nidification, when it descends to the earth for the purpose of collecting mud employed for the construction of its nest, which is erected under the eaves of houses and windows, the sides of rocks, under the arches of bridges, \&c. : the nest when complete is a most compact and solid structure, firmly cemented together, the labour of one day being allowed to remain until the substance has got hard and dry, before the little mason proceeds to heap on more wet materials; the only means of ingress or egress is a small hole on the most sheltered side of the nest: the interior is well lined with straw, hay, and feathers. The eggs are five in number, of a pinkish white. At first the young birds are fed in the nest, afterwards the parents cling to the outside by means of their claws, and feed them at the entrance; when able to fly, they are fed on the wing for a considerable time, like the Swallow, and they occasionally resort to the house-top, or to the branches of some neighbouring tree, where they are also supplied with food by their parents, until they have acquired sufficient strength and confidence to launch forth and provide for themselves.

Like the Swallow, the Martin produces two broods in the year, the first of which are able to fly in July, and the second in August or the beginning of September. Early in October the Martins assemble in large flocks, frequently so numerous as almost to cover the roofs of houses, particularly in the villages situated on the borders of the Thames. About the middle of the month they commence their migration, continuing to depart in flocks till the early part of November, after the sixth or eighth of which month few are to be seen.

The notes of its song, which is frequently uttered during the period of incubation, are guttural, but soft and pleasing.

The female differs but little from the male: the young during the first autumn are readily distinguished by the less degree of brilliancy in their colouring.

The head, back of the neck, and back glossy bluish black; wings and tail brownish black; rump and all the under surface pure white; bill black; tarsi and toes clothed with white downy feathers.

We have figured an adult male and female of the natural size. 




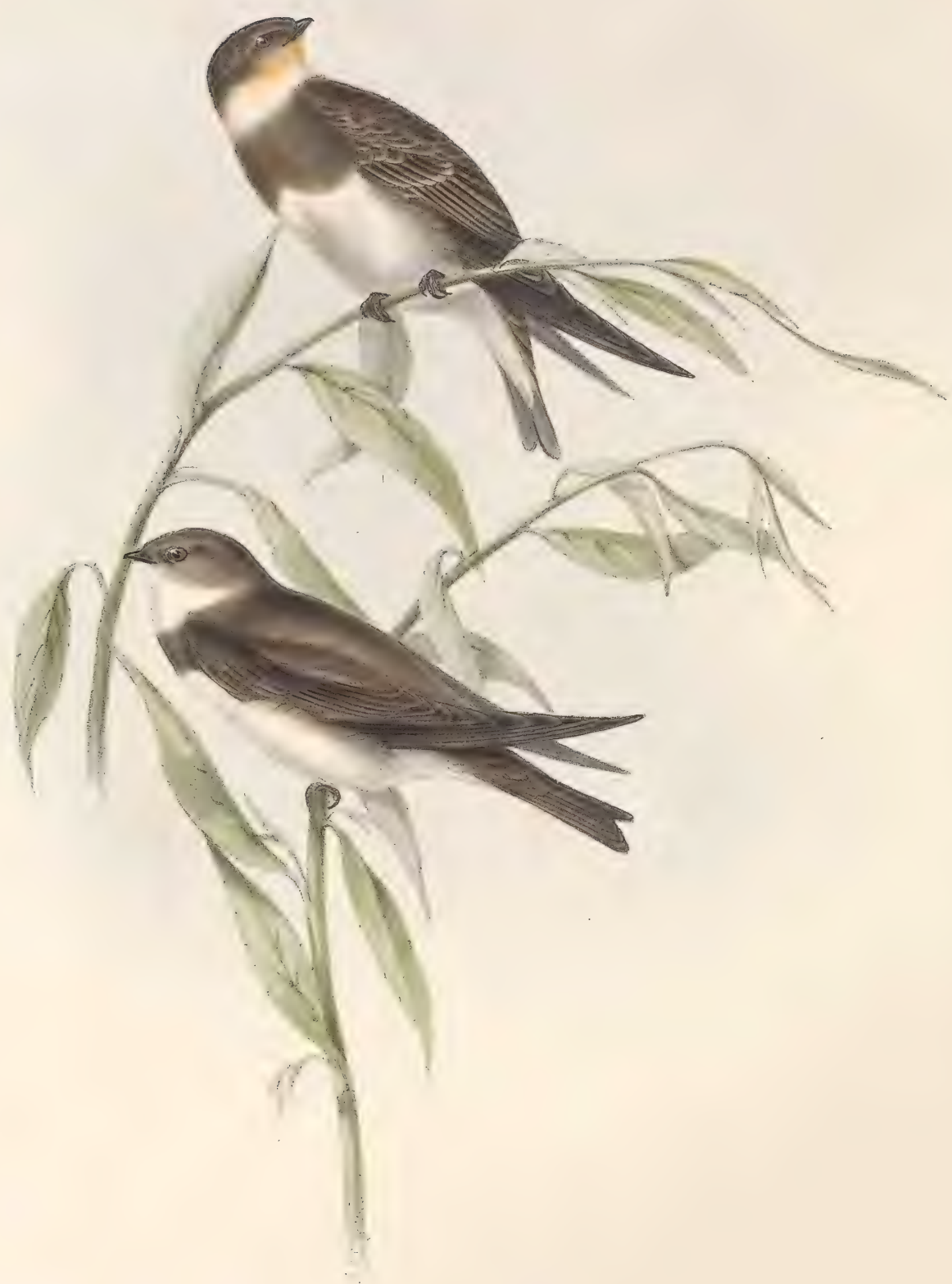

$S A \mathbb{N} \mathbb{N} \mathbb{N} A \mathbb{R} \mathbb{T} \mathbb{N}$ 。

Hirundo riparia, (Linn) 


\title{
SA N D M A RTIN.
}

\author{
Hirundo riparia, Linn.
}

L'Hirondelle de rivage.

W ттн the exception of the place chosen for the purpose of incubation, the Sand Martin resembles its congeners; but in this respect the whole tribe of which this delicate species forms a part, are singularly different, both as regards the form of their nests and the situations chosen for their reception: for instance, if we examine the four species which take up their summer residence in the British Islands, we find that the Swift is directed to ruins, particularly inaccessible towers, and large public buildings; the Swallow gives preference to the entrances of chimneys and the mouths of pits; while the little Fairy Martin adheres its hard clay nest to the sides of our dwellings, as if to court our protection and care; and the delicate little bird which forms the subject of the present plate is directed by the impulse of nature to nidify in places remarkably different from either of these, viz., steep and precipitous sand-banks, pits of chalk, \&c., more particularly the former, appearing to give a preference to banks overhanging water, though we have occasionally observed their breeding-places far remote from any water. In the most inaccessible parts of these situations this little excavator digs a horizontal hole of considerable depth, sometimes even to three or four feet, at the far end of which it places a nest, loosely constructed of dried grass and feathers, in which are deposited four or-five delicate eggs, of a clear white. As soon as the young gain sufficient strength, they reach the edge of their subterraneous passage, and at an early period wing their way after their parents, who soon teach them to capture insects for themselves and become independent of their assistance.

The task of reproduction being performed, the Sand Martin congregates in flocks, which are greatly augmented by the end of autumn, at which period the multitude assembled almost surpasses belief. The naturalist cannot look upon the vast herd of these little birds which collect to roost in the osier-beds on the banks of the Thames before their final departure, without admiring the design of an all-wise Creator in protecting these humble creatures during the period above alluded to, as by their means alone are kept in subjection the vast myriads of insects, which would otherwise become so numerous as to defy the power of man, with all his ingenuity, either to annihilate, or to work any apparent diminution of their numbers.

We have often observed the Sand Martin as early as the month of March, from which circumstance it must be ranked among the earliest of our summer visitors. There are few birds that have a more extensive range, being common throughout Europe, the continent of Africa, some portions of India, and, if we mistake not, it is spread over a great portion of the American continent.

It feeds exclusively on flies, which it captures on the wing, being endowed with powers of flight equal to any other species of the genus.

The sexes are alike in plumage, and the young of the year resemble the adults, except that the feathers of the upper parts are edged with a lighter margin.

The top of the head, upper surface, the body, and tail dark brown; throat, belly, and under tail-coverts white; primaries, bill, and feet blackish brown.

The young of the year have the same colouring as the adult, except that each feather on the upper surface is bordered with yellowish white.

We have figured an adult, and a young bird of the year, of the natural size. 




$$
2
$$




\title{
Genus MEROPS.
}

GeN. Char. Beak elongated, pointed, quadrangular, slightly arched, the ridge elevated. Nostrits basal, lateral, ovoid, open, slightly covered by hair directed forward. Tarsi short. Toes three before and one behind; the second toe united to the middle one as far as the second articulation, and the middle to to the inner one as far as the first articulation; the hind toe large at its base, with a very small claw; the second quill-feather the longest, the first very short.

\section{B EE - E A T E R.}

\author{
Merops apiaster, Linn \\ Le Guepier vulgaire.
}

THE station which the species of this genus occupy appears to be intermediate between the Kingsfishers on the one hand, and the Swallows on the other : to the former they are allied by their elongated form of beak, shortness of tarsi, brilliancy of plumage, similarity of places of nidification, and the white colour of the eggs; and to the latter by their gregarious habits, their lengthened wing, their great and continuous powers of flight, and their manner of capturing while on wing the insects which constitute their food.

The present beautiful species is we believe the only one of its genus which Europe can claim as its own.

It is a bird of migratory habits, visiting, in the greatest abundance, the warmer portions of the Continent, especially Italy, Spain, Sicily, the Archipelago, and Turkey; and, not unfrequently, France, Germany and Switzerland, straying at uncertain intervals across the Channel to the shores of England, sometimes singly, and sometimes in small flocks of eight, ten, or even twenty, but never remaining with us or attempting to breed, our climate being in all respects uncongenial to its habits. Montague informs us that it is nowhere so plentiful as in the southern parts of Russia, particularly about the rivers Don and Volga.

In the situation it chooses for a place of nidification, it greatly resembles our Sand-Martins, preferring precipitous sand-banks and the edges of rivers, in which it scoops out deep holes, generally in an oblique direction.

The eggs are from five to seven in number, of a pure white ; but whether deposited on the bare ground or in a nest we are not able to say with any degree of certainty, as it is a point on which different authors hold contradictory opinions.

In its manners it very much resembles the Swallow tribec, ontinuing like them for a length of time on the wing, and traversing backwards and forwards in pursuit of its food, which consists of flies, gnats, and small coleoptera, as well as bees and wasps, to which it is peculiarly partial, and from which it derives its name. Although its flight is, as above stated, like that of the Swallow, still we are informed its allied species in India are frequently in the habit of taking their food like the Flycatchers, whose manners they closely imitate, sitting motionless on a branch, darting at the insects as they pass, and returning again to their station. We have some grounds for suspecting that this peculiarity obtains more or less with all the species of this genus.

The sexes of the Bee-eater in general offer no material differences of plumage, except perhaps that the colours of the female are rather more obscure,- - circumstance which, as in the Kingsfisher, extends also to the young, the adult colouring of the plumage being assumed at an early age.

The beak is black, and one inch and three quarters in length; the irides red; the forehead yellowish white merging into blueish green; the occiput, back of the neck, and upper part of the back rich chestnut, fading off on the rump into a brownish amber; from the base of the beak proceeds a black mark which passes beneath the eye, and spreads over the coverts of the ear; the wings, except a large middle stripe of brown, are greenish, with something of an olive tinge; the quill-feathers inclining to blue and ending in black; the tail greenish; the chin and throat bright yellow, bounded by a black line which ascending reaches the earcoverts; the breast and whole of the under surface blue, intermingled with reflections of green; the first quill-feather rudimentary, the second the longest.

The tail is square with the exception of the two middle feathers, which are an inch longer than the others; feet and tarsi reddish brown. Total length from ten to eleven inches.

We have represented an adult male in its finest state of plumage. 




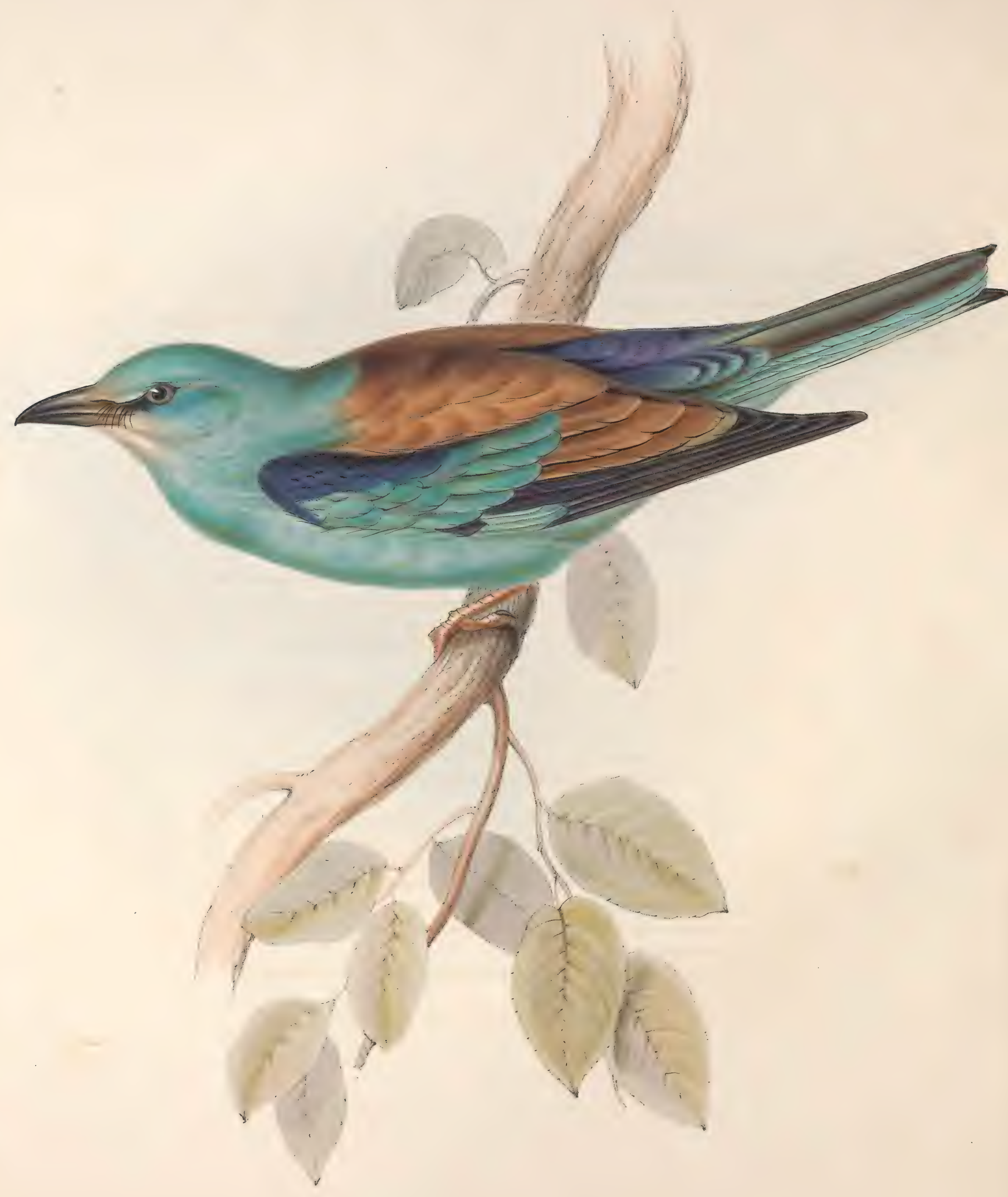

$\mathbb{R} \mathbb{D} I \mathbb{E}$ 。

Coracias garrula: (Limn) 


\section{Genus CORACIAS.}

Gen. Char. Beak moderate, compressed, higher than broad, straight, cutting; upper mandible curved towards the point. Nostrils basal, lateral, linear, pierced diagonally, partly closed by a membrane furnished with feathers. Feet, tarsus shorter than the middle toe, three toes before and one behind, entirely divided. Wings long, first primary a little shorter than the second which is the longest.

\section{ROLLER.}

Coracias garrulus, Linn.

Le Rollier vulgaire.

THE Roller is one of the most beautiful of birds, and although the extraordinary brilliancy of its plumage, varying in an assemblage of the finest shades of blue and green, as well as its great rarity, might render its claim to a place in our Fauna doubtful in the minds of some of our readers to whom the species is but little known, so many instances of its occurrence in this country will be found recorded by various authors, that it is our pleasant duty to consider it British as well as European.

This handsome bird is said to be common in the oak forests of Germany, and also in many of those of Denmark and Sweden. It is less plentiful in France, and according to M. Temminck is never seen in Holland. Its capture in this country has generally happened along the extended line of our eastern coast, from Norfolk northwards. Frequenting large woods generally, it builds in the holes of decayed trees, and lays from four to seven eggs of a smooth and shining white, in form a short oval almost round, very like those of our Kingfisher, but much larger.

The whole length of this bird is about twelve inches; the bill is black towards the point, becoming brown at the base, with a few bristles ; irides of two circles, yellow and brown; head, neck, breast and belly various shades of verditer blue, changing to pale green; shoulders azure blue; back reddish brown; rump purple; wing primaries dark blueish black, edged lighter; tail-feathers pale greenish blue, the outer ones tipped with black, those in the middle are also much darker in colour; legs reddish brown. In old males the outer tailfeathers are somewhat elongated. Adult females differ but little from the males, but young birds do not attain their brilliant colours till the second year.

Their food consists of worms, snails and insects generally, and in their habits these birds are remarkably noisy and restless.

Our figure is of the natural size, and was taken from a fine adult male. 




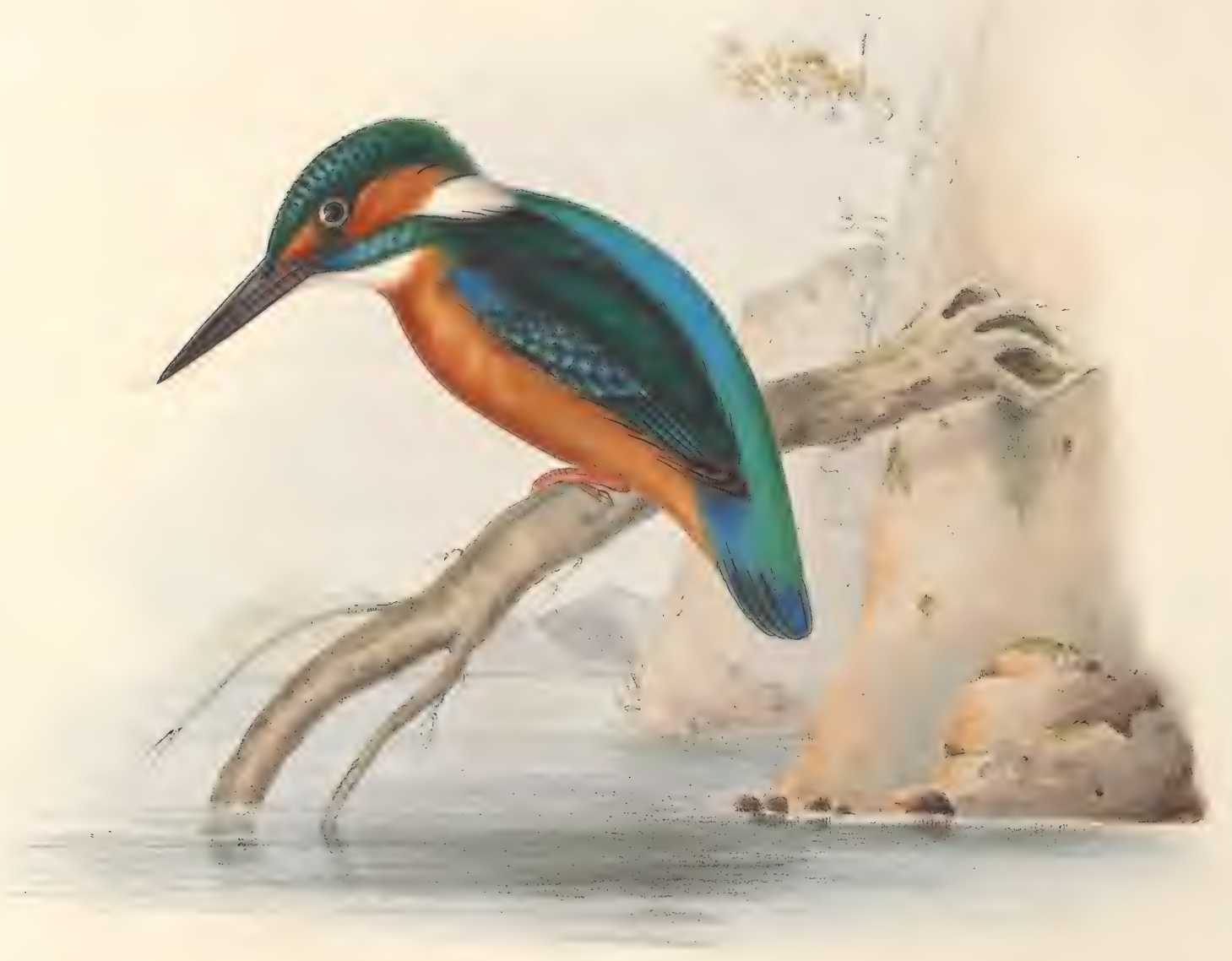

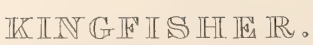

Alcedo ispida, (Linn). 


\title{
Genus ALCEDO.
}

GEN. Char. Beak long, straight, quadrangular, and acute. Nostrils placed at the base of the beak, oblique, and nearly closed by a naked membrane. Feet small ; tarsi short, naked. Toes three before, of which the external toe is united to the middle one as far as the second articulation, and the middle toe to the inner one as far as the first; hind toe large at its junction with the tarsus. Third quill-feather the longest.

\section{KIN GSFISHER.}

\author{
Alcedo ispida, Linn.
}

Martin pêcheur.

WHEN we behold the brilliant colours of this bird as it darts by us like a meteor, displaying the metallic lustre of its plumage, we cannot help fancying for the moment that we behold some erratic native of a tropical clime.

The appetite of the Kingsfisher is voracious, and his manners shy and retiring: dwelling near lonely and sequestered brooks and rivers, he sits for hours together motionless and solitary on some branch overhanging the stream, patiently watching the motions of the smaller fishes which constitute his food; waiting for a favourable moment to dart with the velocity of an arrow upon the first that is near enough the surface or within the reach of his aim, seldom failing in the attempt. He then returns to his former station on some large stone or branch, where he commences the destruction of his captive, which is effected by shifting its position in his bill, so as to grasp it firmly near the tail, and then striking its head smartly against the object on which he rests: he now reverses its position, and swallows it head foremost; the indigestible parts are afterwards ejected in a manner analogous to that of the Owls and birds of prey.

The Kingsfisher, however, does not confine himself entirely to this mode of watching in motionless solitude; but should the stream be broad, or no favourable station for espionage present itself, he may be seen poising himself over it at an altitude of ten or fifteen feet, scrutinizing the element below for his food,--plunging upon it with a velocity which often carries him considerably below the surface. For these habits his muscular wedge-shaped body, increasing gradually from a long pointed bill, aided by the sleek metal-like surface of the plumage, which at the same time freely passes throngh and throws off the water, seems expressly to adapt him.

The wing of the Kingsfisher is short but powerful; hence its flight is smooth, even, and exceedingly rapid.

Silent except during the pairing and breeding season, (when he occasionally utters a sharp piercing cry, indicative perhaps of attachment,) and equally solitary and unsocial in his habits, the Kingsfisher dwells alone, seldom consorting with others, or even with his mate, except in the period of incubation and during the rearing of the young, when their joint labours are necessary, and both unite with great assiduity in the office of procuring the requisite supplies of food. The places selected for this purpose are steep and secluded banks overhanging ponds or rivers, where in a hole, generally at a considerable distance above the surface of the water, and extending to the depth of two or three feet into the bank, the female, without making a nest, lays five or six eggs of a beautiful pinky white. As soon as the young are hatched, the parent birds may be seen incessantly passing to and from the hole with food, the ejected exuviæ of which in a short time form around the unfledged brood a putrid and offensive mass.

The young do not leave the hole until fully fledged and capable of flight; when, seated on some neighbouring branch, they may be known by their clamorous twittering, greeting their parents as they pass, from whom they impatiently expect their supplies. In a short time, however, they commence plundering for themselves, assuming at that early age nearly the adult plumage. The Alcedo ispida is the only species of the genus found in Europe, the western parts of which, including the British Isles, seem to be its proper habitat. The young appear to possess habits of partial migration, at least in our British Islands, wandering from the interior parts along the courses of rivers to the coast, frequenting, in the autumnal and winter months, the mouths of small rivulets and dykes near the sea; but more particularly those along the line of the southern coast and the shores of adjacent inlets.

The annexed Plate represents a male, between which and the female there is no distinguishing difference of plumage. The bill is black; irides dark; the crown of the head, cheeks, and wing-coverts, of a deep shining green, each feather tipt with a lighter metallic hue; the rest of the upper surface, a brilliant azure; the ear-feathers rufous, behind which a white spot extends to the nape of the neck. The throat white, the under surface fine rufous; the legs bright orange.

Length seven inches; weight from two ounces to two and a half. 




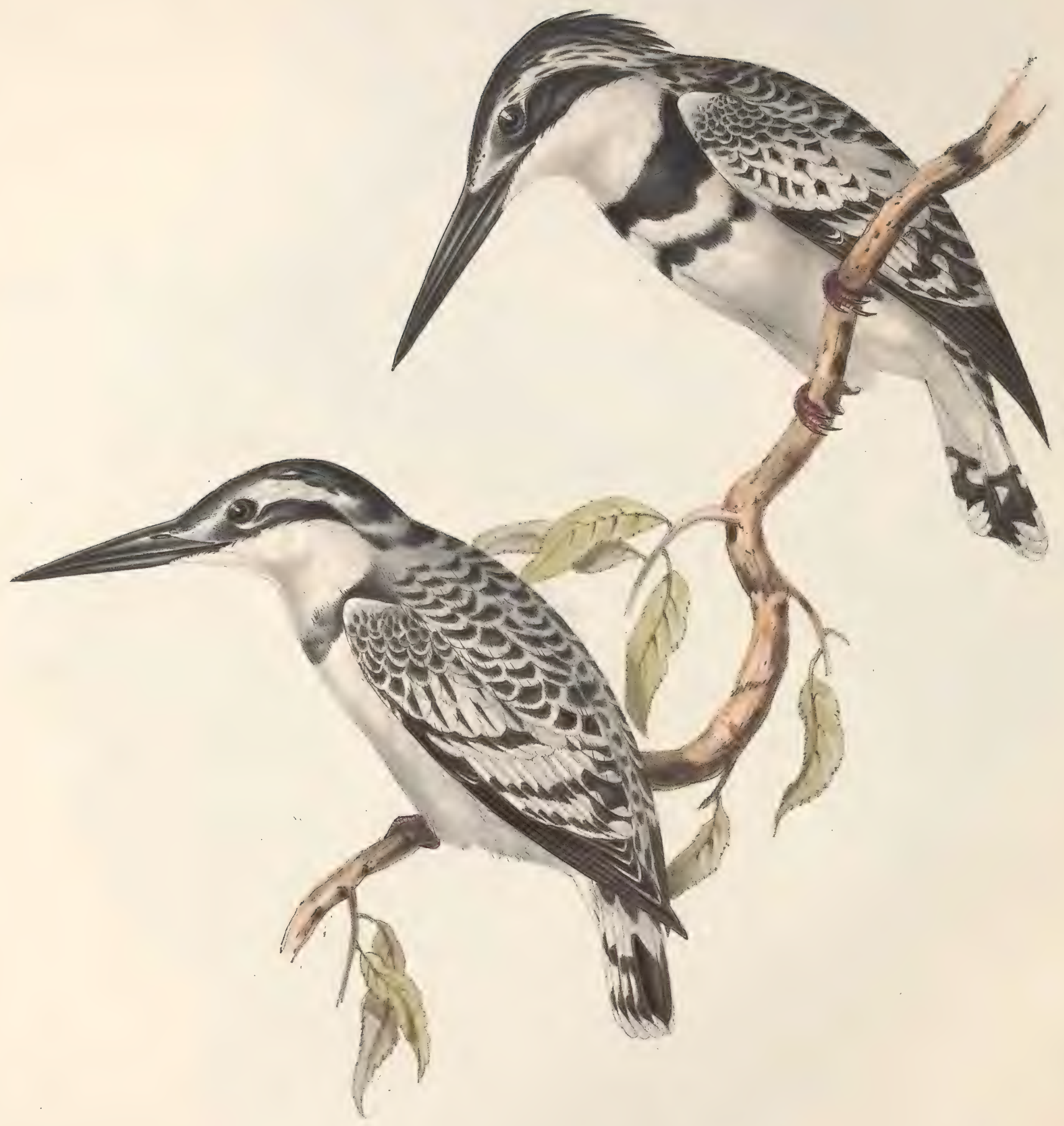

BIIACIK AND TVHITE IXINGFISHER。

Acedo rudis; (7inze) 


\title{
BLACK A D WHITE KINGSFISHER。
}

\author{
Alcedo rudis, Linn.
}

Le Martin Pêcheur Pie.

\begin{abstract}
Aztнougr the continents of Africa and Asia constitute the natural habitat of this species, still from its occurrence in some of the islands of the Grecian Archipelago, it is necessarily added to the Fauna of Europe, although it is but a rare and accidental visitor. It is abundantly dispersed over the whole of Africa, particularly on the banks of the Nile and the other rivers of Egypt, as also those of Syria and the adjacent countries. The discovery of this Kingsfisher in a quarter of the globe where until lately only a single species had been found, renders it a bird of great interest, and we regret that we cannot lay before our readers any authentic information relative to its peculiar habits and manners. In the third part of his "Manuel" M. Temminck merely states that it feeds on fishes, and lays white eggs. In the form of its bill and in its general structure, it so nearly resembles the Alcedo ispida, that although differing from it in size and in the character of its plumage, we may reasonably suppose its general economy to be in strict accordance with that species.

As is the case with most species of its tribe, the plumage of the sexes is very similar ; the female and young, however, appear to have the chest crossed with a somewhat narrow and single band of white, while the male has two bands, the upper one of which becomes very broad towards the shoulders, and gradually diminishes towards the middle of the chest; in other respects they are so similar that one description will be sufficient.

Crown of the head and occiput black; the whole of the upper surface varied with numerous bars of black and white, the latter colour terminating and bordering all the feathers; a black band extends from the angle of the beak and spreads over the ears; all the under parts white except the bands of black, which extend across the chest; primaries black; tail white at the base, the remainder barred with black and white; bill black; feet reddish brown.
\end{abstract}

The Plate represents a male and female of the natural size. 





\title{
PIED FL Y CA T CHER.
}

\author{
Muscicapa luctuosa, Temm \\ Le Gobe-mouche becfigue.
}

IN the British Isles this interesting little bird is exceedingly local in the districts it chooses for its periodical visits. Arriving, on the return of spring, from the more congenial and warmer portions of the Old Continent, it takes up its abode, not, as might be expected, in the southern parts of our island, but in the northern and midland counties, especially Lancashire, Yorkshire and Derbyshire, finding probably either food or some other inducement, of which we have no knowledge, that is suited to its wants. In France and Germany it is far from being scarce; but its most favourite tract is along the European shores of the Mediterranean, and over the whole of Italy. In Holland, and, we believe, in Denmark, Sweden and Russia, it is never seen.

The Pied Flycatcher is a most active and unwearied pursuer of the insect tribes, being continually in motion, darting at them as they pass, or searching after them among leaves and flowers. Whether it be for the sake of the fruit itself, or for the insects which abound near the figs, certain it is, that from the circumstance of the bird being constantly found in the neighbourhood of fig trees, it has obtained the name of Beccafico. It constructs a nest in the holes of trees, and lays from four to six eggs, of a uniform pale blue colour.

\section{WHITE-COLLARED FLYCATCHER.}

\author{
Muscicapa albicollis, Temm. \\ Le Gobe-mouche à collier.
}

Althovgh we have seen this species in a collection of British birds, and were informed that it was supposed to have been killed in England, still we have every reason to believe that it seldom advances so far north as England, or even the adjacent provinces of France or Germany; it is in fact more strictly confined to the central portion and Asiatic confines of Europe.

As regards the distinguishing characteristics of these two closely allied species, we may observe, that the adults in the plumage of summer may be easily distinguished from each other by the absence in the former of the entire collar round the neck; but to render the description of both these species more complete, we beg leave to translate the following passage from the valuable Manuel d'Ornithologie of M. Temminck: "The female of the two species, the males in their winter clothing, and the young, all resemble each other so closely as frequently to deceive. They may be easily distinguished, except in the first species, by the little white speculum which occupies the centre of the wing in M. albicollis, whilst the wing is of one colour in M. luctuosa; secondly, by the lateral feathers of the tail, of which the two external hare the edge whitish, more or less spread, according to age, in M. albicollis, whilst in the M. luctuosa the three lateral tail-feathers are slightly bordered with white edges. The manner of living, the note or call, and the song of the male offer very marked differences : the eggs also differ in colour. It is to M. Lotinguer that we are indebted for the knowledge of the double moult which annually takes place in these birds."

In winter, according to the above-quoted author, both these species lose the black plumage of summer, and assume a uniform brown livery over all the upper parts, at which season the young, female and males, resemble each other: on the return of spring they moult again, the males assuming their black livery.

In the month of October, and during the greater part of the winter, both these species collect in countless flocks in Italy, where they are known by the common term of Beccafici, and at which time they are taken in immense numbers for the table, being considered an especial luxury.

The eggs of M. albicollis are greenish blue spotted with brown.

The Plate represents a male and female of M. luctuosa, and a male of $M$. albicollis, of the natural size, in the plumage of summer. 




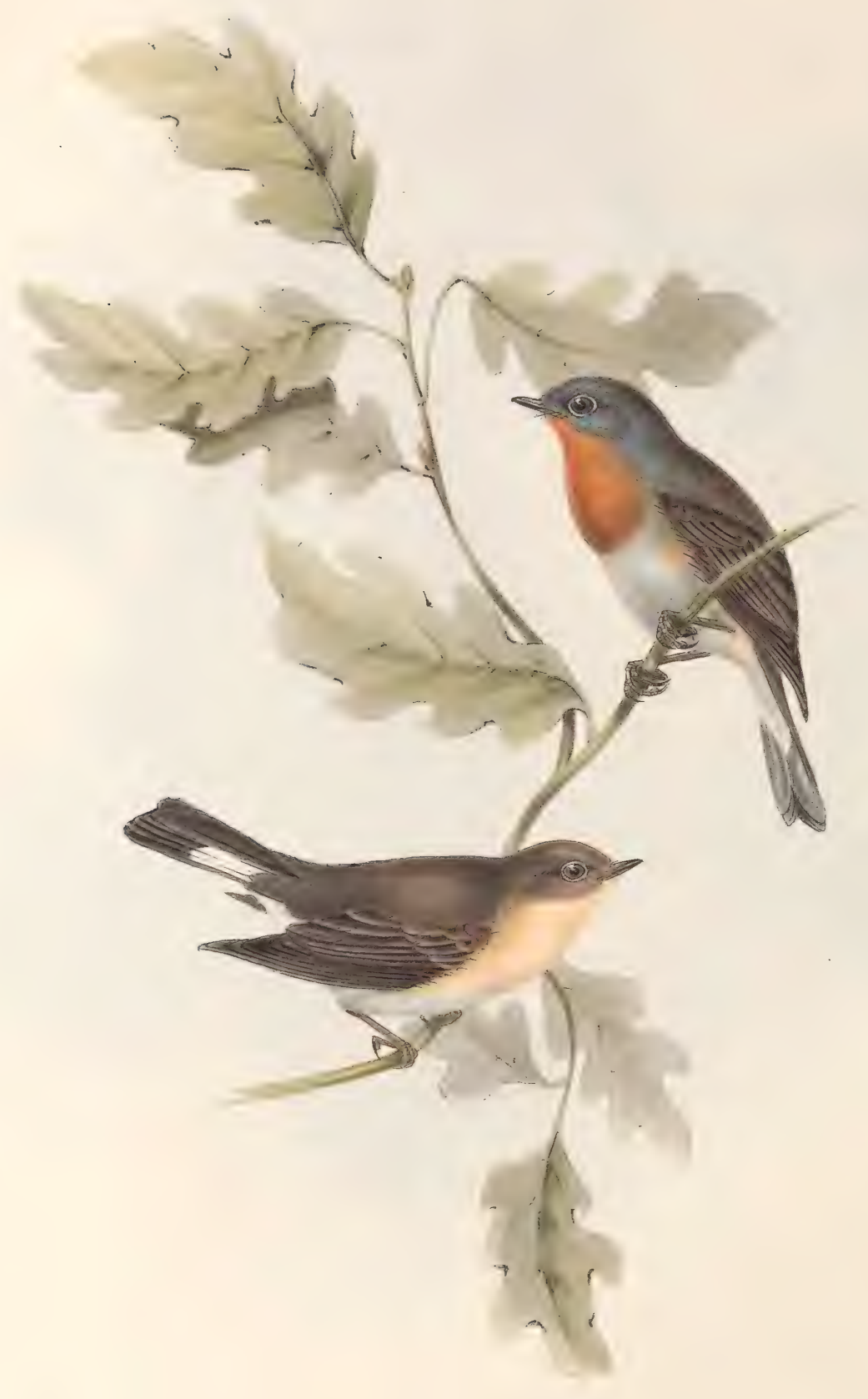

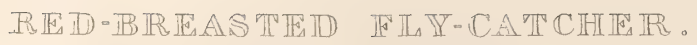

Muscicapa parva; (Bechst) 


\title{
RED-BREASTED FLYCATCHER。
}

\author{
Muscicapa parva, Bechst. \\ Le Gobe-mouche rougeatre.
}

So rare is this species of Flycatcher in the collections of Europe, and so little has been recorded of its history, that we are led to hope that the accompanying Plate illustrating the old and young bird, and the present notice of its habits and manners, will prove a trifling addition to our knowledge of European ornithology. During a recent visit to Vienna we had opportunities of observing it in a living state, both in its immature and adult plumage. Its actions and manners are strikingly peculiar, and appear to partake of those appertaining to the species of more than one genus; it resembles the Robin not only in the colour of its plumage but in several of its actions, being sprightly and animated, constantly jerking its tail and depressing its head in the manner our Redbreast is observed to do; it also imitates the action of the Whinchat in the depressed oscillating movement of the tail: thus it appears to form an intermediate link between the Muscicapide on the one hand, and the Saxicoline on the other. In the comparative length and robust form of its legs this intermediate station is also further evinced; for though the tarsi have not the strength which we see in the true Saxicolce, still they are more developed than in the genuine Flycatchers. It is a bird of migratory habits, and in Europe its habitat appears to be limited almost exclusively to the eastern portions of the continent. It is tolerably abundant in the neighbourhood of Vienna, and is known to breed annually in the woods of that district. From the circumstance of our having seen it in collections from the East Indies, particularly from that portion adjacent to Persia, it is doubtless widely diffused over the intermediate regions.

The sexes are alike in their colouring, but the female is less brilliant than the male. The upper figure in our Plate represents an adult male, and the lower one that of the young bird of the year in its second plumage, the first having been spotted like that of the Robin. M. Temminck states that the moult is simple, but that the colours of the plumage, particularly on the under surface, change periodically. Like the Muscicapide in general, the Red-breasted Flycatcher is quick and active, taking its prey on the wing with great dexterity. Its food consists of soft-winged insects, to which in all probability berries are occasionally added.

The nest, according to M. Temminck, is placed among the interwoven twigs of trees or in the forks of the branches, but of the number or colour of its eggs no information has yet reached us.

The male has the whole of the upper surface brown; the four middle tail-feathers and the extremities of the outer ones blackish brown; the base of the latter being white; the throat and breast of a bright rufous ; the under surface white tinged with rufous brown on the flanks; the beak, legs, and irides brown.

The young have the breast, which is so richly tinted in the adult, white with a slight tinge of yellow.

The figures are of the natural size. 





\title{
SPOTTED FLYCATCHER.
}

\author{
Muscicapa grisola, Linn \\ Le Grobe-mouche gris.
}

THIs species, like its congener the Pied Flycatcher, is one of the summer visitants that enliven our woods and gardens during this most pleasant season of the year. It is one of the latest of the spring birds, scarcely if ever arriving before the middle of May; but soon after this period it may be found throughout the whole of England and a portion of Scotland, wherever there exists a locality suitable to its economy : after remaining here during the summer, it migrates to more southern and congenial climates during September and October.

In its universal distribution the Spotted Flycatcher differs very considerably from the Pied Flycatcher, which is very local in its habitat; it is also less confined to large woods and plantations, and appears to give a preference to gardens, shrubberies, and orchards. It does not evince the least fear or timidity, but frequently constructs its nest and rears its young over the door of the cottager, or upon the branches of fruit-trees nailed against the walls, sometimes in the decayed holes of trees, and frequently upon the ends of the beams or rafters in the gardener's tool-house and other outbuildings.

The nest is constructed of moss and small twigs, lined with hair and feathers: the eggs are four or five in number, of a greyish white spotted with pale reddish brown. When the young quit the nest, they follow their parents to some neighbouring wood, garden, or plantation, where they are very diligently attended and fed.

The Spotted Flycatcher appears to enjoy a wide range over the continent of Europe, being very generally dispersed from the border of the Arctic Circle to its most southern boundary; and we have also frequently observed it among collections from India.

It is a most active little bird, and is incessantly engaged in capturing the smaller winged insects which pass within the range of its chosen territory. Its favourite perch is generally a decayed branch, from which it sallies forth and " returns after each of these aerial attacks."

Its note is weak and monotonous, being little more than a feeble chirp.

The sexes are precisely alike in the colour and markings of their plumage. The young for a short period after they first begin to fly have the feathers tipped with a spot of yellowish white, giving them a mottled appearance.

The whole of the upper surface is brown, the crown of the head being spotted with a darker brown; throat and belly white; sides of the neck, breast, and flanks streaked with brown; bill and legs dark brown.

We have figured an adult male of the natural size. 




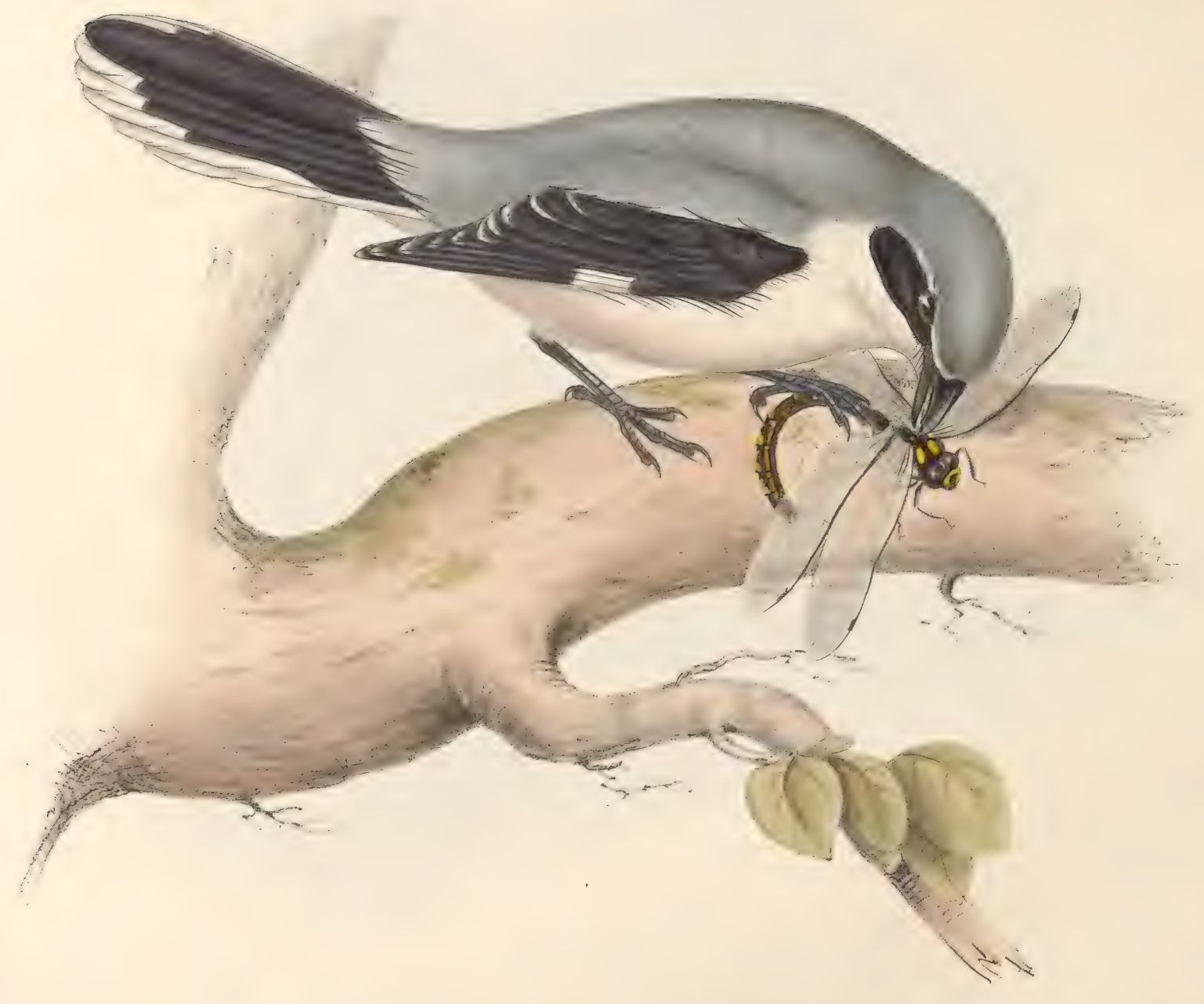

GPEAT SIIRIKE。

Lanius exeubitor. (Limn)

Collurio (lig.) 


\section{Genus COLLURIO, Vigors.}

Gen. Char. Beak and feet as in the genus Lainius. Wings somewhat rounded, short; the first quill-feather shortest; the second a little shorter than the following ones; the third, fourth and fifth, the longest and nearly equal. Tail elongated, graduated.- Type of the genus Lanius Excubitor, Linn.

\section{GREAT SHRIKE.}

Lanius Excubitor, Linn.

Collurio Excubitor, Vigors.

La Pie-grieche grise.

Tre present species forms the type of the genus Collurio as characterized by Mr. Vigors; and the reasons which induced that gentleman to separate certain birds from the genus Lanius-of which to form the genus Collurio, -were a short time ago explained by him to the Committee of Science and Correspondence of the Zoological Society, in the First Part of whose "Proceedings," page 42, the distinguishing characteristics of these two genera are clearly detailed. The principal feature which constitutes the ground of separation consists in the somewhat rounded form of wing, which in the true Lanii is more pointed,--and in the lengthened and graduated tail ; to this may be added their general superiority of size:-the Grey Shrikes in this point manifest an ascendancy over the well-known Red-backed Shrike, the more rare Wood-chat, and their allied congeners.

The Great Shrike is one of the migratory birds of Great Britain, appearing however by no means regularly, so as to lead us to expect its annual return, but must be considered an uncertain straggler, being in some seasons very scarce, and in others more abundant, and that only during the months of autumn and winter, so as to make it rather doubtful whether it ever breeds in our island, although we are aware that such is said to be the case. It is extensively spread over Continental Europe, in many parts of which it remains stationary throughout the year; but in others it performs regular periodical migrations, departing and returning with the season.

The $C$. Excubitor is a bold and courageous bird, attacking others much larger than itself, and destroying mice, frogs, and small birds for its food, of which however we believe the hard-winged insects constitute a principal portion. In killing its prey, its chief instrument is its bill, which is thick and strong, and with which it penetrates the cranium of any small animal within its power. It never strikes with its claws in the manner of the Harks, but uses them merely to assist in grasping and thus securing its victim ; for though the legs and toes are slender and apparently weak, they are well armed with claws and have the powver of tight compression. The most singular fact, however, respecting its mode of feeding or securing its prey, is its well-authenticated habit of fixing it on a thorn or sharp-pointed stick, which it selects for that purpose, and then proceeding to tear it to pieces, at the same time satisfying its appetite. Of a New Holland bird, (the Vanga Destructor, ) the same singular habit is recorded.

The specific name of Excubitor, or Sentinel, was given by Linneus as one highly appropriate, from the circumstance of this bird being used on the Continent by falconers and persons engaged in procuring falcons for the purpose of harking, especially the Peregrine during the period of its migrations. The Shrike acts as a sort of monitor, giving warning to the man in attendance of the approach of the sharp-eyed bird of prey, the appearance of which, even at a great distance, immediately elicits its querulous chattering cry. A net trap, artfully contrived, is placed for the capture of the falcon, and a live pigeon secured by a string, over which the man has perfect controul, allures the falcon to the fatal engine. In the mean time the Shrike, having warned the man of the near approach of the expected visitant, retires, as the danger increases, to a hole provided for its safety; there it continues chattering loudly, while the falcon pounces upon the fated pigeon, and is cunningly enticed by the gradual withdrawing of his victim, which he will not quit, within the circle of the net : the check-string once pulled, the capture is achieved. For its peculiar aid in this service, the Shrike is unrivalled, and when hawking was in vogue its merits were duly appreciated.

The favourite resorts of the Great Shrike are high hedges, coppices, and thick trees, among which it breeds, building a nest composed of grasses, moss, and vegetable fibres, and laying from five to seven white eggs marked with ash-grey and brownish blotches. The only difference to be observed in the plumage of the sexes, is that the breast of the female is transversely barred with faint lines of ash colour.

In the adult male the head, neck and back, are of a fine light ash; a band of black passes below the eye, and covers the ear-feathers; wings black, with a white spot in the centre, formed by the white bases of the quill-feathers; the outer tail-feathers white; the remainder black, terminating with white, which becomes more contracted as they approach the two middle feathers,-these are entirely black; beak and feet black. Length nine inches.

We have figured an adult male. 




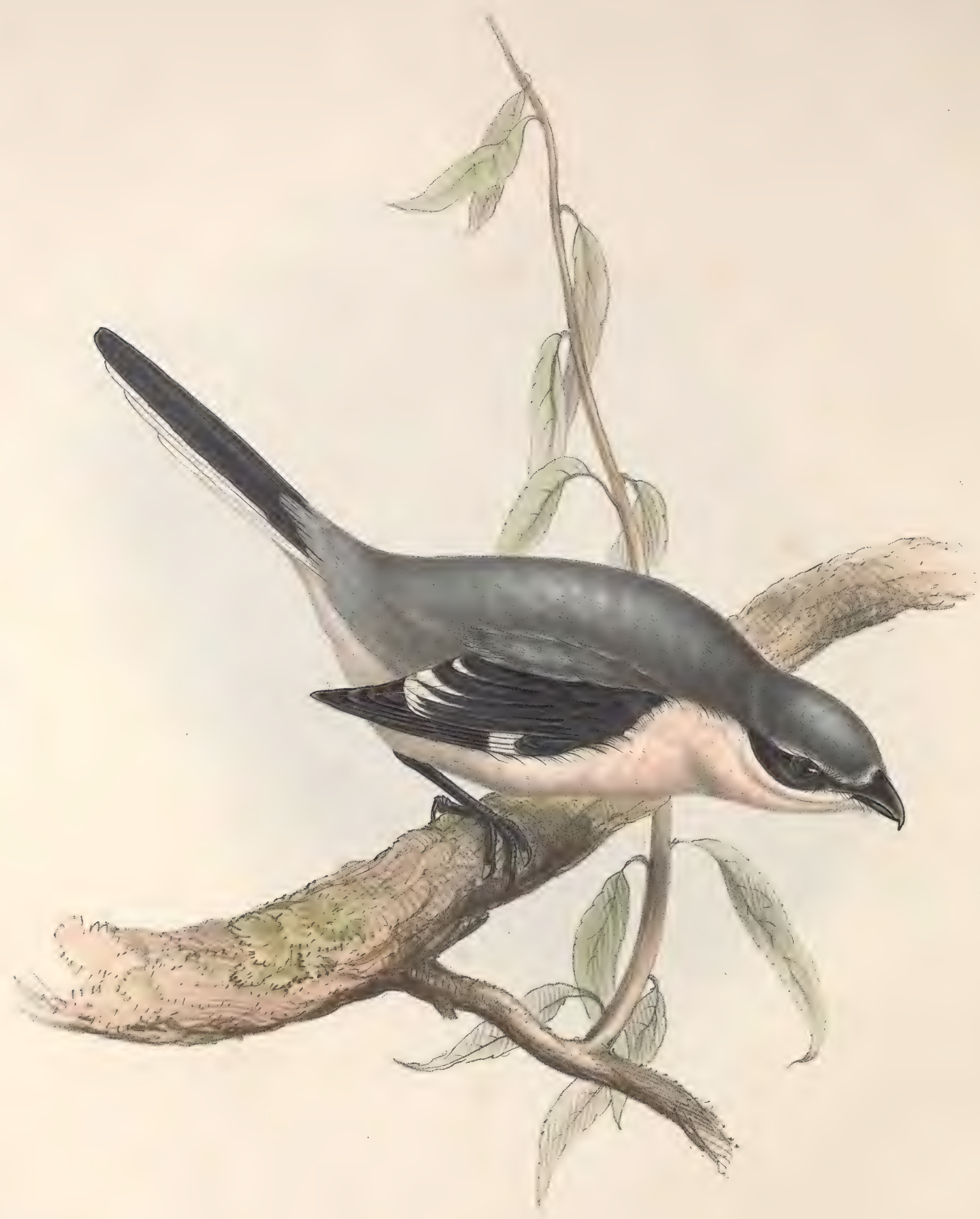

$\mathbb{G} \mathbb{R} \mathbb{A} \mathbb{A} \mathbb{T} \mathbb{R} \mathbb{E} \mathbb{S} \mathbb{E} \mathbb{R} \mathbb{I} \mathbb{E}$.

Lamius meridionatis, Temm:

Collurio_Iig. 


\section{GREAT GREY SHRIKE.}

Lanius meridionalis, Temm.

Collurio meridionalis, $V i g$.

La Pie-Grieche méridionale.

$W_{E}$ are indebted to the kindness and liberality of the officers of the British Museum, for allowing us to illustrate this fine species of Shrike from a specimen in the collection under their care, to which it was presented by Captain S. E. Cook, who obtained it in the centre of Spain; a country which, with Italy, the southern provinces of France and the districts bordering on the Mediterranean, appears to be its native habitat. Of the European Shrikes, the Lanius meridionalis is that which comes least under our notice; it is, however, the largest of its genus, and may be taken as typical of that group comprehended by Mr. Vigors under the generic title Collurio,- - a group on which we offered some remarks when speaking of that rare British species the Lanius Excubitor of Linnæus, with which the present bird closely agrees, but from which it may be distinguished by its somewhat greater size, the darker grey of the upper surface, and especially by the beautiful vinous tinge which prevades the plumage of the breast. In the latter respect, indeed, it resembles the Lanius minor; but with this bird it can never be confounded, the disparity of size being at once a distinguishing character between them, to which we may add the long and pointed wings and less graduated tail in Lanius minor, as opposed to the short wings and cuneiform tail of the Lanius meridionalis.

The habits and manners of this interesting and natural group, ally the species together as closely as their forms and colours; and although we have been able to obtain no precise information respecting our present subject, still we cannot for a moment doubt that it exhibits the same properties and acts the same tyrannical part in its mode of obtaining food as its British congener, preying upon the larger insects, especially those of the Coleopterous order, young or feeble birds, and even small mammalia. The nidification and eggs are unknown.

The top of the head and the whole of the plumage of the back are of a dark ash colour; a large black band passes below the eyes and extends over the ear-coverts; the wings are black, having the origins of the quill-feathers and the tips of the secondaries white ; the four middle tail-feathers are black, the exterior ones white; the breast and under part vinous or salmon-colour, fading into grey about the sides and thighs ; bill and legs black.

The female differs only in having the tints of the plumage more obscure, with faint transverse bars on the under parts.

We have figured a male in full plumage. 




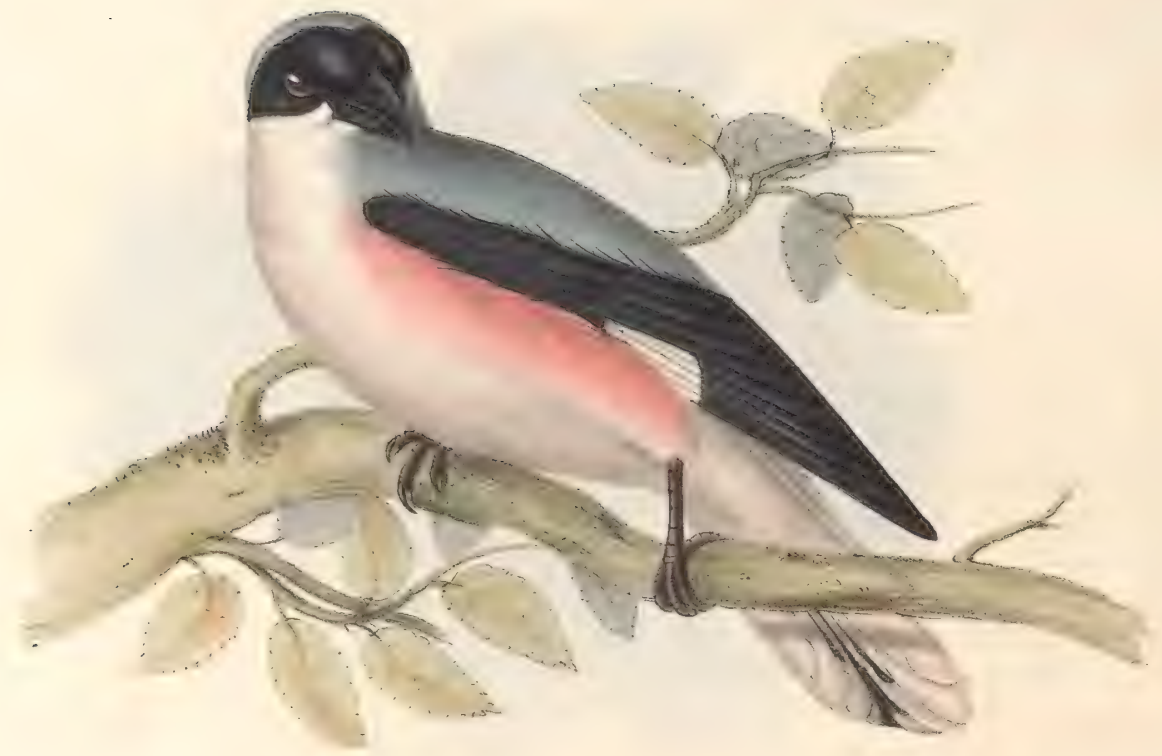

IESSER GRE SHRIIE。

Lanius minor. (Limin)

Collurio (Tid:) 


\section{LESSER GREY SHRIKE。}

Lanius minor, Linn.

Collurio minor, Vig.

La Pie-Grieche à Poitrine rose.

ThE Lesser Grey Shrike, or Rose-breasted Shrike of Temminck, though belonging to that division of the family to which Mr. Vigors has given the generic title of Collurio, (and which is distinguished from the restricted genus Lanius by the graduated tail and short rounded wing,) must nevertheless be regarded as forming a link between these two genera; inasmuch as the tail is rather rounded than decidedly graduated, and the wings are more lengthened than in any other species of the genus to which it is now assigned.

Of the European Shrikes, the present is certainly one of the most distinguished for the beauty and delicacy of its colouring: in size, it is inferior to the Lanius Excubitor of Linnæus, but possesses a more strong and robust bill than is found in that bird,--to which, however, in manners, and in the general character of its plumage, it closely approximates.

The Lanius minor is strictly Continental; no instance, so far as we are aware, being on record of its ever having visited our Island. From M. Temminck, to whose acquaintance with the birds of Europe the scientific world is so much indebted, we learn that its range on the Continent is very extensive, inhabiting, with the exception of Holland (in which it is rarely seen), Turkey, the Archipelago, Italy and Spain, breeding also in some parts of France and Germany, and visiting the northern portions of Europe as far as Russia. Thickets, trees, bushes, and hedge-rows are its favourite resort, among which it constructs its nest: the eggs, six in number, are oblong and of a dull green, having a zone of small spots round the centre, of an olive-grey.

Its food, like that of the other species of the genus, consists principally of insects, such as moths, and coleoptera, to which young or feeble birds are occasionally added.

The beak and legs are black; a black band passes over the forehead, eyes and ears; the top of the head, back and rump of a fine ash ; throat white ; breast and sides of a delicate rose-colour; wings black, with a white bar across the quill-feathers; the middle tail-feathers black, the two outer feathers quite white, the two next partially white, the succeeding feathers on each side less and less so.

The female differs as little from the male as those of the allied species Excubitor, and is only to be distinguished by the more obscure rose-colour of the breast, and the black of the plumage having a tinge of brown.

The young of the year of both sexes after the autumn moult are destitute of the black band on the forehead, which remains grey during the winter, and the plumage of the superior surface is more or less broken with grey, the under parts being obscure; but after the moult of spring, both sexes gain the band over the forehead and ears, the rose-colour of the breast becoming at the same time more lively. Total length eight inches.

Our figure represents an adult male of the natural size. 




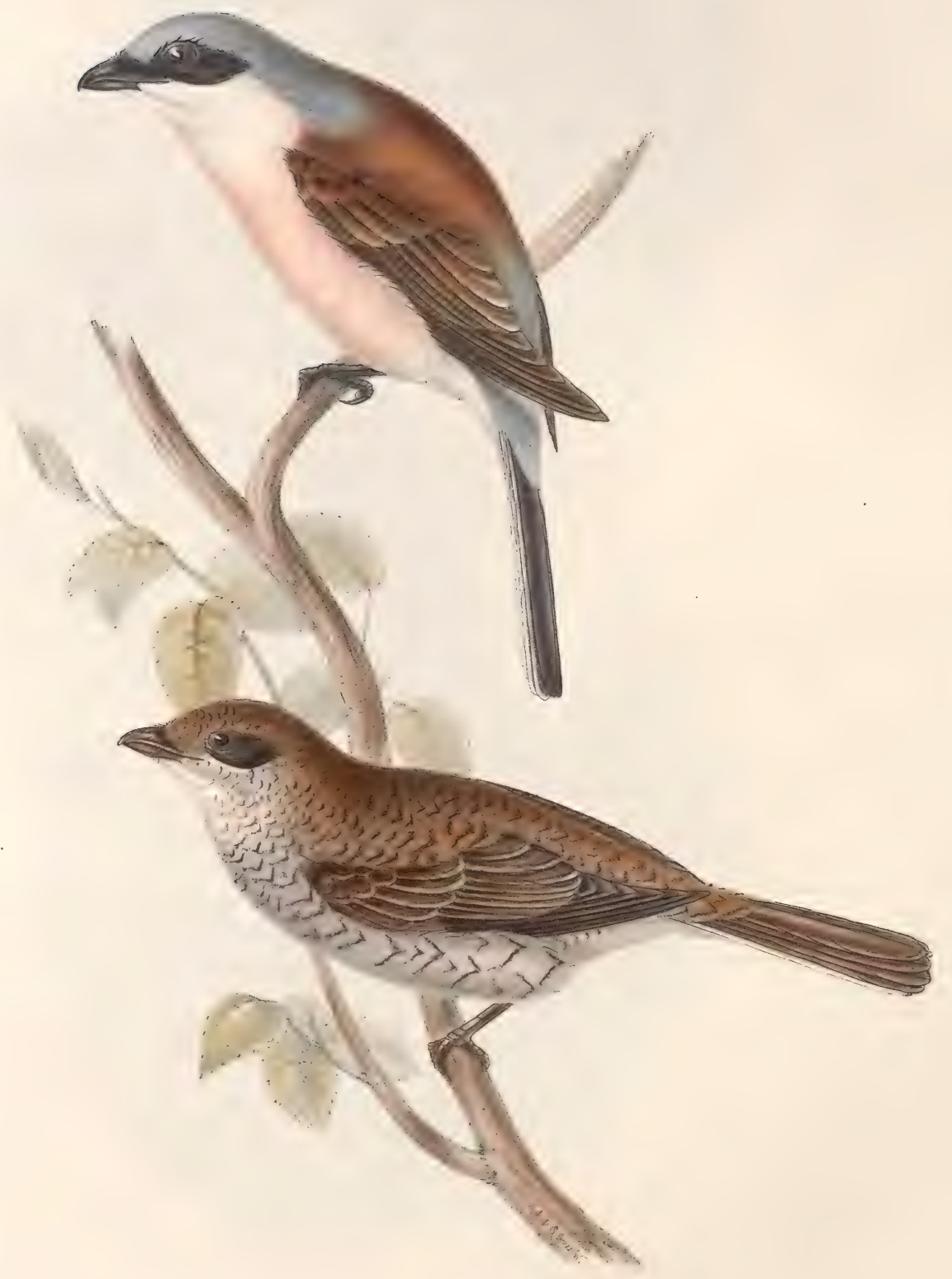

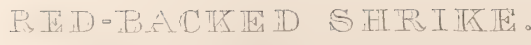

Lanius collurio; (Linn:) 


\title{
Genus LANIUS.
}

Gen. Char. Beak of moderate length, robust, compressed, straight at the base, curved at the tip; edges of the upper mandible emarginated, and exhibiting a conspicuous tooth. Nostrils basal, lateral, nearly round, partly covered by a membrane. Gape furnished with stiff bristles. Feet moderate. Toes free. Acro-tarsia broadly scutellate. Wings somewhat pointed and rather short; the first quill-feather very short; the third the longest; the rest gradually decreasing. Tail equal, or somewhat rounded.

\section{RED-BA CKED SHRIKE.}

\author{
Lanius Collurio, Linn.
}

Le Pie-griéche écorcheur.

Aмомq the Shrikes which periodically visit our island, the Red-backed is the best known and most universally spread. Its arrival usually occurs from the middle of April to the beginning of May, the exact period being regulated by the forwardness of the spring, inasmuch as its food consists almost solely of insects, the appearance of which depends upon the temperature of the season. Though found occasionally in the northern counties of England, it is by no means so abundant there as in the middle, and more especially the southern districts. In Scotland it is, we believe, altogether unknown, nor are we aware of its having been discovered in Ireland. It is partial to downs and open pastures, particularly such as are intersected or bordered by thick stunted hedges, where it may be commonly met with singly or in pairs, but never in flocks. Like the rest of the Shrikes, its manners and note are very peculiar, and serve at once to distinguish it from the small birds of other groups. Its chief food, as we have before observed, consists of insects, such as grasshoppers, beetles, and the larger kinds of flies, which it often takes on the wing. It may be generally noticed quietly perched in some commanding situation awaiting the approach of its prey, upon which it darts not unlike a Flycatcher, generally returning to the same perch. Besides insects, it is known to attack young and feeble birds, mice, lizards, slugs, \&c., which, as is the case with most of its congeners, it impales on a sharp thorn or spike previously to tearing them to pieces.

Though small in size, the Red-backed Shrike is extremely fierce and courageous, defending itself with great obstinacy when wounded or assailed. On the Continent it is widely distributed, being spread throughout every province of Europe, from the south as far as Russia and Sweden; and we may add that it is also a native of the North of Africa.

The Red-backed Shrike builds its nest in sharp thorny bushes, often at a considerable distance from the ground, constructing it of dried grasses and wool, with a lining of hair. The eggs are five or six in number, of a pinkish white, with spots of wood-brown disposed in zones chiefly at the larger end.

The sexes offer very considerable difference in their colouring; that of the adult male is as follows :

Top of the head, occiput, upper part of the back, and rump, fine grey; a narrow band of black begins above the beak, passes round the eye, and spreads over the ear-coverts; middle of the back and shoulders fine chestnut; quills brown; two middle tail-feathers black; the rest white for more than half their basal length, the extremity being black tipped with white; throat white; under surface pale roseate; bill and tarsi black.

The female wants the beautiful grey hood and mantle, as also the black streak on the face; the whole of the upper plumage is dull reddish brown, with dusky transverse lines more or less obscure; a deeper tint of brown pervades the quills and tail-feathers; the under surface is white, barred on the sides of the neck, the chest, and flanks, with fine semilunar lines of brown.

The young males of the year closely resemble the adult female ; in fact, the only difference consists in the feathers of the back being, in the former, more distinctly margined with transverse lines of brown.

Our Plate represents an adult male, and a young male of the year, of the natural size. 




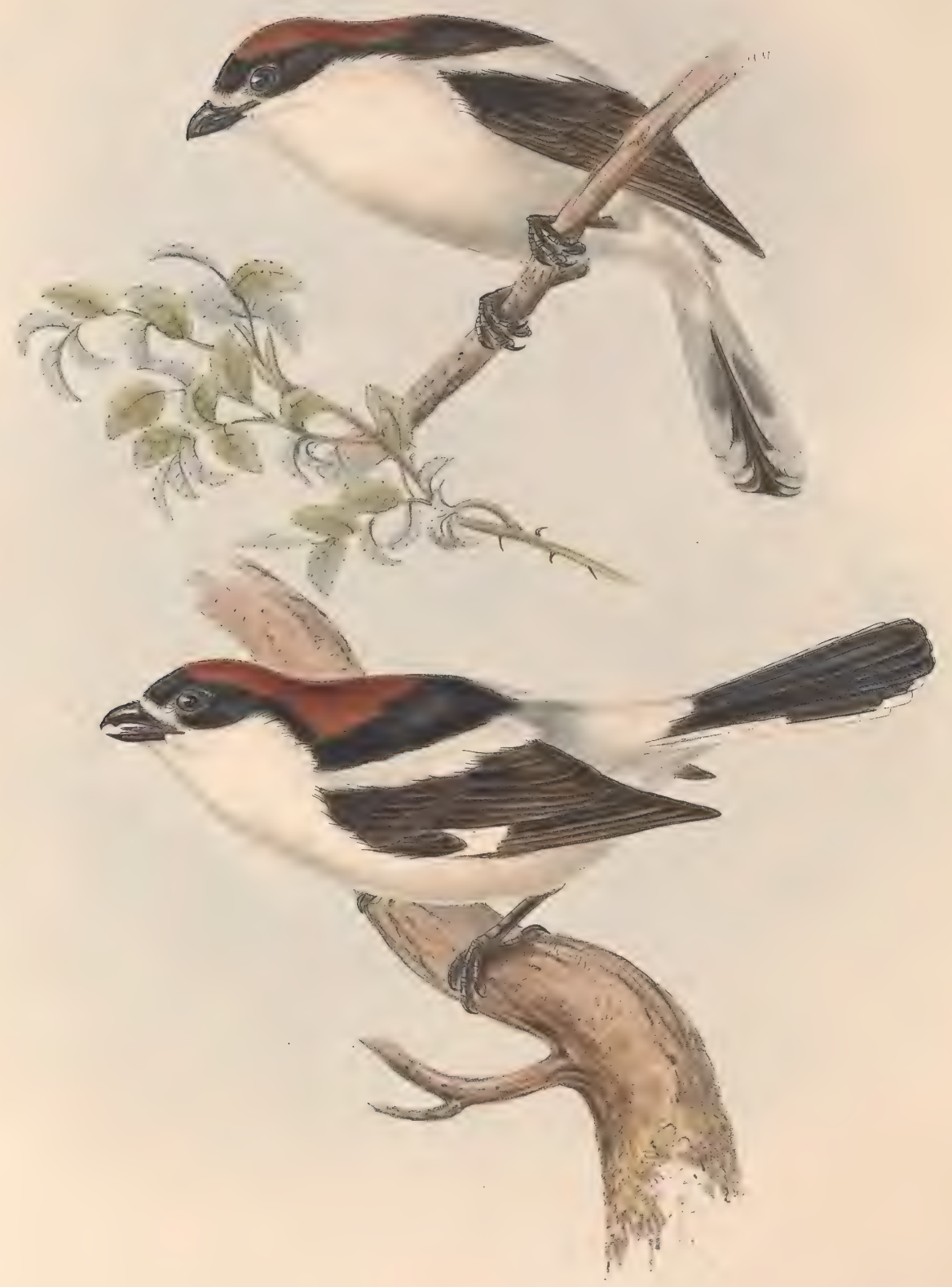

WVOD D $\mathbb{C} \mathbb{A} A \mathrm{~T}$.

Lamius rufus: (Brifs.) 


\title{
W O O D CHA T.
}

\author{
Lanius rufus, Briss.
}

La Pie-grièche rousse.

\begin{abstract}
Axтноugn the Woodchat is abundantly spread over the Continent, particularly the warmer portions, such as Spain, Italy, and all the countries bordering on the Mediterranean, it is so rare in the British Islands as scarcely to merit a place in our Fauna; indeed, two or three instances of its having been seen or captured in England are all that we are acquainted with, and we bave ourselves never received it in a recent state. In general habits and manners it strictly resembles its nearly allied species the Red-backed Shrike, Lanius Collurio ; but a moment's comparison will be sufficient to establish the distinctions of the two species. In one respect, however, the Woodchat appears to be peculiar; we allude to the circumstance of the nearly allied style of colouring of the two sexes, which is contrary to what prevails in the Red-backed Shrike, and agrees more strictly with the rest of the European representatives of the present family. The only point by which the sexes may be distinguished is the less brilliant colouring of the female.

The food of the Woodchat consists of coleopterous and other large insects, and occasionally small and nestling birds. According to M. Temminck, it builds its nest in bushes, selecting the fork of a small branch among foliage sufficiently dense for its concealment. It lays five or six eggs, of a whitish green, irregularly blotched with grey.

The plumage is as follows: A narrow white band borders the margin of the upper mandible, and is followed by a black belt across the forehead; the same colour occupying the ear-coverts passes down the sides of the neck and the middle of the back, where it fades off into grey; the occiput, back of the neck, and upper part of the back, rich chestnut; wings black, the scapularies and a bar across the base of the quills being white ; upper tail-coverts white, with a tinge of yellow; tail black, except the outer feather on each side, which is nearly white, and the next, which is tipped with white, and is white at its base; the third is also tipped with white; beak and tarsi black.

In the female the black is tinged with brown, and the chestnut of the back is less vivid.

The Plate represents a male and female of the size of life.
\end{abstract}






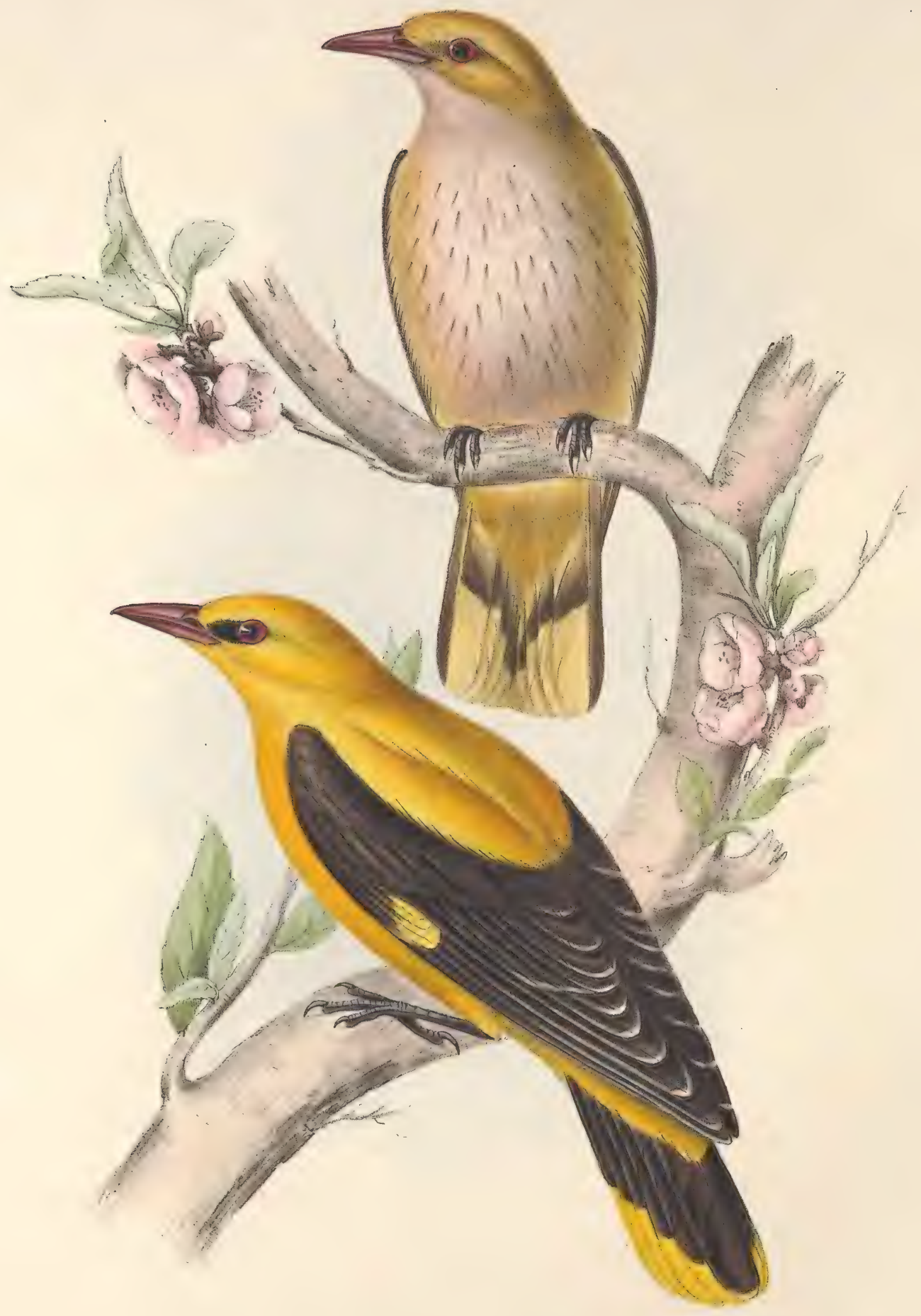

$\mathbb{G} \mathbb{O} \mathbb{I}_{A} \mathbb{D} \mathbb{E}_{A} \mathbb{N} \quad \mathbb{O} \mathbb{R} \mathbb{I} \mathbb{O} \mathbb{I}_{s} \mathbb{E}_{s}^{\prime}$ 。

Oriolus Galbula, (Lizn). 


\section{Genus ORIOLUS.}

Gen. Char. Beak conical, straight, and sharp-pointed, flattened at its base; upper mandible ridged and slightly notched at the point. Nostrils basal, lateral, naked, and pierced horizontally in a large membrane. Feet three toes before and one behind, the external toe united to the middle one at its base. Tarsus not exceeding the middle toe in length; third quill-feather the longest.

\section{GOLDEN ORIOLE.}

Oriolus galbula, Linn.

Le Loriot.

THE genus Oriohus, as restricted by modern authors, comprises a group of birds pre-eminent for their beauty and the contrast of their colours, rich yellow and deep black dividing the plumage in proportions varying according to the difference of species; and there is no genus the members of which are more naturally united to each other than the present.

The Orioles are strictly confined to the older or longest known portions of the globe; various species being respectively disposed over Asia, Africa, the islands of the Indian Archipelago, and the southern and eastern portions of Europe. Their place in America appears to be supplied by the Icteri and the other genera of the family of Sturnida.

The Golden Oriole is to be considered as merely an occasional sojourner in England, its visits being but few, and only during the months of summer. Although undoubtedly scarce, it is by no means the most rare of those birds which, from their occurrence in England, have been admitted to a place in its Fauna. We are not aware that there are any instances on record of its breeding in this country : still we have reason to suppose that such would be the case, if, when it favours any part of our island with its residence, it were permitted to remain unmolested. In Italy and the whole of the southern provinces of Europe it is very abundant, and is also far from being uncommon in France, Holland, Germany, and some of the districts of Russia ; paying all those countries an annual visit, for the purpose of incubation. We have received numerous specimens of this bird from Tripoli and the whole line of the northern coast of Africa, where it is exceedingly common; and to which country, or at least its more northern parts, we have reason to suppose it migrates when absent during the winter months from Europe. We have never received this identical species from India, although there is one, the $O$. aureus, which closely approximates to it, but which may at once be distinguished by its rather smaller size, and by the black line passing through and beyond the eye, while in the European species the black colour reaches only to the anterior edge of the orbit. We have been informed that this latter species has also been found in Europe, which is not unlikely, as the border line of the two continents is merely conventional.

The nest of the Golden Oriole, like that of many of the natives of the tropical climates, is a striking example of ingenuity : it is composed of fibres of hemp or other vegetables ingeniously interwoven together, lined with fine moss or lichen, and suspended at the extremity of the tallest branches of lofty trees; the eggs are four or five in number, the ground-colour being a pure white, marked by a few well-defined purple brown, or black spots. Its food consists of wild berries and fruits, as well as insects and their larvæ.

In the male, the beak is brownish red; irides red; general plumage fine king's yellow, a black streak intervening between the beak and eye; the wings black with a bar of yellow; all the quill-feathers tipped with yellowish white; the two middle tail-feathers black; the rest have their basal half black, and the other portion yellow ; tarsi lead-colour; claws black. Length of the bird ten inches.

In the female, the yellow of the upper parts is clouded with an olive tinge, and below with grayish white, each feather having a longitudinal mark of a darker colour; the wings are brownish black, and the tail-feathers, where black in the male, are obscure olive.

The young of the year resemble the female, but have the longitudinal markings of the lower parts stronger; the irides brown, and beak of a dark gray.

Our Plate represents a male and female of the natural size. 




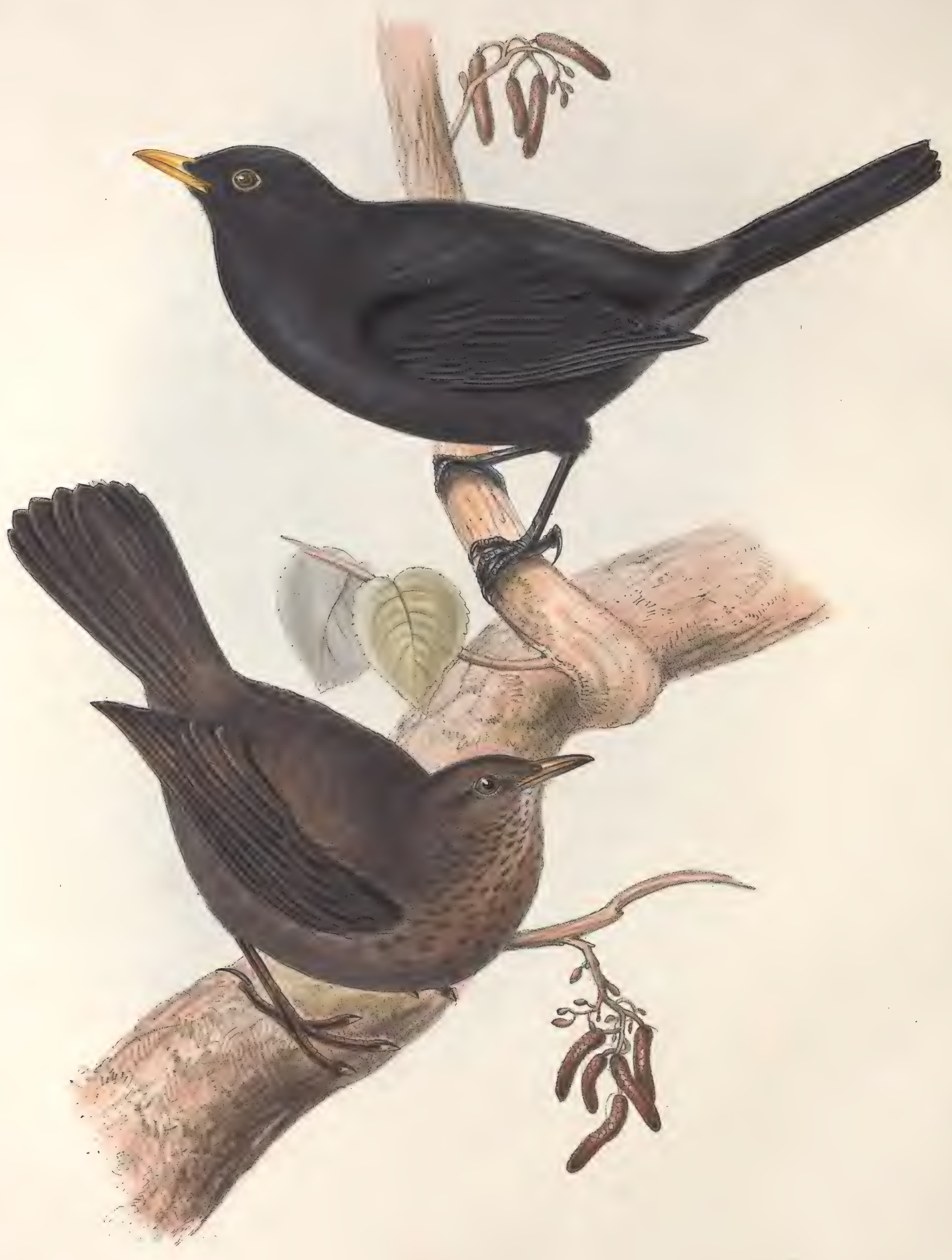

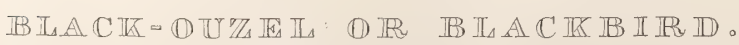
Merula vulgaris; (Ray). 


\title{
Genus MERULA.
}

Gen. Char. Bill nearly as long as the head; straight at the base; slightly bending towards the point, which is rather compressed; the upper mandible emarginated; gape furnished with a few bristles. Nostrils basal, lateral and oval, partly covered by a naked membrane. Legs of mean length, muscular. Toes, three before and one behind; the outer toe joined at its base to the middle one, which is shorter than the tarsus. Clares slightly arcuate; that of the hind toe the largest. Of the wings, the first quill is short, and the third and fourth are the longest.

\section{BLA C K OUZEL， O R BLA CK B IRD.}

\author{
Merula vulgaris, Ray.
}

Le merle noir.

THIS familiar species is very generally distributed over Europe ; and although it is stationary with us throughout the year, yet in some parts of the Continent it is a bird of passage; and we may add, that on the approach of severe winters the number in our own island is greatly augmented by temporary visiters from the North.

When we consider the style of colouring, form, and habits of this bird, with those of the Ring Ouzel and some other European species, we cannot but agree with our countryman Ray in considering them fully entitled to rank as a genus distinct and separate from that of Turdus, with which Linnæus and his followers blended them.

In their habits these birds are more terrestrial than the true Thrushes, frequenting secluded copses, hedgerows and ravines, as well as gardens and shrubberies, skulking about under the bushes, and retiring from observation with great celerity. Towards evening they may often be seen extremely restless and clamorous, uttering a shrill chatter as they dart from bush to bush in chase of each other before retiring to rest. It is more solitary in its habits than the Thrush, there seldom being more than two or three in the same immediate locality. There is also a slight degree of difference in the general construction of the nest, the colour of the eggs, and the situations chosen for the purpose of nidification, to which we may add the marked difference in colouring between the male and the female.

The song of the Blackbird, though not so melodious as that of the Thrush, is a clear bold strain, which, when heard in the calm mornings and evenings of spring, is very delightful, and renders the bird a general favourite. In its food the Blackbird is perfectly omnivorous, accommodating itself to such as the season offers : in winter it lives on berries, worms, and shelled snails, which it seeks for under hedgerows and other hiding-places; in summer, on worms, insects and their larvæ, as well as all kinds of fruits that the garden and hedgerow afford.

The Blackbird appears to be strictly confined to Europe, but its form is represented in the Himalaya mountains by an interesting and nearly allied species the Turdus poccilopterus, and in the tropical regions of America by two or three other species.

It is an early breeder, often commencing the work of nidification in the months of February and March, building its nest in thick secluded bushes, laurels, ivy, or any densely leaved covert : the nest is constructed externally of moss, small trvigs, and fibres plastered with mud, internally of fine dry grass : the eggs are usually five in number, of a blueish green blotched with reddish brown.

The young of both sexes greatly resemble the female, but are generally more spotted.

The male, with the exception of the bill and the orbits of the eyes, which are of a beautiful orange, is entirely of a jet black.

The female is of a deep umber brown inclining to black; the chest, belly and thighs, varied with dashes of a darker colour.

The Plate represents a male and female of the natural size. 




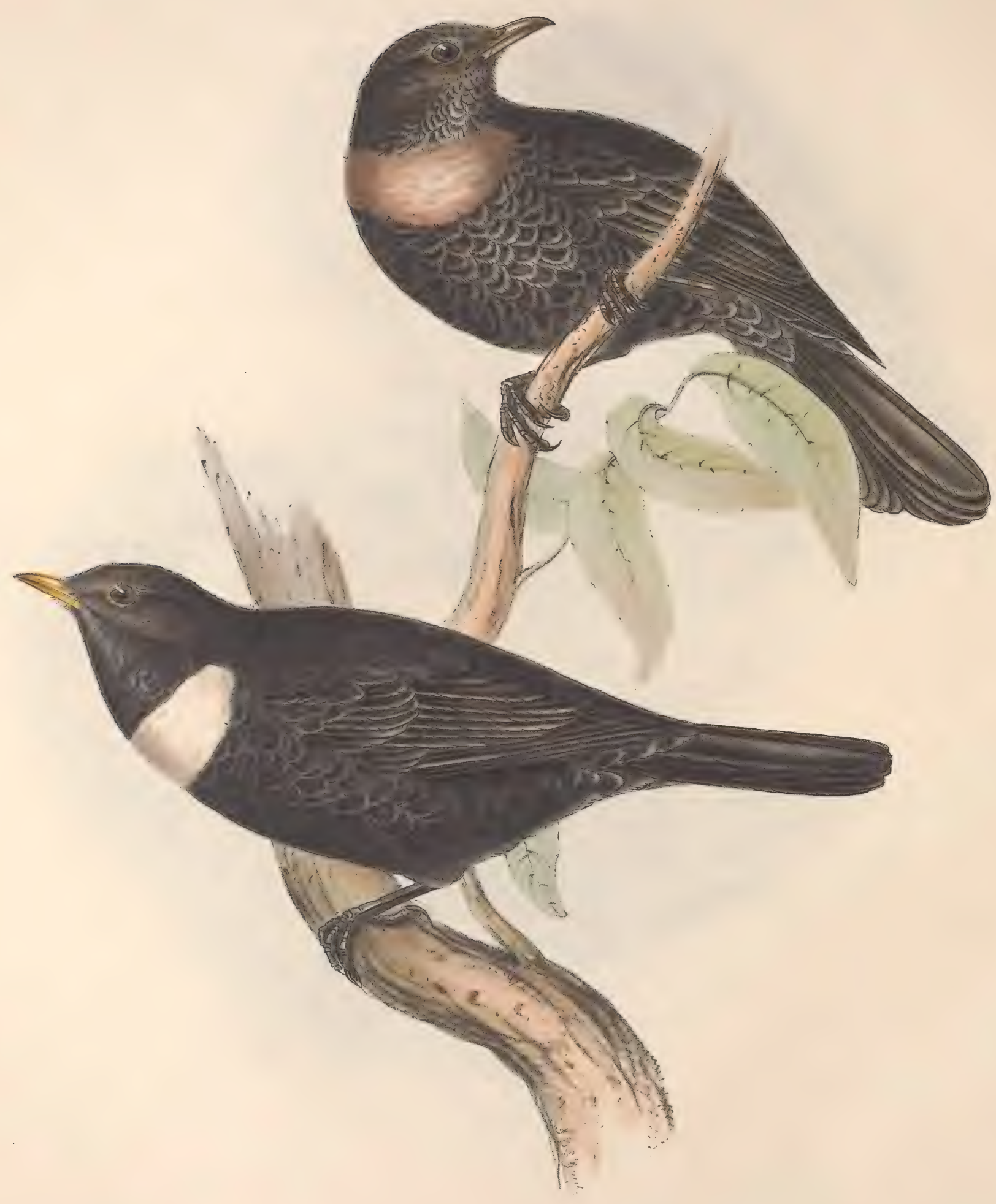

$\mathbb{R} I \mathbb{N} \mathbb{G} \quad \mathbb{O} \mathbb{U} \mathbb{U} \mathbb{Z}_{\Delta} \mathbb{F}_{\Delta} \mathbb{I}_{s}$

Merula torquata; (Brifs). 


\section{R I N G O UZEL.}

Merula torquata, Briss.

Le Merle à Plastron blanc.

"THE periodical visits of this bird to our coast," says Mr. Selby, "are contrary to the others of the genus that migrate, viz. the Fieldfare, the Redwing, and the Common Thrush, as it arrives in spring, and immediately resorts to the mountainous districts of England and Scotland, preferring those that are the most stony and barren." Although it doubtless always breeds in the situations above described, it may not unfrequently be seen traversing the hedgerows of cultivated lands during its passage to and from distant climates.

In general form and appearance it strictly resembles the Blackbird, but in its manners it is much more shy and distrustful, rarely admitting itself to be approached. Unlike that bird, it is not observed skulking among bushes, \&c., but affects more open situations, which doubtless renders it habitually cautious, as being more necessary to its safety. Its voice is somewhat harsh and powerful, consisting of a few notes, which, according to Mr. Selby, are not unlike those of the Missel Thrush. On the Continent it is distributed through most of the northern countries, and is very common in Sweden, France, and Germany ; indeed, with the exception of Holland, it is universally distributed throughout Europe, as well as the adjacent parts of Asia and Africa. In all these countries it is said to be migratory; and we may easily conceive the cause of this to be the failure of a supply of food in the peculiar situations it frequents, and the consequent necessity of retiring to a more genial climate, where berries, fruits, and insects may be easily obtained.

The male differs from the female in the greater purity and contrast of his colours. The general plumage is black, each feather having a margin of grey; a broad gorget of pure white extends across the chest; the bill is blackish brown at the tip, and yellow at the base; legs blackish.

The plumage of the female is more clouded with brownish grey, the pectoral gorget being less extensive and tinged with dusky brown.

The young males closely resemble the adult female, but in young females the gorget is scarcely perceptible.

The Plate represents an adult bird of each sex of the natural size. 




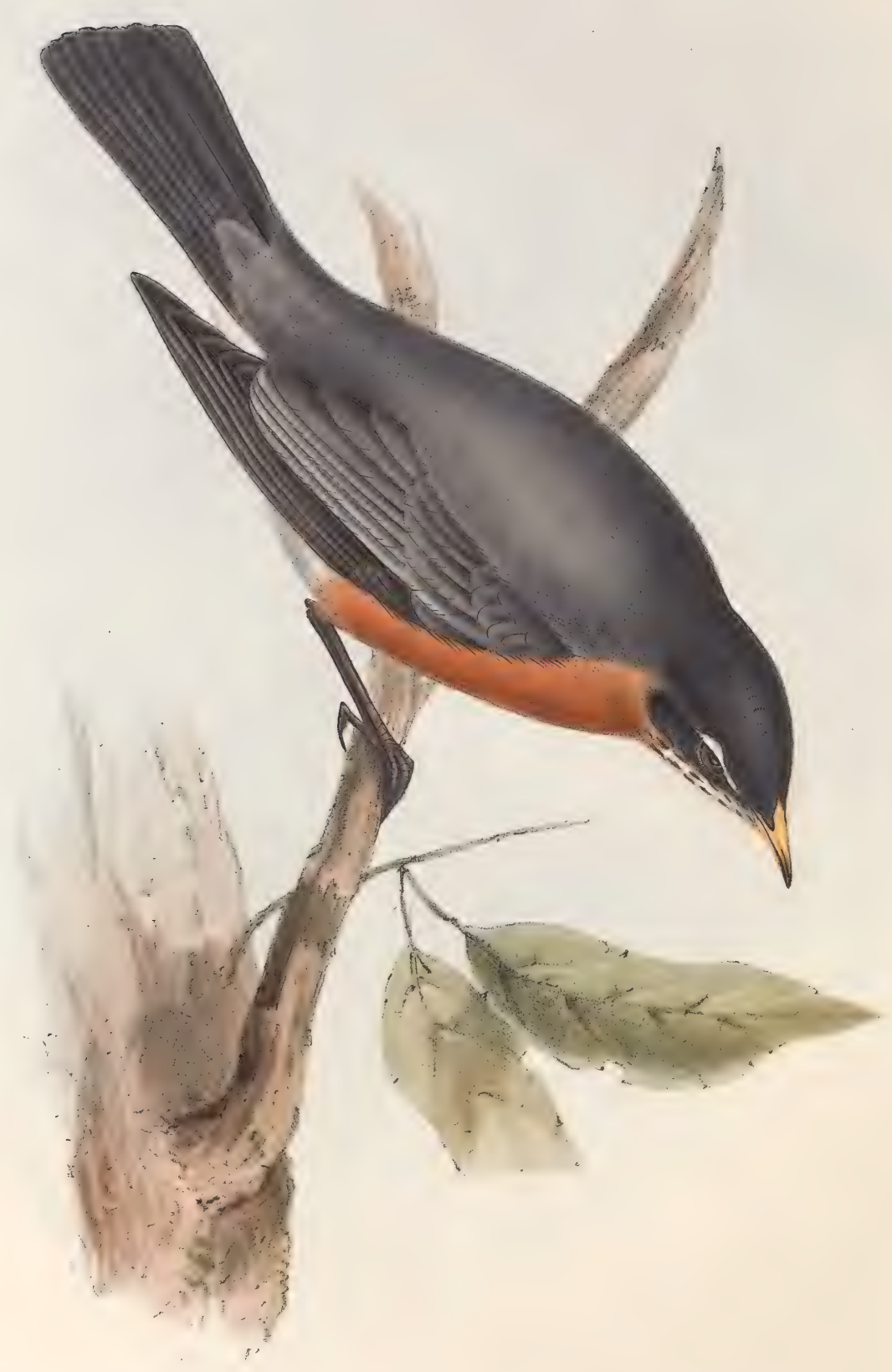

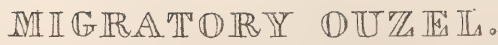

Merula migratoria; /Swains:) 


\title{
MIGRATORY OUZEL。
}

\author{
Merula migratoria, Sroains.
}

Le Merle erratique.

THrs beautiful species of Thrush, if not the theme of poets, has nevertheless called forth many spirited and flowing descriptions, the most animated of which are to be found in the works of Wilson, Audubon, and Dr. Richardson. From the latter author we find that few of the feathered race seek a more northern region for the purpose of breeding than the Migratory Ouzel. "It arrives in the Missouri (in lat. $41 \frac{1}{2}^{\circ}$ ), from the eastward, on the 11th of April ; and in the course of its northerly movement, reaches Severn River, in Hudson's Bay, about a fortnight later. Its first appearance at Carlton House, in lat. $53^{\circ}$, in the year 1827 , was on the 22nd of April. In the same season it reached Fort Chepewyan, in lat. $58 \frac{3}{4}^{\circ}$, on the 7 th of May, and Fort Franklin, in lat $65^{\circ}$, on the 20 th of that month. Those that build their nests in the fifty-fourth parallel of latitude, begin to hatch in the end of May; but eleven degrees further to the north, that event is deferred till the 11th of June. The snow even then partially covers the ground; but there is, in those high latitudes, abundance of the herries of the Vaccinium uliginosum and Vitis idcea, Arbutus alpina, Empetrum nigrum, and of some other plants, which after having been frozen up all the winter, are exposed, on the first melting of the snow, full of juice and in high flavour. Shortly afterwards, when the callow young require food, the parents obtain abundance of grubs."

When we take into consideration the migratory habits of this bird, and the extreme high northern latitudes it affects, the fact of its occasionally occurring in Europe is not so startling as it would otherwise appear : a single glance at a globe will in fact make it plain to our readers, that when migrating from these high latitudes, a slight deviation from its regular course would carry it on to the continent of Europe, where, as we have before stated, it is occasionally seen. In the third part of his 'Manuel' M. Temminck states that it has been killed in Germany; and M. Brehm informs us that it has been seen in the neighbourhood of Vienna. In its affinities we are inclined to consider this bird as a true Merula, or as belonging to that section of the Merulide which includes the Common Blackbird, and we also find that its habits, manners, song, and nidification are much in raccordance with those of that bird. "So much," says M. Audubon, " do certain notes of the Robin (the American name for the Merula migratoria) resemble those of the European Blackbird, that frequently while in England the cry of the latter, as it flew hurriedly off from a hedge-row, reminded me of that of the former when similarly surprised, and while in America the Robin of that country has in the same manner recalled to my recollection the Blackbird of England."

The sexes are alike in plumage, but the tints of the female are somewhat paler, and she is also smaller in size.

Head and sides of the face deep sooty black; round the eye a circle of white; all the upper surface fuliginous grey tinged with brown on the shoulders; wings and tail blackish brown externally edged with grey ; two outer tail-feathers tipped with white; chin white spotted with brownish black; breast and under surface reddish orange, each feather delicately fringed with grey; vent and under tail-coverts mingled white and grey; bill yellow; irides hazel; feet pale brown.

We have figured an adult of the natural size. 




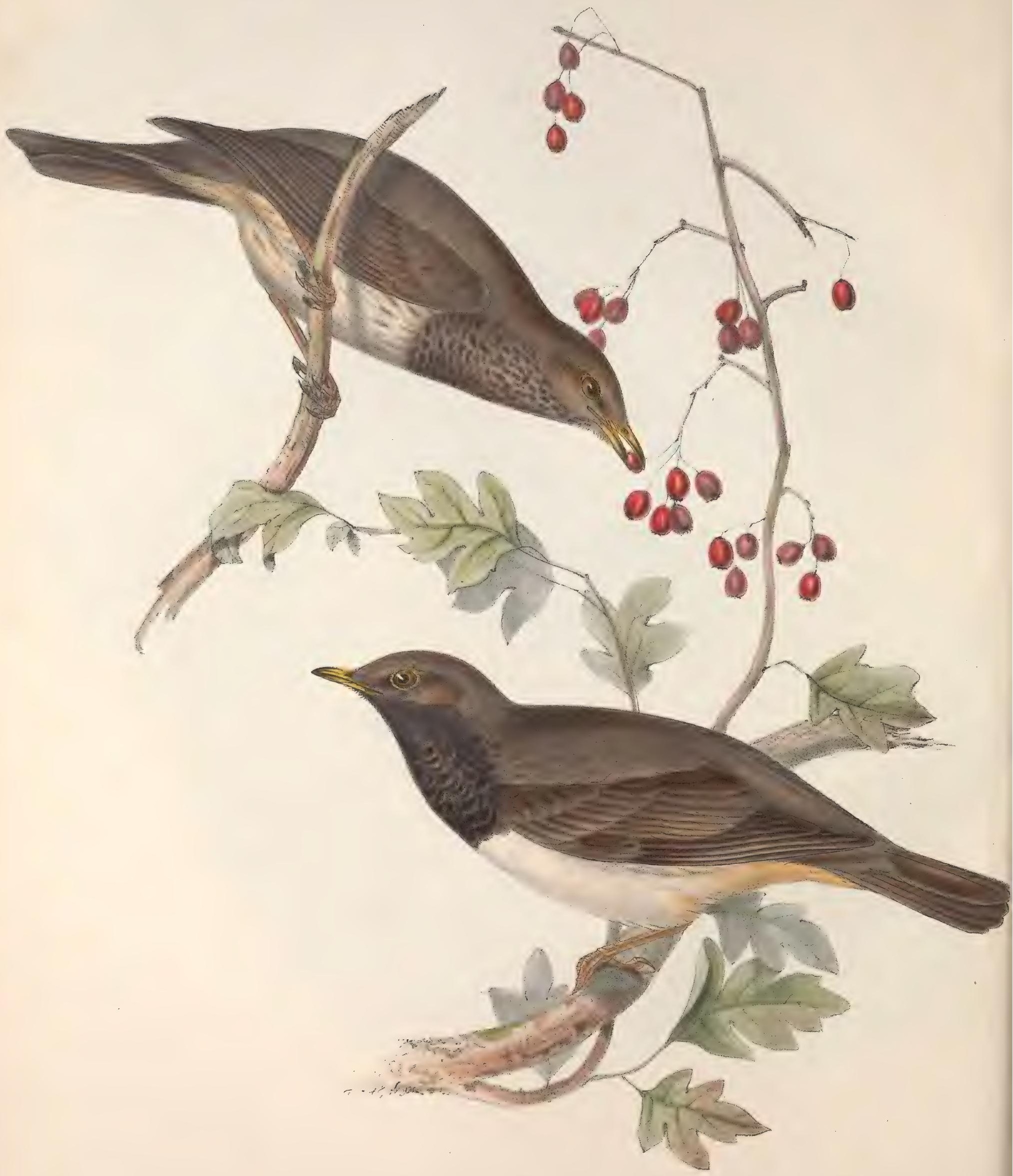

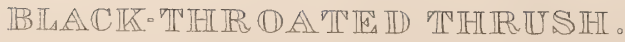

Turdus atrogularis: (Temm) 


\section{BLACK-THROATED THRUSH.}

Turdus atrogularis, Temm.

La Merle à gorge nöire.

THIs fine bird is one of the ornithological rarities of the Fauna of Europe : it is, however, a species of common occurrence in the Himalaya mountains, whence we have received numerous examples, differing in no respect from those taken in Europe. Although M. Temminck states that it is a native of Hungary and Russia but rare in Austria and Silesia, we have only seen two native-killed specimens, which are in the collection at Vienna, and one of them was, we believe, killed in the neighbourhood of that city : young birds are also said to have been taken in Germany. From the circumstance of most collections from the Himalaya mountains containing examples of this bird, the fact is clearly established that the northern and higher regions of Asia constitute its native habitat. Our knowledge of this species is so limited that we are unable to state with certainty whether the black gorget is characteristic of the summer plumage, or whether when once acquired it is permanent: we suspect the latter to be the case, as we have received specimens in various stages of plumage, some of which were totally devoid of the black throat, while others had it partially developed; in all probability these last were females or immature birds.

The whole of the upper surface is brown with a slight tinge of red, the outer edges of the wing-feathers being somewhat lighter; throat and chest dull black, each feather being slightly margined with white; belly white; under tail-coverts rufous brown; bill dark at the point and yellow at the base; feet brown.

The Plate represents a male and a young male or the female of the natural size. 




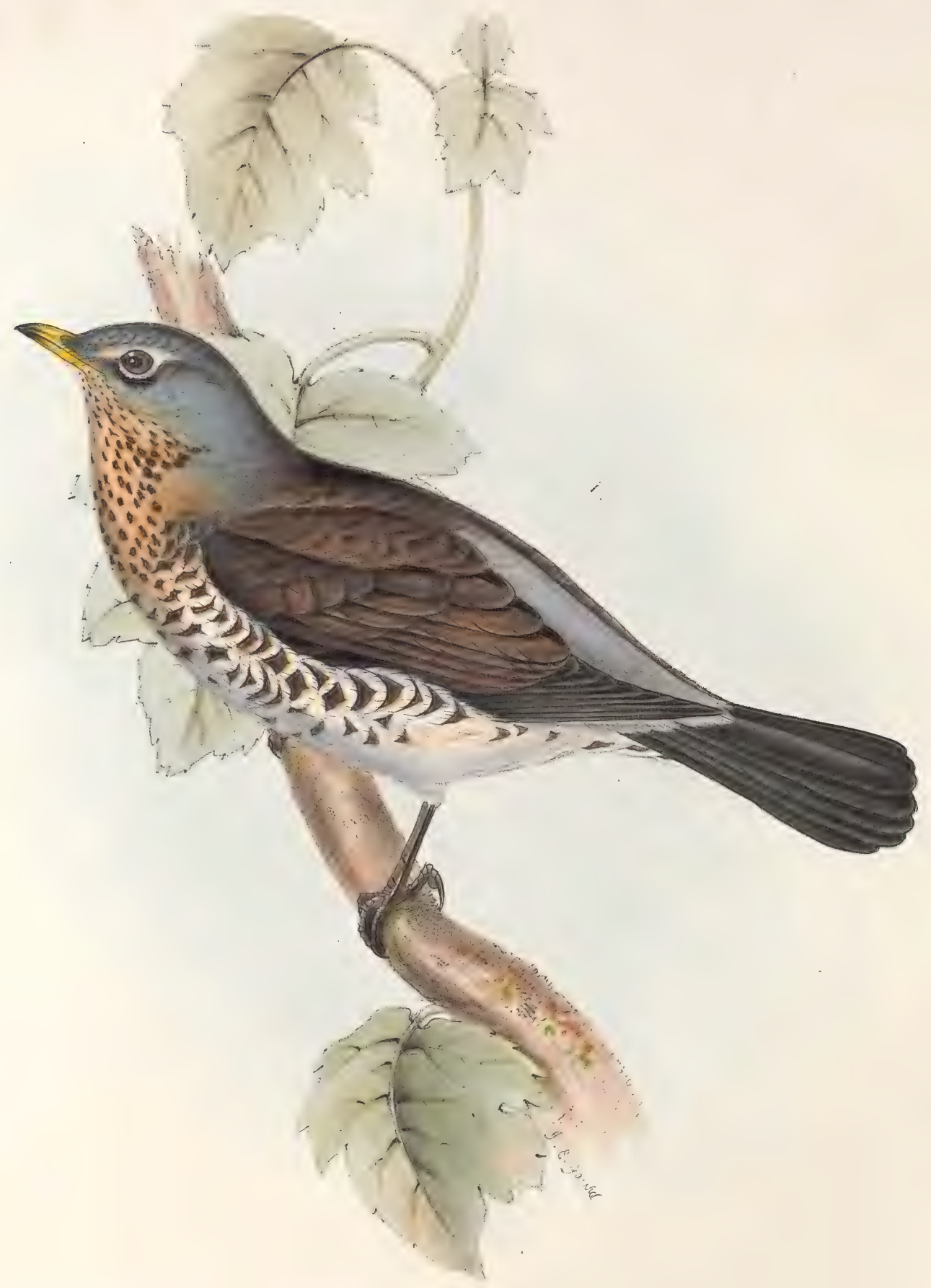

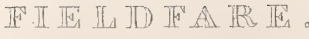

Turdus pilaris; (binn) 


\section{FIELDF A R E.}

Turdus pilaris, Linn.

Le Merle litorne.

ThE Fieldfare is only a winter visitant of the British Islands and the temperate parts of Europe, arriving in autumn and departing northwards in the spring, its native habitat being the regions adjacent to the arctic circle, such as Sweden, Lapland, the Northern parts of Russia, Norway, \&c., where, according to Mr. Hewitson of Newcastle, it is very abundant. From this gentleman's interesting and very valuable work on the eggs of British Birds, we have made the following extract: "We were soon delighted by the discovery of several of their nests, and were surprised to find them, so contrary to the habits of other species of the genus with which we are acquainted, breeding in society. Their nests were at various heights from the ground, from four feet to thirty or forty feet or upwards, mixed with old nests of the preceding year. They were, for the most part, placed against the trunk of the spruce fir ; some were, however, at a considerable distance from it, upon the upper surface and towards the smaller end of the thicker branches. They resemble most nearly those of the Ring Ouzel : the outside is composed of sticks, and coarse grass and weeds gathered wet, matted together with a small quantity of clay, and lined with a thick bed of fine dry grass. The eggs are five and sometimes six in number, very like those of the Blackbird and Ring. Ouzel. The Fieldfare is the most abundant bird in Norway, building as above described in society, two hundred nests or more being frequently found within a very small space."

After the breeding season is past, and when the severities of winter set in over those northern regions, vast flocks congregate together and pass gradually southwards till they find a locality affording the necessary means of subsistence; hence, in our locality they spread themselves over fields and pasture lands in search of worms, grubs, and insects, retreating to thick hedges, where various berries supply them food, when the snow precludes their other means of support. Unlike the Song Thrush they are shy and wary, not allowing themselves to be approached, but taking wing and wheeling off in a body to some distant spot. This shyness of disposition, together with the harshness of their note, assimilates them strongly to the Missel Thrush, which in fact they closely resemble, except in their gregarions habits.

The sexual differences in the Fieldfare are so trifling as to be scarcely perceptible; indeed, it requires anatomical examination to ascertain the distinction.

The Fieldfare generally leaves us in March or April, and, as far as we know, there are no instances of their having bred in our island. Their powers of song are very moderate, and their common call note very like that of the Shrikes.

Their flesh is by many held in considerable esteem, and hence they are often eagerly pursued by the gunner, a circumstance which, if we mistake not, conduces much to their timid and suspicious habits.

In size, the Fieldfare is next to the Missel Thrush, but possesses a style of colouring peculiar to itself. The head, lower part of the neck and rump cinereous grey; the top of the back and wing-coverts chestnut brown; space between the beak and the eye black; a greyish white streak passes above the eyes; the throat and breast light rufous brown, with lanceolate black spots; the feathers of the flanks are blotched with black and bordered with white; the abdomen pure white; tail black, the outer feathers being inclined to grey; bill bright orange, with a black tip; tarsi black.

The Plate represents an adult bird of the natural size. 




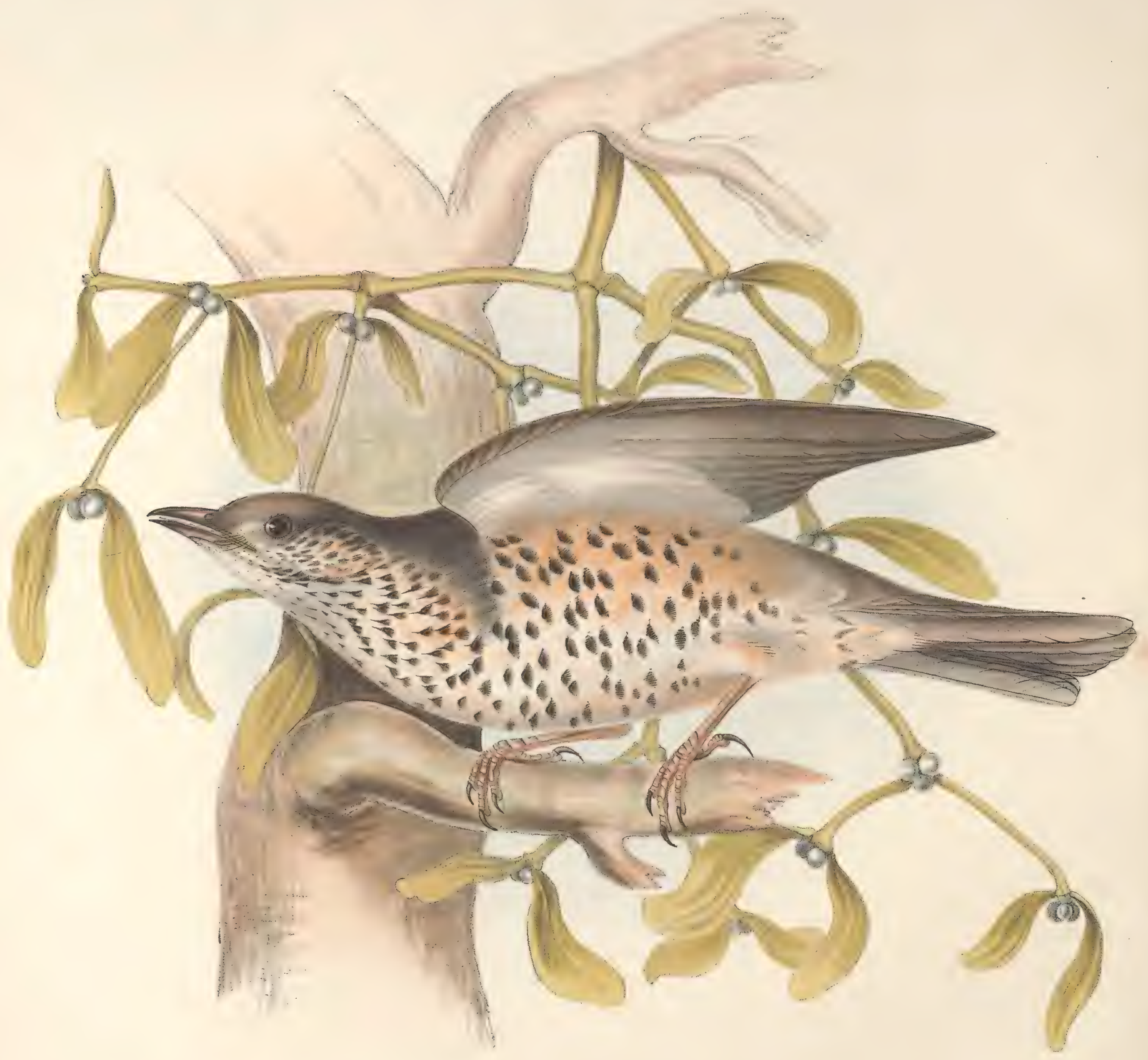

MYISSEIS THRUSH.

Turdus viscivorus. (Linn) 


\section{Genus TURDUS. Auct.}

GeN. Char. Beak moderate, emarginated, compressed and arched at its point. Upper mandible slightly notched. Gape furnished with a few bristles. Nostrils basal, lateral, oval, partly closed by a naked membrane. External toe joined at its base to the middle one, which is shorter than the tarsus. First quill-feather very short; third or fourth the longest.

\section{MISSEL THR USH.}

Turdus viscivorus, Livn.

\section{La Draine.}

THrs bird has derived its appellation from the alleged circumstance of its feeding upon the berries of the Misseltoe; and we place it at the head of the genus as being the largest, and exhibiting the generic characters in the greatest perfection. Of all the Thrushes, the present species is the most extensively spread over the older continent, being not only found in Europe, but also in that altitude of the Himalaya Mountains and the high lands of Asia which afford a temperature similar to our own. Thinly dispersed over the British Isles, the Missel Thrush is a solitary and unsocial bird, differing considerably in its habits from the common favourite, which delights to dwell within the cultivated precincts of our shrubberies and gardens. Affecting remote situations, it retires from the haunts of human society to pasture lands, wide commons or meadows skirted by orchards or groves, feeding, like its generic companions, on snails, worms and the larvæ of insects, during the months of spring and summer, but resorts to berries, especially those of the mountain ash, the haw, and, according to authors, the misseltoe, when autumn and winter deprive it of more esteemed fare. It is one of our earliest breeders, the commencement of March being the season of incubation; the place of nidification being sometimes orchard trees, at others those of more lofty growth, such as the elm or oak; and the nest, with a view to its concealment, is artfully placed either close against the stem or in a fork of one of the larger branches, being composed on the outside of coarse lichen, gray moss, or such dried vegetables as are found on the spot and accord with the colour of the tree: the materials are carelessly interwoven. Within this outside covering is a layer of mud neatly lined with fine grasses ; the female laying five eggs of a pale blueish white spotted with dull red.

As this bird is one of our earliest breeders, so also may the note of the male be heard the earliest in the spring, while, perched at the top of some tall tree, he serenades his mate with loud discordant sounds, which consist of monotonous unpleasant notes, repeated by the hour together. The Missel Thrush is very pugnacious during the breeding season, attacking all birds indiscriminately should they intrude within a certain distance of his nest. After this period we have seen the Missel Thrush collected in small companies, but never in such congregated numbers as the migratory species of the genus.

The male and female differ from each other so little in size and colour, that one description will serve for both : the young, however, have their feathers edged with a darker colour, which soon disappears, when the plumage assumes the adult colouring.

The weight of the Missel Thrush is near five ounces; its total length eleven inches.

The whole of the upper surface is of an ashy brown; between the beak and eye the feathers are gravish white. The under-surface is white, more or less tinged with yellowish red varied with barb-shaped brown spots, which become more oval on the lower parts; wing-coverts edged and tipped with white; the three outer tail-feathers ending in a lighter colour; beak and legs yellowish white, the former the darkest.

The annexed Plate represents an adult male in its spring plumage. 



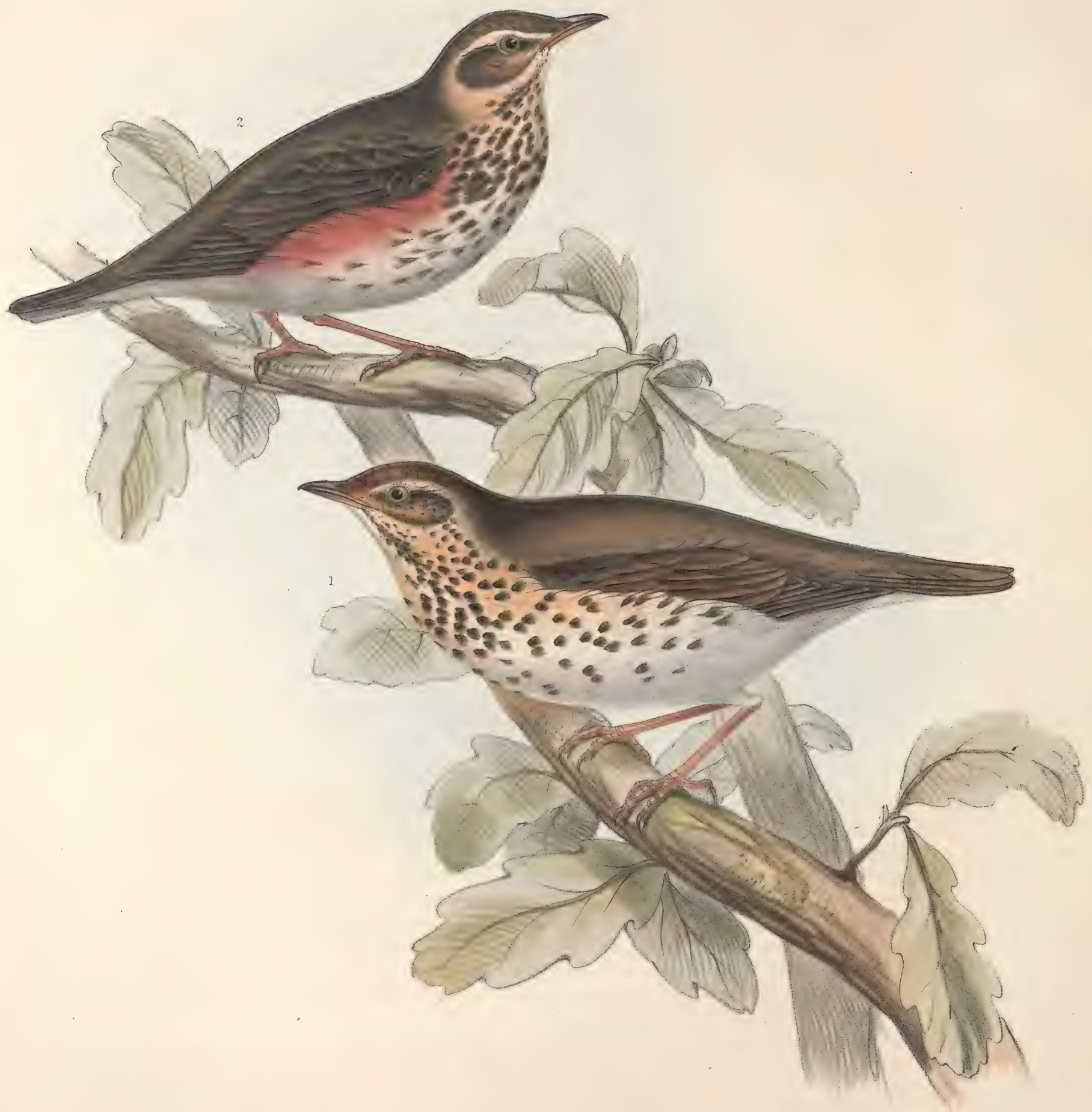

S D ING TITHIRUS IFT 。

1. Turdus musicus; / Limn.
$\mathbb{R} \mathbb{E} \mathbb{D} \mathbb{W} \mathbb{N} \mathbb{G}$ 。

2. Turdus Iliacus: (Linn:) 


\section{SONG THRUSH.}

Turdus musicus, Linn.

La Merle grive.

THIs universal favourite appears to inhabit every country in Europe, which may be considered its true habitat. It may be taken as a typical example of the true Thrushes, which, as a tribe, are numerously dispersed over a great portion of the globe: the temperate countries of America afford us several examples of this particular form ; both Asia and Africa as well as the Indian Islands having also their melodious Thrush. It is very generally dispersed over the wooded districts of the British Islands, and is particularly partial to shrubberies and thick hedge-rows. It is by no means fearful or suspicious of man, confidently venturing within the precincts of gardens and orchards, where its bold, varied and energetic song secures it good-will and protection. It builds its nest early in the spring a few feet from the ground, in any tree or shrub within the immediate vicinity of its haunt. Its nest is outwardly constructed of coarse moss intermingled with dead leaves and grasses; the inside is neatly covered with a composition of cow-dung, light vegetable mould, and clay; and without any other lining the female deposits her eggs, which are usually four or five in number, of a beautiful blue colour spotted with black.

The habits of the Song Thrush differ materially from those of the Redwing and Fieldfare. It is not gregarious; and although numbers annually arrive here from more northern countries, they scatter themselves singly over the fields and thickets in search of that food which the season affords. As the severities of winter approach, numbers appear to continue their migrations still further south; but it rarely occurs that our island is left entirely destitute.

The young at an early age assume the markings and general appearance of the parent birds : the difference in plumage which the sexes present is so trifling as to be scarcely distinguishable.

Their food consists of worms, insects, snails (more especially the Helix nemoralis), and fruits.

The head and upper parts are of a brownish olive; sides of the neck and breast of a pale yellow, the latter varied with arrow-shaped spots of rich brown; centre of the belly white; under wing-coverts pale reddislorange, but neither so deep or decided in colour as in the Redwing; base of the bill and legs light brown; tip of the bill inclining to black.

Our Plate represents an adult bird in mature plumage.

\section{RED WIN G.}

Turdus Iliacus, Linn.

La Merle mauvis.

THIs bird is strictly a migratory species ; for although it frequently remains with us for the greater part of the year, viz. from October till May or June, it invariably retires to the pine forests of Norway and Lapland for the purpose of breeding. It is rather inferior in size to the Thrush, and unlike that bird is gregarious, visiting us in the autumn in flocks of considerable numbers, and when the weather is mild frequenting pasture lands, feeding on insects, worms, \&c. On the approach of frost, it subsists on the berries of the white thorn, mountain-ash, and ivy, the last of which it is very partial to, particularly in the spring. We have seen this plant in the month of May, entirely stript of its fruit by the Redwing. We have often known this bird perish from starvation when the winter has set in early and severe, in which case they subsist as long as there are any berries remaining on the trees before named; but when this resource fails, they have not strength to proceed further south, and inevitably perish.

The habits of the Redwing are much more shy and suspicious than those of the Thrush. It evinces a great partiality for tall trees and woods, and never lives in low hedges and bushes like the Thrush. Its song is similar to that of the Thrush, with the exception of being less porverful; it often sings sweetly before it leaves us for its more congenial and favourite breediug places.

Head and whole of the upper surface olive brown; the space between the bill and the eye dark brown, intermingled with yellow; a streak of yellowish white extends over the eye; sides of the neck and flanks white with obscure blotches of brown; belly pure white ; under wing-coverts reddish orange; legs light brown; the sexes present no external differences.

We have figured an adult male of its natural size. 




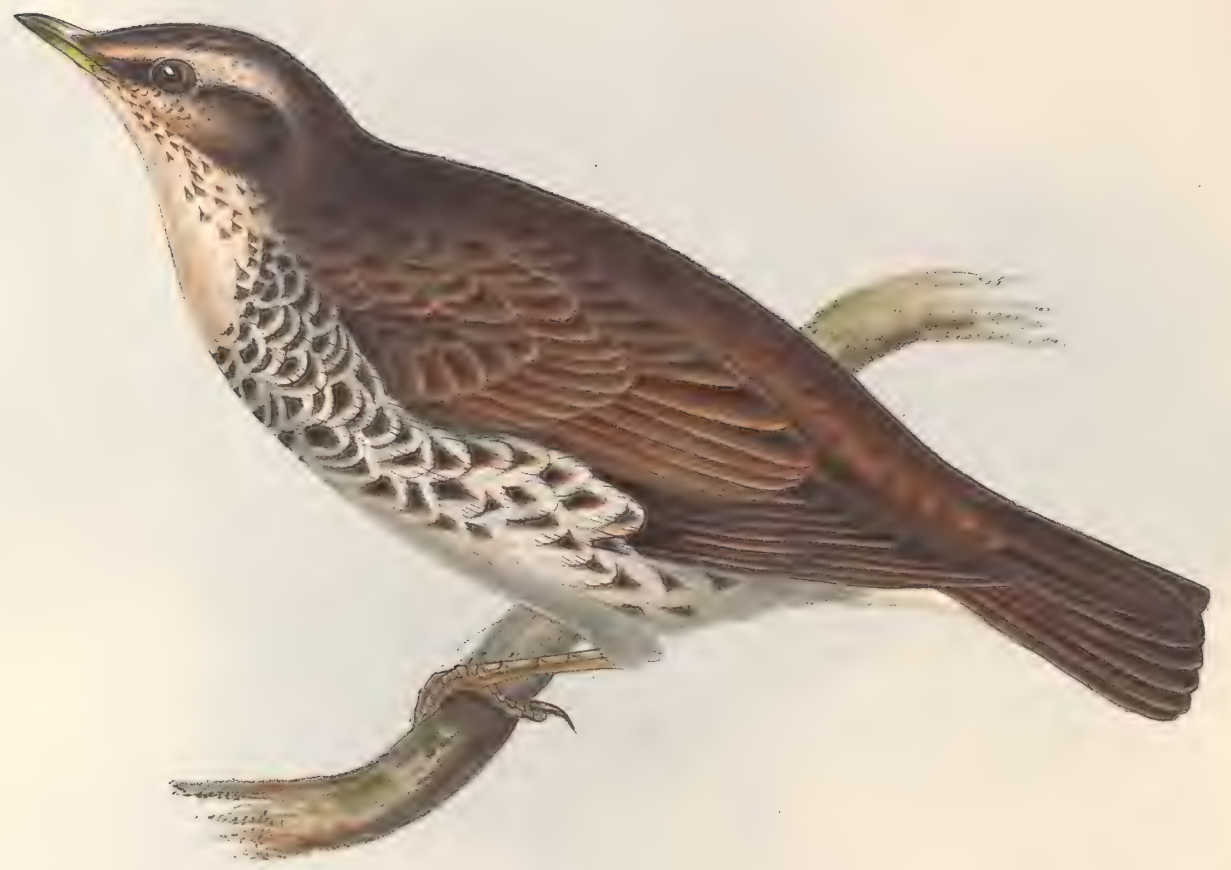

$\mathbb{N} \mathbb{A} U \mathbb{M} \mathbb{A} \mathbb{N}^{\circ} S \quad T^{P} \mathbb{H} \mathbb{R} \mathbb{U} \mathbb{S} \mathbb{H}$.

Turdus Naumannii; (Termm:) 


\title{
NA UMA N N'S THRUSH.
}

\author{
Turdus Naumannii, Temm.
}

Le Merle Naumann.

So directly intermediate is this bird between the Fieldfare and Redwing, that had we not seen numerous examples we should have been inclined to consider it either an accidental variety or a hybrid produced between these two well-known birds. Although it does not occur in Europe so frequently as is mentioned by M. Temminck, still we have seen it in Continental collections; one in particular we recollect to have observed in the Museum at Munich, which was killed near that city: it appeared to be fully adult, and was in beautiful preservation. From the little information we could obtain respecting it, we can state with certainty that it is a species of the greatest rarity, visiting only the eastern portions of the Continent alone, and at very indefinite periods. It is strange that we have never observed a single specimen among the vast collections which have been sent home from India during the last few years, although that country directly intervenes between the eastern portions of Europe and Japan, where it is abundant. Two fine examples collected in the latter country have been transmitted to us by our valued friend M. Temminck; these specimens offer little or no difference from the bird in the Munich Museum, of which our Plate is an accurate representation.

Of its habits and nidification nothing is known; but in its general economy, food, \&c., it doubtless resembles the other members of the group.

The sexes are scarcely distinguishable by their plumage; the female, like those of the Fieldfare and Redwing, being only somewhat smaller in size, and rather less bright and decided in her markings.

Top of the head, ear-coverts, and upper surface deep brown, each feather being edged with reddish, which red tint becomes more conspicuous on the rump, scapularies, and secondaries; a stripe of pale buff passes from the base of the bill over the eye; throat and upper part of the breast very pale buff; the sides of the neck ornamented with fine arrow-shaped markings of brown; chest and flanks dark brown, each feather broadly bordered with greyish white; belly white; under tail-coverts buff; tail and primaries dark brown, the outer edges of the tail-feathers tinged with reddish; feet light brown ; bill light brown at the base, passing into dark brown at the tip.

The Plate represents a male of the natural size. 




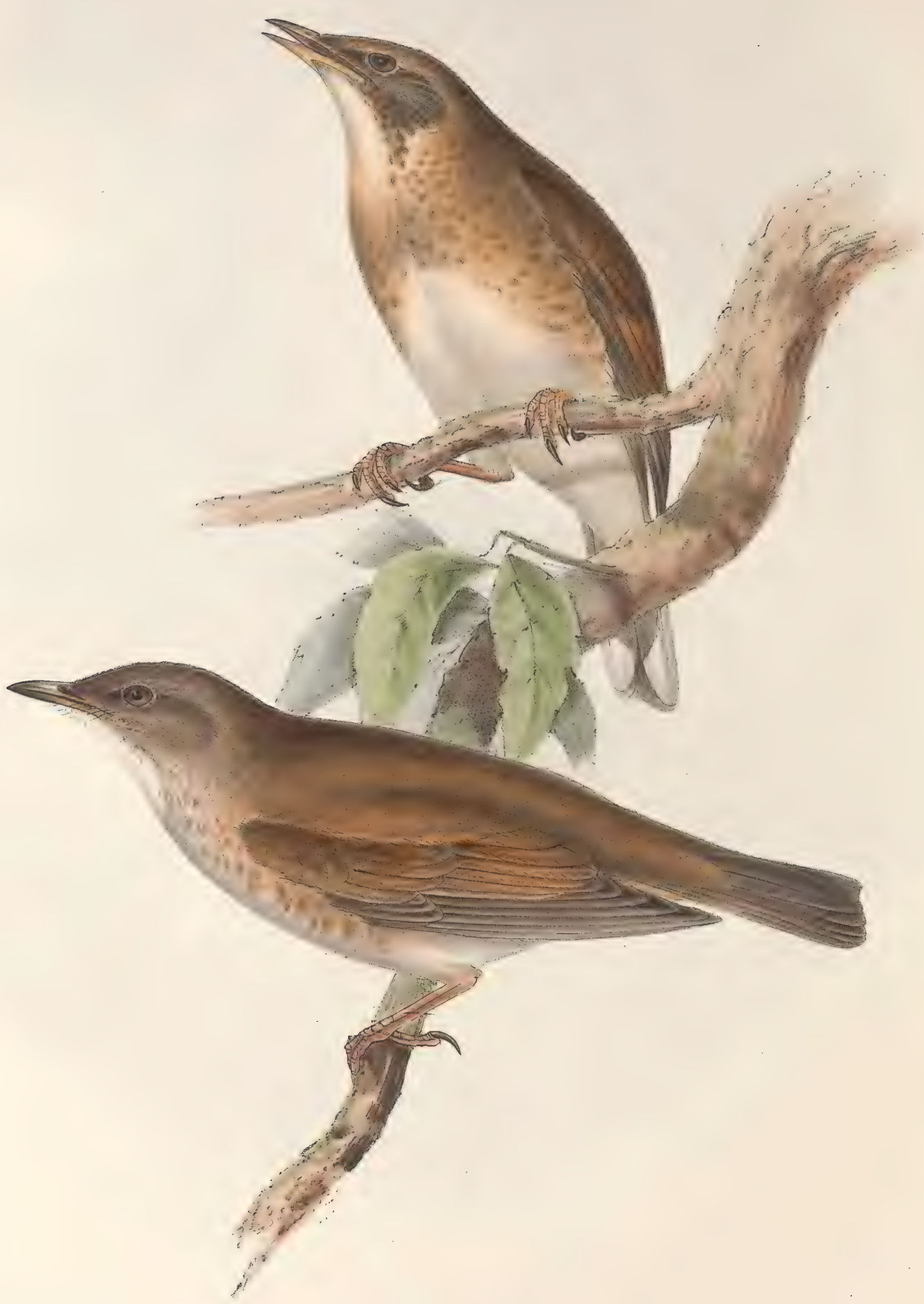

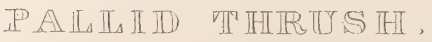

Turdus pallidus; / Pall., 


\section{PAILID THRUSH.}

Turdus pallidus, Pall.

Le Merle blafard.

The claim of this bird to a place in the Fauna of Europe, says M. Temminck, (from whom we received the specimen from which our figure was taken,) is based on the capture of three individuals, one of which was taken in September 1823, near Herzberg in Saxony. It is one of the many discoveries made by Pallas, whose merits as a naturalist are too well known to require our praise.

Like the Turdus Sibericus this bird is extremely common in Japan, whence, through the kindness of M. Temminck, we have received several examples : it is also spread over the whole of Siberia, and occasionally passes the boundary line and visits the centre of Europe.

Of its habits, manners, and nidification nothing is known, but in these respects it doubtless closely resembles the other members of the genus.

The whole of the upper surface is of an olive brown; ear-coverts brown with a faint line of white down the centre of each feather; tips of the wing-coverts yellowish, forming a band across the wing; sides of the throat pale reddish brown blotched with white; chest and flanks pale reddish brown, the former ornamented with numerous spots of a darker tint; throat, centre of the abdomen, and under tail-coverts white; two outer tail-feathers largely tipped with whitish on their inner web; bill and feet light brown.

We possess other specimens in which the spots on the breast are wanting, and the white of the throat and abdomen is less pure; but whether this difference is occasioned by sex or age we are unable to determine.

We have figured the bird in both states of the natural size. 




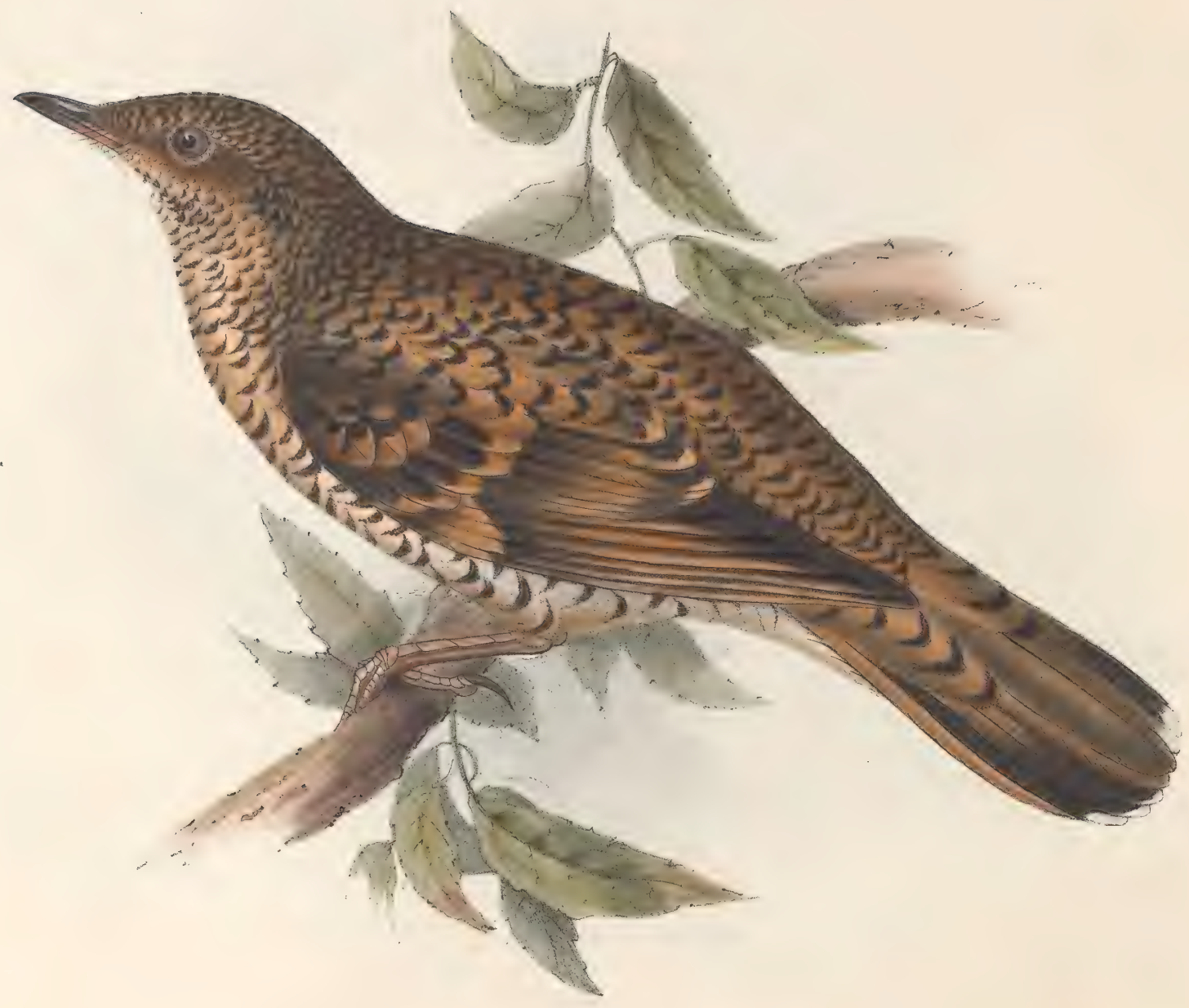

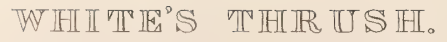

Turdus Whitei; (Eyton.) 


\title{
WHITE'S THRUSH.
}

\author{
Turdus Whitei, Eyton.
}

Le Merle de White.

ThreE specimens of this rare bird having been killed in Europe, two on the banks of the Elbe near Hamburgh, and a third which was shot by Lord Malmesbury at Heron Court in Hampshire, in January, 1828, we have deemed it necessary to include a figure of it in the present work.

While at Hamburgh we were fortunate enough to obtain one of the specimens taken there, from the person who had it, in a fresh state; this specimen now forms a part of the collection of T. B. L. Baker, Esq., of Hardwicke Court, Gloucester, who doubtless values it as one of the greatest rarities of his collection. Although we have placed this bird in the genus which comprehends the true Thrushes (the type of which is the Turdus musicus, Linn.), still we doubt not that this bird, with the Turdus varius of Dr. Horsfield and another from New South Wales, will be found to constitute a well-marked and distinct group among the Merulida. From the greater length of their wings, we are led to believe that these birds possess very considerable powers of flight, and that in all probability they are strictly migratory in their habits. When compared with the true Thrushes a considerable difference may be observed in the form and length of the tail, and also in the tarsi and toes.

In its general size the Turdus Whitei exceeds by almost a fifth the Turdus varius, while the bill is much smaller: the length of the wing in Mr. Baker's specimen of Turdus Whitei is six inches and three quarters, while that of the Turdus varius and of the species from New South Wales scarcely exceeds five inches and a half. The great difference in size and the smaller bill will be sufficient to establish the specific value of this fine bird, which has with much propriety been dedicated to the celebrated and kind-hearted White, whose work on the Natural History of Selborne is not only fraught with instruction, but has given a decided impetus to the study of this branch of knowledge in this country. This species is very common in Japan, and is in all probability dispersed over a great part of Southern Siberia.

Crown of the head, back of the neck, back, rump, and upper tail-coverts light yellowish brown, each feather tipped with a crescent-shaped mark of blackish brown; wing-coverts and tertiaries dark brown tipped with buffy brown; spurious wing dark blackish brown, crossed in the middle by a band of buff; primaries dark brown on their inner webs, and buffy brown on the outer; four central and two outer tail-feathers pale brown, the latter tipped with whitish; the remainder blackish brown; throat, centre of the abdomen, and under tail-coverts white; the remainder of the under surface pale buff, each feather passing into deep buff near the tip and terminating in a crescent of blackish brown; bill and feet light brown.

Our figure is of the natural size. 




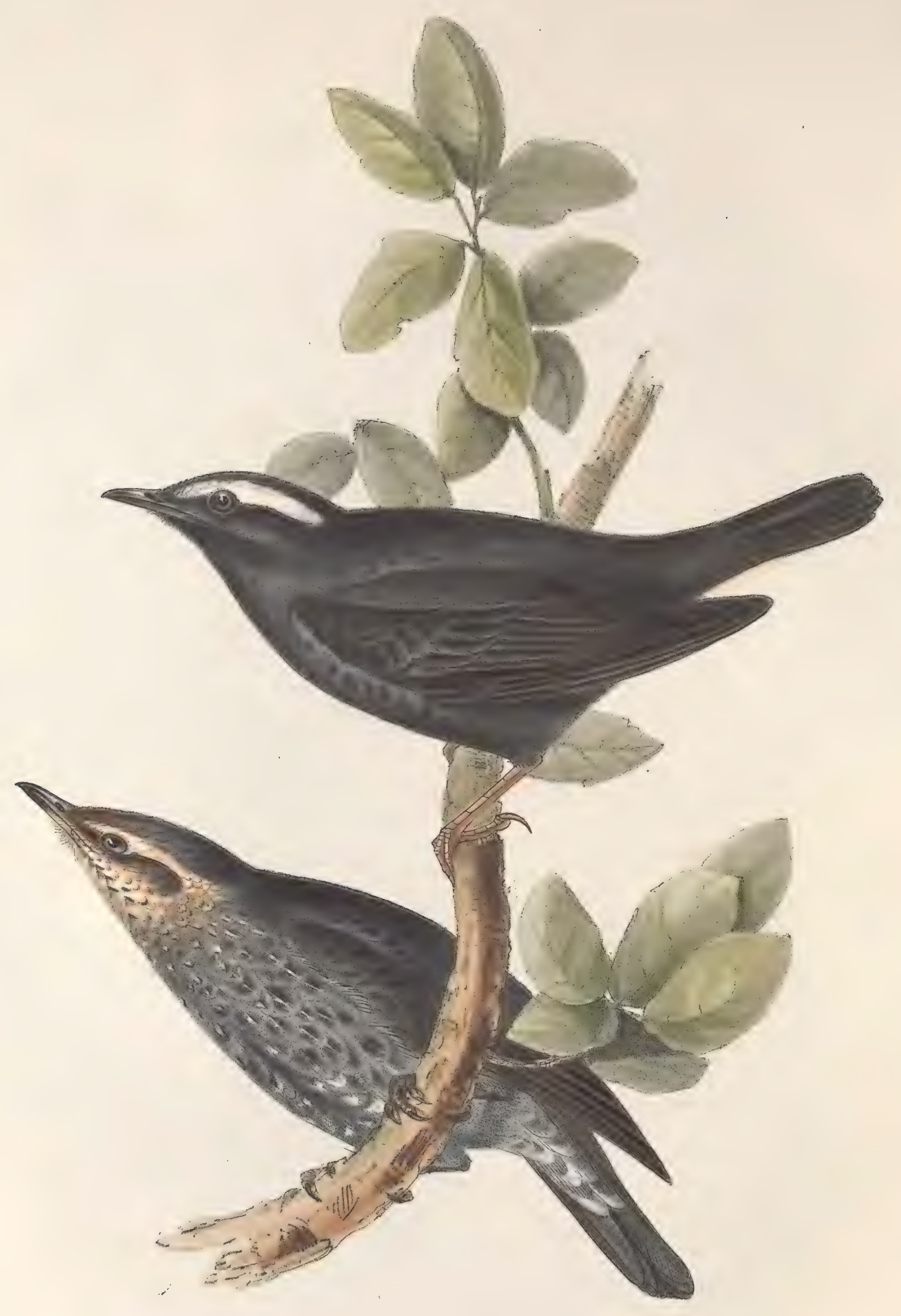

$S \mathbb{B} \mathbb{E} \mathbb{R} \mathbb{A} \mathbb{N} \quad$ TTHIRUS $\mathbb{S} \mathbb{H}$.

Turdus Sibericus; (Pall:) 


\section{SIBERIA N THRUSH.}

Turdus Sibericus, Pall.

Le Merle à sourcils blancs.

THus fine and rare Thrush was first described by Pallas as an inhabitant of Siberia, but on referring to the works of this author, his account of this species is so meagre that no information whatever is given relative to its habits and manners, except that, like the other members of the genus, it possesses considerable powers of song.

Were we more intimately acquainted with its economy, we doubt not that it would be found to differ in some slight degree from that of the common species, as from the peculiar silkiness and dark colouring of its plumage, together with its shorter tail, we cannot fail to observe a considerable difference in their form; and in all probability the Turdus Sibericus will prove to be the intermediate form connecting the members of the genus Petrocincla with the true Thrushes, especially if, on investigation, it should be ascertained that the bird evinces a partiality for rocky situations.

From Siberia, where it inhabits the wooded mountains, it has been known occasionally to stray into Russia and the Crimea, and hence it becomes necessary to add it to the list of European birds. Besides these localities we can also state that it is a very common bird in Japan.

The female may be readily distinguished from the male by having a lighter-coloured head and neck, which, with the whole of the under-surface, is spotted much after the manner of the typical members of the genus Turdus.

The specimens from which our figures are taken were kindly forwarded to us by M. Temminck, and may be thus described:

Male : forehead, crown of the head, and nape deep black; over each eye a broad stripe of white; all the remainder of the plumage brownish black, each feather edged with slaty grey; bill and feet brown.

Female : forehead, crown of the head, and nape deep brown; chin and throat pale buff; sides of the face and neck and all the under surface slaty grey irregularly spotted with buffy white; tips of the feathers on the centre of the abdomen, vent, and under tail-coverts tipped with dull white; primaries and secondaries brown; the remainder of the plumage as in the male but lighter.

We have figured an adult male and female of the natural size. 




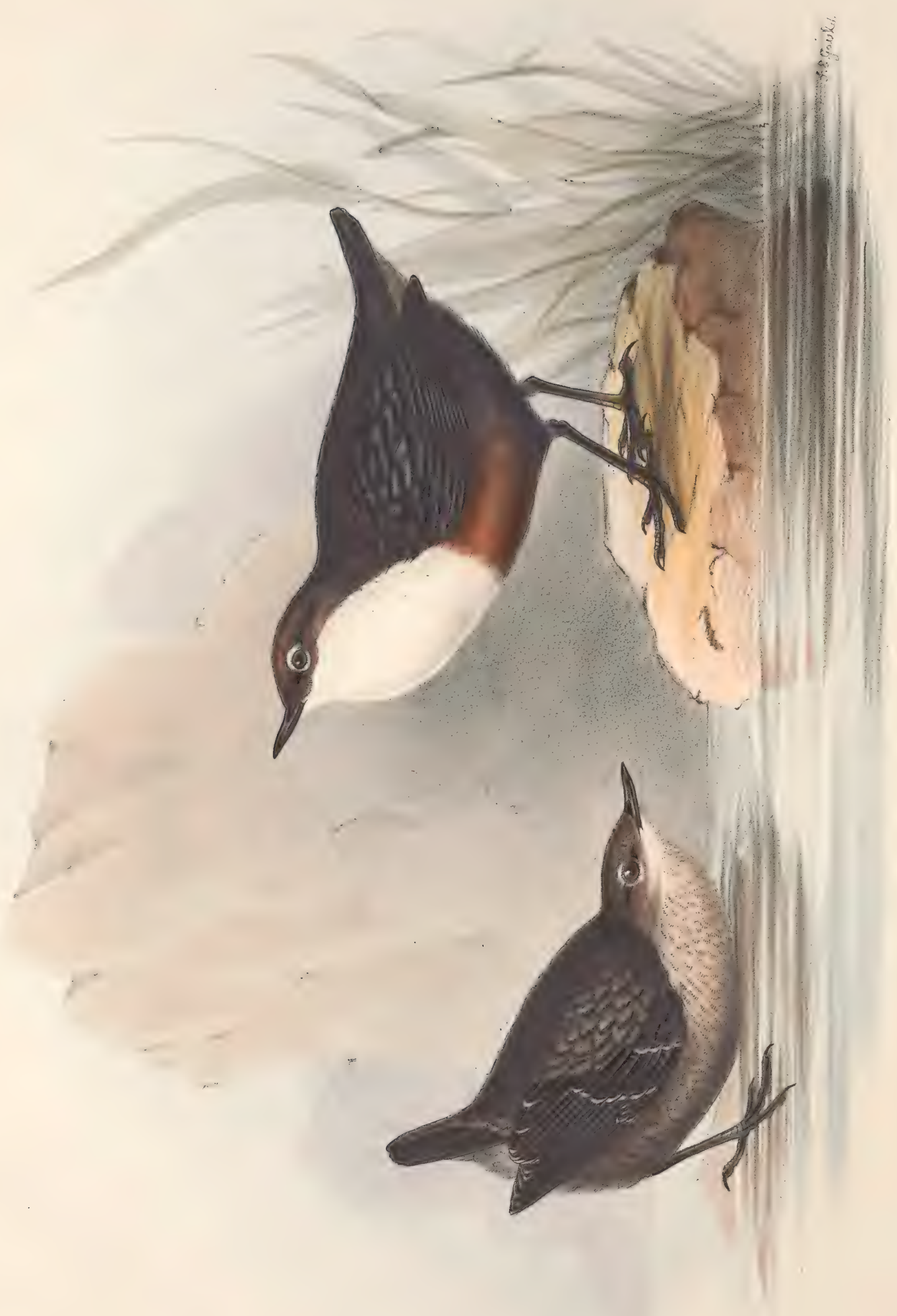

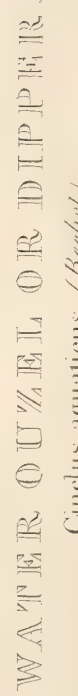




\section{Genus CINCLUS.}

GEN. Снаг. Beak slender, slightly bent upwards, compressed, cutting edges bending inwards; upper mandible notched at the tip. Nostrils at the sides of the base, naked, cleft lengthwise, partly covered by a membrane. Legs short; toes three before, one behind, the outer toe joined at its base to the middle one. Wings short; the first quill not half the length of the second, which is also shorter than the third and fourth.

\section{WATER OUREL。}

Cinclus aquaticus, Bechst.

Le Cincle plongeur.

THE genus Cinchus, as far as our knowledge at present extends, is very limited, including only three species, of which one is a native of the Himalayan mountains, another of Mexico, and the third (the subject now under consideration,) is peculiar, we believe, to Europe, where it is dispersed among the mountainous districts of the Continent and also of our own island.

The lonely, secluded, and indeed local situations in which this bird resides, have prevented our becoming familiar with its habits and manners, which, from their extraordinary and novel character, merit a more strict attention than they have hitherto received. We here allude to the power which the Water Ouzel possesses of diving and remaining submersed beneath the water while in search of food,-habits which, though they have generally attracted the notice of naturalists, have not received that close and philosophical scrutiny which the subject deserves; and we would recommend, to those who have the opportunity, a close study of this bird in a state of nature; for, however unqualified it may appear to be for such habits, it is undoubtedly capable of descending to the bottom of streams and rivers, for the purpose of prosecuting its search after insects and larvæ which are the inhabitants of the stony bottoms of mountain streams.

As far as the fact of its submersion goes, we have ourselves many times witnessed it; but have never been able to mark unobserved the actions of the bird under water, so as to say whether it is by a powerful effort that it keeps itself submersed, or whether it is completely at its ease as some have asserted.

The Water Ouzel is a spirited and restless little bird, full of life and activity, flitting from stone to stone along the borders of streams; and it is especially fond of perching upon any rock that happens to be elevated in the centre of the current, where, conspicuous by its white breast, it may be observed dipping its head and jerking its tail in a manner not unlike that of the Wren, at one moment pouring forth a lively twittering song, (and that even in the depth of winter, when the earth is covered with snow, ) and at the next diving down, and rising again at a considerable distance. When so disposed, its flight is straight, low and rapid,-in fact, much like the Kingfisher, and it is equally solitary in its habits. It is, however, seldom found in the same situations as the Kingfisher, the latter being a frequenter of streams which flow through a fertile country, while the Water Ouzel is peculiar to the rapid and limpid streams which descend the mountain sides, and run through glens at their base.

This interesting little bird builds its nest in the fissures of the rough stones and ridges which are common in such localities, and among the large loose stones of the margin. The nest is ably constructed of the various mosses and grasses nearest to hand, and covered with a dome, like that of the Wren: the eggs are from five to seven in number, of a pure and delicate white. The birds having arrived at maturity, neither undergo any peculiar changes in the plumage, nor exhibit external sexual differences. The young, however, are more brown on the upper surface, and the white extends over the whole of the abdomen, interrupted by little markings of brown, which become darker as they proceed.

In our islands we must look for the Water Ouzel in Wales (where we had the pleasure of obtaining the individuals from which the figures in the accompanying Plate were taken), Derbyshire, Yorkshire, and all the northern hilly counties. On the Continent it is extensively spread among the alpine and mountainous districts from Russia to Italy.

The upper surface is of a strong blackish brown, each feather having its outer edge black; the throat and chest are pure white; the abdomen rufous; the beak black; irides hazel.

Our Plate represents an adult, and a young bird of the year, of the natural size. 




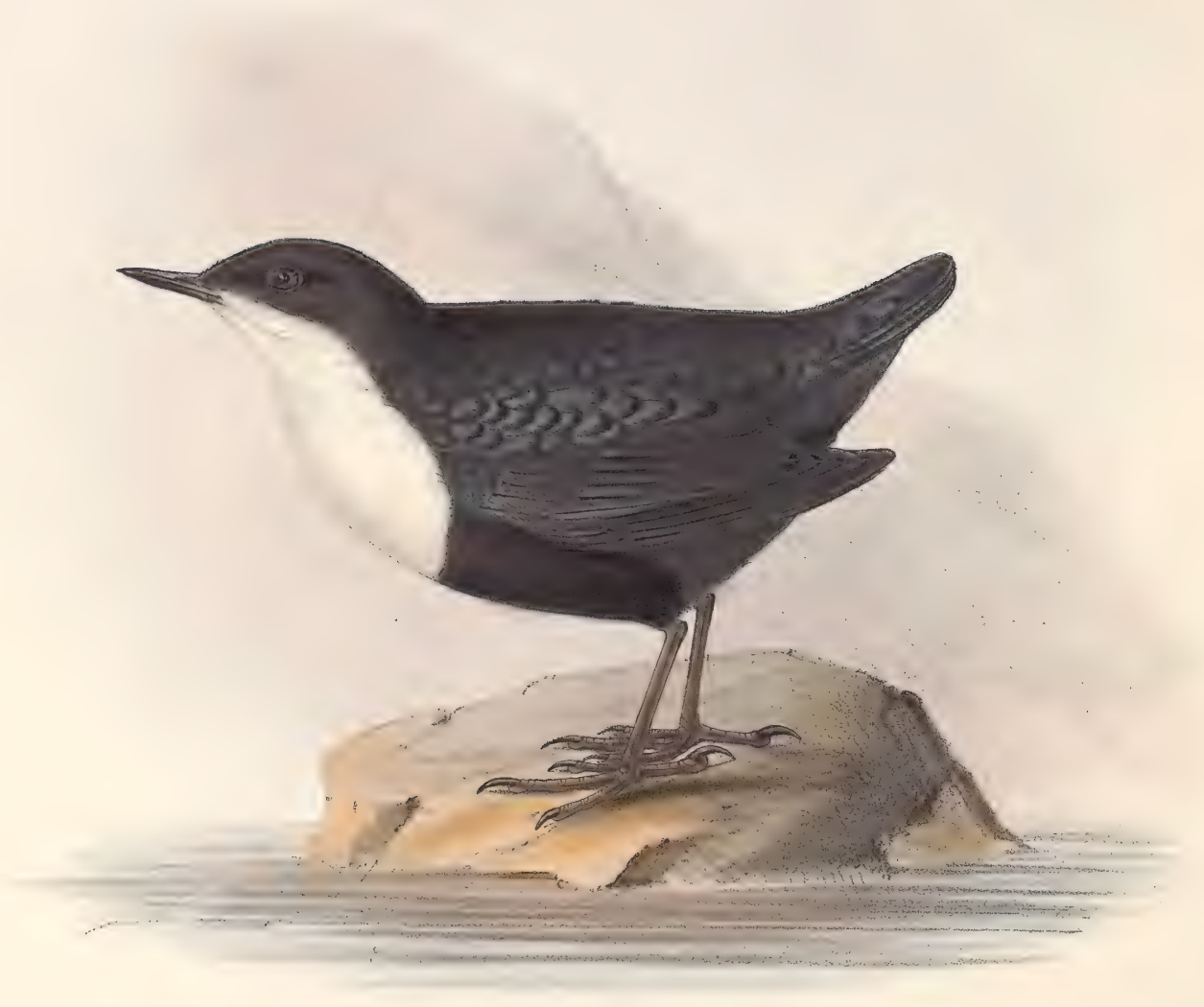

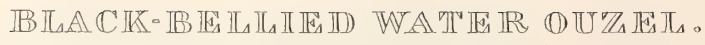
Cinclus melanogaster; (Temm: 


\section{BLA CK-BELLIED WATER OUZEI.}

Cinclus melanogaster, Brehm.

La Cincle à ventre noir.

A specimen of M. Brehm's Cinclus melanogaster having been transmitted to us by M. Temminck, we have ventured to give a figure of it, although we agree with the latter gentleman in questioning its specific value; it therefore remains for a future knowledge of its habits and manners to decide whether it may be considered as distinct, or only a variety dependent upon difference of climate and locality. In its general size and relative admeasurements it is rather less than the common species (Cinclus aquaticus), and is of a deeper colour both on the upper and under surfaces. According to M. Brehm it inhabits the north-eastern parts of the Continent, visiting in very severe winters the coasts of the Baltic, and is neither shy in its habits nor distrustful of the presence of man.

Its food consists of insects and their larvæ.

The head, back of the neck, and all the under surface deep chocolate black; the feathers of the back dark grey in the centre, with broad black edgings; wings and tail black; throat and chest white; feet dark brown; bill blackish brown.

We have figured an adult of the natural size. 




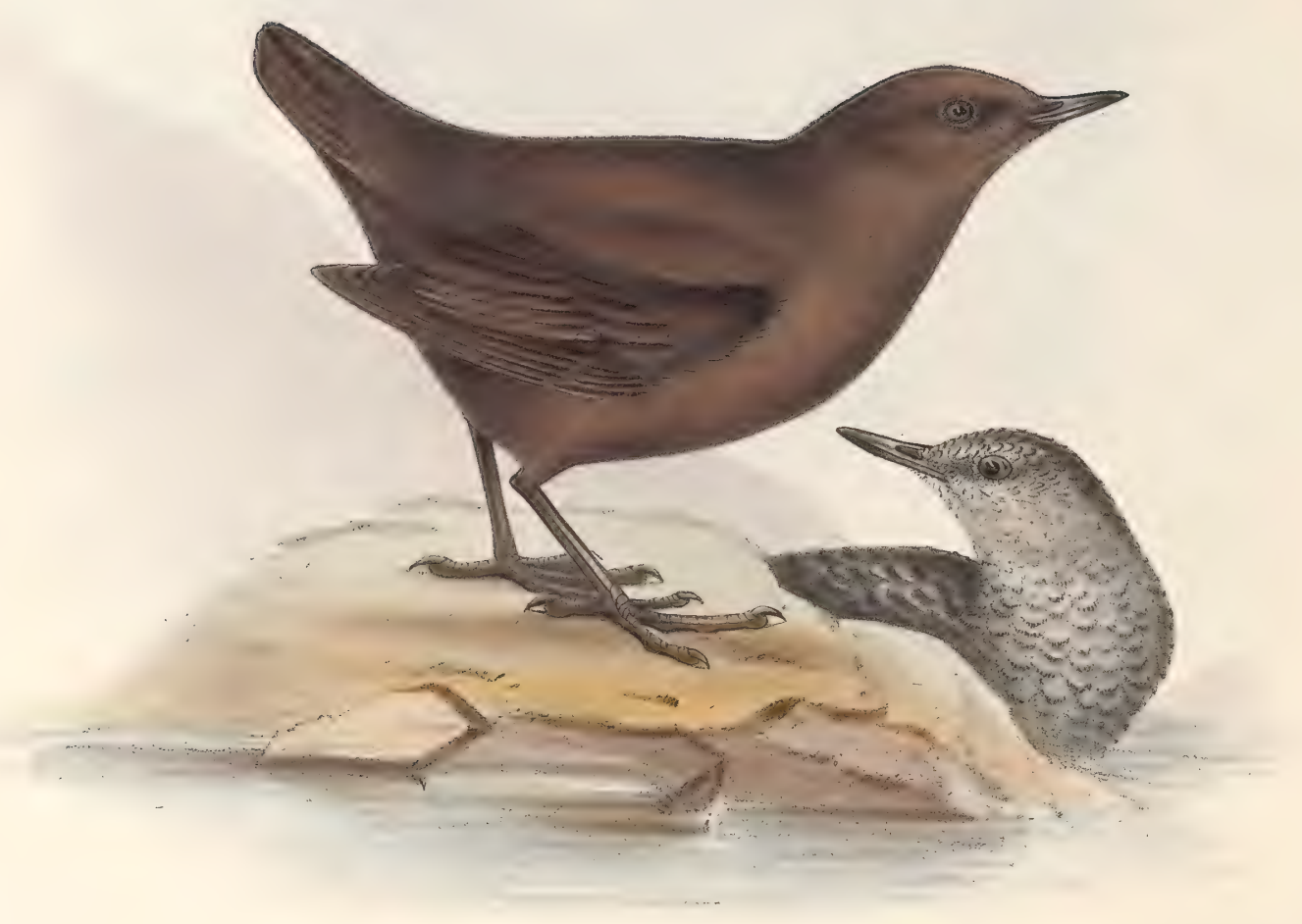

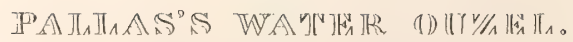

Cinclus Pallasii; (Temm) 


\title{
PALLA S'S WATER OUZEL。
}

\author{
Cinclus Pallasii, Temm.
}

La Cincle de Pallas.

IN the third part of his 'Manuel d'Ornithologie,' we find M. Temminck has included this rare species of Water Ouzel as an occasional visitant to the eastern confines of Europe, more particularly the Crimea and those portions of European Russia contiguous to the Asiatic continent. In our 'Century of Birds from the Himalaya Mountains' will be found a figure of this species as an inhabitant of the glenny streams of that fine country. Since the publication of that work we have received specimens of the young, as well as additional examples of the adult, and our present Plate is consequently rendered more complete and of greater interest by containing a representation of the bird in its young state, which on comparison will be found to possess a plumage very similar to that of the common species (Cinclus aquaticus). In the specimen from which our figure was taken, and which had nearly attained its full size, there was not the slightest trace of the chocolate colouring which characterizes the adult; in all probability therefore the change is effected by a total loss of the feathers early in the following spring, or at the second moult.

M. Temminck has favoured us with specimens of the Japan Water Ouzel, which differ so slightly from those killed in India as not, in our opinion, to admit of their being separated; it may be observed, however, that the Japan specimens are rather darker in colour, and that this difference is even perceptible in the young of the two species.

Whether the Cinclus Pallasii offers any material difference in its habits and manners from those of the British Water Ouzel we are unable to state, but in all probability they are very similar.

The adult is of an uniform chocolate brown, with the feet and bill black.

The young has the whole of the plumage of a fuliginous grey with numerous crescent-shaped markings of pale greyish white, which are most numerous on the throat, giving it a whitish appearance; feet and bill black.

We have figured an adult and a young bird of the natural size. 




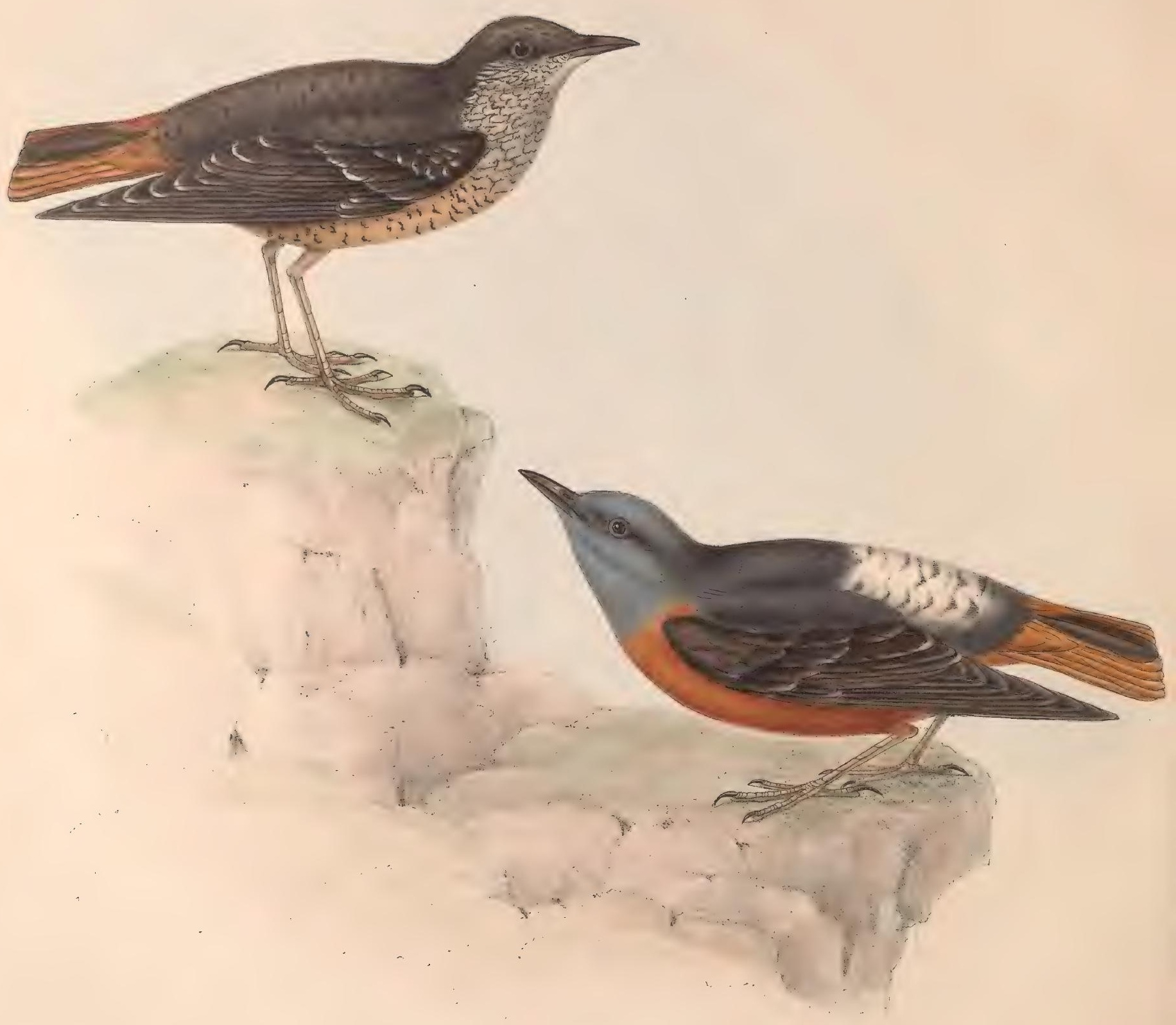

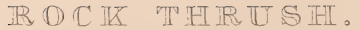

Petrocincla saxatilis, (Tig.). 


\title{
Genus PETROCINCLA.
}

Gen. Char. Beak stout; straight, the ridge arched at the point. Nostrils basal, round, partly covered with hairs. Wings of middle length; the first quill-feather very short, or almost spurious, the third the longest, the second a little shorter. Feet moderate, somewhat strong; the acrotarsi and paratarsi perfect. Tail equal.

Type of the genus, Turdus saxatilis, Linn.

\section{ROCK THRUSH.}

\author{
Petrocincla saxatilis, Vigors.
}

Le Merle de Roche.

THE Rock Thrushes, of which the present may be taken as a good example, differ so much from the more typical birds of the family, in form as well as in habits, manners and the localities they frequent, as to justify their being raised to the rank of a genus. This was hinted at by M. Temminck, who formed them into a section, which section has been subsequently established as a genus by Mr. Vigors, under the name of Petrocincla.

These birds, instead of dwelling in groves and woods, - a circumstance which so peculiarly characterizes the Thrushes in general,-affect the rugged and inaccessible declivities of rocks and mountains, for which their form is adapted; the shortness of their tails and the length of tarsi indicating them to be among those birds which live more exclusively on the open ground. In many respects they manifest a relationship to the Saxicolee, between which and the rest of the Merulide they seem to constitute a link of union, forming also a close alliance with various groups of ground Thrushes from other portions of the globe.

The present species is an inhabitant of the central and eastern portions of Europe, confining itself almost exclusively to the rocky and mountainous districts, especially the Alps, the Apennines, the Pyrenees, and some of the higher mountains in France. In such situations it incubates, constructing a nest of moss and herbage in clefts of the rock, among masses of loose stones, or in old ruins, laying four eggs of a pure greenish blue. M. Cuvier, in the short notice he gives of this bird in his Règne Animal, states that the male is distinguished by its beautiful song ; but into any minute details respecting its manners and peculiarities, we do not profess ourselves able to enter, and it is a matter of regret, that those who have had so many opportunities of becoming acquainted with its habits, \&c., in its native haunts, should have given us such meagre accounts respecting them.

The examples which have come into our hands prove it to be a species that undergoes several remarkable changes of plumage, which we cannot better explain than by availing ourselves, in our text, of the description given by M. Temminck, who appears to have paid a close attention to the subject.

"In the adult male, the head and neck are of an ashy blue, darkening on the upper part of the back into black clouded with blue; below this a large white space extends as low as the upper tail-coverts, which are also black. The shoulders black; the quill-feathers dark brown; the tail ferruginous red, except the two middle feathers, which are rufous brown; the chest and whole of the under surface bright ferruginous, each feather, especially those of the inferior tail-coverts, being obscurely tipped with white; beak blackish ; legs brown. Length seven inches and a half."

"The females have the whole of the upper parts brown; on the back are several large whitish markings bordered with brown; the throat and sides of the neck of a pure white;" but it often happens that the feathers of that part are edged with ashy brown; the rest of the inferior surface is of a reddish white, with fine transverse bars at the tip of each feather; tail of a light red, with the two middle feathers of an ashy brown.

The young of the year are, again, altogether different. The whole of the upper parts are ashy brown mottled with whitish grey; the end of each feather marked with a white spot; the quill-feathers and coverts are darker, the feathers forming the coverts having a grey border and whitish ends; tail red, lighter in colour at the extremity; the under parts very similar in colour to those of the adult female, but with more of white varied with red, and a multitude of irregular markings of brown.

Its food consists of Scarabæi and other insects, as well as wild berries.

Our Plate represents a male and female in full plumage. 




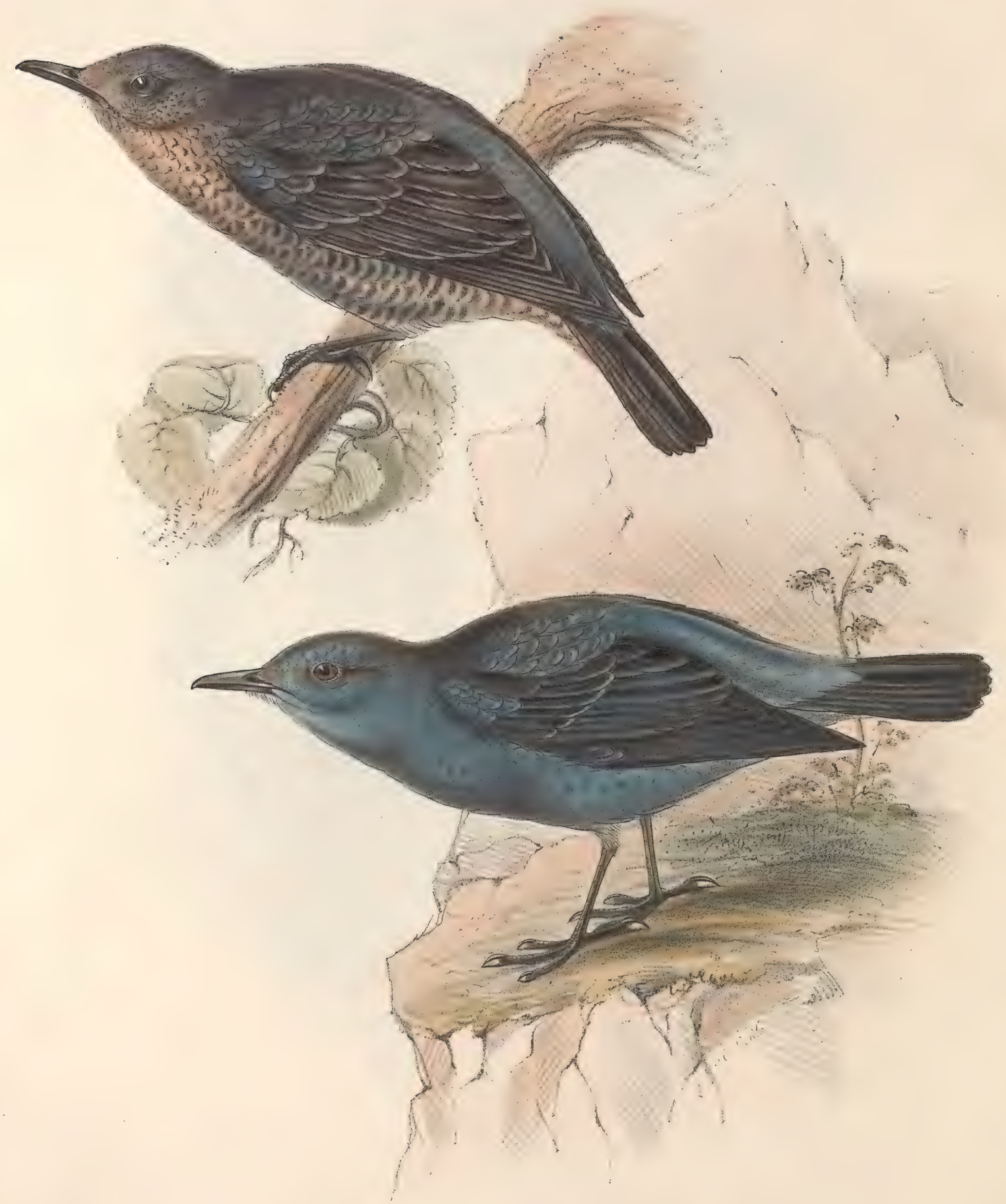

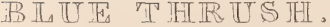

Petrocincla cyanus, / Vig.; 


\title{
BLUE THR U SH.
}

\author{
Petrocincla cyanus, Vig.
}

Le Merle bleu.

Like its congener, the Rock Thrush (Petrocincla saxatilis), the present species is a native of the rocky and mountainous districts of Europe, particularly towards the south, being very abundant in Piedmont and the Apennines, and also of common occurrence throughout Spain, Sardinia, Italy and the Levant. It is met with also in the South of France, but is rare in Switzerland. India and China produce a bird in every respect identical, with the exception of size, those which are received from Asia being considerably smaller than their European representative. Although the congenial habitat of the Blue Thrush is the rocky scenery of mountain chains, among which it breeds and remains throughout the year, still in many of its characters it seems to constitute a link between the more typical form of the genus Petrocincla and that of the true Thrushes, which latter it approaches in the proportions of the tarsi and tail. In the typical Petrocinclee, ( $P$. saxatilis, for example, ) the tarsi are strong and very elongated; but the tail is short, a conformation in harmony with strictly terrestrial habits. In the present bird, the tarsi are more moderate and the tail more developed; still, however, as its habits, style of plumage and general outline declare, it is in every sense a member of the genus in which it is now placed.

The Blue Thrush is shy and solitary, dwelling with its mate in the still and sequestered recesses of the rocks, in the clefts of which it builds its nest, though this is not always the case, as it often chooses the crumbling walls of lonely towers or buildings, and sometimes the holes of trees, in which to rear its young. The eggs are dull greenish white. Its food, like that of its congener, consists of grasshoppers, large insects in general, and wild berries.

The male and female exhibit considerable difference in their plumage, the young males of the year resembling the latter. In the adult male, the whole of the upper surface is of a deep greyish blue, many of the feathers being margined with grey; the wings and tail are black; the under surface is of a lighter blue than the upper, with obscure narrow bars of brown edged with white on the chest and abdomen; the beak and tarsi are black.

The female has the whole of the upper surface brown, obscurely barred with ash colour; the wings and tail blackish brown, each feather having a blueish margin ; the throat light brown, the feathers tipped and edged with black; the chest and under surface varied with light brown, grey and black, in pointed scales and transverse bars.

The young males may be seen in various stages between this style of colouring and the rich blue of the bird in its maturity.

The Plate represents a male and female in their adult plumage, of the natural size. 




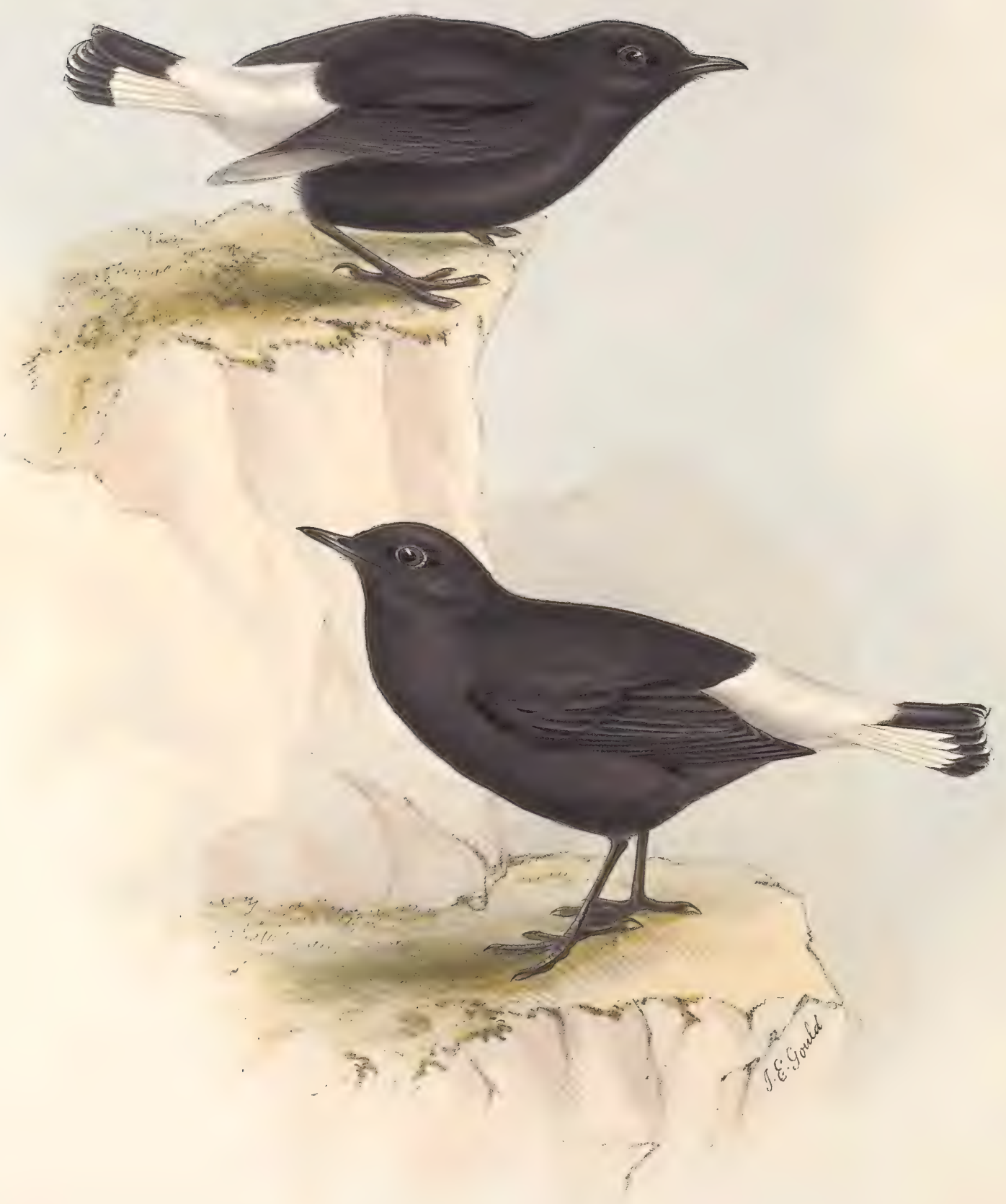

$\mathbb{B} \mathbb{I}_{\Delta} \mathbb{A} \mathbb{C} \mathbb{K} W \mathbb{H} \mathbb{E} A \mathbb{P} \mathbb{E} \mathbb{A}$.

Saxicola cachinnans; (Temm) 


\title{
BLA CK WHEATEAR.
}

\author{
Saxicola cachinnans, Temm
}

Le Traquet rieur.

Althougr the most proper situation for this fine species is doubtless among the true Wheatears (Saxicola), yet its greater size, robust bill, and more short and rounded wings, indicate a departure from the typical form, and an approximation to some other group, which at present we have not been able distinctly to make out; we suspect, however, that the group to which it will ultimately be found to lead is one of the terrestrial division of the family of Merulida. Though one of the birds of Europe, we cannot include it in our native fauna : it, is indeed, confined to the southern portions of the Continent, and is common at Gibraltar, where it is known annually to breed; it is also found in all the rocky and arid districts of Spain, Sicily, and the islands of the Mediterranean, as well as on the opposite coast of Africa. Judging from its form alone, we should be led to consider that the present species is not migratory, a supposition which is confirmed by its being a resident in countries where its food is ever abundant, and by its never having been known to visit the more northern districts of Europe, to which the Long-winged Wheatears are periodical visiters. We have said, that the present species is an inhabitant of the northern coast of Africa, which country also produces another closely allied to it, differing only in having a more lengthened wing, and the top of the head of a pure snow white. These two birds are by many ornithologists considered as one species, and that the white-crowned one is the adult of the present bird. We have ourselves carefully examined both these birds, and have no hesitation in declaring that they are truly distinct, differing not only in colour, but in relative admeasurements, the white-crowned species having a body of the same size, but a wing nearly an inch longer, being in all respects a typical Wheatear. Whether this African species is also a native of any part of Europe, we have as yet had no opportunity of ascertaining. The confusion between the two species has evidently arisen from the circumstance, that the young of the white-headed or African species does not possess the white on the top of the head, and in this state cannot, except by a narrow scrutiny, be distinguished from the young or the female of the true Saxicola cachinnans.

In its manners, the Black Wheatear is shy and timid, avoiding the presence of man, and confining itself to arid rocky places, where it is rarely disturbed by his presence. Its food consists of insects, beetles, \&c.

The general plumage of the male is black; the rump white, as are the tail-feathers, except at their tips, which with the whole of the two middle feathers are black; beak and tarsi black; irides dark brown.

The female resembles the male in the distribution of her colours, but the black is much less pure and strongly inclines to brown.

The young resemble the female in their plumage.

We have figured an adult male and female of the natural size. 



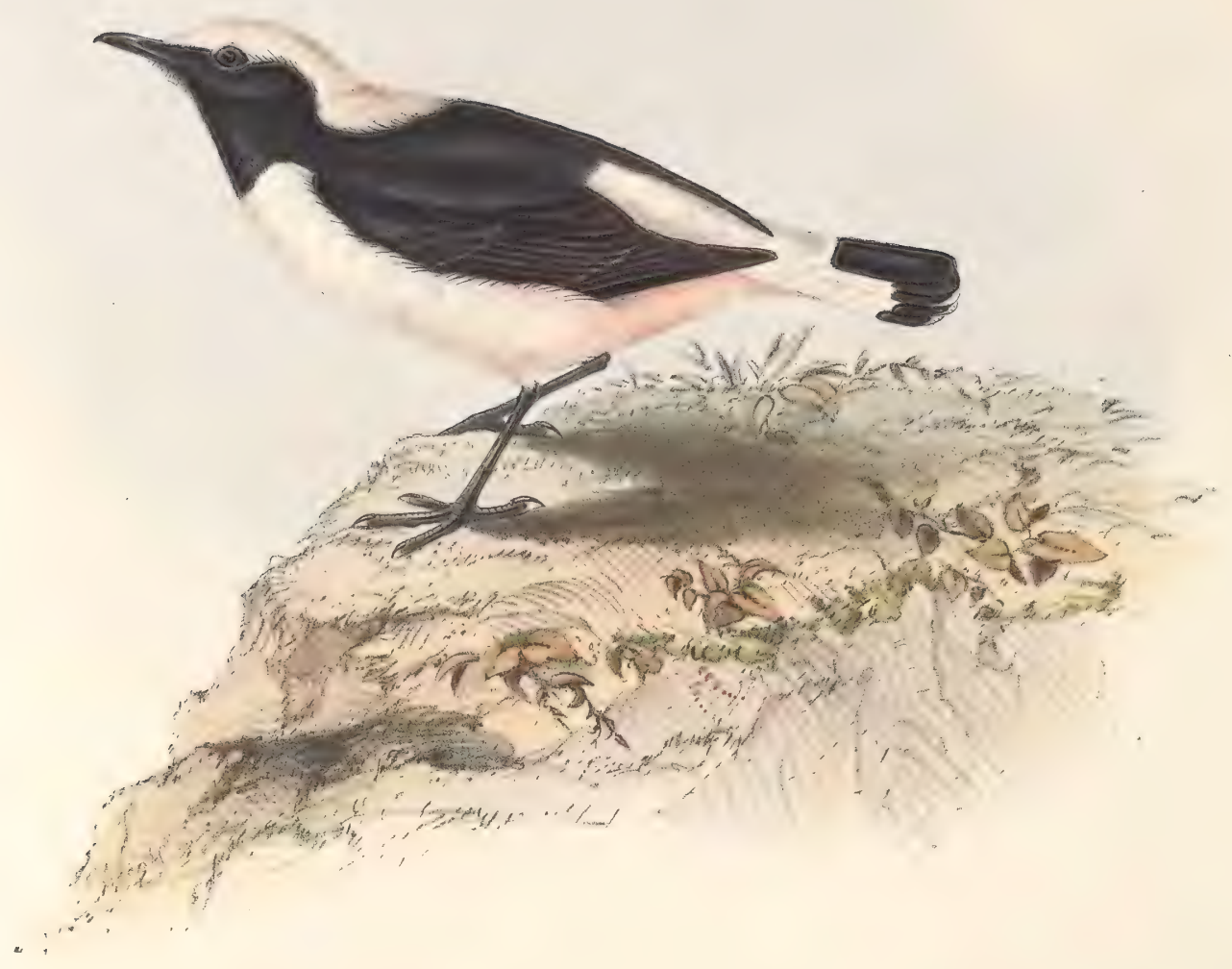

$\mathbb{P}$ II $\mathbb{E} \mathbb{D}$ WJHI $\mathbb{E} \mathbb{A} \mathbb{T}_{\mathbb{A}} \mathbb{A} \mathbb{R}$ 。

Saxicola leucomela; (Temm:) 


\section{PIEDWHEATEAR.}

Saxicola leucomela, Temm.

Le Traquet leucomèle.

While the downs, commons, and barren heaths of our island are enlivened by the presence of the Common Wheatear (Saxicola Enanthe, Bechst.), and the plains and deserts of Spain, Italy, and the southern districts of Europe in general are equally so with Saxicola aurita and stapazina, the northern portions, which include Russia and Lapland, are to be enumerated among the places in which the present fine species habitually takes up its station; and although so little is known respecting the natural habits of this bird as to leave us in a state of uncertainty regarding its migration, as well as the localities it chooses in which to incubate and rear its young, yet we may reasonably suppose that its general economy is in strict unison with that of its congeners. The Manuel of M. Temminck informs us, that so exclusively boreal is this species that it is never seen in temperate climates; which circumstance will lead us to infer that Siberia, Upper Tartary, and the most northern portions of Asia will hereafter prove to be countries of which nature has destined this bird to be a native, and the limited numbers which occasionally visit Europe to be individuals traversing the outer limits of their appointed range.

The female we have never yet seen; her colouring, however, will be readily understood when we state that where the male is black, the same parts in the opposite sex are of a dull brown; and the parts which are white in the former are of an obscure light brown in the latter.

It is said to construct a nest in rocks and old buildings, sometimes on the borders of rivers : of the number and colours of its eggs nothing is at present known.

The adult male has the top of the head, back of the neck, rump, base of the tail, breast, and under parts, with the exception of the vent, which is light rusty brown, of a pure white; the rest of the plumage being of an equally fine black, thus forming a strong contrast; legs and bill black.

The Plate represents an adult male of the natural size. 




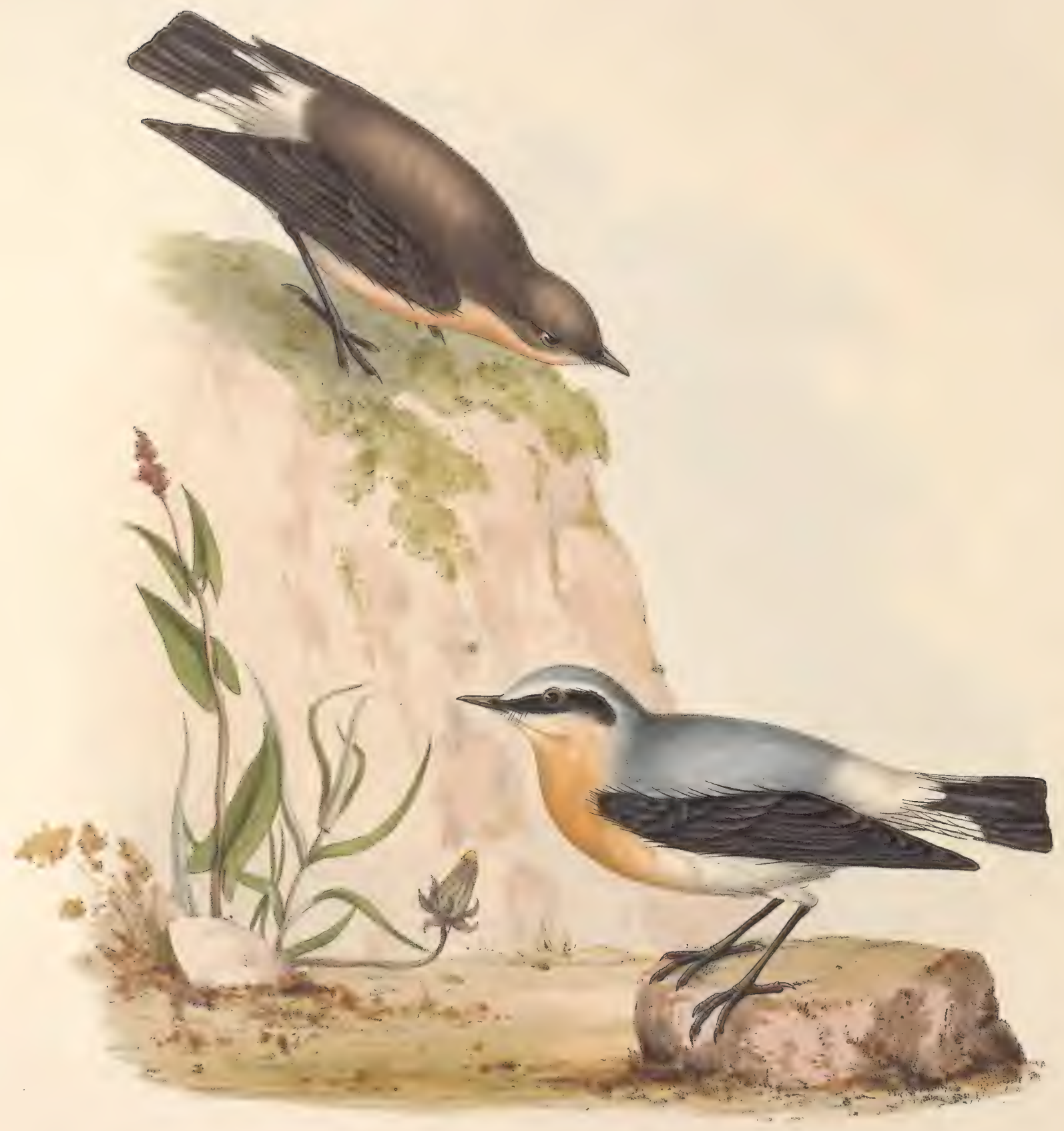

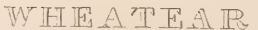

Saricola cenanthe./Beched). 


\title{
WHE A TEAR.
}

\author{
Saxicola Enanthe.
}

Le Traquet moteux.

The Wheatear is one of the summer migratory birds which annually visit the British Islands, arriving in March, when it disperses itself over wild heaths, moors, fallow grounds, and rabbit warrens, making a nest of moss and vegetable fibres, lined with hair or wool, generally in a hole on the ground or among loose stones, but not unfrequently in the cleft of a rock or at some distance in a deserted rabbit burrow, and laying five or six eggs of a uniform pale blue. The extreme delicacy of the Wheatear has caused it to be much sought after as a luxury for the table, for which purpose incredible numbers are annually taken. Mr. Pennant, in his British Zoology, states that at Eastbourne, in Sussex, the number annually taken amounts to 1840 dozen. They are principally caught by shepherds, who from the nature of their occupation have every opportunity of studying the habits of this bird, so as to contrive the most successful mode of securing them, which is generally effected by nooses of horsehair.

In September, previous to their departure to the Continent, they make the downs of our southern counties a place for their general assemblage, where they wait for a favourable wind to carry them over the intervening channel.

In its habitat, the Wheatear is especially confined to open and bare grounds, seeking neither the covert of the furze nor the hedgerow, as is the case with the other British species of Saxicola,-a circumstance which, perhaps, in connexion with a trifling modification of form, has induced some authors, viz. Brisson, Stephens, \&c., to separate it from S. rubetra, the Stonechat, and the Whinchat, S. rubicoln, and advance it to the rank of a genus, to which they have given the name of Vittaflora, the propriety of which we leave to others to determine, as it is not so much our object to enter into the minutiæ of generic divisions, as to give a faithful portraiture and history of each species, with a view to their natural arrangement on comprehensive principles.

The Wheatear is a pleasing and elegant bird in its plumage; and its manners, though retired, are lively and active. Hopping and springing from clod to clod, and occasionally breaking out into short flights in pursuit of insects, it becomes conspicuous from the snow-white mark across the base of the tail.

Beside the softer insects which it captures on the wing, Coleoptera and their larvæ form its diet, to which worms, \&c., are also added.

Although not generally classed among our song birds, nevertheless the Wheatear is not without its vocal powers, warbling a soft and sweet strain, not unfrequently while quivering on the wing a few yards from the earth : occasionally its notes rise to a bolder and more elevated pitch; and when kept in confinement, a matter of no great difficulty, it charms us with its simple song, continued through the depths of winter.

In the adult male, the bill is black; the irides dark hazel; from the base of the bill a white line extends over each eye, and beneath it a broad black band passes which includes the orbits and ear-coverts ; upper part of the head and back cinereous gray; rump and tail-coverts white; the two middle tail-feathers black; the rest black two thirds of their length from the base; wings blackish brown; each feather edged with a lighter rust-coloured border; throat and neck beautiful buff, becoming lighter as it proceeds downwards ; tarsi black.

In the female, the under parts are brown; the forehead inclining more to gray ; the black parts in the male, including the mark across the eye, are here exchanged for deep brown; the edges of the wing-feathers are more or less ferruginous; the white at the base of the tail is less extensive, and the neck and chest are reddish, becoming lighter as it approaches the under surface.

The young of the year of both sexes somewhat resemble the adult female; but a tinge of red pervades the whole of the plumage, and especially the edges of the quill- and tail-feathers. Total length about six inches.

We have figured a male and female in their spring plumage. 




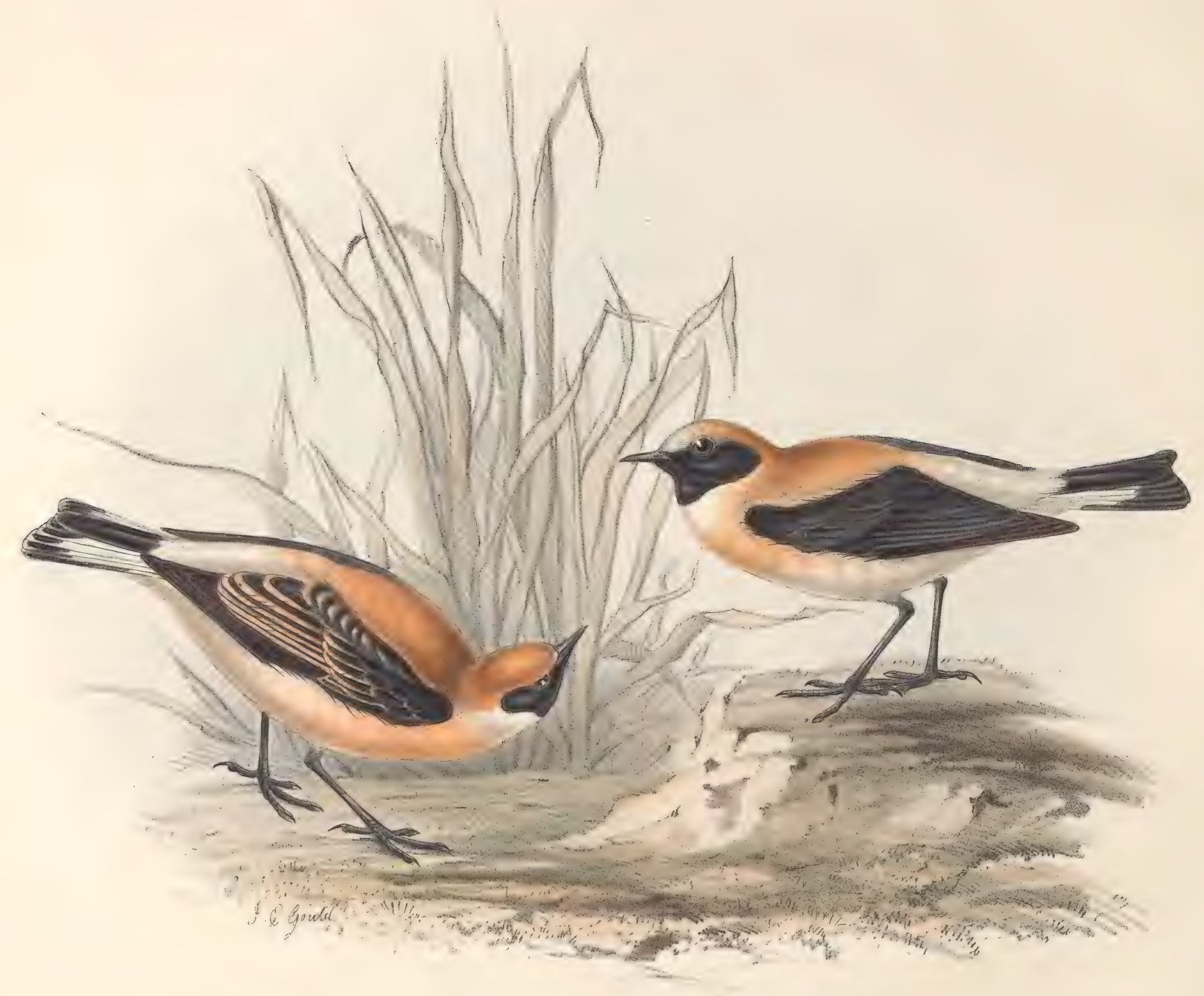

RUSSUTWWHA W W $\mathbb{A} \mathbb{A}$.

Saxicola Stapazina; ( $(\mathrm{emm}$ ) 


\title{
RUSSET WHEATEAR.
}

\author{
Saxicola stapazina, Temm. \\ Le Traquet stapazin.
}

In making the Saxicola stapazina a different species from the $S$. aurita, we rely not so much on our own observation as on the opinion of M. Temminck, who assured us personally that he had every reason for considering them as distinct species; and in his "Manuel d'Ornithologie" he remarks, that the European habitat of the S. stapazina is more limited than that of $S$. aurita, being restricted solely to the rocky borders of the Mediterranean, the South of Italy, Dalmatia and the Grecian Archipelago ; that it is rarely seen in the North of Italy, and never in the central districts of Europe. It is to be regretted, that in consequence of the peculiar localities in which alone this bird is found, our opportunities for studying it during its various changes are very limited : we have, however, exerted ourselves to obtain as many specimens as possible, and we now possess a series of examples, killed at different seasons of the year, upon which we rely for our description. Unlike the Common Wheatear, which exhibits so marked a difference in the plumage of the sexes, the Russet Wheatear, in the adult stage, differs rather in the purity than in the decided contrast of colours which distinguishes the male and female; but, like the Saxicolce in general, each sex, after the autumn moult, loses, by the gradual action of the air and light, as the spring approaches, the rich rufous tone of colouring by which the plumage is at first characterized, the tints becoming gradually paler and the black of the wings deeper, the brown tips of the feathers being worn off.

In habits and manners, the Saxicola stapazina is a true example of its genus, preferring, like the Wheatear, wide elevated downs, where it obtains its food, seldom perching upon trees, and never retiring to the woodlands for shelter. Of its nidification nothing positive is known.

In the adult plumage of spring, the male is thus distinguished. From the beak to the eye, and from thence over the ear-coverts, extends a band of black, of which colour are the throat, scapulars and quills ; the top of the head, the rump and under parts are pure white; the back of the neck and back are light rufous ; the tail white for three parts of its length and black at the tip, with the exception of the outer feathers, which are almost wholly black, and the two middle ones, which are quite so.

Immediately after the autumn moult, the top of the head and back of the neck have a shade of ash colour; the breast is reddish, gradually passing into white, and the black scapulars and quills are edged with rufous.

The young males of the year resemble the female, in which the tints are altogether of a redder hue; the dark feathers of the throat and region of the eyes being brownish black, the quills and coverts edged with reddish, and the breast reddish white.

The Plate represents an adult of the natural size just after the autumn moult, and a bird of the first year, killed at the same season, differing only in the rufous edging of the wing-feathers. 




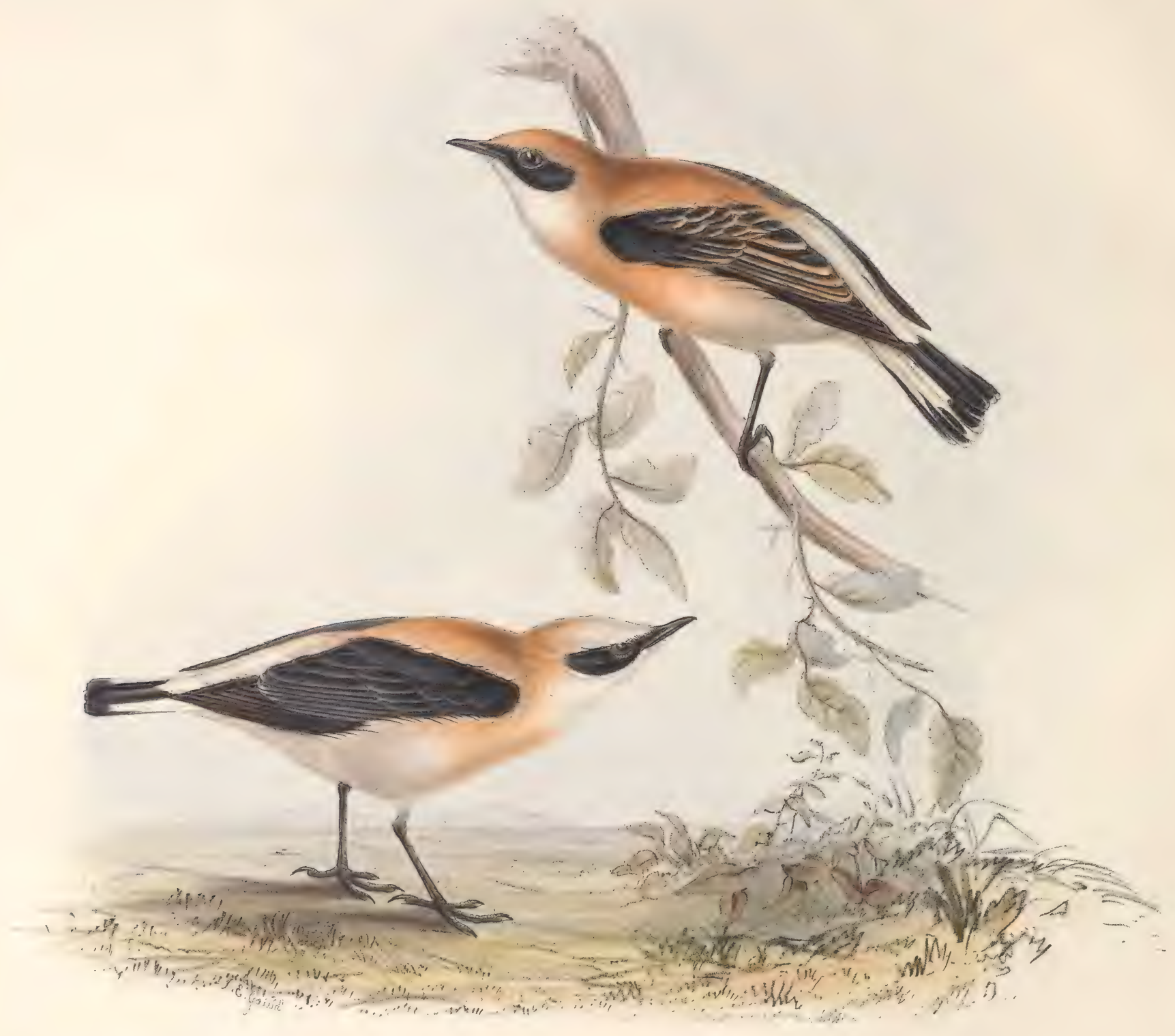

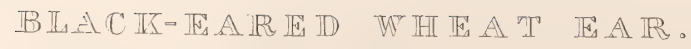

Saxicola aurita;(Temm.) 


\section{BL A CK - E A R ED WHEATEAR。}

Saxicola aurita, Temm.

Le Traquet oreillard.

IN a remark subjoined to a description of the Saxicola aurita, in M. Temminck's "Manuel d'Ornithologie," that learned naturalist observes, that had he not a thorough conviction of the distinction between this and the bird previously described by him, (S. stapazina, ) he should be ready to admit their specific identity, differing as they do in one point only, viz. the black throat of the latter being exchanged in the former for white or whitish rufous, the black band from the beak over the ear-coverts being alone retained: in the rest of the plumage the agreement is precise. For our own part, we confess, that were it not that M. Temminck expresses himself positively on this subject, and asserts that " the stapazina in its different stages has the throat and a part of the neck always of a deep black or blackish," we should have hesitated, the difference being less than is known to occur in many birds under the varying circumstances of age, sex, or season. We, however, follow the opinion of so distinguished an ornithologist, supported, as we doubt not it is, by positive proofs, - and therefore describe the species as truly distinct.

In habits and manners the Black-eared Wheatear agrees with its allied congener, inhabiting the hilly districts of the South of Europe : it is, however, more common in the North of Italy than the Russet Wheatear. Though in the centre of Europe it is never seen, the borders of the Mediterranean, the Apennines, Sardinia and the Neapolitan States are abundantly supplied with this species. Of its nidification we have no accounts upon which we can rely.

Adult male in spring: From the beak to the eye and thence over the ear-coverts extends a band of black; head and rump pure white; back of the neck and back light reddish brown; throat and under parts white; tail white for three parts of its length and tipped with black, excepting the outer feathers, which are nearly all black, and the two middle feathers, which are entirely so; wings black.

The adult female nearly resembles the male in all her markings, having the head and upper surface reddish brown ; throat whitish ; breast reddish, becoming lighter below ; rump white; and the wings blackish brown, each feather being finely edged with reddish.

After the autumn moult, the plumage exhibits the deep tints and rufous edgings to the feathers which characterize the preceding species at the same time. The young of the year differ little from the adult female, and exhibit only obscure traces of the ear-mark; but their plumage is more equally tinted with rufous.

The Plate represents an adult male in the spring and autumn plumage. 




$$
2
$$




\title{
W H I N C A T.
}

\author{
Saxicola rubetra, Bechst. \\ Le Grand Traquet.
}

Among the smaller migratory birds which visit us on the return of spring, the Whinchat is one of the most pleasing and elegant; it seldom, however, favours us with its presence before the middle of April, frequenting, in pairs, the pasture lands and commons of every part of England, but is more scarce in Devonshire and Cornwall, especially the western portions of those counties. Though not a distinguished songster, its simple and hurried notes are by no means unpleasing, and well accord with its active and sprightly manners. In some of its habits it is not unlike the Fly-catchers, perching on a stem of grass or dock, darting at the insects as they pass by, and returning again to its station. But its length of tarsi indicates the bare and open ground of meadows and commons to be its peculiar province; hence it is not found to frequent woods or thick coppices, as is the case with our songsters in general : shy and timid, it seldom allows itself to be approached, but with a quick and lively action flits forward to the next bush or elevation of earth, incessantly watching the intruder ; and, if again disturbed, repeating the same short flight ; still, however, keeping within the neighbourhood of its residence for the season, and where, on her sheltered nest, the female is carrying on the process of incubation. During this period the male bird displays great restlessness and apprehension if the nest be approached, flitting from spray to spray, jerking its tail repeatedly, and uttering its querulous note, which may be represented by the two syllables $u$-tick, the latter of which is frequently reiterated, and the whole note is sounded so distinct and clear as to be heard at a considerable distance. It builds its nest on or near the ground, and forms it principally of coarse grasses lined with finer fibres: the eggs are in general five or six in number, of a greenish blue, minutely speckled with light reddish brown at the large end.

The Whinchat seems to be universally spread over the northern portion of the European continent, its favourite localities being the same as in England, viz. mountainous heaths and extensive pasture lands.

Although a general similarity exists between the plumage of the sexes, the males may always be distinguished by their brighter and more strongly contrasted colours, and by the conspicuous white stripe over the eye and on the wing.

As the autumn advances and insects become scarce, the Whinchat dissappears, passing over to the more southern countries, and not improbably to the Levant, Syria, and the northern coast of Africa, where its supplies of insect food are still abundant.

In the male, the bill is black, furnished at its base with a few bristles; a broad black streak beginning at the bill passes through the eyes and covers the ear-feathers, above which extends another line of white; crown of the head, back, and wing-coverts of a dark brown, the edges of each feather being of a light ferruginous colour; chin white; throat and breast orange-brown; belly, vent and thighs pale buff; tail short, the bases of the outer feathers white, the rest black.

In the female, the streak over the eye is much less conspicuous; the cheeks instead of being black are of the same colour as the rest of the head; the general plumage is duller, the marks less distinct, and the white mark on the wing totally wanting; legs and toes black. Total length about five inches.

Our Plate represents a male and female. 




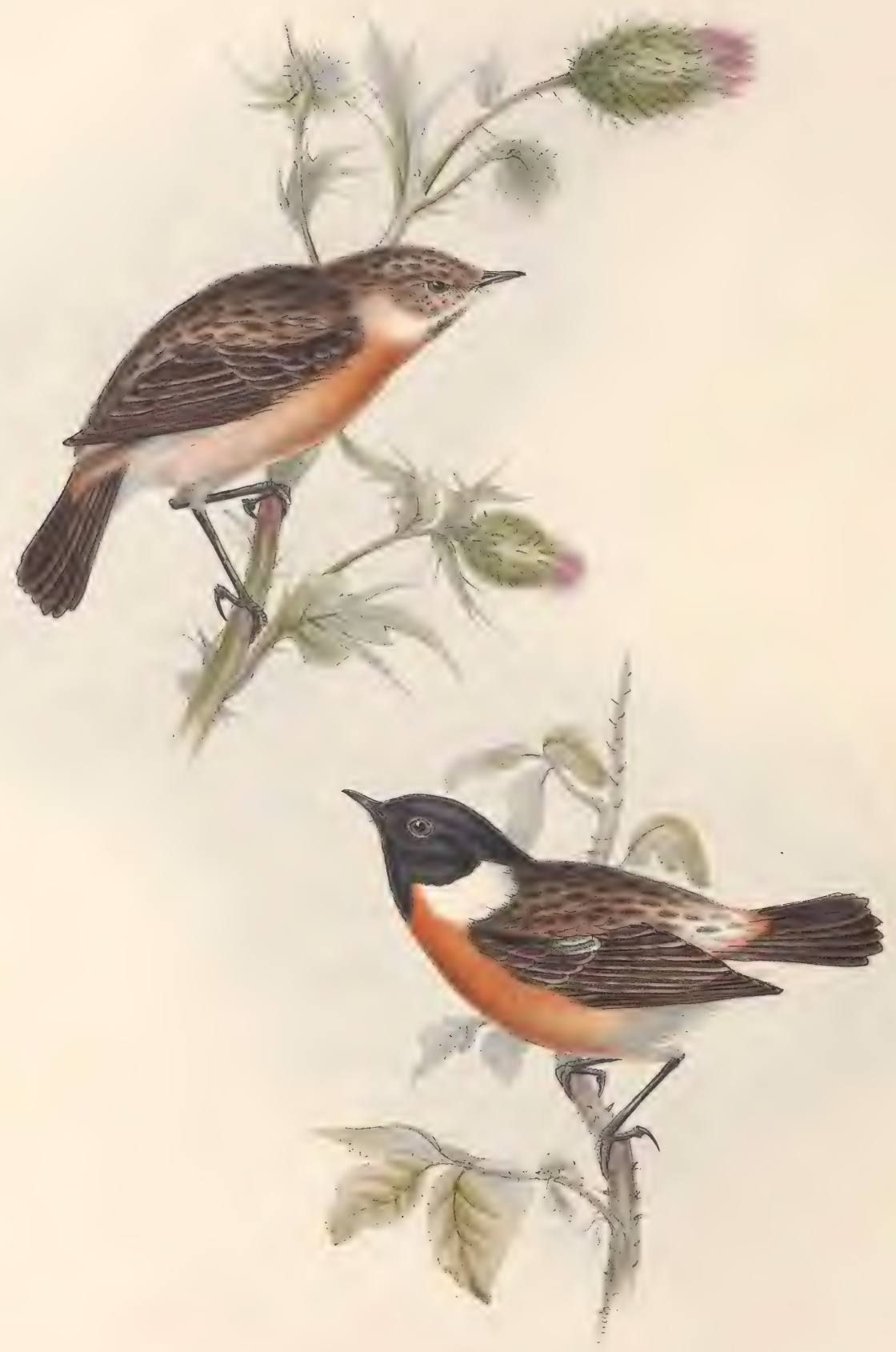

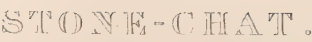

Saxicola rubicola (Becturt). 


\title{
ST ONE CHAT.
}

\author{
Saxicola rubicola, Bechst.
}

Le Traquet pâtre.

M. Temminck, whose knowledge of European birds cannot be questioned, states in his "Manuel d'Ornithologie," that the Saxicola rubicola is a bird of passage in Europe, but stationary in Africa: however this may be, it is certainly stationary in England, and may be observed at all seasons on commons, moorlands, and shrubby heaths, from one extremity of the British Isles to the other. It is a species possessing a wide range of habitat, as examples from India and Africa present no specific differences. Its habits and manners are somewhat in unison with its allied congener the Whinchat, but it is even more restless and noisy, flitting from bush to bush, or rock to rock, and not unfrequently perching on the tops of the flower of the thistle or highest twig of the whinbush, at the same time uttering its singular monotonous notes, which may be compared to the clicking of two stones struck together at repeated intervals.

The present bird and the Whinchat (Saxicola rubetra, Bechst.) present many points of difference, both in form and habits, from the rest of the genus : instead of being confined almost exclusively to the ground, as is the case with Saxicola ænanthe, stapazina and aurita, they give the preference to low bushes and shrubs, as above noticed, on which they habitually perch, constituting in this respect an intermediate grade between the genuine Saxicole and the true woodland Sylviadee, or rather, perhaps, the Muscicapidae (Flycatchers), which they resemble in the abruptness of their actions and in their manner of darting from their perch at insects on the wing, in pursuit of which they appear incessantly occupied. These, indeed, with larvæ and worms, constitute their food.

The Stonechat builds its nest at the bottom of bushes, or among the crevices of rocks : the eggs are pale green with a few blotches of light red.

The male and female offer a decided contrast in their colouring.

In the male, the head, throat and tail are of a deep black; the sides of the neck, the scapulars and rump of a pure white; the back deep black, each feather having a light reddish margin; wings blackish ; breast deep rufous, becoming paler on the under surface.

The female has the upper surface of a brownish black, each feather having a yellowish red border, as have also those of the wings and tail, which are brown; throat black slightly dotted with white and reddish; the white space on the side of the neck and scapulars is less extensive, and the rufous of the chest less bright.

The young male closely resembles the adult female.

The Plate represents a male and female in perfect plumage, of the natural size. 




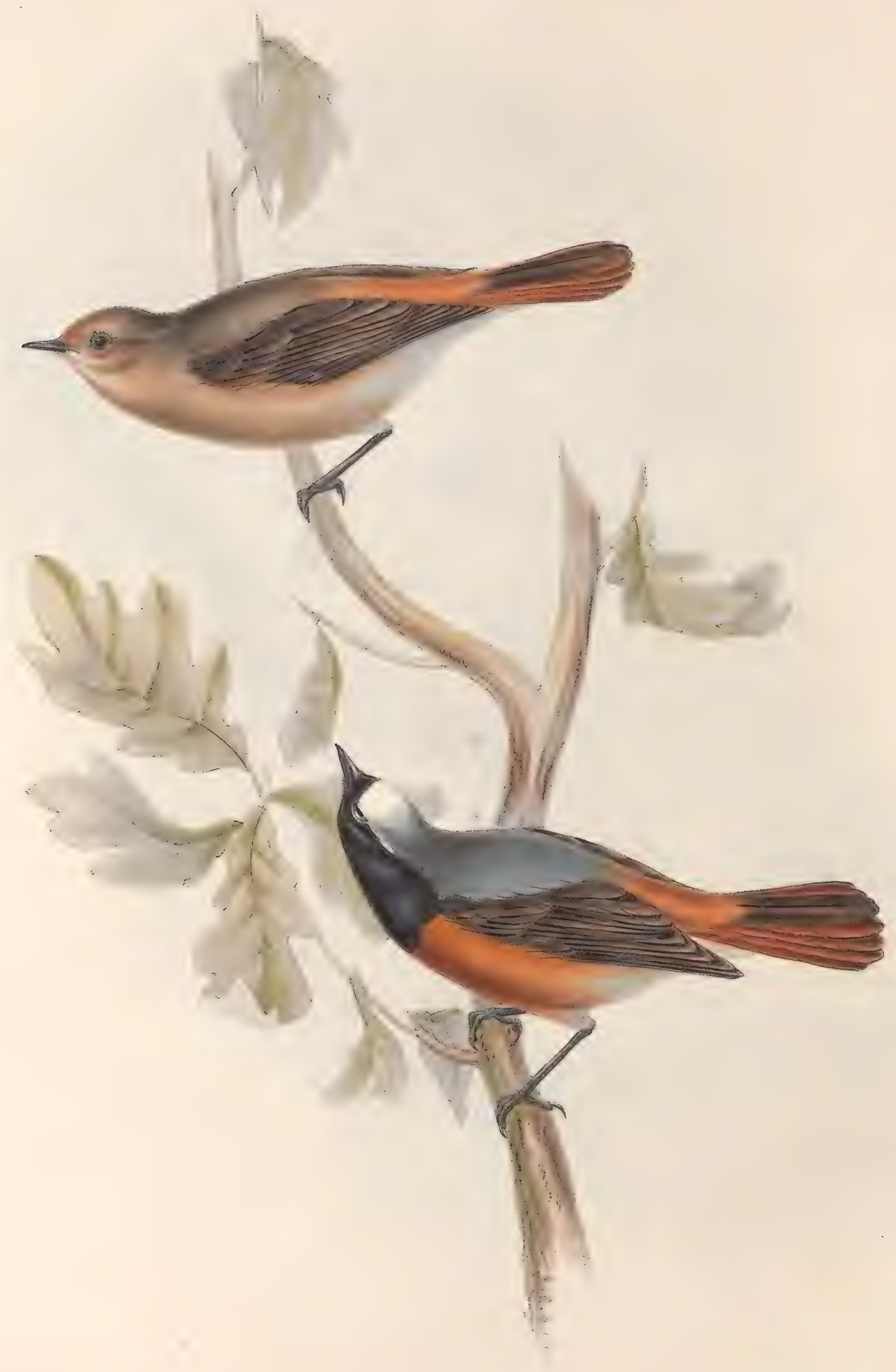

$\mathbb{R} \mathbb{E} \mathbb{D} \mathbb{S}^{\top} \mathbb{A} \mathbb{R}^{\top}$.

Phœricura ruticilla; (Swainss) 


\section{Genus PHOENICURA.}

Gen. Char. Bill rather slender, somewhat widened at the base; compressed towards the tip, which is deflected and emarginated. Tomia of the mandibles, before the nostrils, bending inwards. Gape slightly bearded. Nostrils basal, oval, lateral, pierced in a membrane, and partly concealed by the feathers of the forehead. Wings rather long, with the first quill very short; the second inferior to the third; the fourth the longest of all. Tail of mean length, slightly rounded or square; coloured more or less with reddish brown. Legs having the tarsi longer than the middle toe. Toes slender, the outer toe joined at its base to the middle one; the former and the inner toe short, nearly equal in length and each reaching only to the second joint of the middle one. Clarws not much hooked; that of the hind toe the longest.

\section{REDSTART.}

Phœnicura ruticilla, Swains.

Le Bec-fin de Murailles.

THE genus Phœenicura, as instituted by Mr. Swainson, though the term itself is somewhat exceptionable, forms a well-defined and natural group, of which the present species may be considered a typical example. All the individuals of the genus appear to be confined to the Old World, several of the species being restricted to Asia, and those which may be considered as European being all migratory, and retiring on the approach of winter to a warmer climate.

The Phconicura ruticilla is distinguished by the beautiful contrasts and richness of its colouring, as also by the sprightliness and animation evinced in the vigilant pursuit of its prey, while every action is accompanied by a peculiar vibratory movement of the tail, repeated for a considerable time on its alighting.

Familiar with man, this interesting visiter frequents gardens and orchards, fearlessly building in situations as if expressly to court observation,- - for example, between the branch of a fruit tree and the wall against which it is nailed, the gardener's tool-house, or the holes of an old building or out-house, or, indeed, in any convenient aperture. The eggs are five or six in number, of a beautiful greenish blue colour. During the time of incubation, the male, conspicuous by the band of white on his forehead and the deep red of the tail, may be observed assiduously engaged in the capture of the softer winged insects, which he seizes while flying, darting after them from one resting-place to another with great celerity; he does not, however, return after each sally to the same perch again, like the Flycatchers, but continues a system of irregular pursuit.

As a songster, the Redstart holds no inferior place, though its song is hurried, and the notes neither rich nor powerful; still it never fails to excite feelings of pleasure from its simple sweetness.

The male in the adult plumage has the head and upper part of the back fine blueish ash colour, a broad white band extending from eye to eye across the forehead; the throat black; the breast, rump and lateral tail-feathers of a brilliant rufous; the under surface whitish; the under tail-coverts light rufous ; and the two middle tail-feathers brown.

The female is distinguished by the general greenish brown of her plumage; the upper surface being more tinged with reddish, the throat cinereous merging into reddish brown on the under parts, and the tail dull rufous.

The young birds, like those of the Redbreast, are brown mottled with white : by degrees, however, they lose this plumage, and before leaving us in autumn, the males begin to acquire traces of the distinguishing style of colouring, the head having a tint of grey and the throat showing indications of black, while the upper parts acquire an obscure grey colour, each feather having a reddish margin. At all stages the beak and tarsi are black.

The Plate represents a male and female of the natural size. 




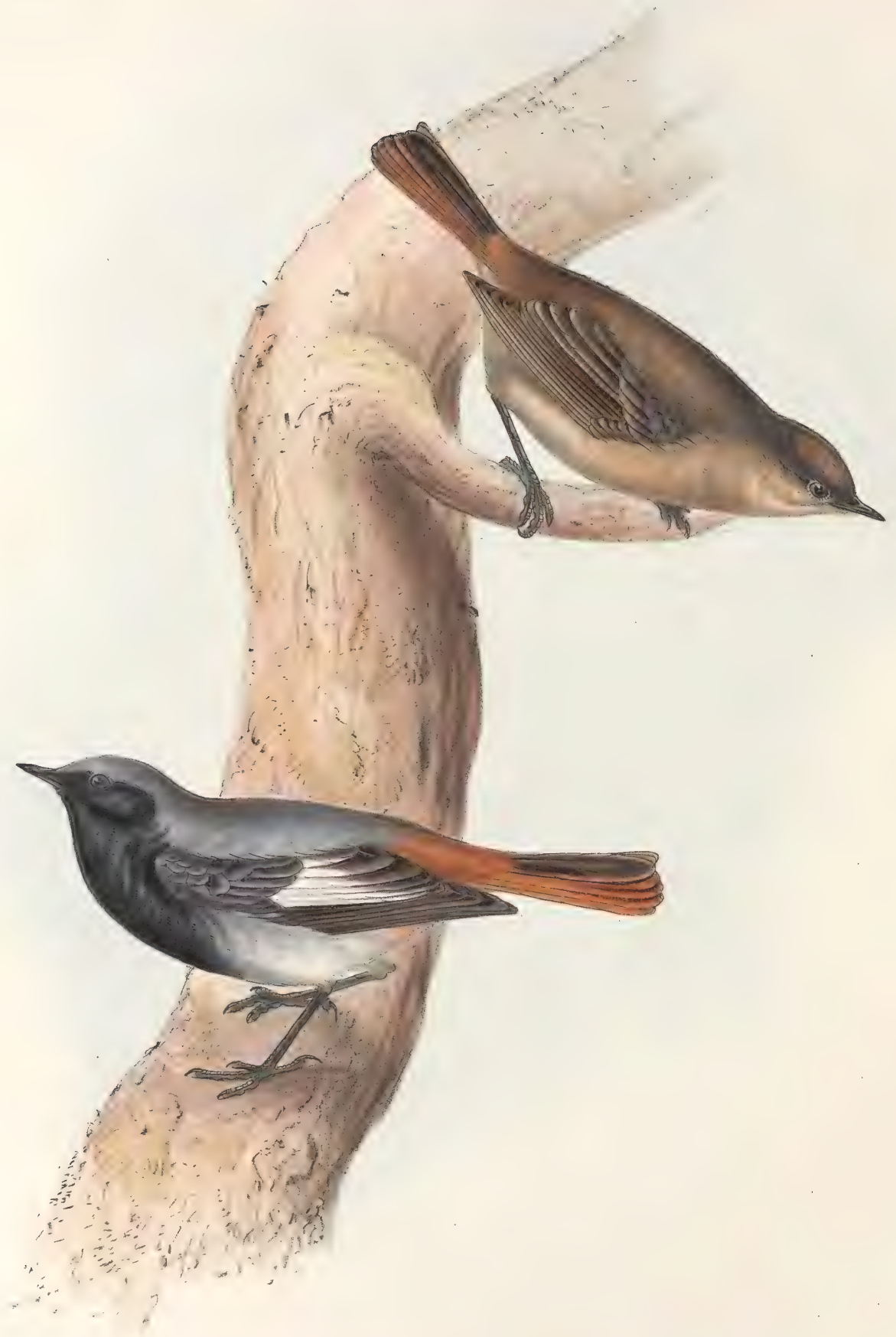

$\mathbb{B} \mathbb{L}_{\Delta} \mathbb{A} \mathbb{C} \mathbb{K} \quad \mathbb{R} \mathbb{E} \mathbb{D} \mathbb{T}_{\mathbb{A}} \mathbb{R} \mathbb{T}$.

Phoericura Tithys; (Iand \& Selby). 


\title{
BLA CK REDSTART。
}

\author{
Phœinicura tithys, Jard. and Selby.
}

Le Bec-fin à rouge queue.

Srnce the discovery of this species as an occasional visitant, as recorded by us in the "Zoological Journal," vol. 5. No. 17. p. 102., we have ascertained the fact of several other examples having been killed in different counties: and here we may mention that a fine specimen was shot at Brighton, another at Bristol, and a male bird was killed on Teignmouth sands in Devonshire, on the 7th of January 1833, by L. Sulivan, Esq., who placed the specimen in our hands. Still the occurrence of the Phøenicura titlys in our island must be considered as a circumstance of extreme rarity, though in some parts of the Continent it is as abundant as its nearly allied congener the Redstart with us. According to $\mathrm{M}$. Temminck, it is found in the northern provinces of Europe, especially in rocky situations, a fact borne out by Mr. Sulivan's observations on the specimen he killed, which was flitting about the rocks on the Devonshire coast. In Holland and the flat lands of the Continent it appears to be nearly as rare as in England. In our late journey through Prussia, we observed it all along the road between Frankfort and Berlin. Its nest, M. Temminck says, is placed in the clefts of rocks, or in the fissures of towers and other old buildings; the eggs being six in number, of a pinky white.

The male and female offer considerable difference in the colouring of their plumage, the former of which may be thus described :-

The space between the beak and the eye, the cheeks, the throat and breast, deep black, which fades off into blueish ash on the belly and flanks; the upper parts are more inclined to dark grey; the forehead inclining to white; the rump and tail bright red, the middle feathers of the latter being brown; the greater coverts of the wings bordered with white; beak, irides and tarsi blackish brown.

The female has the upper parts of a dull brownish grey; the lower parts light grey; the coverts and quillfeathers bordered with grey; the rump and the tail-feathers dull red; beak, irides and tarsi as in the male.

We have figured an adult male and female of the natural size. 




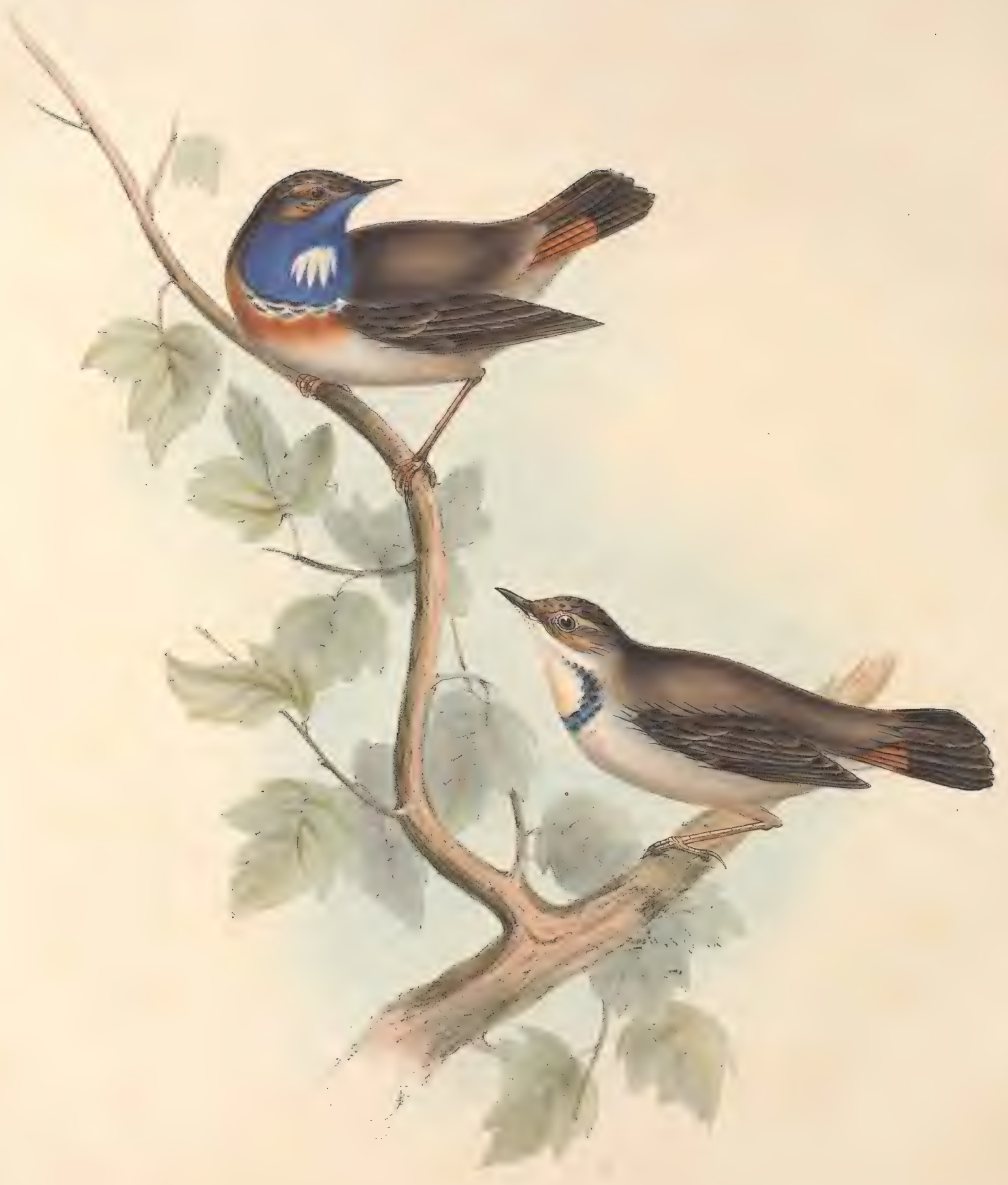

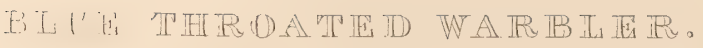

Phoenicura Suecica. 


\title{
BLUE-THROATED WARBLER。
}

\author{
Phœenicura Suecica, Jardine \& Selby.
}

Le Bec-fin gorge bleue.

THE scientific authors of " Illustrations in Ornithology" were induced to separate several species of Warblers from the very extensive genus Sylvia of Latham, on account of their general resemblance to our well-known Redstart. The term Plicenicura was applied to them as a generic distinction, and several reasons have induced us to adopt the genus, and consider the Blue-throated Warbler as belonging to this new subdivision. The species of this small group appear to be intermediate in their nature between those belonging to the genera Saxicola and Curruca. Like the Wheatear, the Blue-throated Warbler is considered a delicate article of food, and in the vicinity of Alsace numbers are captured for the use of the table; in its habits, in the situation often chosen for its nest, and the colour of its eggs, it exhibits a general resemblance to the Redstart.

The Blue-throated Warbler, somewhat resembling our well-known Robin in its form, is found thinly scattered over the countries of Europe, from Sweden to the Mediterranean, but is most plentiful in the central parts of the Continent. Throughout Germany and the Northern territories it is a migratory bird, like many others of the Warblers, appearing in April, and departing in September. On their arrival they frequent thick hedges, small woods and the borders of forests, building their nests in holes of trees, sometimes in cavities between stones near water, or on the banks of rivulets among roots which the action of the stream has laid bare. The nest is formed of dried bents and moss, with a few dead leaves, and lined with various sorts of hair. The female lays five or six eggs of a delicate pale greenish blue; the male is remarkable for his attention to his mate, and has an agreeable song, which is sometimes heard in the night.

The length of an adult bird is nearly six inches; the top of the head, all the upper parts of the body and wings are uniform clove brown; the beak black; over the eye a pale streak; throat and fore-part of the neck ultramarine blue, with a well-defined spot of pure white in the centre; beneath the blue colour is a black bar, then a narrow line of white, and still 'lower a broad band of bright chestnut; belly dirty white, flanks and under tail-coverts light reddish brown; the two middle tail-feathers clove brown, throughout their whole length, all the others on both sides have the basal half bright chestnut, the other half black; legs and claws brown. The female resembles the male in the uniform colour of the upper parts; the white patch on the throat, descending from the beak, occupies a much larger space; the blue colour on the sides of the neck is mixed with black; the successive bars of blue, black, white and chestnut towards the bottom of the neck in front are much less perfectly defined; and the belly and flanks more inclined to brown.

The Blue-throated Warbler is rather a rare bird both in the western parts of France and in Holland, still more rare in this country, only one instance of its occurrence being on record. This specimen was shot in May 1826, by Mr. T. Embleton, on the boundary hedge of the Newcastle Town Moor, and by him presented to the Museum of the Literary and Philosophical Society. The first notice of the capture of this interesting addition to our Fauna appeared in a Synopsis of the Newcastle Museum, by G. T. Fox, Esq., of Durham, (pages 298 and 300 ). This bird was considered a young male, and was probably obtained soon after its arrival.

We have figured a male and female of the natural size. 




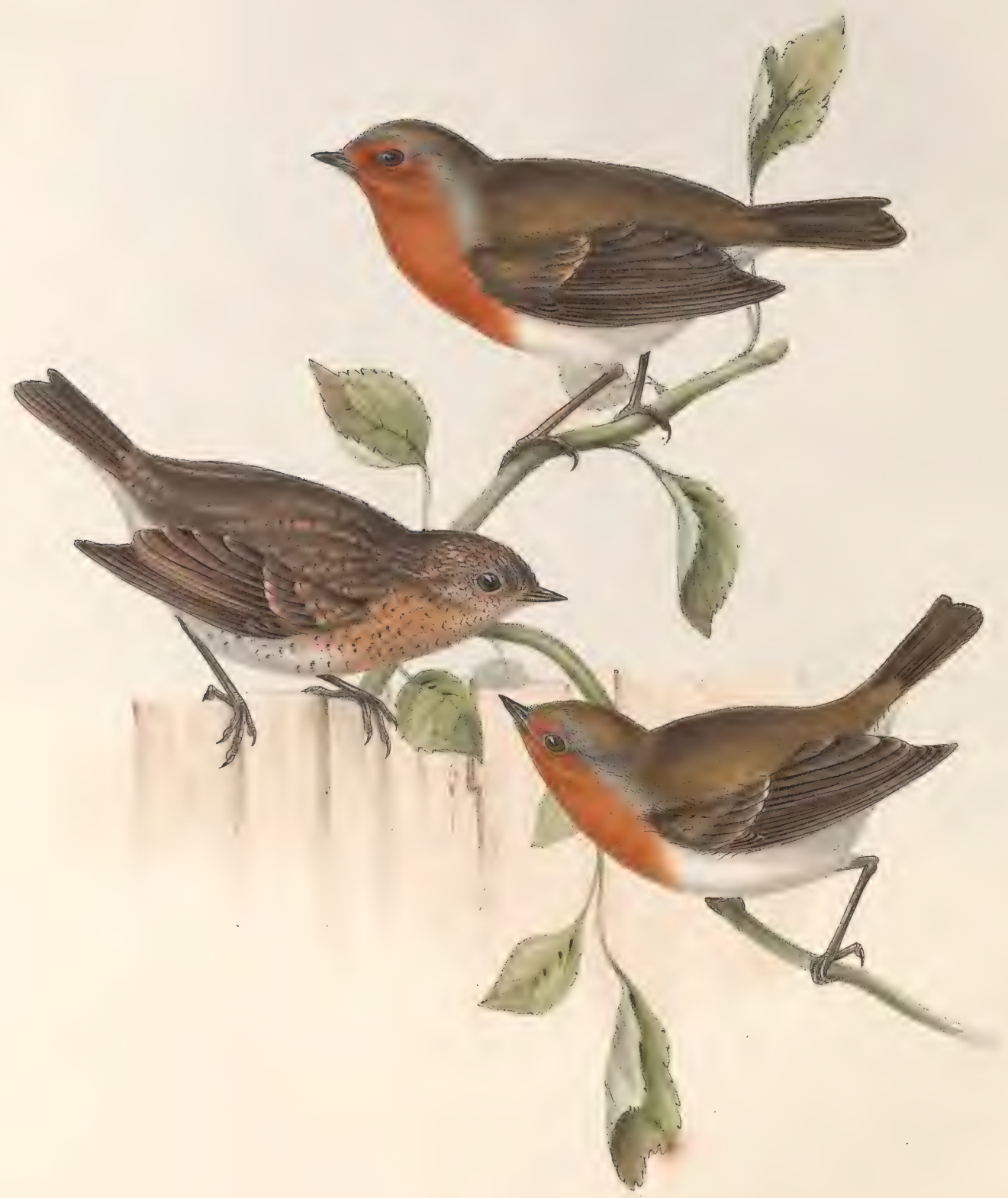

BOBIN 。

Erythaca rubecula; (Swoins:) 


\title{
Genus ERYTHACA, Swains.
}

Gen. Char. Bill broad, rather depressed at the base, gently narrowing towards the tip, where it is slightly compressed; of mean strength, with the upper mandible deflected at the tip, and emarginated. Nostrils basal, lateral, oval, pierced in a large membrane, and nearly concealed by the projecting feathers of the antiæ; gape beset with thick bristly hairs. Wings having the first quill very short, the second double the length of the first, the third shorter than the fourth and fifth, which are nearly equal, and the longest in the wing. Legs with the tarsi longer than the middle toe; the outer toe joined at its base to the middle one; the outer and inner toes short, nearly equal in length, and each only reaching to the second joint of the middle one. Clawes not much hooked; that of the hind toe the longest. Form short and compact.

\section{ROBIN.}

\author{
Erythaca rubecula, Swains. \\ Le Bec-fin rouge-gorge.
}

WE may consider this lively and familiar bird as strictly indigenons to Europe, since among the numerous and extensive collections received from Northern Africa, India, and China we have never observed a single example, neither is it mentioned (as far as we are aware,) by any writer as an inhabitant of those countries; it appears, however, to extend eastward as far as the border line of Asia Minor, one example, and one alone, having been received in a collection from the shores of the Black Sea. In Europe the middle and northern regions are those in which it appears to be most abundant and over which it is universally spread; there are none, indeed, who are not well acquainted with its habits and manners, and with whom it is not a favourite. One of those species whose fearless confidence in man lead it to frequent his gardens and the precincts of his house, its sprightly manners and its animated song, which is poured forth morning and evening even throughout the autumn and colder part of the year when other songsters are silent, render it a most welcome visitor to his habitation. Attractive as the Robin is in all its habits and manners, still it is of a quarrelsome and pugnacious disposition: two males seldom agree to live within the range of the same garden or within a given distance, the stronger always driving away its weaker antagonist; in this respect the Robin differs from many other birds that flock together in winter, and even from its nearly allied species, such as Redstarts and Wheatears, which migrate at the close of summer to a warmer climate, whilst it braves our coldest winters with the utmost impunity. During the greater part of the year its food consists of worms, grubs, the softer caterpillars, and other small insects, together with berries and fruits when in season; but in the depth of winter, when its natural food cannot be procured, it subsists upon crumbs and other refuse.

The sexes, which are alike in plumage, appear to continue mated throughout the whole of the year, and commence the task of incubation at an early period before many of our summer visitors have even arrived, in consequence of which they have generally two broods in the course of the year. The places chosen for the site of the nest is entirely according to circumstances, being sometimes a bank at the root of a tree, at others in the side of a house, in a hole in a wall, in the tool-house of the gardener, \&c. The nest is constructed of moss, leaves, grass, the stalks of plants, or any material near at hand, generally lined with hair; the eggs are five or six in number, of a whitish grey with reddish spots. The young during the first three months of their existence would hardly be recognised as the progeny of the Robin, so much do they differ from the adult birds in the colouring of their plumage; a change of feather takes place in the winter, when their new dress resembles that of the adults and being then fully competent to shift for themselves, they are driven by their parents to a distance and compelled to locate elsewhere.

The top of the head and the whole of the upper surface is of a soft olive brown, the wings and tail being darkest; face, throat, and breast fine ferruginous red; the rest of the under surface dull white; bill, irides, and tarsi blackish brown.

The young when fully fledged have the upper surface of a deep brown, thickly speckled with dots of yellow; the chest is slightly tinged with ferruginous, each feather having a dark brown margin; under surface greyish white.

The Plate represents an adult male and female, and a fully fledged young bird, of the natural size. 




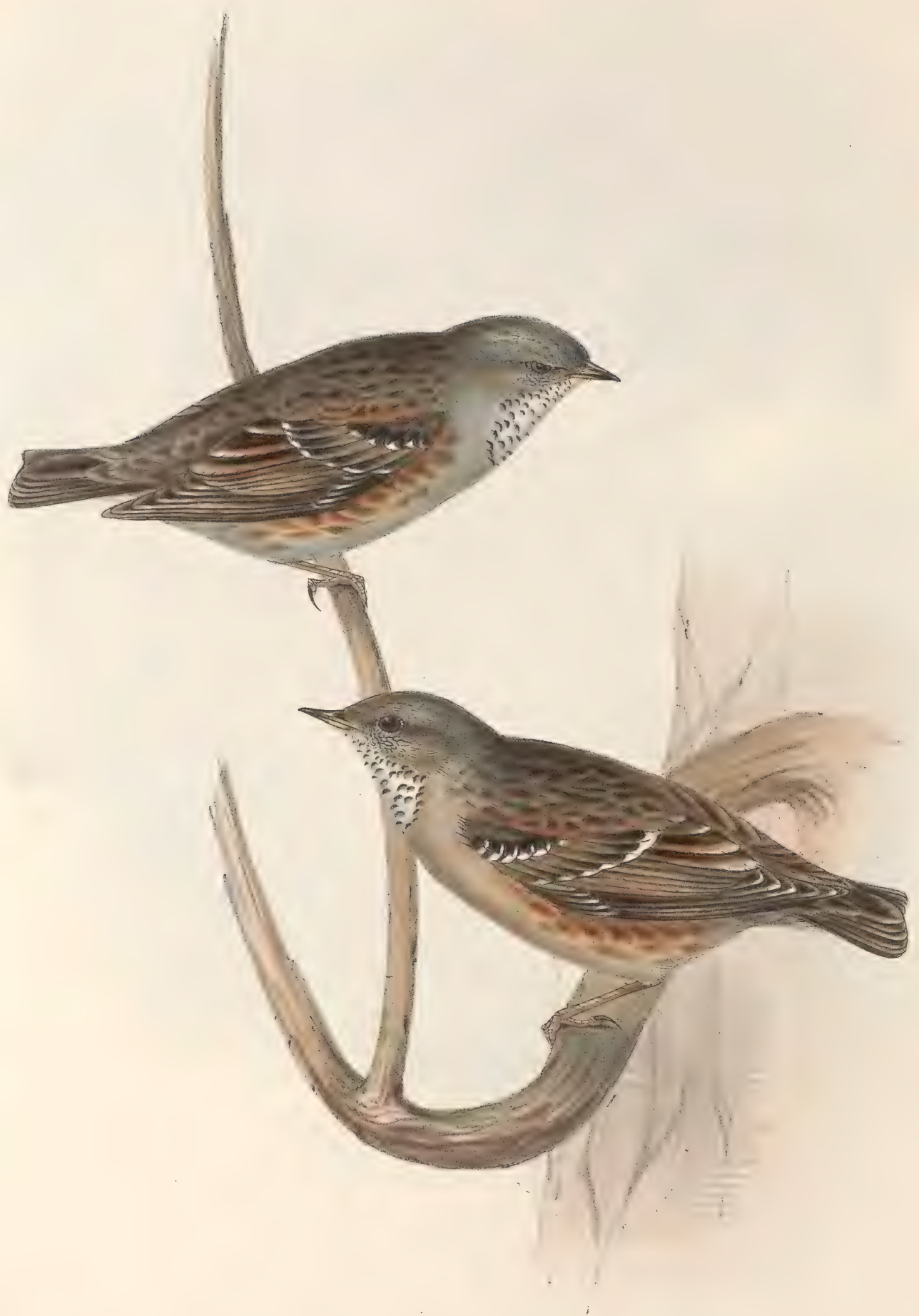

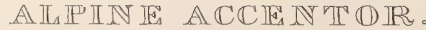

Accentor Alpinus; (Bechst) 


\title{
Genus ACCENTOR, Bechst.
}

Gen. Char. Bill strong, straight, of mean length, and drawn to a fine point; the tomia of both mandibles bending slightly inwards, and the upper mandible emarginated. Nostrils basal, naked, and pierced in a large membrane. Legs strong. Toes three before and one behind; the outer one joined at its base to the middle toe. Wings having the first quill very short, and the second a little shorter than the third, which is the longest.

\section{$A L P I N E$ A C C E N T OR.}

\author{
Accentor alpinus, Bechst. \\ Accenteur pegol ou des Alpes.
}

THE genus Accentor is extremely limited in the number of its species, and, with the exception of an undescribed bird from the Himalayan mountains, the members are confined to Europe.

The native habitat of the Alpine Accentor are the bleak and mountainous parts of the Continent, and, as its name implies, it gives preference to the Alps, where it dwells in districts of the most abrupt and rocky nature. It is extremely common in Switzerland and the Tyrol, ascending in summer to their most elevated portions, and seeking shelter, as winter advances, in their valleys and central regions. Several specimens have been taken in England, and if we recollect right the Rev. Dr. Thackeray, Provost of King's College, Cambridge, informed us that he observed two examples of this singular and rare bird in the garden of King's College ; from the great interest he has always taken in the study of our native birds, two more welcome visitors conld scarcely have come under his notice : one of them, we believe the male, was obtained, and now enriches the extensive and valuable collection of this worthy gentleman.

Its food consists of insects and their larvæ; worms, grubs, \&c. It is also said to destroy grasshoppers and small locusts, which abound in alpine regions.

It breeds in the holes and fissures of the rocks, laying four or five greenish blue eggs, which, though a little larger, are not otherwise unlike those of the common Hedge Accentor of England.

In this well-defined and very natural group, we find the sexes of all the known species to be so strictly similar in the colouring of their plumage as to present no outward difference in their markings; neither do the young offer any material deviation, possessing as they do at an early age the general style of dress, but wanting that brilliancy and decisiveness of marking which characterize the adults.

Our Plate represents a male and female, corresponding in every particular with the bird taken at Cambridge, which, as Mr. Selby informs us, formed the subject of the Plate in his admirable work on the birds of the British Islands.

The crown and upper surface grey brown, the feathers on the back having their centres darker; scapularies and tertials deep brown edged with chestnut brown; greater and lesser wing-coverts black with a white space on the tip; quills blackish brown, with lighter edges; flanks chestnut brown, each feather being edged with greyish white; tail dark brown, each feather having a yellowish white spot on the inner web at the tip; legs light flesh brown; upper mandible dark horn-colour, the under one much lighter.

The figures are of the natural size. 




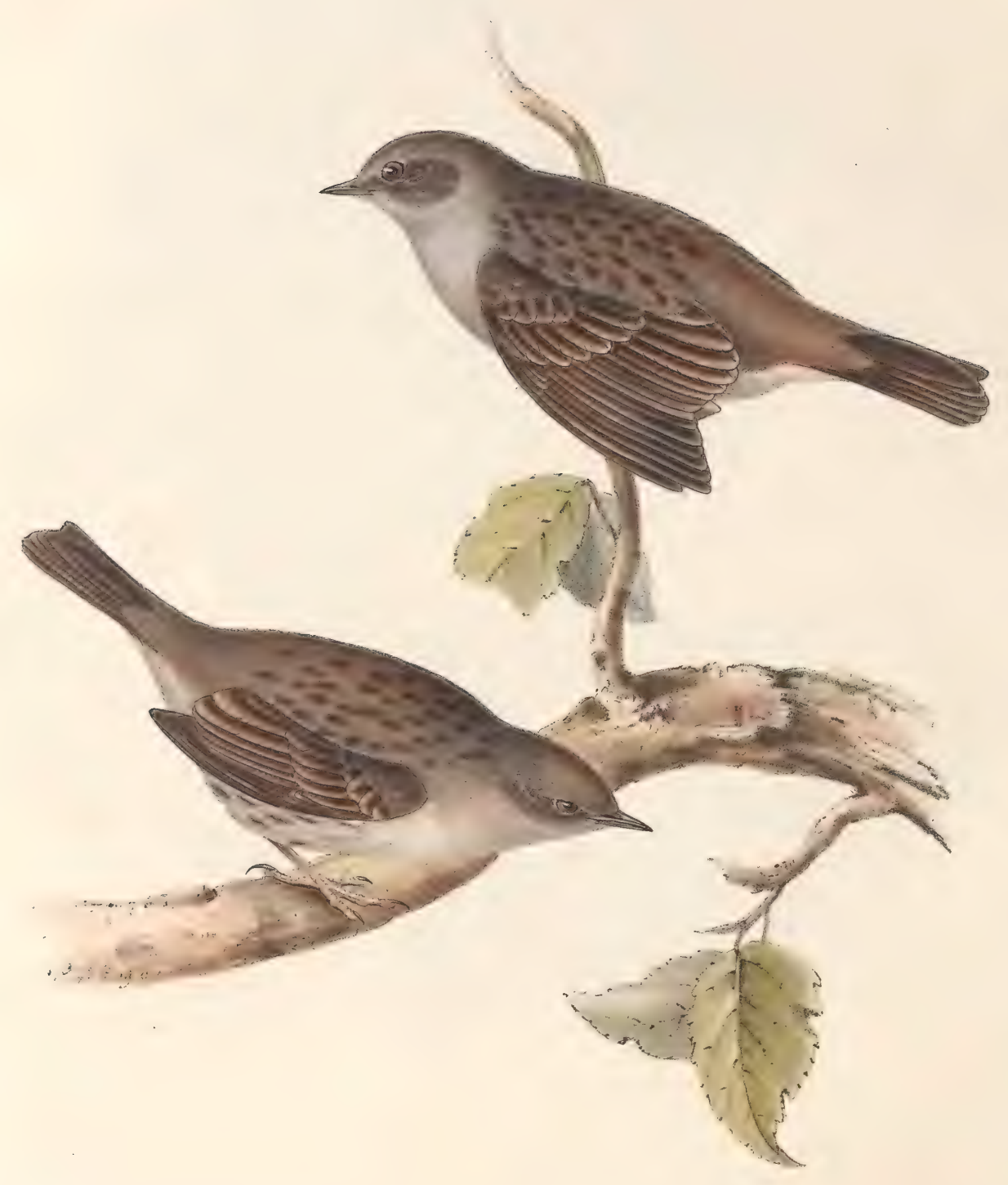

$\mathbb{H} \mathbb{E} \mathbb{D} \mathbb{G} A \mathbb{C} \mathbb{C} \mathbb{E} \mathbb{N} P \mathbb{P} \mathbb{R}$ 。

Accentor modularis; (Cun:) 


\title{
HE D GE A C E N T OR.
}

\author{
Accentor modularis, Cur.
}

L'Accenteur mouchet.

IN every garden and in every hedgerow may this familiar but obscurely coloured bird be seen, not only throughout the whole of Great Britain, but nearly the whole of Central Europe. Though strictly belonging to the Sylviadae, it is one of the few that make our island a permanent place of residence; it is also one of the hardiest of our small birds, and appears to brave the severest winters with indifference. It may be observed when the ground is frozen, and even covered with snow, as lively and alert as at other times in search of its food, which lies concealed on the surface of the earth, or among the dead leaves on banks, bottoms of hedgerows, \&c.; often, indeed, will it mingle with the common Sparrow and the Robin, entering the farmyard, and approaching within the precincts of human habitation, and displaying great confidence and familiarity. Its actions and manners are strictly terrestrial, which is to be accounted for principally from the circumstance of its food, being mostly obtained on the ground: it progresses by a succession of short hops, inquisitively prying among the grass and leaves in search of insects, small worms, the seeds of plants, \&c. During the spring the male pours forth its song, which although not characterized by any great compass of scale, is nevertheless agreeable, and is not entirely suspended during the winter months ; this fact is confirmed by Cuvier, who informs us that it cheers that season with its pleasant song: we also learn from this celebrated naturalist, that although a winter visitant in France, it retires northwards in spring to breed, which is certainly not the case in our own island, as its nest and beautiful blue eggs are well known to every schoolboy. It is an early breeder, frequently beginning to build in the month of March. The nest is usually placed in the thickest part of the hedgerow, and very frequently among furze and evergreens; it is generally composed of moss and wool, intermingled with fine roots and slender bits of twig, with a lining of hair : the eggs are four or five in number, of a beautiful azure blue.

We have never seen this bird in any collection made out of Europe; and, in fact, so exclusively are the species of the genus Accentor confined to this portion of the world, that we have never observed more than a single example of any species in foreign collections; this was a new one from the Himalaya mountains.

The plumage of the sexes is so strictly similar that it is almost impossible, without actual dissection, to distinguish the male from the female; the former, however, has the breast of a more decided grey tint, which feature is also more conspicuous during the spring.

The general colour of the whole upper surface is deep dusky brown, with blotches of a darker colour disposed over the back; earcoverts brown minutely dotted with white; under surface greyish white with a few dashes of brown on the flanks; legs light brown; bill blackish brown

The Plate represents a male and female of the natural size. 




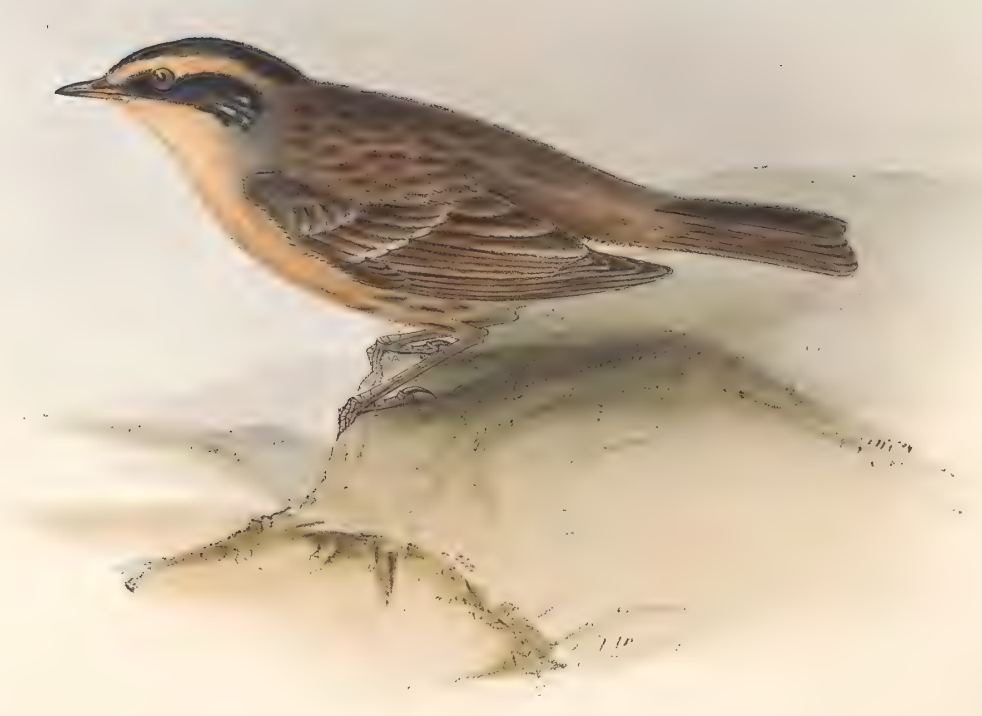

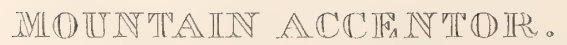

Accentor montanellus; (Cuv) 


\section{MOUNTAINACCENTOR。}

Accentor montanellus, Temm.

L'Accenteur montagnard.

THE most singular circumstance connected with the history of this little bird is, that the specimen from which our figure was taken is the only example we have ever seen, after having visited nearly all the continental collections.

On the authority of M. Temminck we give as its habitat the eastern portions of the middle of Europe, and the same latitudes in Asia. He adds that it was found by Pallas in eastern Siberia and in the Crimea, and that it is somewhat common in the Neapolitan States, in Dalmatia, and in the middle of Hungary.

The specimen above alluded to forms a part of the fine collection of the Imperial Cabinet of Natural History at Vienna, and was killed near the river Krems in Austria, by the late Rev. M. Kratki, curate of Mausling, in the year 1790. Before we had an opportunity of examining this "rara avis," we were inclined to believe it might be a variety of the common species (Accentor modularis), but we are now fully satisfied that our suspicion was groundless, and we can safely add our testimony to its specific value: it is moreover a typical example of the genus, and in affinity closely resembles the common Hedge Sparrow, from which it may be readily distinguished by the conspicuous stripe of buff over the eye, and by the general tawny hue of its under surface.

We cannot close our account of this interesting bird, without expressing our warmest thanks to the Directors of the Imperial Cabinet of Vienna, who, solely for the promotion of science, have encountered the risk of forwarding this valuable specimen from Vienna to London, for the purpose of enabling us to include a figure of it in "The Birds of Europe."

Crown of the head, and a broad stripe commencing at the base of the bill and running towards the back of the head deep brownish black; over each eye a broad and conspicuous stripe of buff; back and scapularies reddish ash with large longitudinal dashes of reddish brown; wings brownish ash bordered with reddish, the tips of the greater and lesser coverts yellowish, forming a double band across the wing; tail brown; all the under surface dull buff, varied on the breast by small dashes of brown, and on the flanks with longitudinal spots of reddish ash; bill yellow at the base and brown at the tip; feet brownish yellow.

Our figure is of the natural size. 




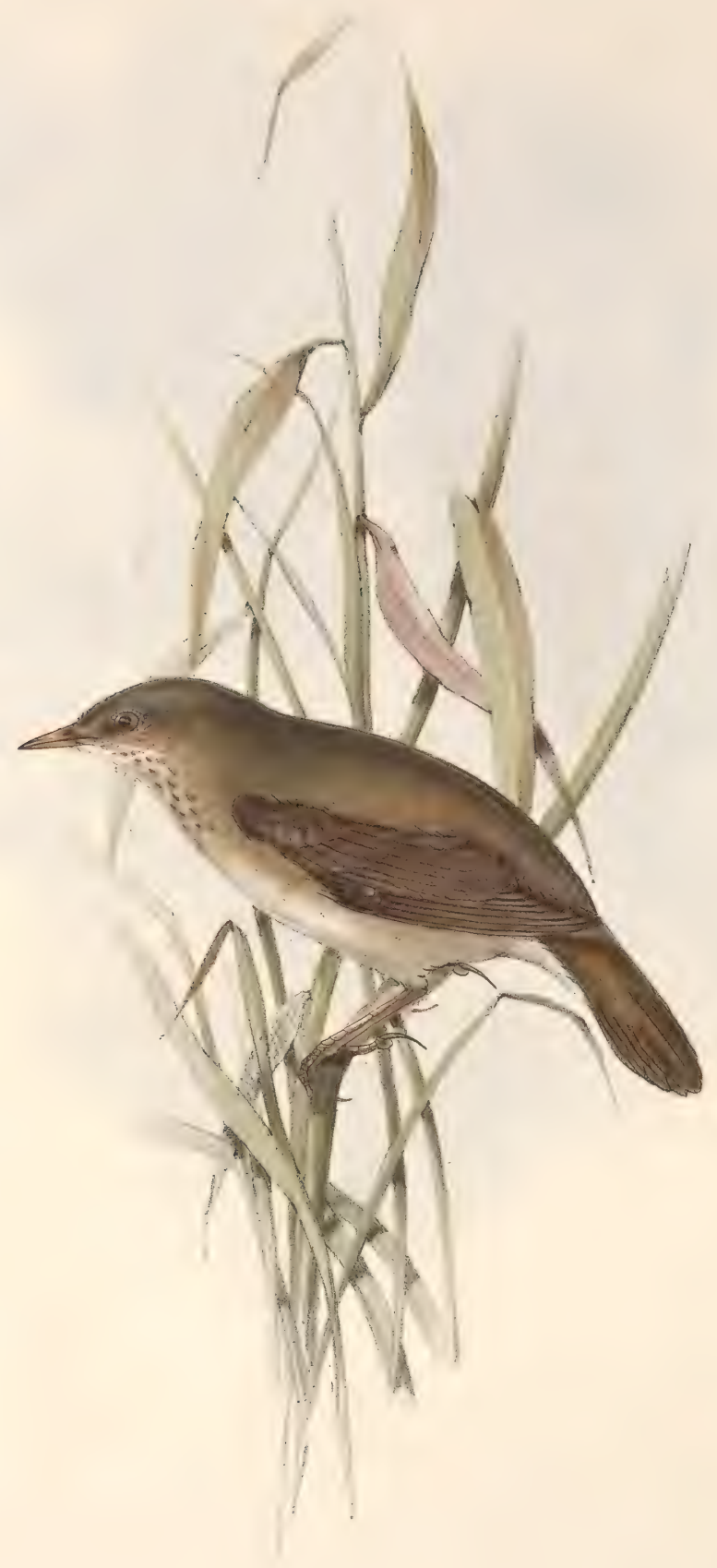




\title{
Genus LOCUSTELLA.
}

Gen. CHar. Those of Salicaria, excepting that the beak is deeper at the base and runs more to a point; rictus bristles rudimentary; the hind claw longer, remarkably slender and clean made; and the tail broader and more decidedly graduated.

\section{REED LOCUSTELLE.}

\author{
Locustella fluviatilis.
}

Le Bec-fin riverain.

Since we learn from M. Natterer that this bird closely assimilates to the Grasshopper Warbler, Lacustella sibilans, in habits, manners, note, particularly in a shrill inward tone producing the effect of ventriloquism, place of resort, food and nidification, and as, conjoined to these affinities, we find that they agree still more closely in structural form, which differs considerably from that of the birds forming the genus Salicaria of Selby, particularly in the lengthened hind claw and in the shape of the beak, we feel no hesitation in assigning to these nearly allied species a distinct generic situation, under the restored title of Locustella. The specific term of fluviatilis as applied to the present bird conveys an erroneous impression, for M. Natterer informs us that although it resorts to low situations, it nevertheless does not confine itself to reed-beds, but rather prefers swampy coppices and thickets. It is extremely scarce in the western portion of the European continent; but is plentiful in Austria and Hungary, and is very common in the island-gardens in the Danube near Vienna.

The sexes exhibit little or no difference of plumage, nor does it appear to undergo any periodical changes.

The upper parts are olive clouded with brown; under surface lighter; the throat and breast whitish spotted with brown; under tail-coverts greyish white; bill and tarsi brown.

We have figured an adult male of the natural size. 




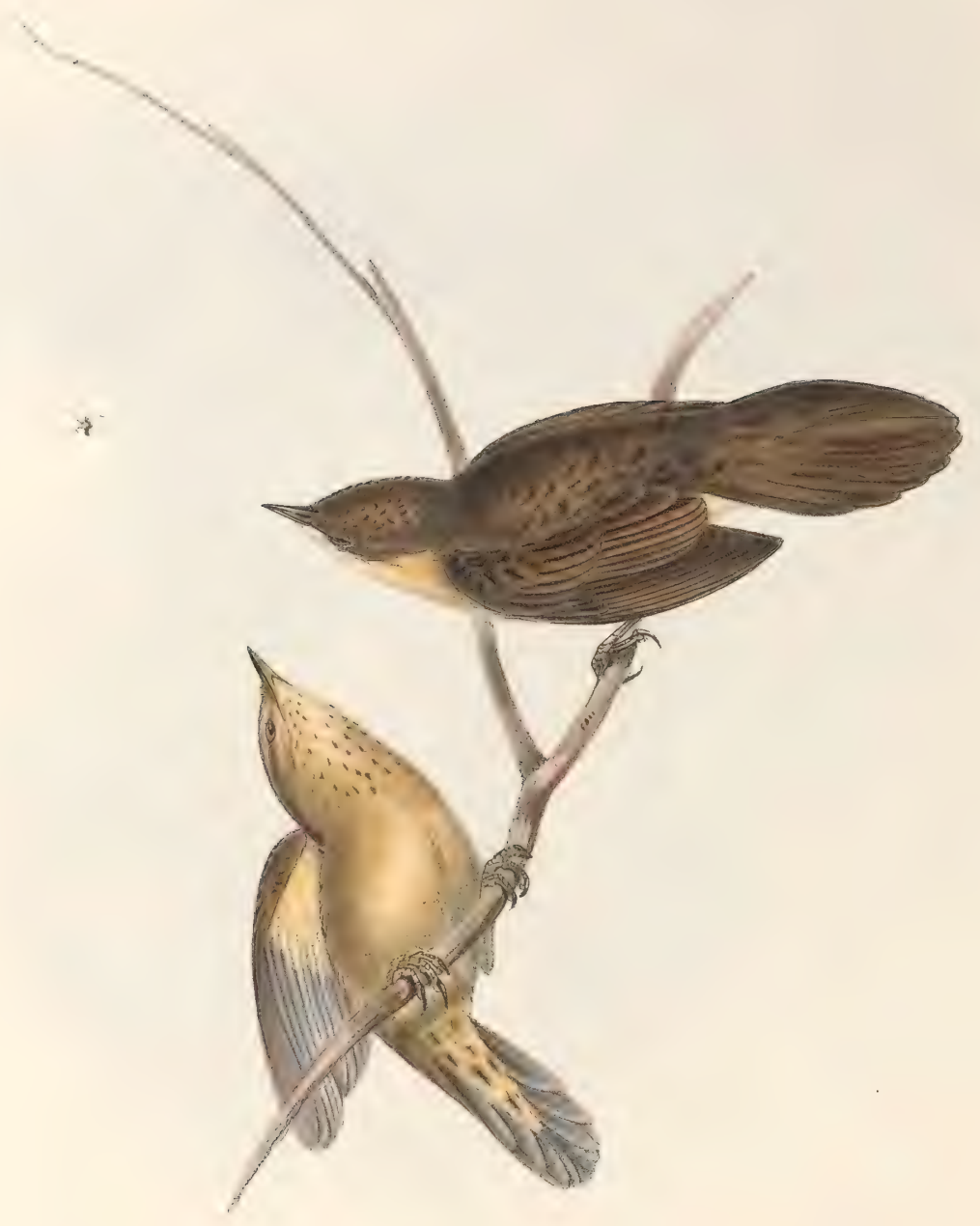

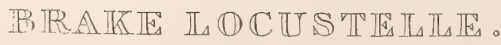

Locustella avicula; (Ray). 


\section{BRA K E I O C S TELIE.}

Locustella avicula, Ray.

La Bec-fin locustelle.

THIs species, to which the modern name of Brake Locustelle has been applied, as more appropriate than those of Grasshopper Lark and Grasshopper Warbler, by which it is known to most of our readers, is one of the migratory birds of our island, where it arrives in the month of April, and although not an uncommon bird, its secluded and shy disposition renders a sight of it extremely difficult, and were it not for its peculiar and sibilant ringing cry, repeated for many minutes and producing a kind of ventriloquism, its presence would seldom be detected. By the term Brake Locustelle our readers are at once informed of the favourite localities to which this species gives preference, in contradistinction to its near ally the Reed Locustelle, whose habits lead it to frequent wet and swampy situations, reed-beds, \&c.

It is pretty generally distributed over our island, but becomes more scarce as we proceed northward. Mr. Selby states that he has known it for some years past as a visitant of several low and damp situations in Northumberland, which would appear to be its limit in that direction : according to Montagu it is also an inhabitant of Ireland.

The nest of the Brake Locustelle is constructed among the densest bramble or furze bushes, and is so secretly placed as to be very seldom found ; it formed of moss and the dried stems of ladies' bedstraw, and greatly resembles that of the Whitethroat, but is thicker and more compact in texture: the eggs, which are four or five in number, are pinkish grey with numerous specks of a deeper tint.

Upper surface brown, tinged with olive; the centre of each of the feathers, except those on the rump, dusky brown; throat white, bounded by a circle of small oval brown spots; breast and flanks pale brown tinged with olive, fading into greenish white on the middle of the belly; under tail-coverts greyish white with black shafts; quills and tail dusky, margined with pale brown tinged with olive; bill brown; legs and feet pale yellowish brown.

The sexes are not distinguishable by their plumage, further than that the male has the spots on the throat more conspicuous.

We have figured a male and female of the natural size. 




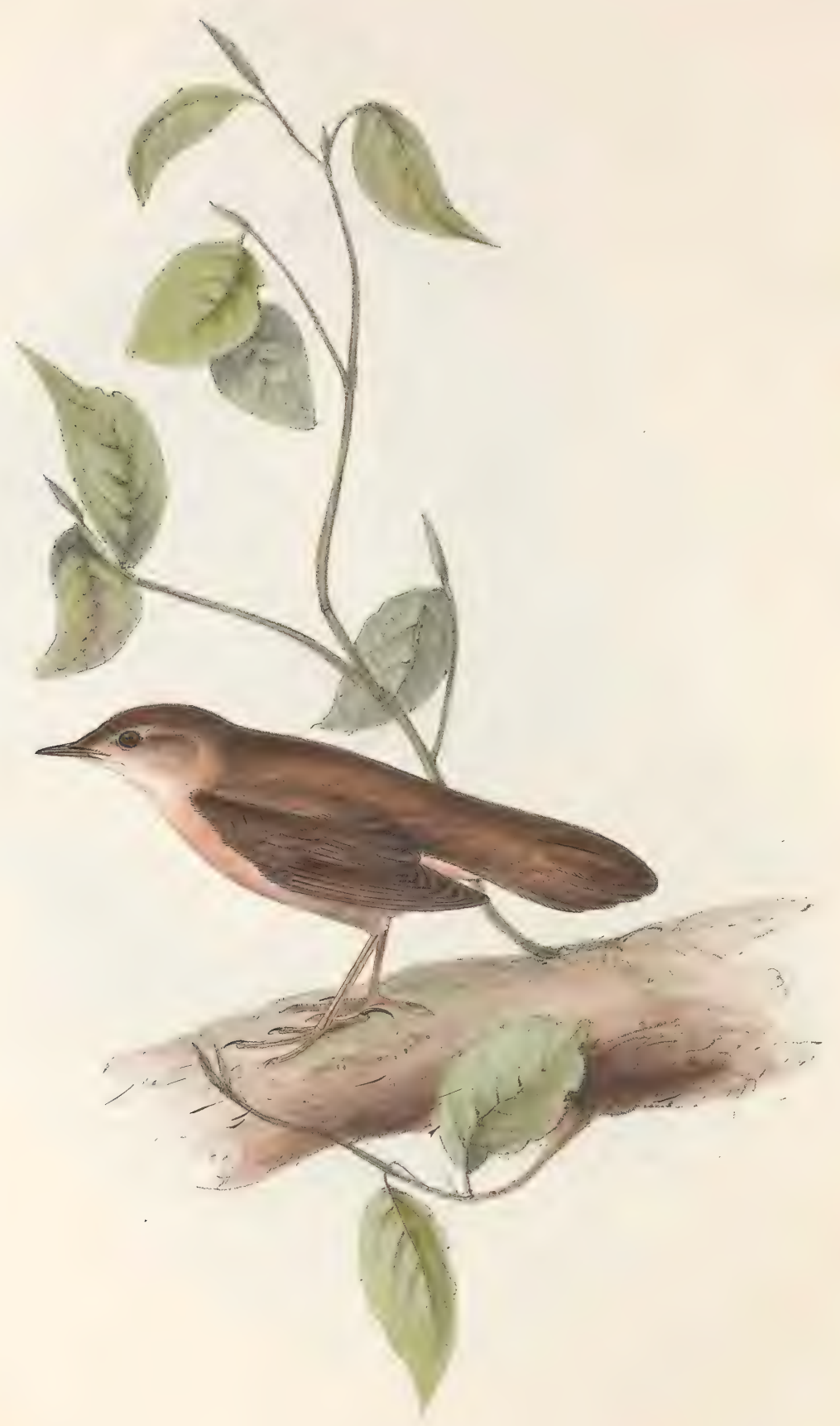

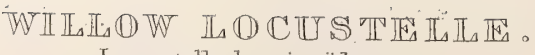

Locustella luscinoïdes.

Sylvia luscinoides; / Savi: 


\section{WILLOW LOCUSTELLE.}

Locustelle luscinoïdes.

Sylvia luscinoïdes, Savi.

Le Bec-fin des saules.

THrs elegant little bird, the Sylvia luscinoïdes of Professor Savi, constitutes the third example, as far as is hitherto known, of the restricted genus Locustella, of which our Grasshopper Warbler is the British representative : it is confined to the southern regions of Europe, where it appears to be very limited in the range of its habitat. According to Professor Savi it arrives in Tuscany about the middle of April, taking refuge among the willows, reeds, and other luxuriant plants of marshy districts, which afford it a secure retreat. It readily admits of approach, may be seen among the lower branches near the ground, and also runs nimbly on the earth among the reeds.

Its food consists of insects and their larvæ.

The Locustella luscinoides is one of the birds lately added to the Fauna of Europe, and we have yet to learn all that respects its nidification and winter retreat, which we may reasonably conclude is Africa.

Head, all the upper surface, and tail reddish brown, the latter almost imperceptibly barred with lines of a darker tint; throat whitish; stripe over the eye, sides of the neck, and all the under surface pale buff; bill dark brown; feet pale brown.

Our figure is taken from a specimen kindly lent to us for the purpose, by the Directors of the Imperial Cabinet at Vienna, and represents the bird of the natural size. 




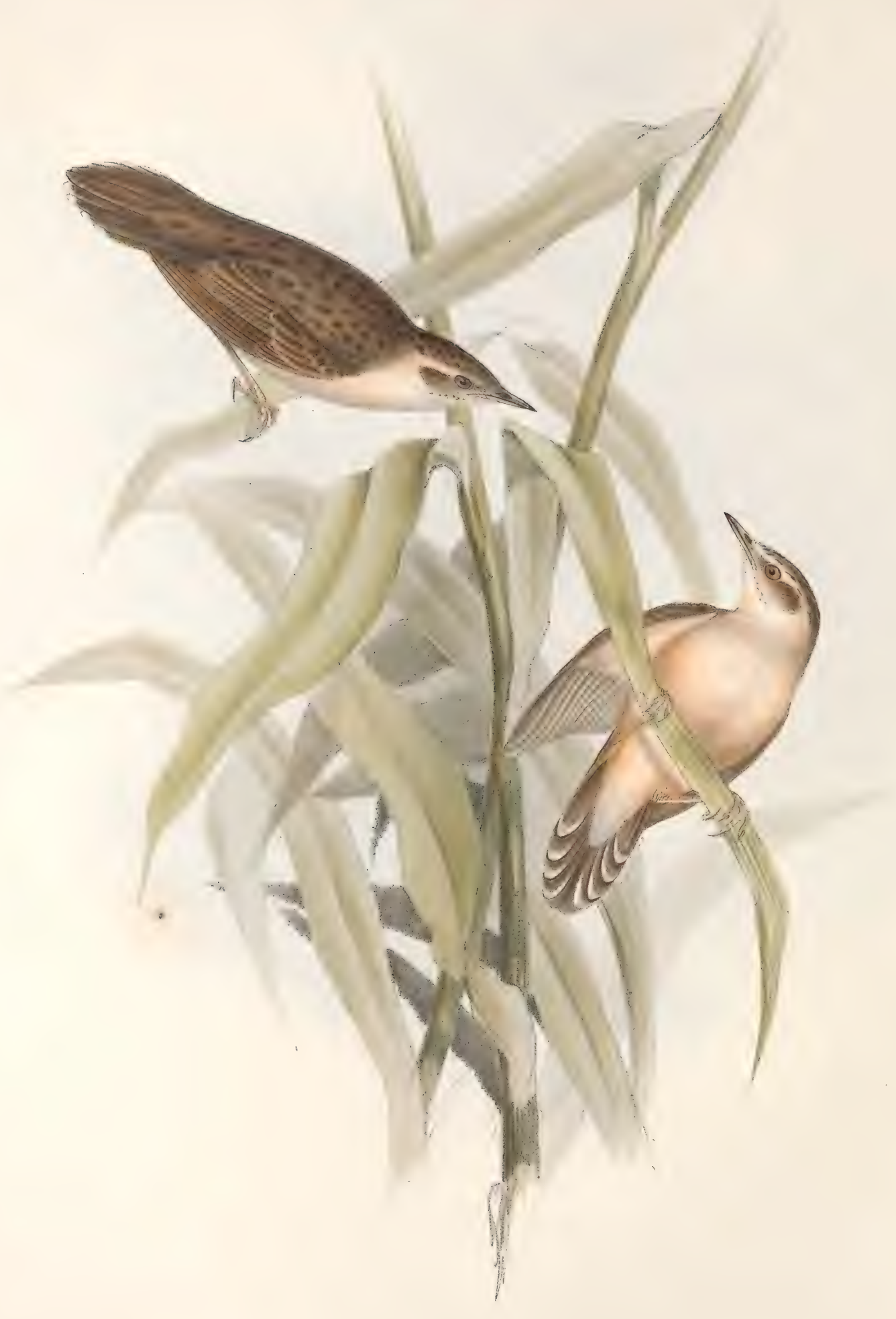

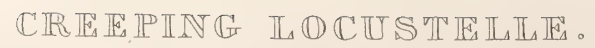

Locustella certhiola. 


\section{CREEPING IOCUSTELIE。}

Locustella certhiola.

Sylvia certhiola, Pall.

Le Bec-fin trapu.

WE beg leave to express our sincere thanks to Professor Lichtenstein, one of the Directors of the Royal Museum of Berlin, for the obliging manner in which he has entrusted to our care the original specimen of this rare bird, from which Pallas took his description, and which we are given to understand was mounted by that celebrated naturalist himself. In form and general colour, and doubtless in its habits, this species strictly belongs to the genus Locustella, from the two other species of which it may be distinguished by its larger size, and by the greyish white termination of all its tail-feathers. Of its habits and manners no account has been recorded, and we only know that it is found in Southern Russia, where it appears to be very scarce. We may here remark, however, that the secluded habits of this race prevent their being observed unless they are very closely watched, and that by the eye of one accustomed to the investigation of the manners of birds in a state of nature.

Feathers on the crown of the head, back of the neck, back and wing-coverts olive brown tinged with red, each feather being dark brown in the centre; primaries and tail reddish brown, the latter tipped with greyish white; throat white; stripe over the eye, sides of the head, and all the under surface buff, which becomes very pale on the breast and centre of the abdomen; bill and feet light brown.

The figure is of the natural size. 





\title{
Genus SALICARIA, Selby.
}

Gen. Char. Bill straight, subulate, expanded at the base, with a distinct culmen, compressed towards the tip, which is slightly deflected and emarginated. Tomia straight, those of the under mandible being gently inflected. Nostrils basal, lateral, oval and exposed. Forehead narrow and depressed. Wings rather short; the first quill nearly abortive; the second just shorter than the third, which is the longest of all. Tail rather long and rounded. Legs having the tarsi longer than the middle toe. Feet rather large and stout; the hind toe large and strong. Clawes moderately curved, long and very sharp, that of the hind toe being double in size and strength to any of the others.

\section{GREAT SEDGE WARBLER.}

\author{
Salicaria turdoïdes, Selby.
}

Le Bec-fin rousserolle.

UNDER the generic title Sylvia, Dr. Latham has included all the soft-billed birds, - an immense multitude, differing in characters and manners. This arrangement, to a certain extent, has been adopted by M. Temminck, with an advance, indeed, towards those subdivisions so imperatively demanded by the laws of nature. The first section is that termed "Riverains," and comprehends a tribe whose habits lead them to frequent the borders of lakes, marshes and rivers, where the reeds and flags afford them an asylum, their food consisting of such insects as abound in these situations. The birds of this section now form the genus Salicaria of Mr. Selby, which we concur in the propriety of thus instituting, as it is at once natural and necessary. Of this genus the present bird may be considered a typical example; for though larger than the other species, yet in form, habits and manners it strictly assimilates with them, frequenting the morasses of Holland in great abundance, as also the low flat lands of France, even in the neighbourhood of Calais, though, strange to say, it does not appear to cross the Channel to England.

The Salicaria turdoïdes is a delightful warbler, whence it has obtained its specific term: its notes are hurried and chattering, like those of the Sedge Warbler, but louder, in accordance with its superior size, and of a richer tone.

Like the rest of the genus, its food consists of gnats, the smaller Libellula, and other aquatic insects. Its nest is situated among the stalks of the growing reeds, like that of our well-known Sedge Warbler. The eggs are five in number, obtuse, greenish white spotted with black and ash colour.

There is no sexual difference of plumage,- - a circumstance which characterizes nearly the whole of the species belonging to this genus.

The upper surface, wings and tail, with the exception of a white stripe over the eye, of a uniform light brown; the under surface white delicately tinged with the same colour; beak brown, darkest along the culmen and at the tip; tarsi light brown.

The Plate represents an adult of the natural size. 




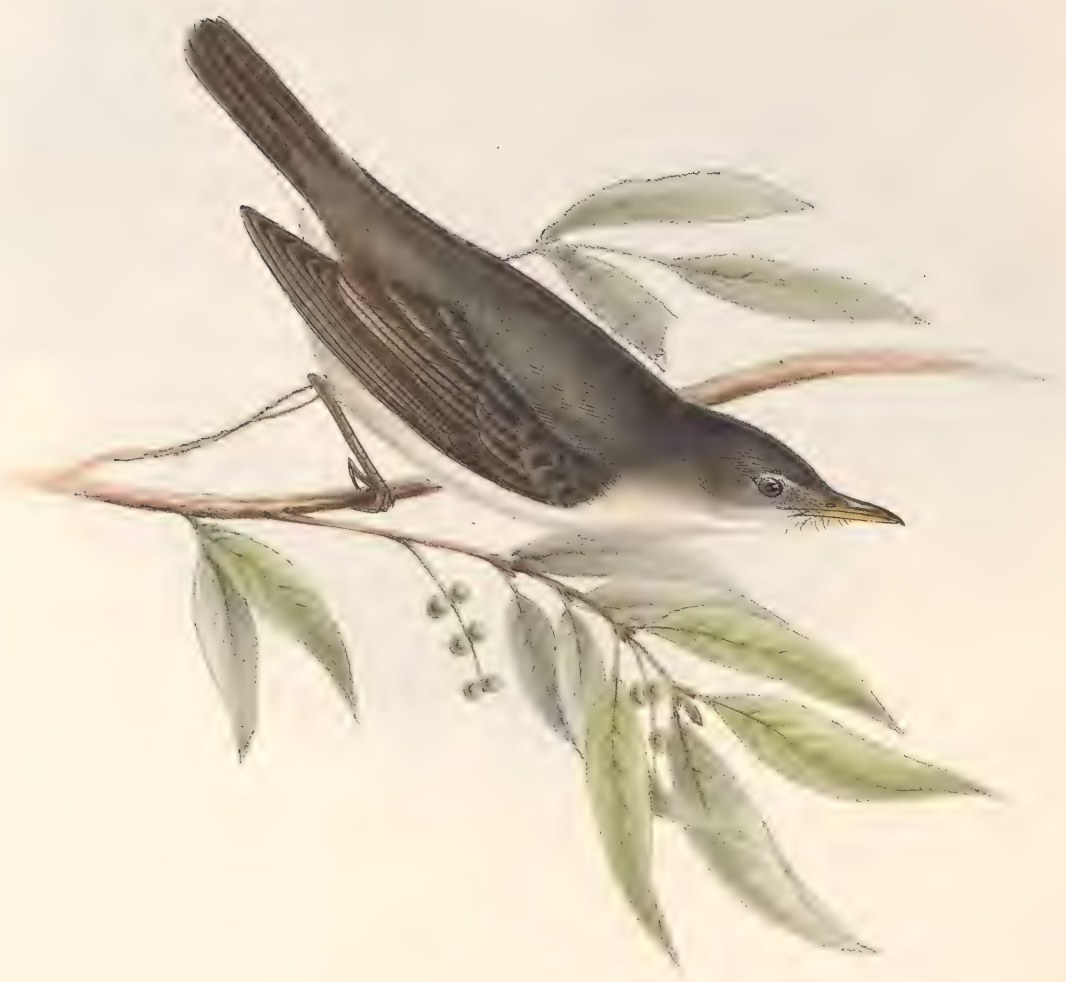

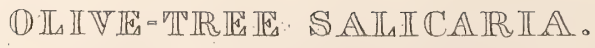

Salicaria Olivetorum: (Strickl.) 


\title{
O L I E E T R E E S L I A R I A.
}

\author{
Salicaria Olivetorum, Strickl.
}

For the knowledge of this new and elegant species of Warbler we are indebted to H. E. Strickland, Esq., by whom it was discovered during the spring of 1836, in Zante, one of the Ionian Islands; and we feel assured that this addition to the European Fauna will be viewed with considerable interest by all lovers of Ornithology, but by. no one more than ourselves, who have for a long time entertained a belief that more new species will yet be found to inhabit the smaller islands of the Mediterranean, particularly those in the Grecian Archipelago.

From its being nearly allied to the Great Sedge Warbler, Mr. Strickland has provisionally placed this bird in the genus Salicaria; but it will, if we mistake not, together with two or three others, be found sufficiently distinct from the smaller members of that genus to warrant their separation under a distinct generic title. We have no recollection of having seen this bird in any collection either from Africa or India; which leads us to believe that the southern parts of Europe constitute its true and native habitat. Mr. Strickland having obliged us with some short notes on this species, we have considered it best to transcribe them here in his own words.

"This bird belongs to that division of the Salicarice in which the tail is but slightly rounded, and the colours sombre and uniform; including the Sylvia arundinacea, Lath.; S. palustris, Bechst.; S. Turdoides, Meyer, and other foreign species.

"I first noticed this bird, in May, 1836, at Zante, where it is by no means rare; but from its shy and restless habits I was only able to procure two specimens, both of which were males. One of these I gave to M. L. Coulon of Neufchatel, and the other is in my collection. It frequents the olive-groves, and is less aquatic in its habits than some of its congeners. Its note is a rambling warble, closely resembling that of S. arundinacea.

"From the proximity of Zante to the Morea, it is probable that this bird exists there also, but it seems hitherto to have escaped the notice of ornithologists.

" The male has the whole upper plumage greyish brown, with a tinge of olive; the space between the bill and the eye lighter; primaries and secondaries dark brown, the latter edged with whitish; tail slightly rounded, and of a dark brown, with the outer feather on each side margined all round, and the two next slightly tipped with white; under surface greyish white becoming darker on the flanks; chest and under tail-coverts tinged with yellow; legs and feet lead colour; beak, orange yellow at the base, darker towards the tip; irides hazel.

Total length 6 inches; wing, $3 \frac{1}{2}$; tail, 3 ; tarsus, $\frac{7}{8}$; bill, from gape to tip, $\frac{5}{8} . "$

Our figure is of the natural size. 




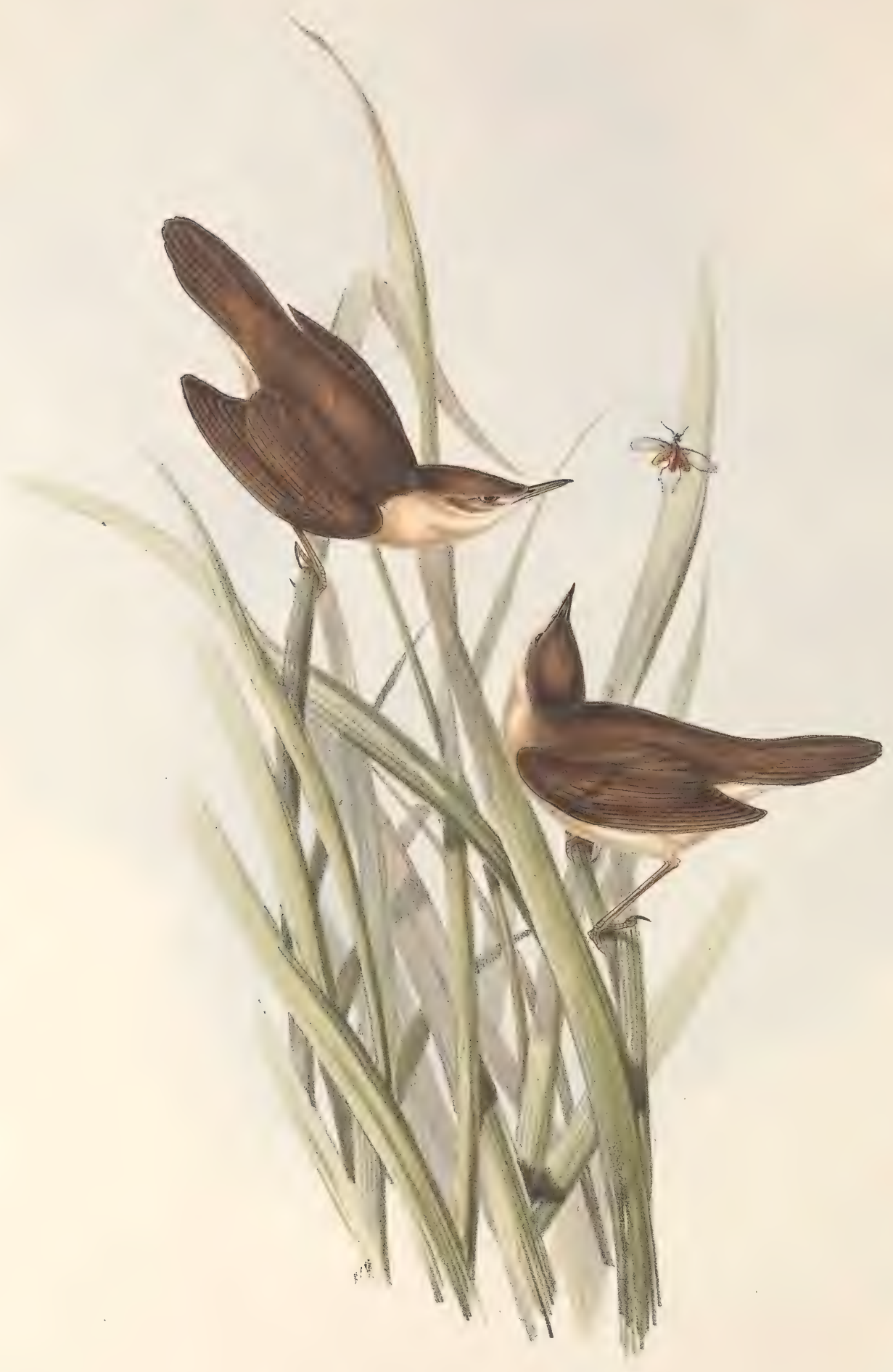

$\mathbb{R} \mathbb{E} \mathbb{E} \mathbb{W} W \mathbb{R} \mathbb{B} \mathbb{I}_{4} \mathbb{E}_{4}^{\mathbb{R}}$ 。

Salicaria arundinacea; (Selb:) 


\section{REE D W R E}

Salicaria arundinacea, Selby.

Le Bec-fin des Roseaux, ou Efarvatte.

THrs species, which is by no means uncommon in the British Islands, is, notwithstanding, much more local in its habits than its near ally the Sedge Warbler (Salicaria phragmitis, Selby), from which it may at all times be distinguished by its larger size, and by the uniform tints which pervade the upper surface. It bears a striking resemblance in most of its habits and manners to the species alluded to above, arriving in the British Islands at the same period, which is generally in the third week in April, when it retires to thick reed-beds, plantations of osiers, and the swampy borders of rivers. Its note, which is varied and pleasing, is not so harsh as that of the Sedge Warbler, but is delivered in the same kind of hurried and rapid manner. It also offers a little difference in its nidification, constructing a deep upright nest of the seed-tops of reeds and long grass, lined with the finer parts of the former, and which is almost invariably attached to the stems of several reeds, which are so intertwined as to form a firm support. The eggs are four or five in number, of a greenish white, spotted and blotched with brown and dull green.

On the Continent it appears to be universally spread in all the temperate latitudes wherever extensive lowlands covered with aquatic herbage afford it a shelter.

Its food consists of aquatic flies and their larvæ.

This species is very abundant in Holland, and is also found in some parts of France and Germany, but is still more rare in the South of Europe.

The whole of the upper surface is of a dull green with a tinge of brown, the edges of the quills being paler; throat, breast, and belly yellowish white, of a deeper tint upon the breast and flanks; between the mouth and the eyes a pale streak; eyelids pale yellowish white; legs dusky brown; bill pale brown.

We have figured a male and female of the natural size. 




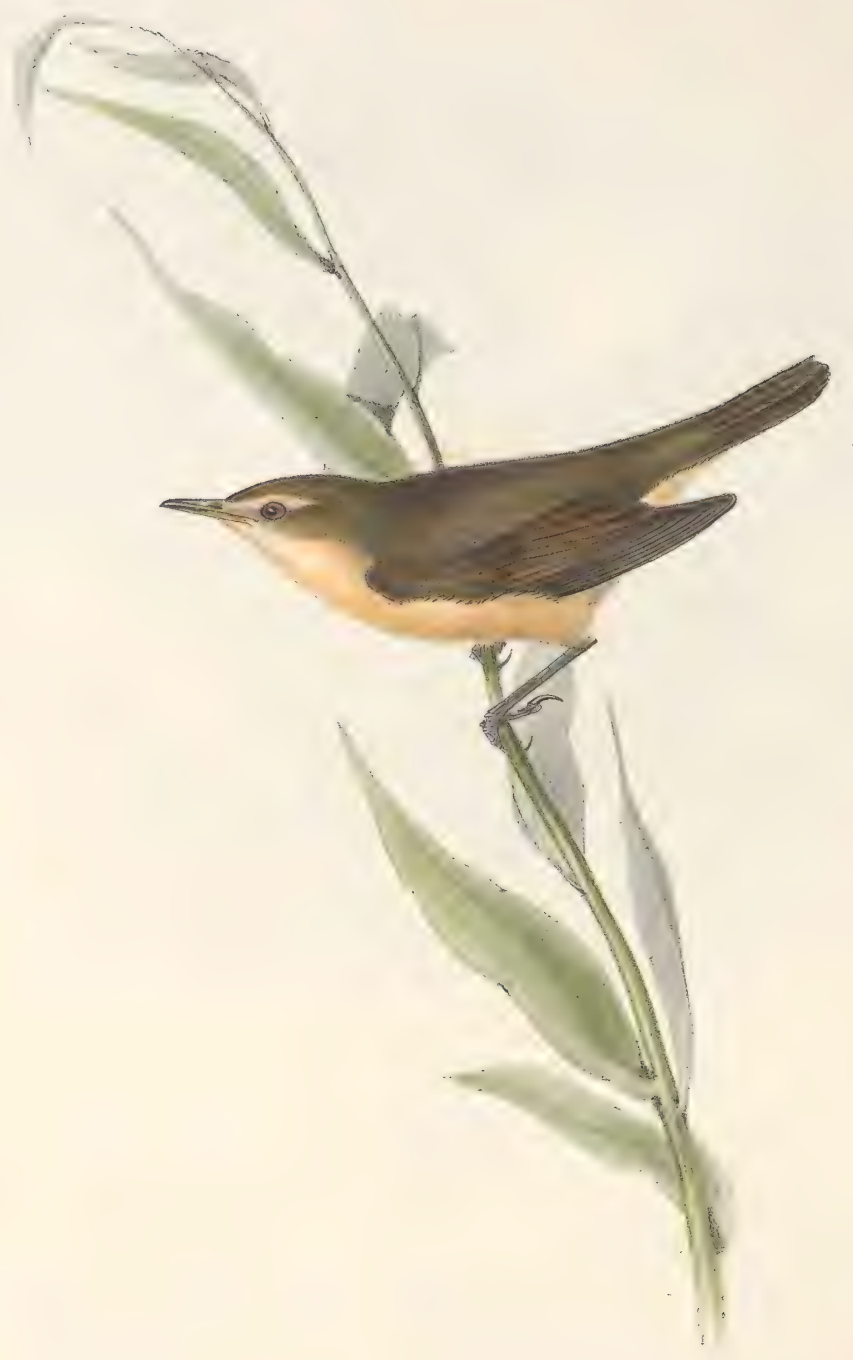

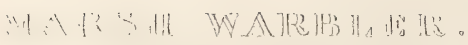

suluarat polustris 


\section{A R S H W A R B L E R。}

Salicaria palustris.

Le Bec-fin verderolle.

IN its general contour this little bird so closely assimilates to the Salicaria hirundinacea, that it would be impossible from the simple examination of preserved specimens to discover that they are specifically distinct: in their habits and manners and in the places to which they resort they are also very similar; but the yellow lining of the mouth, the enlarged size of the bill, and the greener tint of the plumage, are points by which the Marsh Warbler may at all times be distinguished from its near ally. "Another characteristic of this species," says M. Temminck, "is its song, which is singularly varied; it has also considerable powers of mimicry, and readily imitates the song of other birds most completely, particularly that of Sylvia hippolais, as well as the notes of Charadrius minor, and the piercing cry of the Hamatopus ostralegiss."

It generally inhabits humid and marshy situations in the neighbourhood of water, bordered with willows and reed-beds, but is also frequently observed perched upon the high stems of hemp and bushes. It is common in all the middle parts of Europe, and is abundant on the banks of the Po and the Danube, and also in some parts of Switzerland, Germany, and Holland.

The nest is constructed with much art, is of a spherical form, and is placed on the ground among the roots of willows, reeds, and bushes; the eggs are four or five in number, of a clear ash, covered with spots of a bluish ash.

Its food consists of insects and small berries.

Crown of the head, all the upper surface, wing-coverts, secondaries, and tail greenish olive; primaries blackish brown; stripe over the eye, throat, and all the under surface yellowish olive; bill yellow at the base, black at the tip; feet lead colour.

We have figured an adult of the natural size. 




$$
\text { r }
$$




\title{
SED GE W A R B L E R.
}

\author{
Salicaria Phragmitis, Selby. \\ Le Bec-fin Phragmite.
}

THE Sedge Warbler may be distinguished from its near ally the Salicaria arundinacea by the conspicuous stripe which passes over the eye, by its smaller size, and by the less uniform style of colouring which pervades the back and upper surface.

The habits and manners of the two species are so strictly similar as regards the situations they inhabit, and every other particular, that the inexperienced naturalist would be in doubt as to which of them was before him. The bird here figured is by far the most numerous and widely distributed: arriving in the British Islands early in spring, it retires to marshes, banks of rivers, ponds, and lakes, where the luxuriant foliage abounding in such situations affords it a retreat at once secure and in direct unison with its habits. It soon commences the task of nidification by constructing a nest of coarse grasses, intermingled with moss on the outer side, while a lining of finer grasses completes the inner: the eggs are five or six in number, of a pale grey blotched all over with pale brown. The situation of the nest varies considerably, being often placed among the reeds which border the water, while at other times it is situated on the overhanging branches of the willow; and it not unfrequently happens that wet ditches, concealed by thick brambles, afford the Sedge Warbler a secure asylum, in which case the nest is placed in the centre of the thick herbage. In its disposition this bird is restless and noisy : its song is a confused strain, which is poured forth both night and day. It displays great powers of mimickry; among its notes may be distinguished those of the lark, the nightingale, sparrow, and linnet, jumbled together in a hurried babble: its varied song is uttered with greater vehemence when disturbed or irritated. Being somewhat secluded in its habits, it is not so frequently seen as heard. During its residence with us it seldom flies further than from bush to bush, or from one reed-bed to another; yet the power of extended flight has not been withheld from this little warbler, for as soon as its insect food diminishes, and the herbage which has afforded it shelter during the summer undergoes the least decay, the sedge bird is directed by the impulse of nature to seek its subsistence in countries of a warmer latitude, where it may still find an abundant supply.

The Sedge Warbler is found throughout the British Islands, as well as in nearly every portion of the Continent, being especially abundant in France, Germany, and Holland.

The sexes offer no differences in the plumage, and the young assume the adult colouring from the nest.

The top of the head is deep brown; above the eye is situated a distinct yellowish white stripe; back and wings olive brown, the centres of the feathers being darker; rump and upper tail-coverts yellowish brown; throat white; whole of the under surface yellowish white, becoming stronger on the flanks; primaries and tail-feathers brown; bill and legs brown.

The Plate represents a male, of the natural size. 




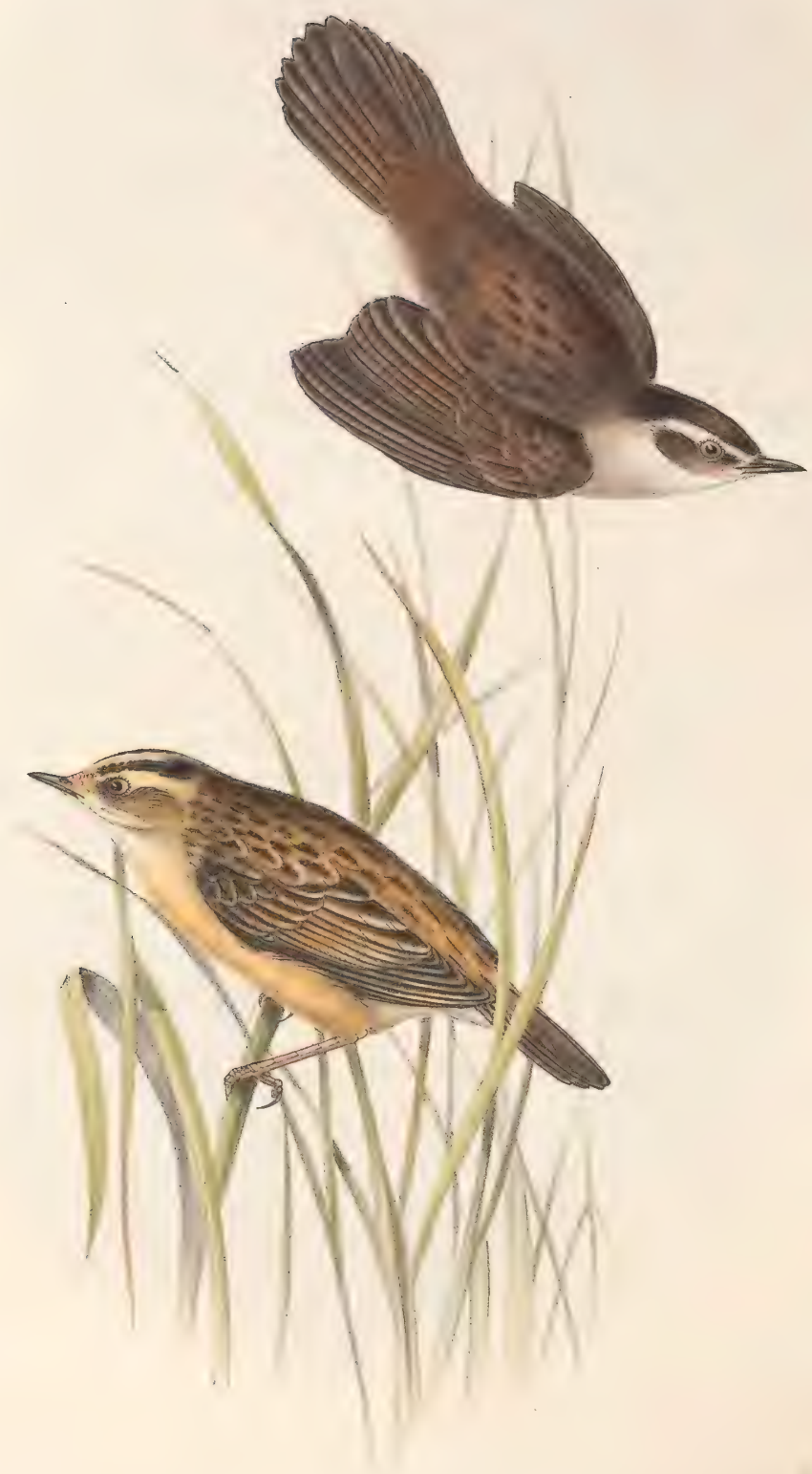

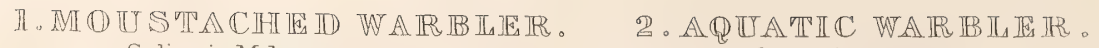




\section{OUSTACHED WARRTRR。}

Salicaria melanopogon.

La Bec-fin à moustaches noires.

This little warbler, now so common in European collections, appears to have been unknown to M. Temminck when he published the second edition of his 'Manuel' in 1820; subsequently, however, he gave a figure of the adult male in the 'Planches Coloriées', 245. fig. 2. and has given a description in the third part of 'his 'Manuel', which appeared in April 1835.

From the little information acquired respecting this bird, it would appear to be principally an inhabitant of the Roman States, where M. Cantraine informs us it is abundant in the marshes among the Arundo speciosa: "I have killed it in November near Rumbla, in the circle of Ragusa, at Ostia, and near the lake of Castiglione, where it is very common; it is always in the marshes, and in the thickets that border them, clinging to the rushes and uttering a very loud cry ; it descends to the surface of the water and walks upon the aquatic plants." From this account of M. Cantraine we gather sufficient information to satisfy us that in its general habits and economy the Moustached Warbler strictly resembles those members of the genus Salicaria that inhabit our island.

Of its nidification nothing is known.

Its food consists of small coleopterous insects.

The sexes offer no perceptible difference in the markings of their plumage.

The top of the head and all the upper surface is of a dark brown, with a slight tinge of reddish brown, particularly on the margins of the wing-feathers, and a black mark down the centre of each of the feathers on the back; a greyish white stripe passes from the bill over the eye and extends to the posterior part of the head, below this is a conspicuous band of dark brown, which passes through the eye and over the ear-coverts; throat and under-surface greyish-white, becoming brown on the flanks and sides of the chest; bill black at the tip and yellow at the base; legs and feet brown; irides yellow.

The upper figure in our Plate represents an adult male of the natural size.

\section{A Q U A T I C W A R B E R.}

Salicaria aquatica.

La Bec-fin aquatique.

ITALY and the eastern portions of the Continent appear to be the true habitat of this species, which, although differing considerably in its markings and colour from the Moustached Warbler, resembles it in many particulars; like that it is also a marsh bird and dwells among the thick reed-beds that border the sides of rivers. It is very abundant in Italy and Piedmont; it sometimes extends its visits to France and Germany, and, but very rarely, to Holland.

The nest is artfully constructed among the stems of aquatic plants, and the eggs are four or five in number, of a yellowish ash colour marked with very fine spots of greyish olive.

The sexes are alike in plumage.

A band of yellowish white passes over each eye and a stripe of the same colour down the centre of the head; the intermediate spaces dark brown; sides of the neck, scapularies, and all the upper surface yellowish brown with large, longitudinal dark brown spots; wings and tail dark brown, each feather in the former strongly edged with yellowish brown; ear-coverts brown; throat and all the under surface of a light fawn colour, which is somewhat darker on the flanks; feet and legs pale brown; bill dark brown at the tip, yellowish at the base.

The lower figure represents this bird of the natural size. 




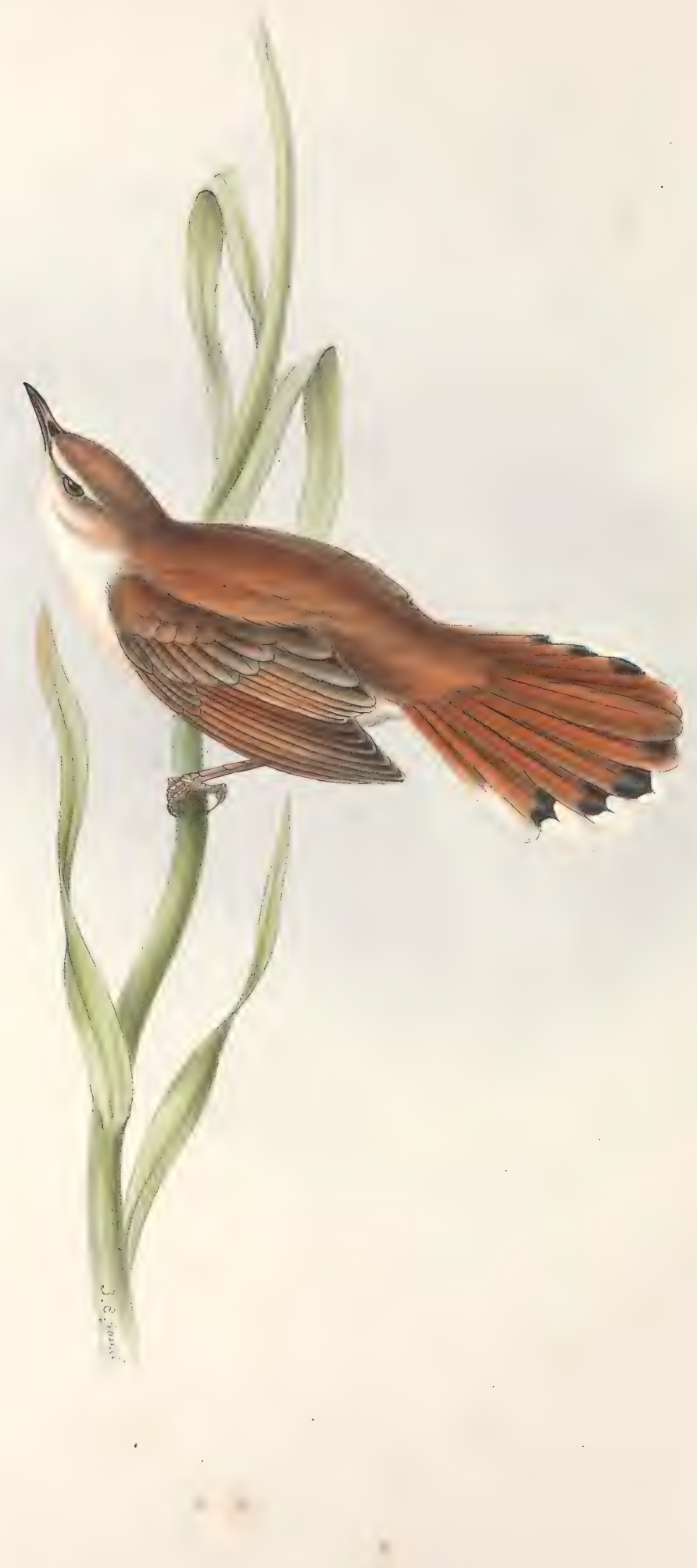

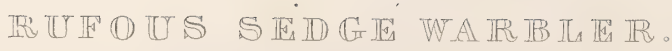
Salicaria galactotes: (Mini) 


\title{
RUFOUS SEDGE WARBLER.
}

\author{
Salicaria galactotes, Mihi.
}

According to M. Temminck, the introduction of this lovely species to the fauna of Europe is due to M. Natterer of Vienna, whose researches have conferred so much honour on himself and benefit to science at large.

Although we possess several fine specimens of this rare species, still, from the want of an intimate knowledge of it, we are yet in doubt as to the true situation it ought to occupy in a scientific arrangement. From a careful examination of the specimens in our possession, in comparison with the birds of M. Temminck's section denominated Bec-fins riverains, which have been formed by Mr. Selby into the genus Salicaria, we are led to assign it to that group; at the same time, we suspect that it may hereafter be found to form an intermediate link between the genus Salicaria and an allied group, the species of which, instead of inhabiting reed-beds and swampy situations, frequent the tall grasses of dry and sandy places, and of which the Sylvia cisticola is an example. On referring to the work of our valued friend M. Temminck, we find him expressing the same doubts respecting this bird which we ourselves entertain ; his words are, "I know not whether this species inhabits reed-beds and the borders of waters: I have therefore arranged it provisionally in this section; for the knowledge alone of its manners and its habits can determine truly the place to which it should be assigned, whether in the section of Riverains or, on the contrary, of Sylvains."

The Rufous Sedge Warbler is a native of the southern provinces of Spain, and probably also of the opposite shores of Africa. M. Natterer discovered it at Gibraltar, and killed two pairs at Algesiras.

The general plumage of the upper surface is lively rufous; the tail-feathers being tipped with white, above which is a larger spot or bar of deep black; the quill-feathers are light brown; a brown band goes from the beak to the eye, and a white superciliary line passes over the eye; the under surface is dull yellowish white, becoming reddish on the flanks; tarsi yellowish ; beak brown ; irides hazel.

We have figured an adult bird of the natural size. 




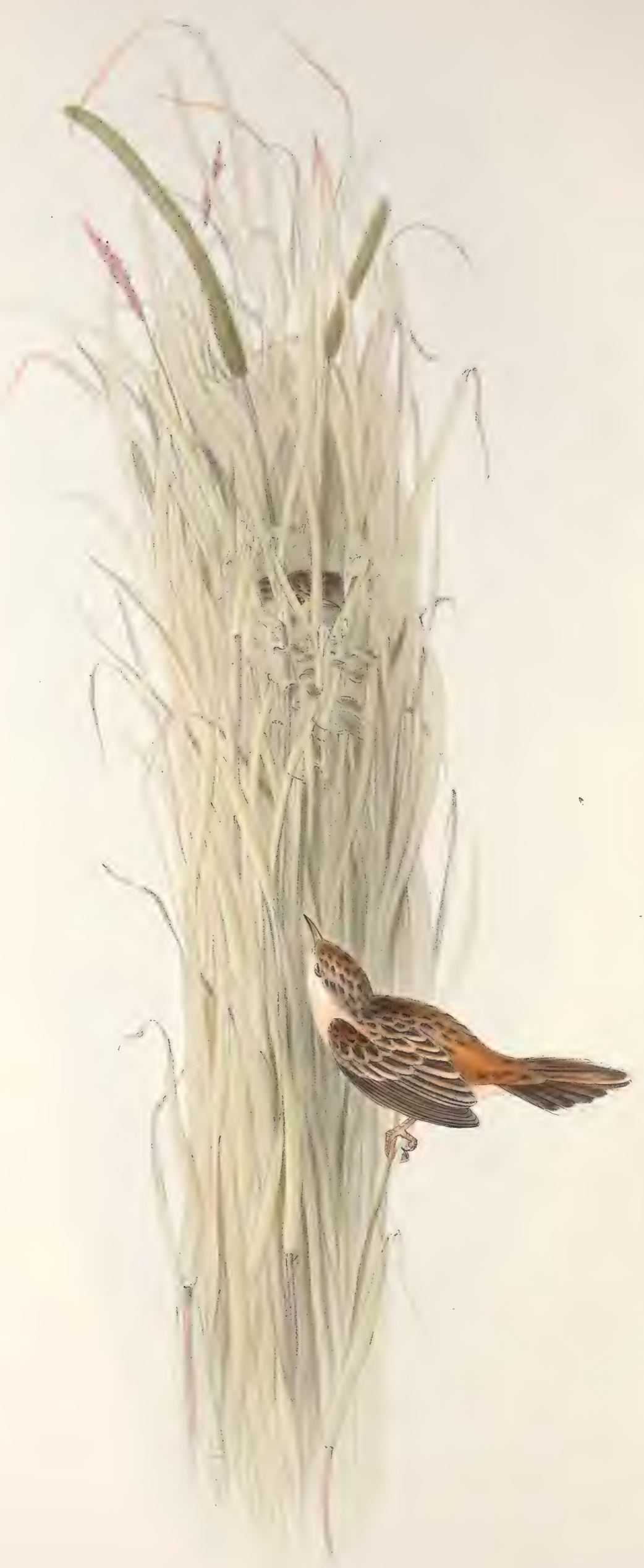

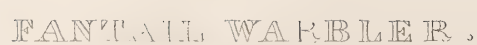

Saliraria Gisticola 


\title{
FA N T A I W W R B LER。
}

\author{
Salicaria cisticola, Mihi.
}

\section{Le Bec-fin cisticole.}

Nот having had personal opportunity of inspecting the habits and manners of this interesting little bird in a state of nature, we are unable to say whether it should form the type of a new genus, or whether it really belongs to that of Salicaria, in which we have provisionally placed it; at all events it cannot be far removed from that genus. It is a species which makes the southern and eastern portions of Europe, together with the adjoining parts of Asia and Africa, its habitat. It is generally distributed along the shores of the Mediterranean from Gibraltar to Constantinople ; is common in the Greek islands and the adjacent mainlands, and is also found in Italy and Sicily. It frequents low and swampy places covered with tall grasses, and, like the Reed Wren, constructs a nest preeminently curious and beautiful, excelled by none of a similar character. Although incapable, from its small size, of entwining the larger reeds, it avails itself of the tall blades and stalks of grass, among which it places its nest; these it does not draw together in the manner of the Reed Wren, but by piercing each blade, and drawing the whole together by means of cottony threads, secured at each perforation with a knot so ingeniously executed as to appear the work of reason. Between the grasses thus secured it places the body of the nest, which is composed of vegetable fibres lined with a kind of flocculent down, collected from various plants. The eggs are four or five in number, and are said to be of a bluish flesh colour. Dr. Latham is our authority for asserting that it is found in the neighbourhood of Gibraltar, everywhere darting about with vast alacrity among the bushes. When disturbed it takes long flights, chirping all the way with a remarkably loud and shrill note, and when in motion it erects the tail and spreads it in a circle, which appears very beautiful; hence the very appropriate name of Fantail.

The male and female are so nearly alike in colour as to require no separate description; the tail of the male, however, is somewhat the more elongated of the two.

The whole of the upper surface is brown, each feather having a dark centre so disposed as to produce a multitude of longitudinal dashes; the whole of the under surface is brownish white; tail graduated, all the outer feathers having a black spot near the extremity; the tip being white; beak and tarsi light brown.

The Plate represents an adult bird in its perfect plumage, together with a nest, of the natural size. 





\section{CETTI WARBLER.}

Salicaria? Cetti.

La Bec-fin bouscarle, ou Cetti.

$W_{E}$ have not been able satisfactorily to determine the true situation of this curious little Warbler: in its general contour and also in its actions, it strongly resembles the species of the genus Troglodytes, or true Wrens, while at the same time it possesses many characters that ally it to the Reedlings, Salicarice, among which we have provisionally placed it. M. Temminck states in his Manuel that it has been killed in England; but on this point we fear that this eminent naturalist must have been misinformed, as we ourselves have never been able to ascertain the existence of any authenticated British-killed specimen. We are inclined to consider this bird as strictly a native of the southern and eastern portions of the European continent and the northern regions of Africa. M. Cantraine informs us that he has found it in the marshes of Ostia, on the borders of the Lake Castiglione, and in the neighbourhood of Rome generally. It is abundant in Sicily, and Professor Savi states that it is a common species in Tuscany, where it breeds, building in large thickets near the ground: the nest is composed of the leaves and stems of dried grasses, and the eggs are of a reddish brown without spots.

The sexes appear to be perfectly similar in the colouring of their plumage, which may be briefly described. All the upper surface of a deep rich brown, passing into blackish brown on the quills and tail-feathers; an obscure line of greyish white over each eye ; throat and under surface greyish white, with a tinge of brown on the flanks; beak and feet brown.

The Plate represents two adults of the natural size. 




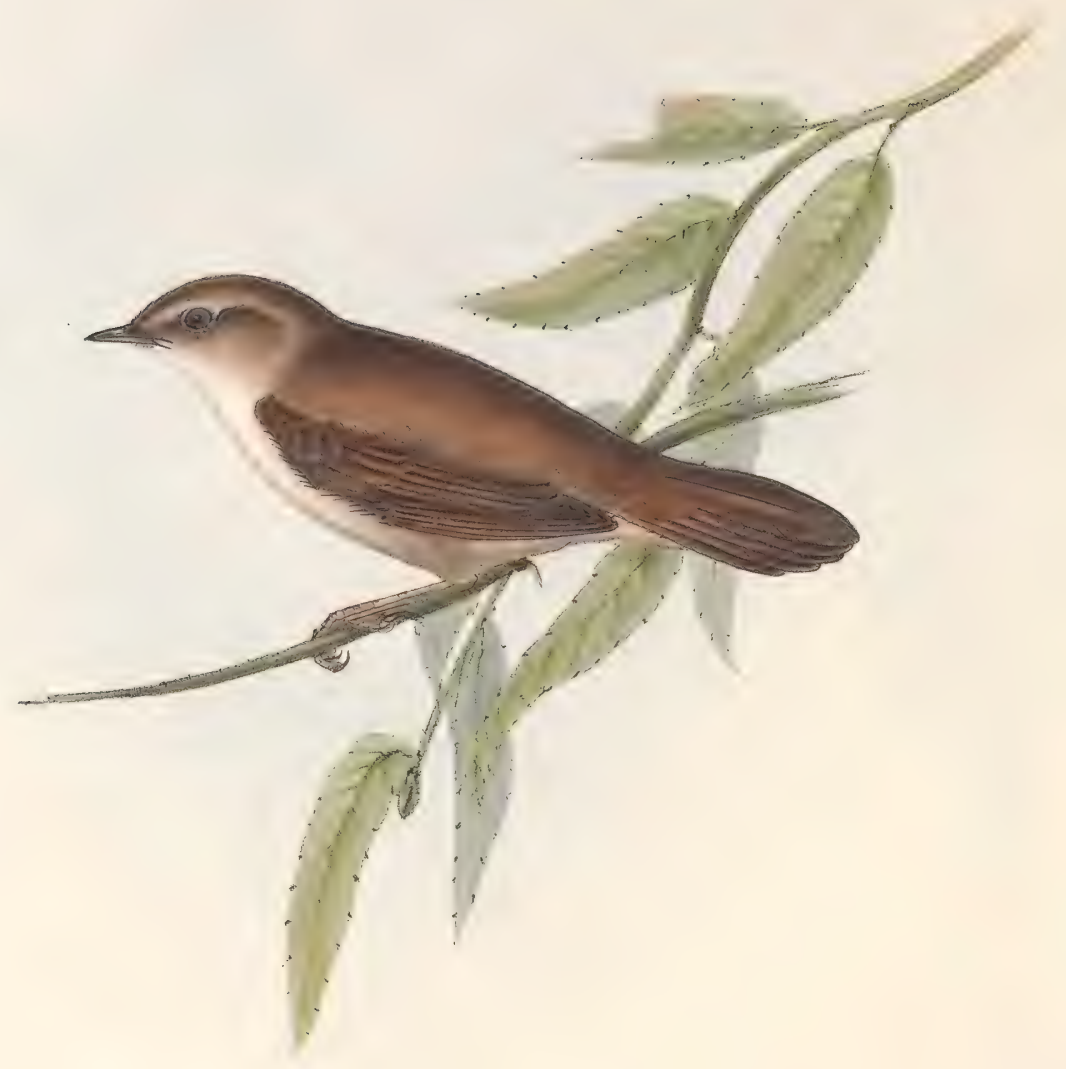

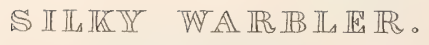

Salicaria? sericea.

Sylvia sericea; ( Nazt:) 


\title{
SILK Y W A R B L ER.
}

\author{
Salicaria? sericea. \\ Sylvia sericea, Natt. \\ Le Bec-fin soyeux.
}

$W_{E}$ have been favoured with the original specimen of this rare bird by our respected friend M. Natterer, who procured it himself on the 17th of April, 1817, "near Santa Anna, upon the river Brenta, two miles from Chioggia, where it inhabits the low bushes bordering the ditches between the vineyards near the Brenta; and has a loud and tolerably fine song."

This bird is very closely allied to the Cetti Warbler, and with that species will, we conceive, constitute a minor division among the "Riverains" of M. Temminck; but as we have already figured the Cetti Warbler under the generic appellation of Salicaria, we refrain from entering into any further details on the subject. The most striking differences which these birds exhibit when compared with the true Salicaria, consist in the total absence of the stiff hairs at the base of the bill; in the more rounded form of the head; in the thicker and more silky plumage, and in the more rounded wing, the primaries of which are soft and yielding. The general contour of the Cetti Warbler, together with its slender bill, immediately reminds us of the true Wrens (Troglodytes); not that we have any reason to believe these groups are joined by affinity, although, particularly in the position in which we have figured it, the Cetti Warbler is remarkably Wren-like, but as we have not seen this bird in a state of nature, we are unable to say anything positive on the subject.

Of its habits, manners, nidification, and eggs nothing is known.

All the upper surface, wings, and tail greyish brown ; stripe over the eye, throat, breast, and centre of the abdomen pure white; sides of the face, flanks, and under tail-coverts brownish ash ; upper mandible dark brown; under mandible and legs flesh colour; irides dark brown.

We have figured an adult male of the natural size. 




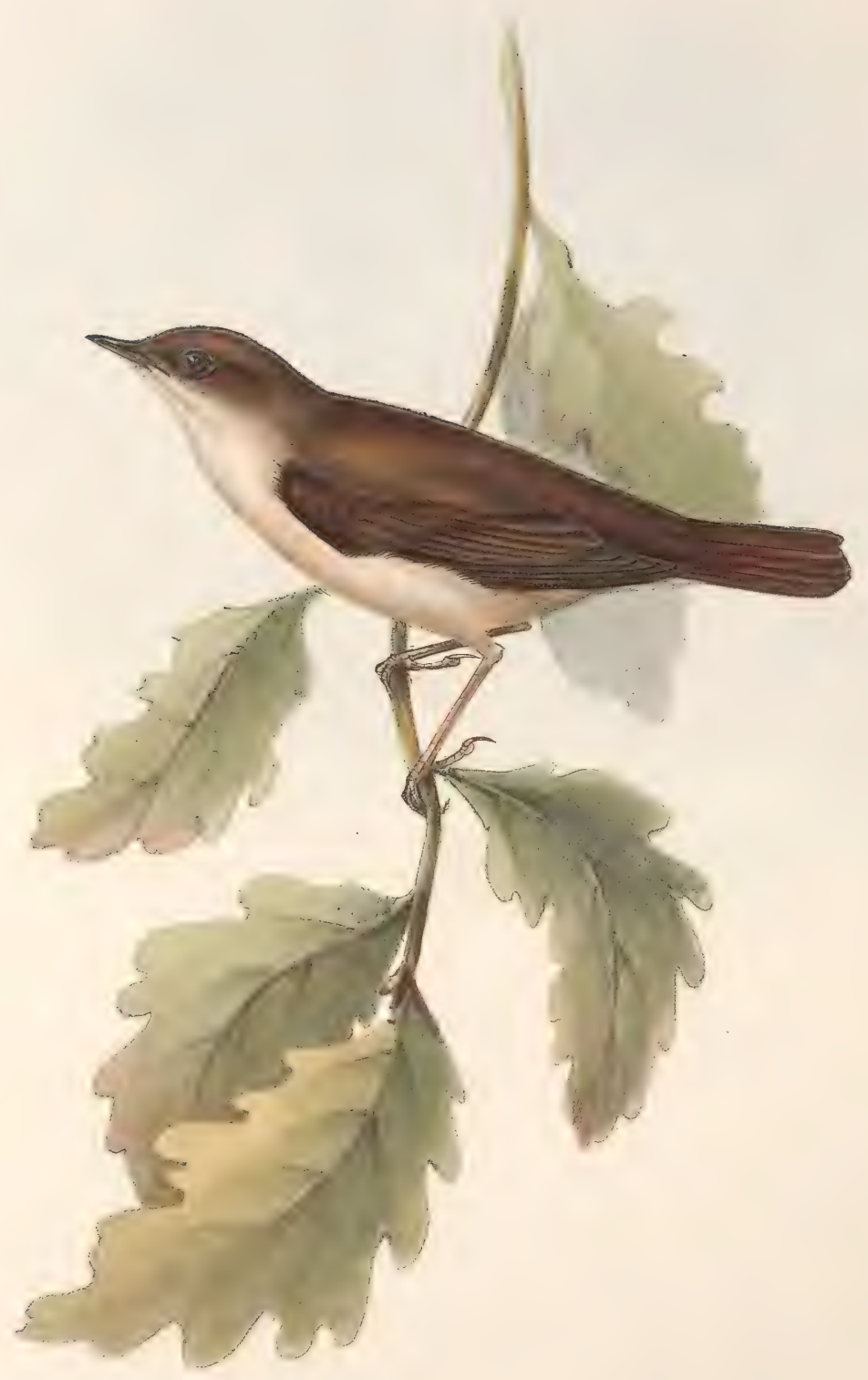

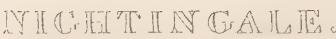

Philomela luscinia; (Sworins:) 


\title{
Genus PHILOMELA, Swains.
}

Gen. Char. Bill of mean length, straight; culmen rounded; tip of the upper mandible slightly deflected and emarginated; lower mandible as strong as the upper; gape smooth. Nostrils basal, lateral, round, pierced in a large membrane. Wings of mean length; first quill very short; second of the same length as the fifth; third and fourth nearly equal and the longest. Tail slightly rounded. Tarsi long. Feet adapted for perching, and also for hopping upon the ground. Clares moderately curved and very sharp.

\section{N I G H T I N G L E.}

\author{
Philomela luscinia, Swains.
}

\section{Le Rossignol.}

IN our notice of this exquisite songster, which has been the theme of poets in every age, we shall confine ourselves rather to details connected with its habits and the localities it prefers in our own island, its migration, \&c., than to the merits of its vocal powers or to indulging in strains of useless admiration.

So much attention has been lately paid by Mr. Blyth to the migration and localities frequented by this species, that we consider it only our duty to refer our readers to that gentleman's paper on the subject published in the 15th and 16th Nos. of the Analyst, which will require but little addition of our own to render the matter clear to every one.

In our island it appears to be confined to particular districts; it is plentiful in the southern and eastern counties, while Devonshire appears to be its limit westward, and Doncaster in Yorkshire in a northern direction, few if any authenticated instances being on record of its occurrence beyond that town, which is the more singular as Nightingales are common in Sweden and other countries situated further north than England.

Our own observation respecting the migrations of the Nightingale is, that after leaving our island it proceeds to the opposite shores of the Continent, and gradually makes its way southwards until it arrives in Africa, which is its ultimate resting-place during our winter months. We have ourselves received specimens killed in the northern districts of Africa, but have never obtained any from the central or southern parts of that portion of the globe; it would appear therefore that its distribution over that vast continent is comparatively limited. In no part of Europe is it more abundant than in Spain and Italy; from whence however, equally as from our own, it regularly migrates on the approach of winter.

The Nightingale is exceedingly shy in its habits; and inhabiting low and swampy coppices, close thickets, hedges, and similar situations, it. is seldom seen, its retreat being only discovered by means of its peculiar call-note and its song, which for richness and power is unrivalled until he is mated, but as soon as this takes place his notes are only poured forth at intervals and entirely cease previous to migration, when the sexes separate, and the males precede the females by ten days or a fortnight.

The nest is placed on the ground or on a low stump, and is constructed of withered leaves, sometimes lined with dry grass : the eggs, which are of a plain yellowish brown, are from four to six in number. The young appear to be principally fed with small green caterpillars, "in all probability the larvæ of some moth, or perhaps of a T'enthredo, peculiar to some localities."

The food of the adult consists of insects and their larvæ, berries, and fruit.

The sexes are alike in plumage, and may be thus described :

All the upper surface deep rich brown; rump and tail reddish brown; throat and middle of the belly greyish white; sides of the neck, breast, and flanks grey; bill and legs light brown.

We have figured an adult male of the natural size. 




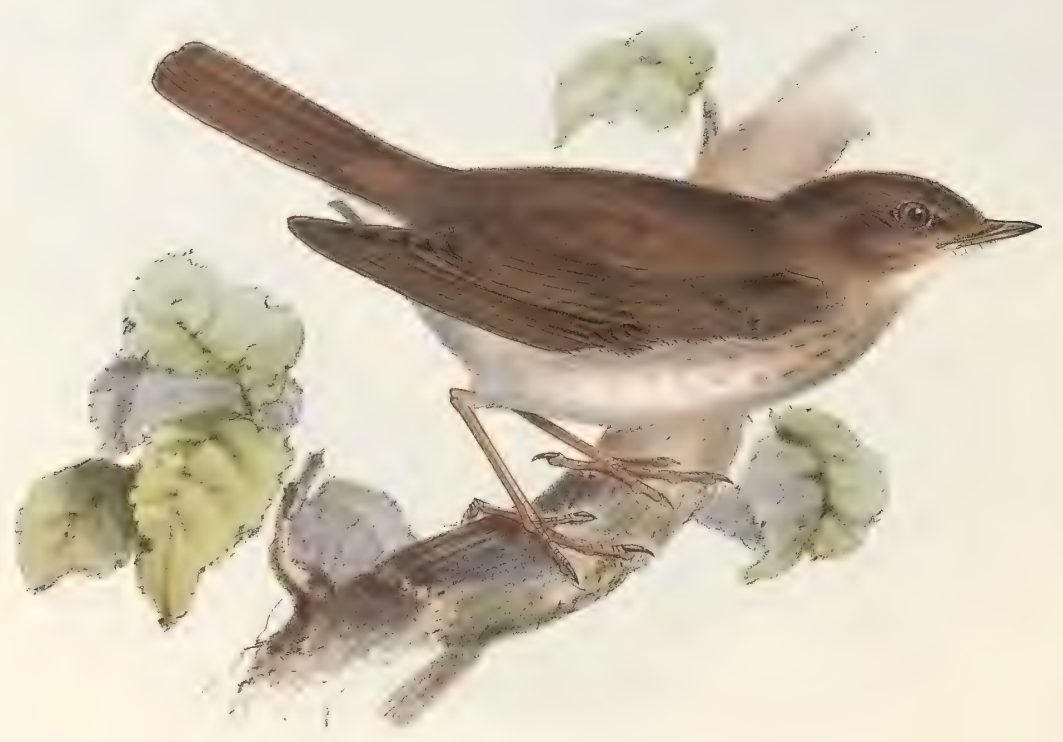

THRUSH NIGHTTINAMEA

Philomela turdoides; (Blyth) 


\title{
THRUSH NIGHTINGALE。
}

\author{
Philomela Turdoides, Blyth.
}

La Bec-fin Philomèle.

IN adopting Mr. Blyth's specific term for this bird, we have been influenced by the desire of paying a just compliment to a young and ardent naturalist, who has taken much pains in elucidating the habits of this, as well as of many other groups in ornithology. "This bird," says he "may be said to connect our Common Nightingale with the Tawny Thrush, or more immediately, perhaps, the Tiny Thrush (M. parva). It is described by Bechstein to have 'the whole plumage generally, and in all parts, deeper and darker than the common species. The head is larger and the beak thicker; the throat white bordered with black; the breast brown, with darker spots ; and it is said, also, to be considerably larger, and longer by about an incl and a half. It is a very loud songster, and sings chiefly by night, but its voice is by no means so melodious as that of the Common Nightingale. 'It has,' continues Bechstein, 'a much stronger, louder, and deeper voice, but it sings more slowly and more unconnectedly; it has not that astonishing variety, those charming protractions and harmonious conclusions of the Common Nightingale; it mutilates all its strains, and on this account its song has been compared to that of the Missel Thrush, to which however it is superior both in softness and purity. The Common Nightingale is superior in delicacy and variety, but inferior in force and strength, while the voice of the larger species is so loud, that it is almost impossible to bear with it in a room.' Its call-note, \&c., as described by the same author, is also very different. 'In cages,' observes Bechstein, ' they are fed like Nightingales, but are less delicate, and generally live much longer;' which, in fact, is another approximation to the Thrushes." And this approximation, we may add, is still further indicated by the spots on the breast.

The habitat of the Thrush Nightingale extends over Silesia, Bohemia, Pomerania, Franconia, and other parts of Germany; it is said to be more abundant than the common species in Hungary, Austria, and Poland ; more rare in France, and never seen in Holland. It is generally found in woods situated on the tops of hills, and also in plains, particularly those in the neighbourhood of running streams.

Like the common species it feeds upon worms, flies, moths, currants, elderberries, \&c. ; the nest is also built in small thickets, but more frequently placed in low and damp situations; the eggs, which are larger than those of the Nightingale, are brownish olive stained with deep brown.

The sexes do not differ in the colouring of their plumage, which may be thus described :

All the upper surface brown; tail rich brownish red; throat whitish; breast clear greyish brown with dashes of dark grey; uıder surface whitish ash; bill brown; legs brownish flesh-colour.

Our figure is of the natural size. 




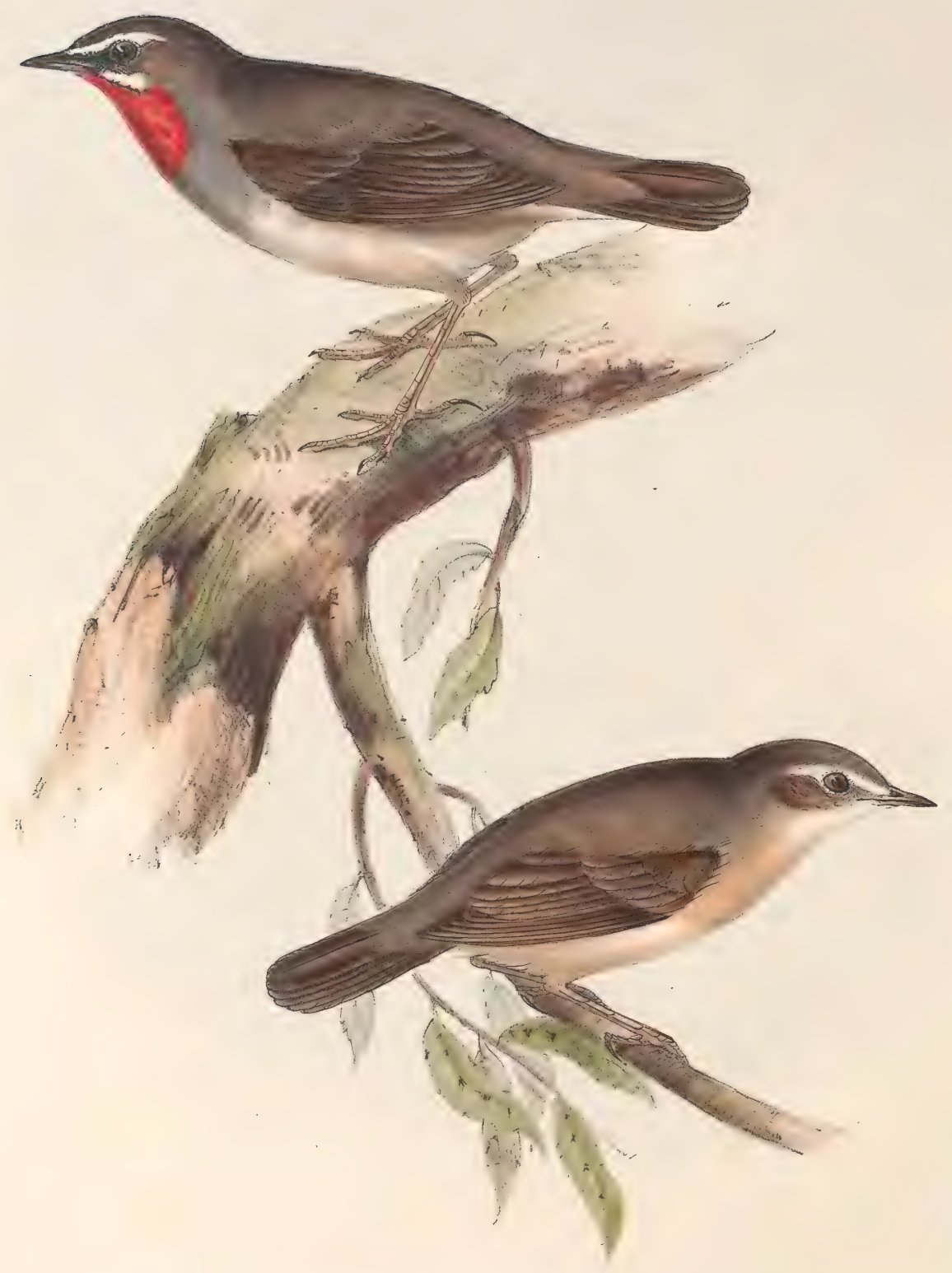

GOPGIF W W W

Calliope Lathamii. 


\section{Genus CALLIOPE.}

GrN. CHar. Bill shorter than the head, straight, compressed laterally and pointed, with a slight indication of a notch near the tip of the upper mandible: base of the bill garnished with a few fine and short bristles. Nostrils basal and oval. Wings rather short and rounded, the first quill very short, the third and fourth the longest. Tail short and rounded. Tarsi long and slender, the hinder toe furnished with a large strong claw.

\section{G O R G T WA R B E R.}

Calliope Lathamii.

La Calliope.

Амом the subdivisions into which the Sylviade are now distributed, we do not find one to which we can strictly refer the present beautiful bird; we have therefore ventured to form a new genus for its reception, taking the specific appellation of Pallas for its generic designation. We cannot perceive its immediate relationship to the Accentors, to which M. Temminck has referred it: both Gmelin and Latham have considered it to be a Thrush (Turdus); but although not ranging with any established genus of that family, its form is very similar to some of the smaller species of that group. In the silky character of its plumage, in the presence of the gorget, and in the great difference between the sexes, it evinces a close affinity to the Blue-throated Warbler (Phoenicura Suecica), but in its general form and contour it approximates to the Nightingale (Philomela Luscinia), to which we consider it to be most nearly allied.

In naming this species after the venerable Dr. Latham, we are influenced by a desire to render a tribute of respect to one who has laboured much in the science of ornithology, and who at an extremely advanced age is now cheerfully passing the remainder of his days in the enjoyment of every domestic felicity, universally honoured by all his contemporaries.

Although the Gorget Warbler has in a few instances been taken within the precincts of Europe, its true habitat is the north-eastern portions of Asia, being a native of Siberia, Kamtschatka, and the island of Japan. Of its nidification and general economy we know but little: it is said to have an agreeable song, which it utters while perched on the topmost branches of trees.

The male has the whole of the upper surface of a uniform olive brown; over the eye a clear stripe of white; a black space between the beak and the eye; a white moustache beneath the eye; from the base of the under mandible a gorget of fine scarlet spreads over the throat; chest greyish brown; flanks brown; abdomen whitish; bill blackish brown; feet light fleshy brown.

The female differs from the male in wanting the black space between the bill and the eye, in the absence of the white moustache, and in being destitute of the beautiful gorget.

The Plate represents a male and female of the natural size. 



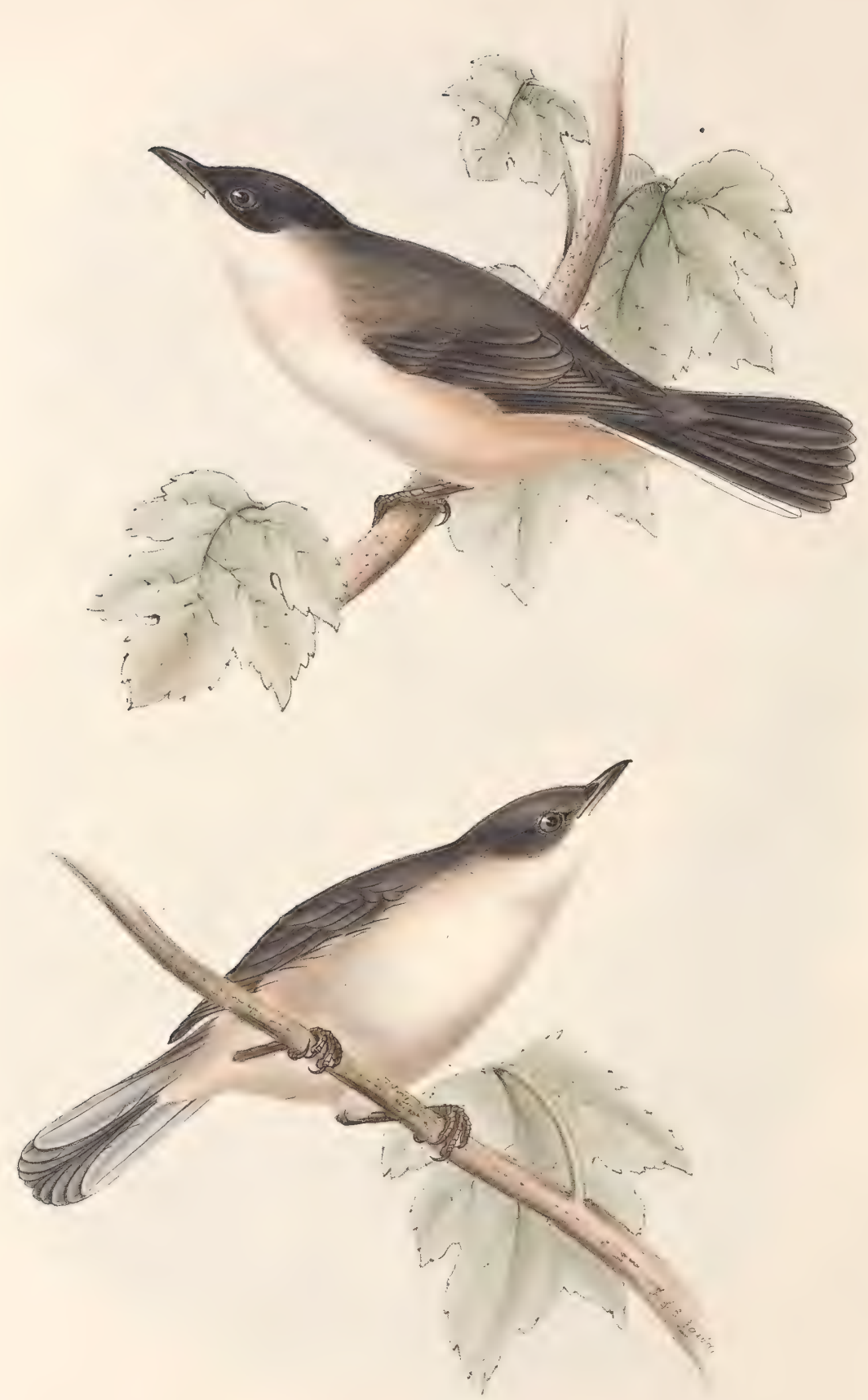

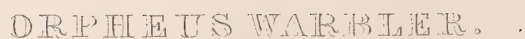

Curtuca (Orphest: M Mihi. 


\title{
ORPHEUS WARBLER.
}

\author{
Curruca Orphea, Mihi. \\ Bec-fin Orphée.
}

Axтнолgн the present species differs in a trifling degree from the more typical examples of the genus Curruca, especially in having a stouter form of beak, which is more deep than wide, we do not feel ourselves at liberty to separate it on such slender grounds, as its general habits and form overbalance the minutiæ alluded to.

The Orpheus Warbler is an inhabitant of the southern provinces of Europe, and we have more than once received it in collections from India. According to M. Temminck, it is very abundant in Italy, particularly in Piedmont and Lombardy, and the southern departments of France. It is accidentally met with in Switzerland and the adjacent districts, but never occurs in more northern latitudes. On referring to the valuable little work of Professor Savi on the Ornithology of Tuscany, we learn that it is there a migratory bird, and much resembles in habits and manners the Common Whitethroat (Curruca cinerea, Bechst.). Its food consists of insects and berries, and it builds in bushes often in company with others of the same species. M. Temminck states, that in addition to bushes it also selects holes in ruins, old walls, or under the eaves of isolated buildings, as a site for incubation. The eggs are four or five in number, nearly white, irregularly marked with yellowish blotches and small brown dots.

The male has the top of the head and ear-coverts brownish black; the whole of the upper surface is of a cinereous brown, with a tinge of olive, the quills and tail being rather darker; the outer feathers on each side of the latter are white, tinged with reddish brown, which prevails more decidedly on the flanks and under tail-coverts.

The female resembles the male, except that the head is of the same colour as the rest of the plumage.

Our Plate represents a male and female of the natural size. 




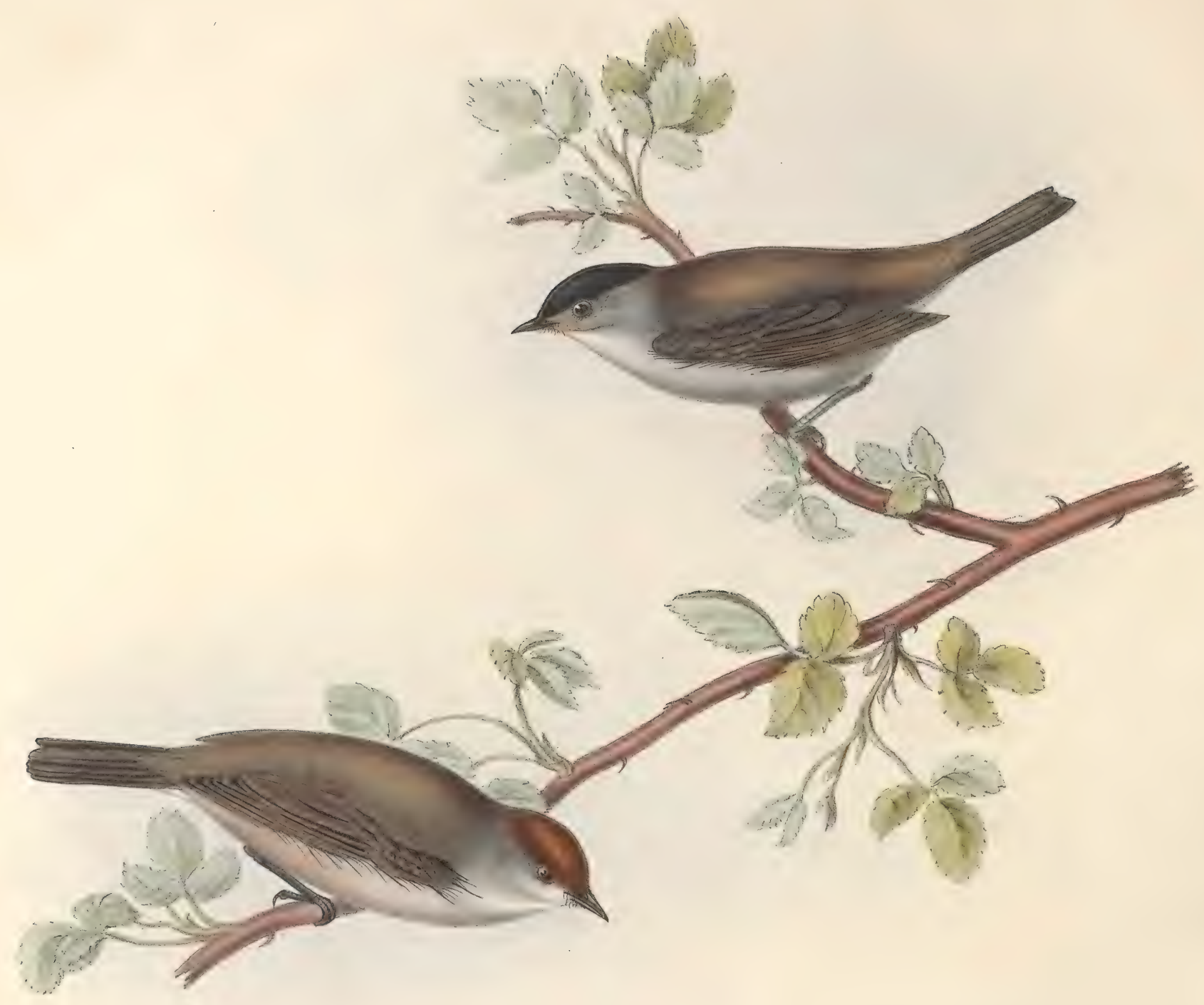

$\mathbb{B} I_{A} \mathbb{C} \mathbb{K} \mathbb{C} \mathbb{P}$ 。

Curruca atricapilla; (Brifs). 


\title{
B I A C K - C A P.
}

\author{
Curruca atricapilla, Bechst.
}

Le Bec-fin à tête noir.

OF the numerous migratory songsters that add a charm to our spring by their melody, the Black-cap is inferior to none, being equally distinguished for the power and variety of his own notes, as for his aptness in imitating those of other species, whether discordant or otherwise, - a habit in which he frequently indulges; and so exactly similar are the sounds he produces, that we are often deceived by the skill of the imitation : his own song is particularly liquid and melodious, and poured out with great energy. The Black-cap is common in our Island during summer, and also generally spread throughout the northern and central portions of Europe; it frequents our gardens and shrubberies, but is nevertheless a bird of shy and recluse habits, and remains concealed from observation in the thickest part of the foliage. It generally appears among us in the month of April, and departs again in September.

It is worthy of notice that the males and females of this species perform their migrations separately ; and we believe this habit is almost universal among the Warblers, the males preceding the females in their arrival by about a week, commencing their song immediately, and selecting a favourable locality for the purpose of nidification, which takes place as soon as the foliage is sufficiently dense for the necessary concealment, among which they construct their nest of vegetable fibres intermingled with a little moss and grasses, in a low bush, shrub or hedgerow, the female laying four or five eggs of a dingy white, clouded with light yellow brown, spotted and occasionally streaked with darker brown. Its food consists of insects, berries, and fruits.

The male has the top of the head and occiput of a deep black ; the throat and under parts of a lightish grey; the upper parts, wings and tail, of a dull olive grey; feet and beak blueish ash. The female has the top of the head reddish brown; the other portions of the plumage like that of the male, but rather more obscure, the under parts having a slight tinge of red pervading the grey.

We have figured a male and female of their natural size. 





\title{
GA R D N W A R B I R
}

Curruca hortensis, Bechst.

\author{
La Bec-fin fauvette.
}

THrs unassuming and plain-coloured bird is one of the migratory species resorting to our island, where it arrives in the month of April, enlivening our gardens, coppices, and shrubberries with its cheerful notes; and with so much melody does it pour forth its strains that it has often been put in competition with the Nightingale and Blackcap.

In its habits it is shy and secluded, seldom showing itself, and its presence is often unsuspected until its soug is heard.

Its range is very general over our island as well as over the whole of the temperate and southern portions of Europe. Soon after its appearance in this country the business of nidification is commenced, the nest being constructed among nettles, or any other rank herbage, and formed of roots, grasses, various other plants and moss interwoven together; the eggs, which are four in number, are yellowish grey, blotched with wood brown, principally at the larger end.

The adults of both sexes do not differ in the tints of their plumage; the young, on the other hand, have the region of the eyes lighter, and the general colour of their plumage more olive.

The adults may be thus briefly described:

Upper surface ash grey, with a slight tinge of olive; sides of the neck ash grey; throat and under surface greyish white; flanks and breast slightly tinged with brown; bill brown; legs greyish brown.

We have figured a male of the natural size. 




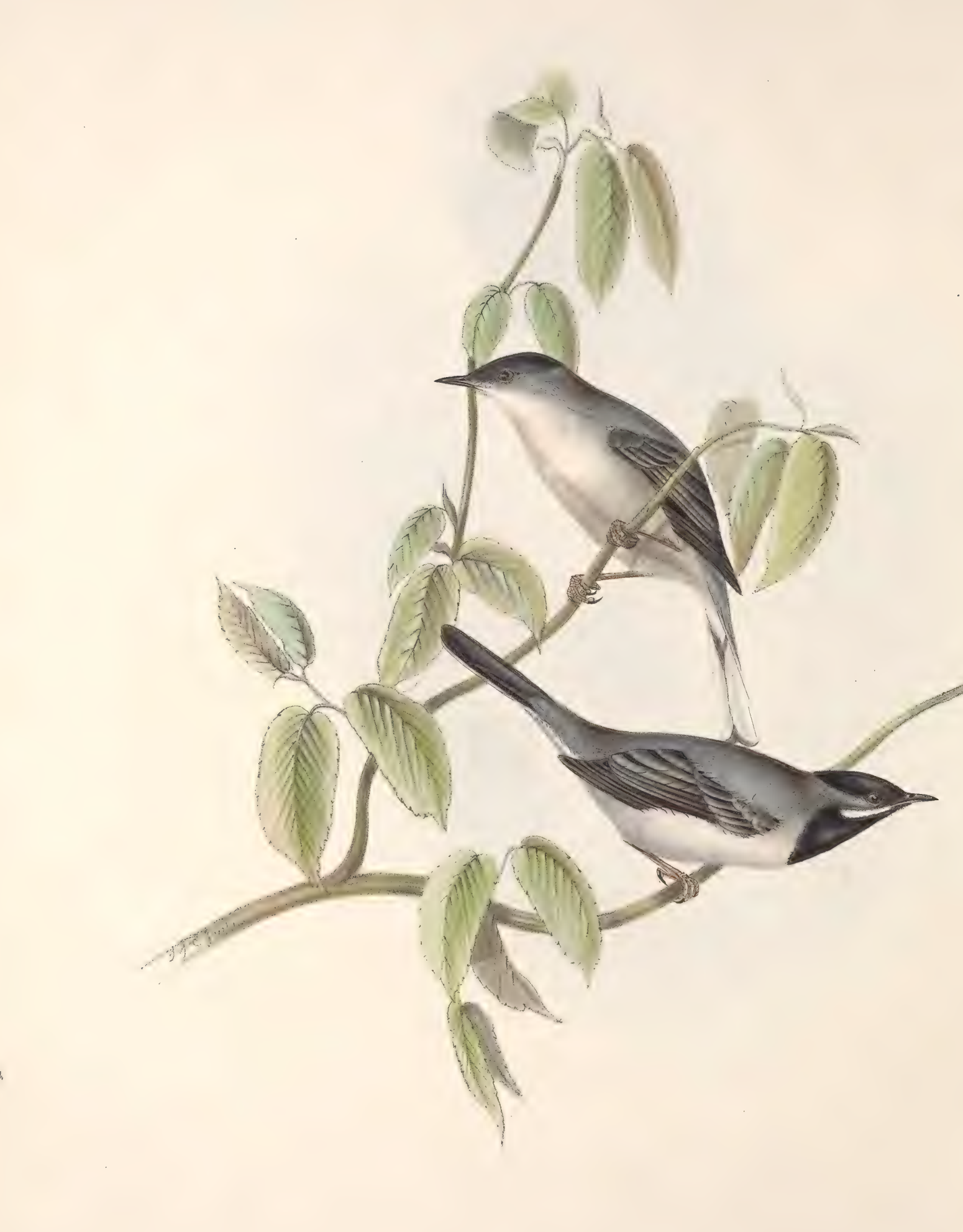




\section{RÜPPELL'S WARBLER.}

Curruca Ruppellii.

Le Bec-fin de Rüppell.

THIs elegant bird having been admitted to the Fauna of Europe as a rare visitant to its eastern countries, it becomes necessary for us to illustrate it in the present work.

The figures in the accompanying plate are drawings of individuals obtained from the collection of Dr. Rüppell, to whom the species has been dedicated by M. Temminck; and we ourselves feel considerable pleasure in being able to assist in perpetuating the name of so distinguished a naturalist, whose exertions in behalf of science cannot be too highly appreciated, and whose enthusiastic researches in the field of nature have enabled him to add so largely to our zoological knowledge.

The habitat of the Curruca Rüppellii would appear to be the northern and eastern portions of Africa, where it occasionally passes over the boundary line to the adjacent confines of Europe.

M. Temminck informs us that it gives preference to thickly wooded districts; and from the general form and contour of the body, and particularly its subdued and sober tone of colouring, we may reasonably expect that its general aconomy is in unison with the birds of our own island to which the restricted term of Curruca has been applied, and with which we have ventured to associate it, acknowledging at the same time that the more slender and pointed bill of the present bird offers a character somewhat at variance with the genus alluded to.

The little knowledge we possess respecting the habits and nidification of this interesting bird prevents our adding to this description that information which future discovery can alone impart.

The sexes, as in many other species of the genus Curruca, offer a marked difference in their colouring, the male being distinguished by its black head and throat, and by the conspicuous stripe of white which passes from the base of the lower mandible to the end of the ear-coverts, which are grey: in other respects they are alike in plumage. The female has only a tendency to the black crown, and is entirely devoid of the white stripe on the cheeks.

The whole of the upper surface is deep blue grey; wings blackish grey, the outer edges of the feathers margined with brown; the eight central feathers of the tail black, the next on each side black on their outer webs with a large white spot on the inner ones, the outer feather on each side white for three fourths of its length; flanks grey; under surface greyish white tinged with vinous; bill black at the tip and brownish white at the base; legs brown.

The Plate represents an adult male and female, of the natural size. 




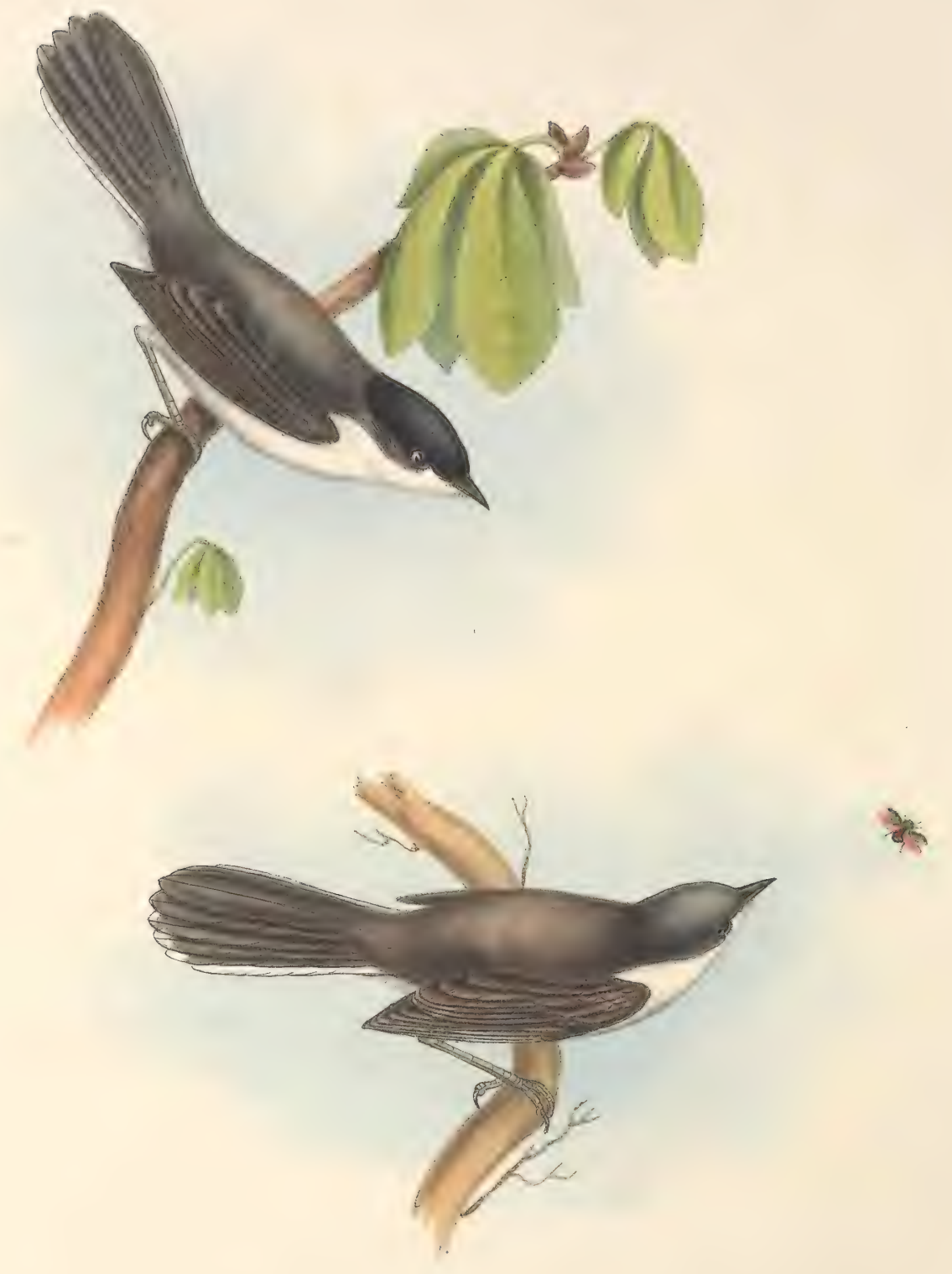

SATRIDINTANY WARTHUR。

Curruca melanocephala, (Bechec\%. 


\section{SAR D I I A N WARB L ER.}

Curruca melanocephala, Lath.

Bec-fin mélanocéphale.

THrs bird, which is closely allied in habits, manners and plumage to our Black-cap, (Curruca atricapilla, ) has hitherto been little known, and is seldom to be met with in ornithological collections. We are able to add but little to M. Temminck's account, who informs us that its localities are very limited, as it appears to be confined to the central parts of Spain, Sardinia, and the Neapolitan States; a circumstance which seems the more probable, as the author has never yet seen it among any of the numerous and extensive collections from different parts of the globe which he has had the opportunity of inspecting.

The specimens from which the accompanying figures are taken were brought from Spain, in 1831, by Captain S. E. Cook, who observed the species to be not uncommon in the neighbourhood of Madrid, and in the interior of the country. By that gentleman they were presented to the Zoological Society of London; and the Author here takes the opportunity of expressing his obligations to the Council and Members, for the permission so kindly allowed of availing himself, on this and other occasions, of the treasures of their Museum. Its food, like that of the Black-cap, consists of flies, the larvæ of insects, and soft berries ; but we are unable to say whether or not it is as sweet and charming a songster as our own British species. It builds in low bushes near the ground, the female laying five eggs of a yellowish-white, spotted with a darker colour.

The male and female differ not only in the colour of the head, but also in the general tinge which pervades the plumage. In the male, the forehead, top of the head, and ears are of a deep black; the rest of the upper surface of a dark leaden grey; the quill-feathers tinged with brown; the tail inclining to black, the outer feather on each side having its tip and outer edge dull white; the throat white; the sides grey, becoming lighter on the under surface; the legs light brown; irides brown; beak black, base of the under mandible whitish.

In the female, the top of the head is of a dark leaden grey, like the back of the male; the whole of the upper surface is tinged with olive-brown; the throat white; the sides light russet brown, becoming lighter below; the beak and legs as in the male.

The length is about five inches.

The Plate presents a male and female of the natural size. 




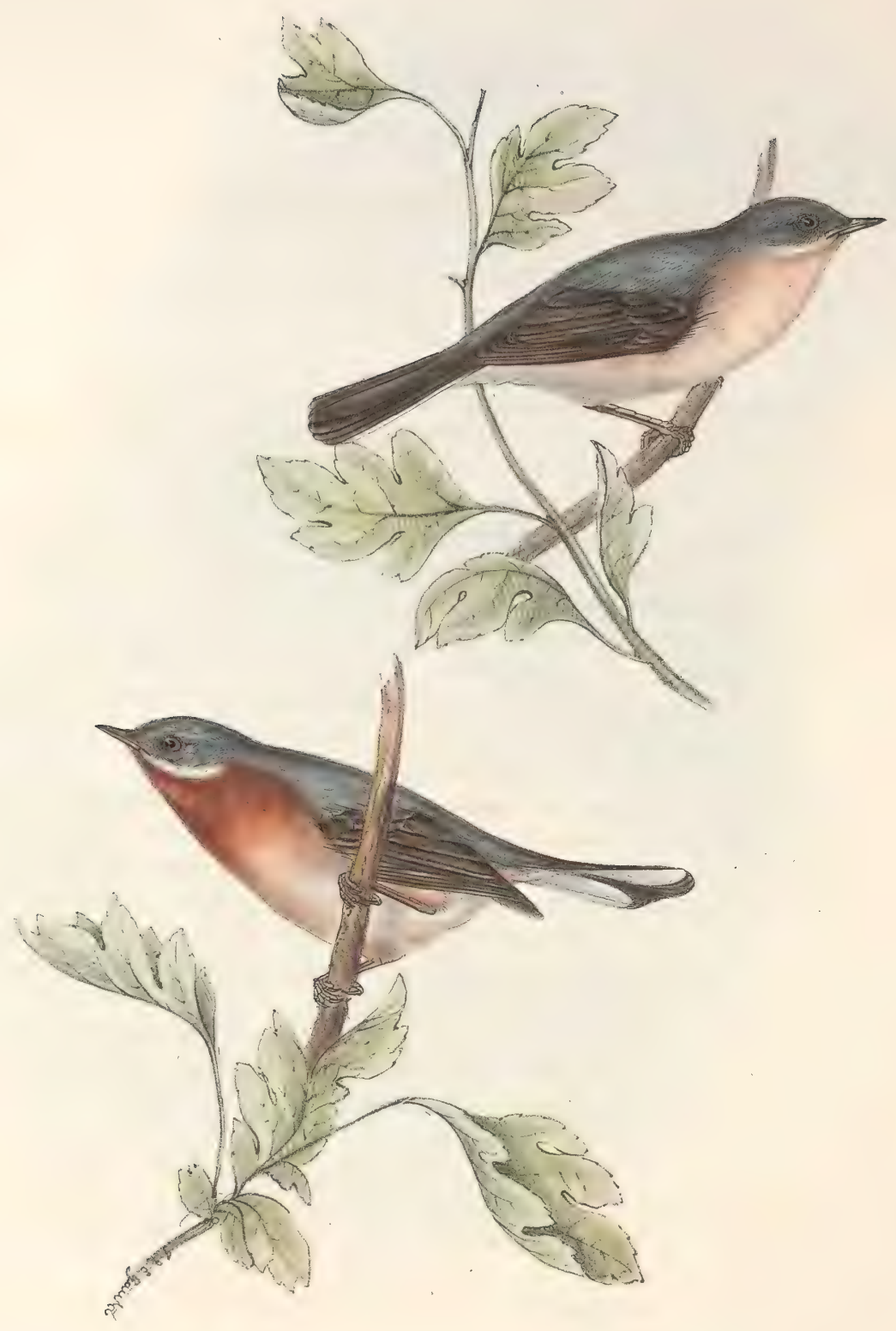

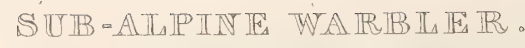

Curruca leucopogon; (. Mihi). 


\title{
SUBALPINE WA RBIER。
}

\author{
Curruca leucopogon, Mihi.
}

Le Bec-fin subalpin.

$W_{\mathrm{E}}$ are indebted to the collection of the Zoological Society of London for the first examples of this species which we have had the opportunity of examining, and which were presented to the Museum by the celebrated Professor Savi, of Pisa, who, in his work on the Birds of Tuscany, states, that the Sylvia passerina and S. subalpina of M. Temminck's Manuel should be considered as synonymous with the Sylvia leucopogon of Meyer. We have also more recently been favoured by M. Temminck with fine examples of this species, and with a communication in which he acknowledges that recent observation has established the justice of Professor Savi's opinion, in considering his Sylvia subalpina as the old male in the livery of spring of the Sylvia passerina, and which, as we have before stated, Professor Savi considers synonymous with $S$. leucopogon, being the same bird in different stages of plumage. It appears, indeed, to be a bird whose changes of plumage are not yet rightly understood, even by those who have had the best opportunities of observing it in a state of nature. Professor Savi has forwarded specimens of this interesting bird in different states, one of which certainly answers to the description of the $S$. passerina of M. Temminck.

The figures which we have given to illustrate this species are those of adult birds of both sexes, killed in summer. The female will be seen to offer a contrasted difference to the male in the colour of her plumage, which offers no very great dissimilarity to that of the young, except that the blueish grey of the upper surface is of a reddish brown tinge, the flanks also in the young being of a more sandy yellow. We trust it will not be considered that we have added new difficulties by increasing the synonyms which have already been applied to this species, in adopting the generic station and title of Curruca, which we do provisionally, considering that it is closely allied to the typical form of that genus.

The natural habitat of the Subalpine Warbler is limited to the South of Europe, especially Italy and Sardinia : it is also known to exist in considerable abundance on the banks of the Nile, as far as Abyssinia. It frequents bushes and underwood, living upon insects, small caterpillars, \&c. Of its eggs and nidification nothing is at present known.

The male, in full plumage, has the head and the whole of the upper plumage of a fine blueish grey; the wings and tail somewhat darker, the feathers of the wings having lighter edges, and the two outer tailfeathers being pure white; the throat, breast, and flanks are reddish chestnut; a white moustache passes from the angle of the beak to the side of the neck; the middle of the belly dirty white.

The female differs from the male in having the breast only tinged with pale rufous, the white moustache being much more obscure.

The young, as we have already stated, differs from the female in having the upper plumage of a more uniform greyish brown, and in being much more pale beneath.

The Plate represents the male and female of the natural size. 




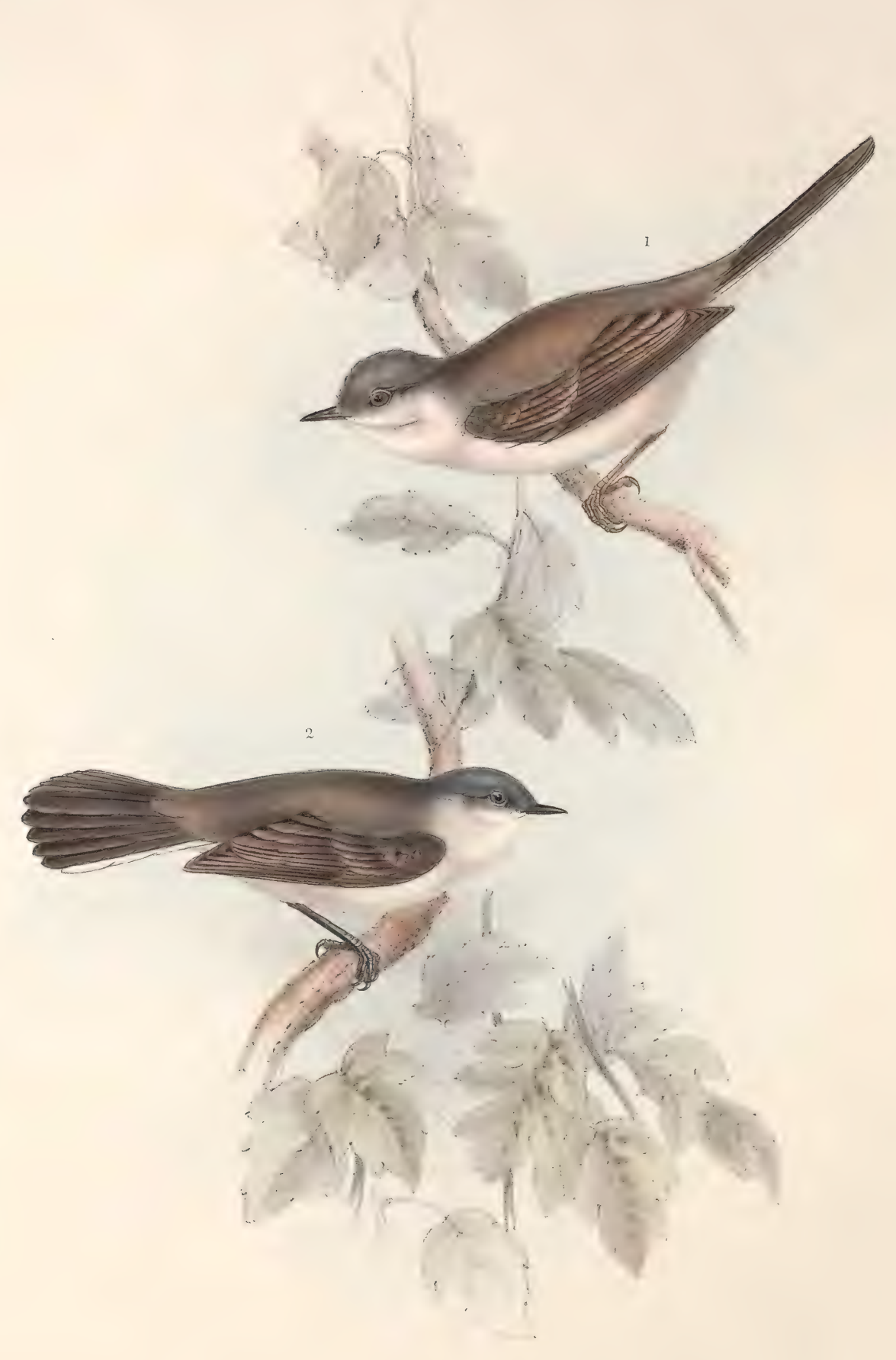

1. COMIMDN WHIT $\mathbb{E} \mathbb{T} \mathbb{R} \mathbb{R} \mathbb{A} \mathbb{T}$. Curruca cinerea: (Bechst)

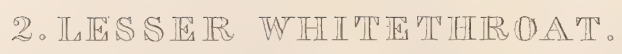
Curruca garrula: (Bechsot.) 


\title{
COMMON WHITE-THROAT.
}

\author{
Curruca cinerea, Bechst. \\ Le Bec-fin grisette.
}

OF all the migratory birds which pay their annual summer visit to this country for the purpose of making it their home during the breeding season, the Common White-throat is by far the most abundant and the most extensively distributed, every hedge-row and coppice being enlivened by its presence. It is no less abundantly found throughout the mild and southern districts of continental Europe. Like many other birds of the genus in which it is ranked, it has the power, to a considerable degree, of imitating the notes of other birds independent of its own hurried, confused, and babbling strain. During the time the female is engaged in the task of incubation, the male may be seen mounting in the air to a considerable height above the tops of the hedges with a singular jerk of the tail and raised crest, uttering its song, if a series of rapid and intricate modulations may be thought worthy of the name. Among the entangled branches and thick foliage of hedge-rows it displays the utmost quickness and address,-concealing itself from observation with great wariness: to hedges, indeed, particularly those which border lawns or broad ditches overgrown with nettles and other wild plants, the Common White-throat always appears to be partial; it generally constructs its nest in such situations, and uses for its materials dry grass and bents loosely interwoven, and though by no means remarkable for beauty or elaborate workmanship, its little building is frequently so well concealed as to require a pretty close scrutiny to discover it; the eggs are generally four or five in number, of a pale blueish white, thickly speckled with ash-grey. The young at a very early age nearly resemble their parents, between whom no difference exists either in the colour or the disposition of the markings of their feathers.

The general plumage of the whole of the upper parts is of a rufous grey, the edging of the secondaries being of a brighter tint; the quills and tail-feathers of a darker hue with less of rufous; the throat is white, the under parts white, tinged especially on the breast with a slight wash of rufous; irides hazel; beak and tarsi wood brown.

\section{LESSER WHITE-THROAT.}

\author{
Curruca garrula, Bechst. \\ Le Bec-fin babillard.
}

T'He Bec-fin babillard, Syllyia Curruca, Temm., Babbling Warbler of Latham, and the Lesser White-throat, are all synonymes of the Curruca garrula of Brisson. In size, as its English name implies, it is considerably less than the Common White-throat, which, however, it greatly resembles in general habits and manners, but appears to be more partial to orchards, gardens, and coppices, where it frequents the tallest trees, pouring out its babbling notes with the utmost energy, but never, we believe, rising in the air and singing at the same time, as is so remarkably the case with the preceding species; its notes are also more powerful and melodious, and its disposition more restless. It is neither so abundant nor are its local resorts so extended in the British Isles as the Common White-throat; it inhabits in preference the warmer portions of continental Europe, and in England confines its visits to the southern counties of our Island, becoming more and more scarce as we proceed northward, where beyond a certain limit it is unknown. The situations in which it builds are similar to those chosen by the Common White-throat; such as bushes, brambles, nettles, \&c., where it forms a nest of bents and other grasses, lined with finer fibres partially mixed with hair. The eggs are four or five in number, of a white colour dotted and blotched with ash-grey and brown, except at the small end, which is plain. This species, as well as the preceding, leave this country in the months of August and September.

The top of the head is pure ash colour, becoming deeper on the ear-coverts; the general plumage above is greyish brown inclined to olive; the throat pure white; the under surface white very slightly tinged with brown; irides hazel; beak and tarsi lead colour. The male and females are alike in colour.

Our Plate represents both the Common and Lesser White-throat in their spring plumage, of their natural size. 



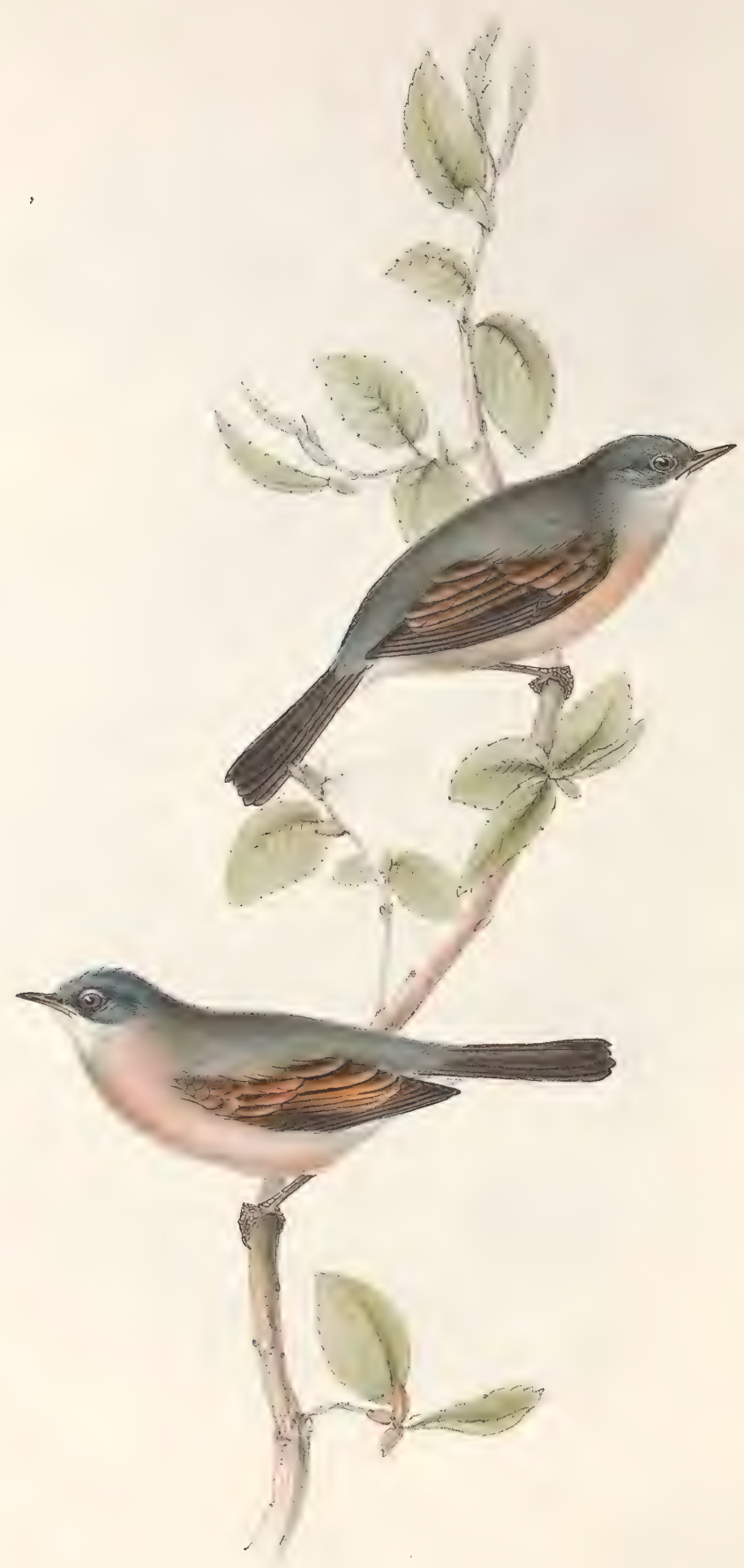

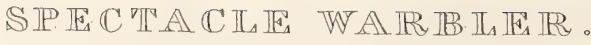
Curruca conspicillata. 


\section{SPE C T C L E WAR BIER.}

Curruca conspicillata, Mihi.

Le Bec-fin à lunettes.

THis elegant little bird, which in form and general style of colouring is so nearly allied to the common Whitethroat, Curruca cinerea, is an inhabitant of the southern provinces of Europe. We have seen several specimens, killed in Spain, where, according to the observation of Capt. S. E. Cook, R.N., (see "Sketches in Spain," vol. 2. p. 264.) it is far from being uncommon. "This beautiful little bird," he observes, "is stationary in Andalusia, frequenting low and moist situations, and, I suspect, not much extended in their habitats. I found them in the marshes near Seville, where they live with the $C$. cinerea, and may easily be mistaken for them."

In addition to the above authority we have other grounds for stating the close resemblance of its habits and manners to those of our Whitethroat; and though we have no information as to its song or nidification, it may be reasonably presumed that in these respects also it exhibits a decided alliance. According to MM. Savi and Temminck, it is found in Sardinia, where it may be observed in places covered with bushes or wood: in the North of Italy and France it has never been seen.

The male has the top of the head and cheeks fine ash colour; the space between the eye and the beak black, whence a circle of the same colour surrounds the white of the eyes; the upper surface vinous ash colour; the wings blackish, edged with rufous; throat white; under surface white, tinged with vinous, which passes into reddish on the flanks; tail somewhat graduated, and brownish black, with the exception of the outer feathers, which are nearly white, the second and third being also tipped with the same colour.

The female is only to be distinguished from the male by the paler colouring of the plumage, which still preserves the markings of the male, except that the circle of black round the eyes is scarcely if at all apparent.

Our Plate represents an adult male and female of the natural size. 




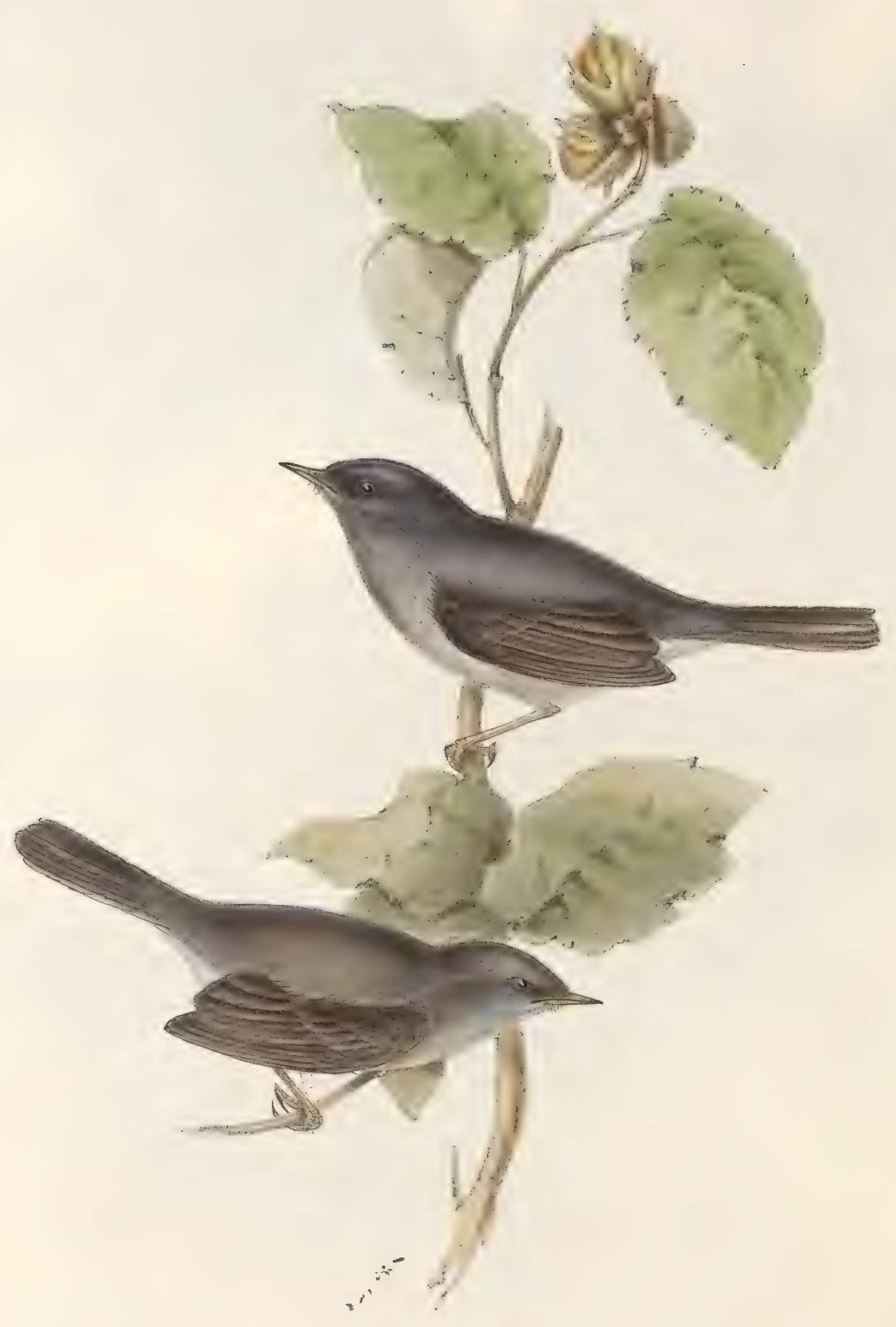

$M I \mathbb{R} D \mathbb{R} \mathbb{A}^{\circ} S W A \mathbb{R} \mathbb{R} \mathbb{R}$.

Curruca sarda. 


\title{
MARMORA'S WARTLR。
}

\author{
Curruca Sarda. \\ Le Bec-fin Sarde.
}

IN his "Manuel d'Ornithologie" M. Temminck informs us that we owe the knowledge of this species to the Chevalier Marmora, and that it was described " in the Annals of the Academy of Turin, on the 28th of August 1819. In its plumage and by the naked circle round the eyes, it is nearly allied to the Sylvia melanocephala, from which it is distinguished by its beak being more feeble and slender, like that of the Pittchou. It may also be distinguished by the tail, of which only the exterior feathers are edged with white, whilst in the Becfin melanocephala all the exterior barbs and the ends of the two first feathers are white. The colour of the throat also prevents these nearly allied species from being confounded."

In addition to the features pointed out by M. Temminck to distinguish this bird from Curruca melanocephala, we may observe that in the latter the black colouring of the head is more decided and of a deeper tint than in Curruca Sarda, which has the whole of the upper plumage of a uniform blackish grey.

Although this bird is somewhat rare, it may be found in most of the European collections; and from the circumstance of our never having observed it in any of the numerous and extensive collections from India and Africa which we have had the opportunity of examining, we feel convinced that it is a very local species, apparently only found in Sardinia and the most eastern portions of the Continent.

It is said to dwell in small woods, and to feed on very small flies and other insects, which attach themselves to the leaves.

Of its nidification nothing is known.

In the colouring of their plumage the sexes present but a slight difference, the male being only of a somewhat darker tint, particularly on the throat and under surface.

The head, throat, and all the upper surface is of a deep blackish grey, which is darkest on the forehead and round the eyes, the sides of the neck and flanks being much lighter, and having a tinge of vinous; middle of the belly greyish white tinged with vinous; wings and tail black, the exterior feathers of the latter edged with white; the orbits of the eyes naked and of a beautiful vermilion; base of the under mandible yellow, the remainder blue; feet yellowish brown.

We have figured a male and female of the natural size. 




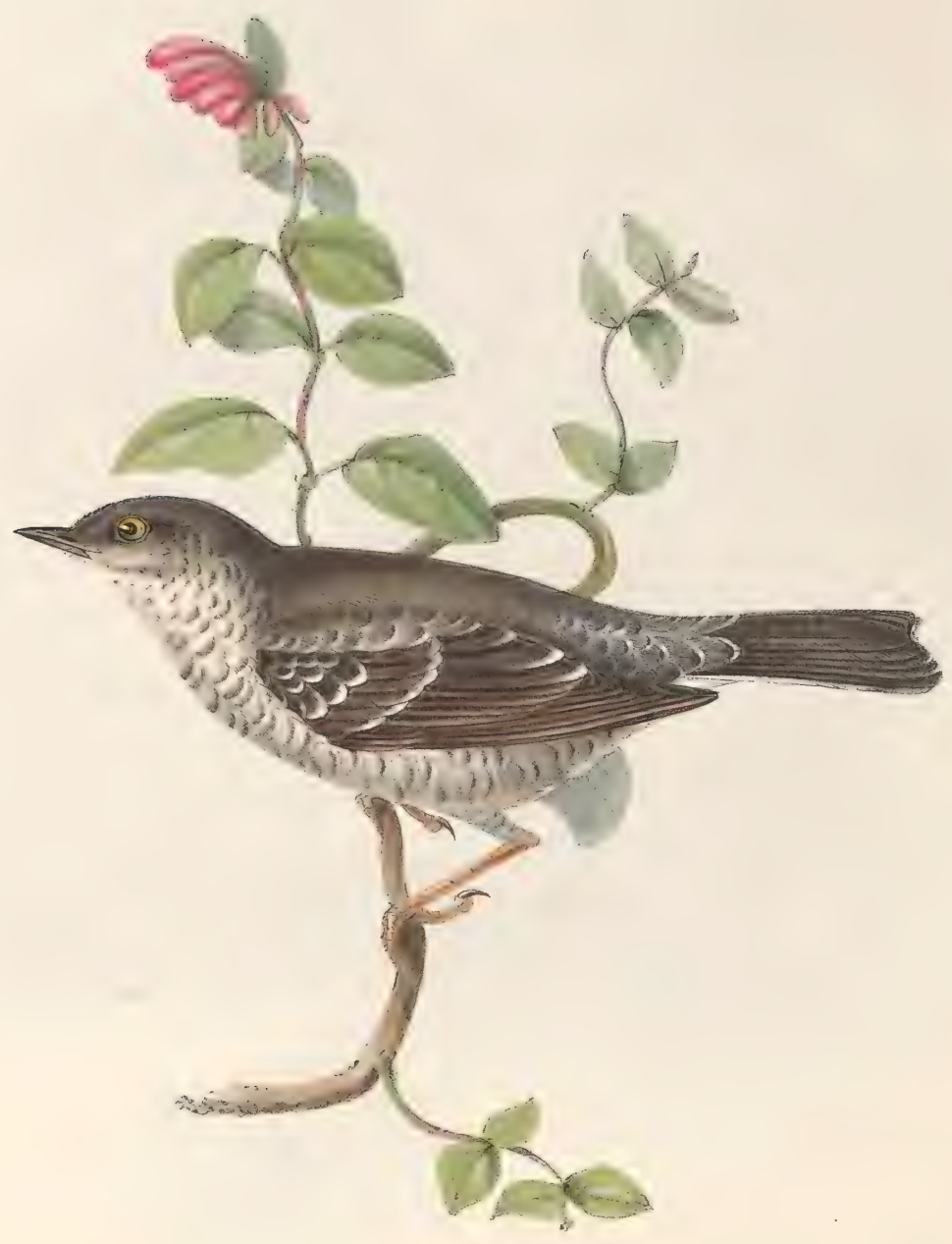

$\mathbb{B} A \mathbb{R} \mathbb{R} \mathbb{E} \mathbb{W}$ WA $\mathbb{R} \mathbb{R} \mathbb{A} \mathbb{R}$ 。

Curruca misoria. 


\section{BA R R D W A R B L ER.}

Curruca nisoria.

Le Bec-fin rayée.

THE principal feature peculiar to this rare species consists in its comparatively large size to that of the Warblers in general, in its lengthened and elegant form, and in its grey tone of colouring, relieved by numerous transverse bars of black and white. In assigning it to the genus Curruca, which we do with some hesitation, we are influenced by the fact that of all the groups of the Sylviada, it is to this that it makes the nearest approach. It is not a native of the British Isles, nor, as far as we are aware, has it been found in France or Holland; it is, however, tolerably common in many parts of Germany. Never having, ourselves, seen this bird in a state of nature, we prefer quoting the observations of $\mathbf{M}$. Temminck, who informs us that it inhabits bushes and thickets, is abundantly spread throughout the North, occurring in Sweden and in the provinces of the North of Germany and Hungary: it is of more rare occurrence in Austria, and it is also found in Lombardy.

Its food consists of insects, caterpillars, worms, and berries.

It builds its nest in tufted hawthorn bushes, lays four or five eggs, of a whitish colour blotched with purplish ash or pure ash colour.

M. Temminck describes the male and female as offering considerable difference in the marking of the plumage. In the specimens that have fallen under our notice this difference has appeared but very trifling. It may be best, however, to give the colouring from M. Temminck. That of the adult male is as follows :

Head, cheek, back of the neck, and back, of a deep grey, as are also the scapulars and rump, but all the feathers of these parts are terminated by a small bar of brown and another of white; the wings are of a lighter ash colour, the outer feather having a large blotch of white at its extremity; this blotch of white is not so apparent on the second, and still less so on the third and fourth feathers: all the under surface is whitish transversely barred with ashy grey; under tail-coverts are grey with large white edges; beak brown; irides brilliant yellow.

The female has the upper surface of an ash colour, clouded with brown but without transverse bars ; the flanks slightly clouded with reddish; the white at the extremity of the tail is more circumscribed and less pure.

The young before their first moult have the whole of the body marked with minute transverse rays of ashy brown; irides brown.

The Plate represents a male of the natural size. 




$$
\text { \% }
$$




\section{Genus MELIZOPHILUS, Leach.}

GEN. CHAR. Head large; bill short, greatly arched from the base, compressed, with the tip finely emarginated; tomia of both mandibles inflected towards the middle; gape slightly bearded. Nostrils basal, lateral, longitudinally cleft. Wings short, rounded, the first feather very small, the second shorter than the third, fourth, and fifth, which are equal and longest. Tail long and soft. Legs having the tarsi strong, and longer than the middle toe, which is nearly equal in length to the hind one.

\section{DARTFORD WARBLER.}

Melizophilus provincialis, Leach.

Le Pitte-chou de Provence.

$W_{\mathbf{E}}$ adopt the present genus as constituted by Dr. Leach, in the formation of which we consider him borne out by the striking difference this bird exhibits in its characters to all the other European Sylviadce. Its form closely allies it to the Superb Warblers (Malurus, Vieill.) of New Holland, while its relationship to the Common Whitethroat, Curruca cinerea, is strikingly apparent: its rounded wing and very graduated tail, however, form just grounds of distinction. To the British Ornithologist, the Dartford Warbler is a bird of peculiar interest. It is a permanent resident in this island, a fact which is proved by our having received it in a recent state at all seasons of the year. It is nevertheless far from being universally distributed, being principally, if not exclusively, confined to the southern and south-western districts, where it resorts to commons, heaths, and moorlands, clothed with thick furze and heather, living in a state of complete seclusion, being habitually addicted to threading the thickest portion of the brushwood, whence it is not easily driven. In the spring, at the season of pairing and nidification, it is more lively and more frequently visible, rising on quivering wing above the tops of the furze, and uttering a hurried babbling song, much after the manner of the Whitethroat; at these times it erects the feathers of its head into a crest, and distends the throat, exhibiting various attitudes and gesticulations. The nest is composed of dry stalks and grass, intermingled with wool and vegetable fibres : it is in general placed in the thickest part of a furzebush, at a short distance from the ground. The eggs, according to Montagu, are very similar to those of the Whitethroat, being speckled with brown and cinereous spots on a greenish white ground.

The Dartford Warbler is found tolerably abundant on all the heathy commons in the immediate vicinity of London, as well as those of Bagshot, Chobham, \&c., but it is more particularly abundant in Devonshire and Cornwall. In no place, however, is it to be found more plentiful than in the neighbourhood of Oakingham in Berkshire, whence specimens have been sent us by John Rogers Wheeler, Esq., whose fine and choice collection contains the most beautiful examples. On the Continent it is more abundant throughout Spain, Italy, and the South of France, than in Germany and Holland.

Its food consists of various species of insects and their larvæ, to which are added, as the season affords, berries and fruits of various kinds; at least they feed on such substances in confinement where they become tame and reconciled.

The head, the back of the neck, and the upper plumage deep grey; the under plumage deep reddish brown, with a ferruginous tint; throat mottled with white; wings and tail brown, with the exception of the outer feathers of the latter, which have white tips and exterior edges; bill yellow at the base, black at the tip ; legs brown.

The female resembles the male, except that her plumage is duller, the back being dusky brownish, and the throat merely exhibiting traces of the white edging to the feathers so conspicuous in the male.

We have figured a male and female of the natural size. 




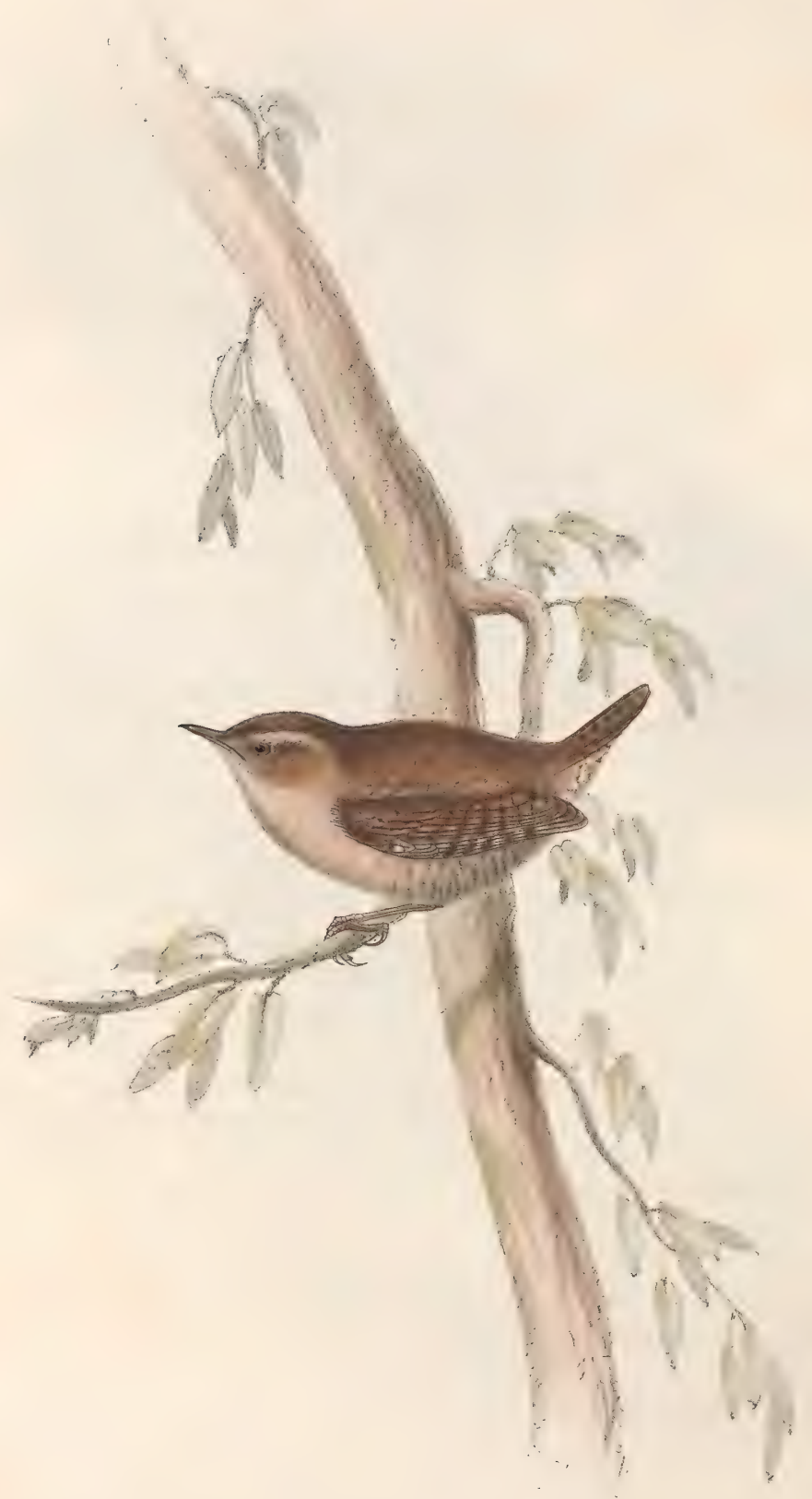

Troglodytes Europæus: (Gu / 


\section{Genus TROGLODYTES, Cuv.}

Gen. Char. Bill slender, slightly compressed, emarginated, curved slightly. Nostrils basal, oval, half covered by an arched and naked membrane. Wings short, rounded; first quill very short; second longer; fourth and fifth equal and longest. Tail short, rather rounded, and carried erect. Legs strong. Toes three before and one behind; the outer toe joined at its base to the middle one.

\section{W R E N.}

Troglodytes Europæus, Cuv.

Le Troglodyte ordinaire.

Aцтноуян the group to which this familiar little bird belongs is filled up by numerous species in the continent of America;-Europe, and even the older continents of Asia and Africa, present us with only one example; a species, however, which in Europe is universally diffused, inhabiting the countries which border the arctic circle as well as those of the South. In England it abounds in our hedgerows and thickets, hovering about the dwellings of man, with whose presence it seems perfectly reconciled, and near whom it is allowed to dwell unmolested. No one indeed can observe its habits and manners without becoming interested in its welfare, enlivening as it does the bleak season of winter with its tremulous, shrill and lively strains; nor is it less amusing to observe it creep like a mouse through our quickset hedges and underwood, examining the mosscovered banks and stumps of trees in search of its insect food which lies concealed among the crevices.

It seldom takes long flights, but keeps to the same local situations. It remains with us during the whole of the year, braving our severest winters with impunity. It breeds early, and its familiar disposition often leads it to build in outhouses, arbours, summer-houses, and similar situations; at other times it selects the sides of walls covered with ivy, and thickly wooded shrubs. It constructs an ingenious and curiously domed nest, of moss, leaves or grass, in fact of any material that may be at hand, and lays seven or eight eggs of a pure white, prettily freckled with reddish spots. The young on leaving the nest are extremely shy, and active in concealing themselves among the herbage and the thickest parts of bushes. The sexes offer no external differences, and the young very soon assume the adult plumage.

The ground-colour of the Wren is of a reddish brown, becoming paler and more grey beneath; the whole of the plumage is prettily barred transversely with darker brown or black; a narrow white line passes above the eyes.

We have figured an adult bird of the natural size. 



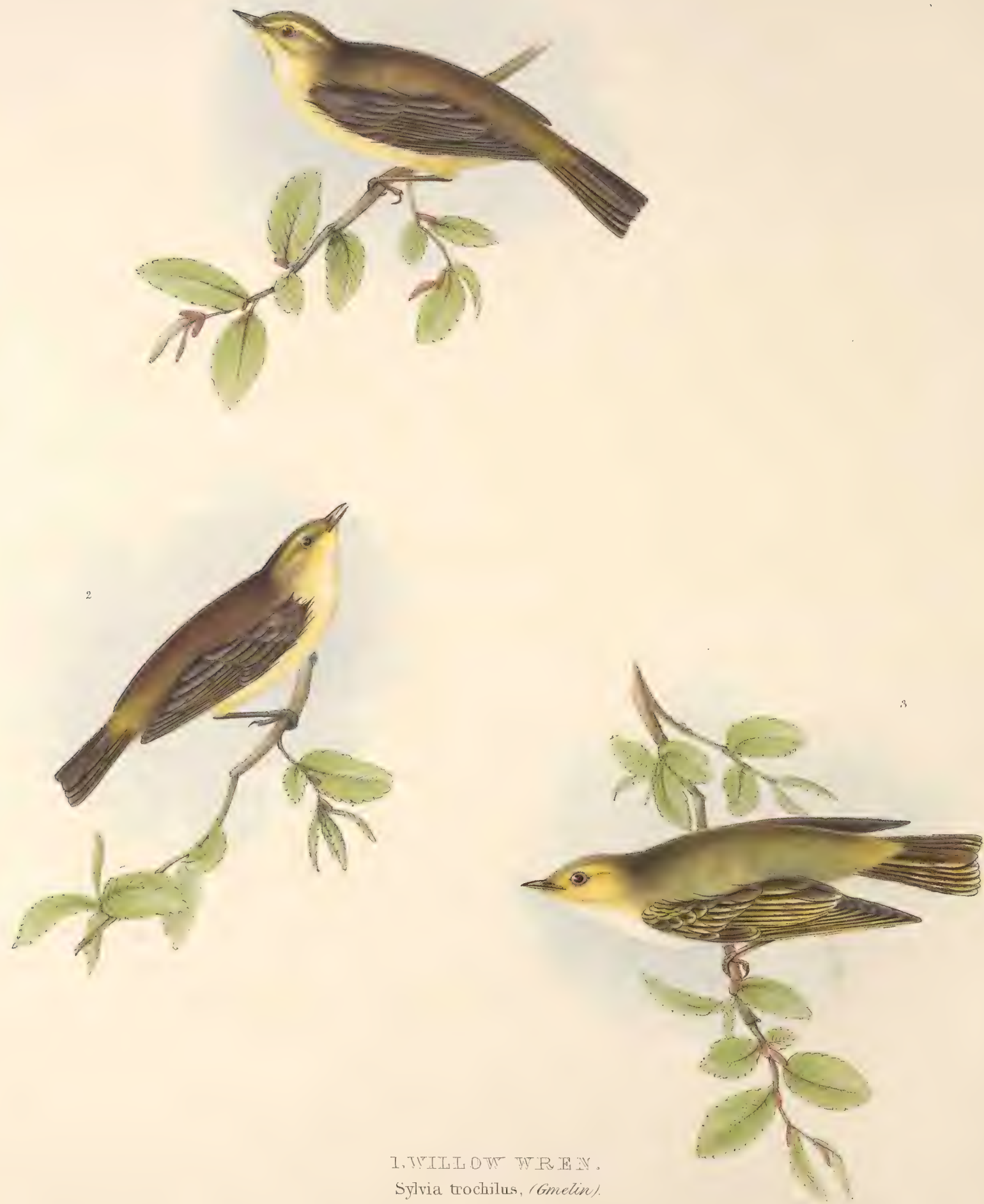

Sylvia trochilus, / Gmetin.

2. CHUFF CHAFT:

Stricia hippolais (T)ath\%.
3. WOOD WREN.

Sylvia sibilatrix, (Bechet). 


\title{
Genus SYLVIA.
}

Gen. Char. Beak straight, slender, conical, pointed, slightly notched at the tip, sides somewhat concave, base furnished with fine hairs. Nostrils basal, lateral, oval. Tarsi longer than the middle toe. Toes, three before, one behind; the outer toe joined at the base to the middle one. Wings, the first quill-feather very short, second and fourth equal, third longest.

\section{W ILLOW WREN.}

\author{
Sylvia trochilus, Gmel. Le Pouillot.
}

WE here present, on a single Plate, three little birds, which are nearly allied to each other in habits, manners, and plumage, and which form the British portion of a genus to which the generic title Sylvia is truly applicable. They visit our budding woodlands on the return of spring, pleasing us with their sweet and delicate notes

The sexes present no difference in plumage; the young, however, in the autumn have a brighter and more pervading tinge of yellow. All are migratory.

The Willow Wren is by far the most abundant in England : it is also dispersed throughout the greater portion of Europe, from Sweden to Italy. At the same time its localities are less strictly confined, inhabiting not only groves, woods, and willow plantations, but gardens, hedge-rows, and commons covered with bushes. It arrives in April; but like the rest of our summer visitors, its appearance seems regulated by the temperature of the season, and the consequent abundance of its food, which consists of the soft-winged insects and their larvæ. Being more familiar than the two others, we have a better opportunity of becoming acquainted with its habits. Its song is simple, consisting of a few prolonged and softly modulated notes, frequently singing while in active search for Aphides and other insects on which it subsists.

The whole of the upper surface is of a greenish-olive : over the eye extends a faint yellow stripe; throat and breast slightly tinged with yellow; belly yellowish-white; under tail-coverts yellow; legs dull fleshcolour; wings covering about a third of the tail.

The female builds a covered nest of dried moss and grasses, lined with feathers, and artfully concealed on the ground, on the sloping side of a bank, or in a dry ditch, among thick herbage or tangled bushes; the eggs are white, marked with pale reddish spots, more thickly dotted towards the larger end.

\section{HIF F = C H A F F.}

\section{Sylvia hippolais. La Fauvette de Roseaux.}

The Chiff-chaff so nearly resembles the former species as to be frequently confounded with it: it may, however, be distinguished by its smaller size and darker legs; in addition to this, the streak over the eye is less apparent, and the general plumage not so finely tinged with yellow.

It is one of our earliest visitors, and is less common than the two other species, differing from both in its habits and localities. Partial to groves and tall trees, it frequents the topmost branches, where it may be heard to utter its short song, composed of two distinctly repeated notes, chiff-chaff, which have given origin to its usual name. In the construction of its nest, and in the colour and number of its eggs, it resembles the preceding species, the spots only being of a darker red, and fewer in number.

In addition to the three species here figured, Bewick adds another, under the title of the Least Willow Wren, which we, however, believe to be a Chiff-chaff.

A little variation frequently occurs in the size of each of these birds. The present is, however, shorter than the Willow Wren by about half an inch, and proportionally less in all its other measurements.

Its habitat is extended to the greater portion of Europe, from Sweden to France.

\section{WOODWREN.}

\author{
Sylvia sibilatrix, Bechst. $\quad$ Le Bec-fin siffleur.
}

THE distinguishing characters of the Wood Wren consist in its superior size, and the more elongated wing, which extends over nearly two thirds of the length of the tail; in the bright yellow streak above the eye, the yellow edgings of the wing-feathers, and the silvery whiteness of the under surface. In other respects its plumage partakes of the general tone of colour which is found in the Willow Wren and Chiff-chaff, except that the olive-green of the back and upper parts is of a more lively tint. Secluded woods and groves are its general places of resort, where it may be easily identified by its peculiar tremulous warble, both louder and possessing more variety than its congeners, and accompanied with a singular quivering of the wings.

Its nest partakes of the character of those of the other species, both as to its structure and place of concealment, but instead of feathers, is lined most commonly with fine grass or hair. The eggs are six in number of a white ground, dotted with purplish spots, more confluent towards the larger end.

It inhabits the same countries as the two preceding species. 




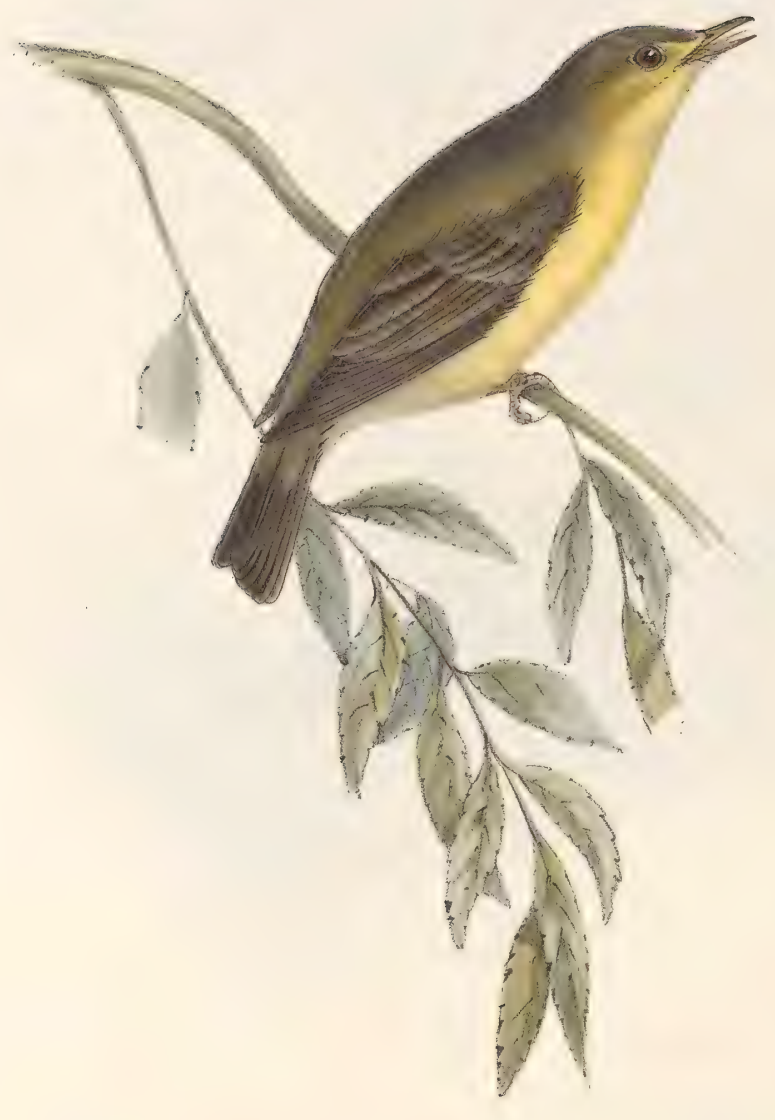

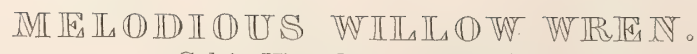

Sylvia Hippolais: (Temm:) 


\title{
MELODIOUS WILIOW WREN.
}

\author{
Sylvia Hippolais, Temm. \\ Le Bec-fin à poitrine jaune.
}

THE bird which we have figured in the accompanying Plate appears to be the true Sylvia Hippolais of M. Temminck and other Continental writers, and is a species which has hitherto never been found in England; the bird known under the above name in our island being now unanimously acknowledged to be the Sylvia rufa. It is somewhat singular that this species, so familiar to every naturalist on the Continent, and which inhabits the gardens and hedgerows of those portions of the coasts of France and Holland that are immediately opposite our own, should not, like the rest of its immediate congeners, more diminutive in size, and consequently less capable of performing extensive flights, have occasionally strayed across the Channel and enlivened our glens and groves with its rich and charming song, which is far superior to that of either of the three other species of the group.

Although we cannot with propriety separate the present bird from the true Willow Wrens, still we cannot but be struck with the shorter and stouter contour of its body and its more robust bill ; it also differs considerably in its habits and mode of nidification; all those species that inhabit England constructing a singular domed nest, which is always placed on the ground, while the species here illustrated invariably builds on trees, sometimes in the shrubs of the garden, at others in the trees of forests; laying five eggs, of a reddish white blotted with spots of darker red. Those who have not had an opportunity of listening to the song of this little tenant of the grove can scarcely form an idea of its power and melody, in which respects it is only equalled by those of the Black Cap and Nightingale.

The Sylvia Hippolais appears to be dispersed throughout the European continent from Sweden to the shores of the Mediterranean.

The sexes offer no difference in the colouring of their plumage.

Its food consists of insects, such as aphides and other small kinds, to which are added caterpillars, \&c.

The whole of the upper surface is greenish ash; a small patch of yellow is situated between the bill and the eye; the throat, breast, and under surface pale yellow; wings and tail brown, the edge of each feather being lighter; feet and bill fleshy brown; irides dark brown.

The Plate represents an adult male of the natural size. 





\section{YELLOW WILLOW WREN.}

Sylvia icterina, Vieill.

La Bec-fin ictérine.

IN form and colouring this species of Willow Wren so nearly resembles the British members of this interesting group, that it requires an intimate knowledge of its habits, manners, and song to distinguish it from them with any degree of certainty. It is considered as distinct by the continental naturalists; and M. Temminck, in his 'Manuel,' informs us, that " the length of the tail, which is an inch longer than the wings, its forked form, and the comparative length of the quills and tarsi, are characters by which it may be distinguished from the two following species ( $S$. trochilus and $S . r u f a$ ); but it is always very difficult to recognise it by the examination of a single individual." To this we may add that the bill is even longer than that of S. trochilus, while the wing is quite as short, if not shorter, than that of S. rufa.

In a second remark, M. Temminck states that M. Cantraine has killed this species hopping among the reed beds in morasses of Ostia in the month of April; and that he himself has killed several in Holland, where it is less abundant than $S$. trochilus. It also inhabits France and the Roman States, frequenting the neighbourhood of water and morasses. It is probably more abundant than is generally supposed, being frequently confounded with the two species above mentioned.

Its food consists of the small insects and flies, which are attached to the branches and leaves of trees, \&c.

Of its nidification and eggs nothing is known.

Crown of the head and all the upper surface pure olive; stripe over the eye bright yellow; sides of the neck, chest, and flanks clear yellow; throat and centre of the belly yellowish white; wings and tail ashy brown bordered with greenish olive; bill and feet brown.

We have figured an adult of the natural size. 




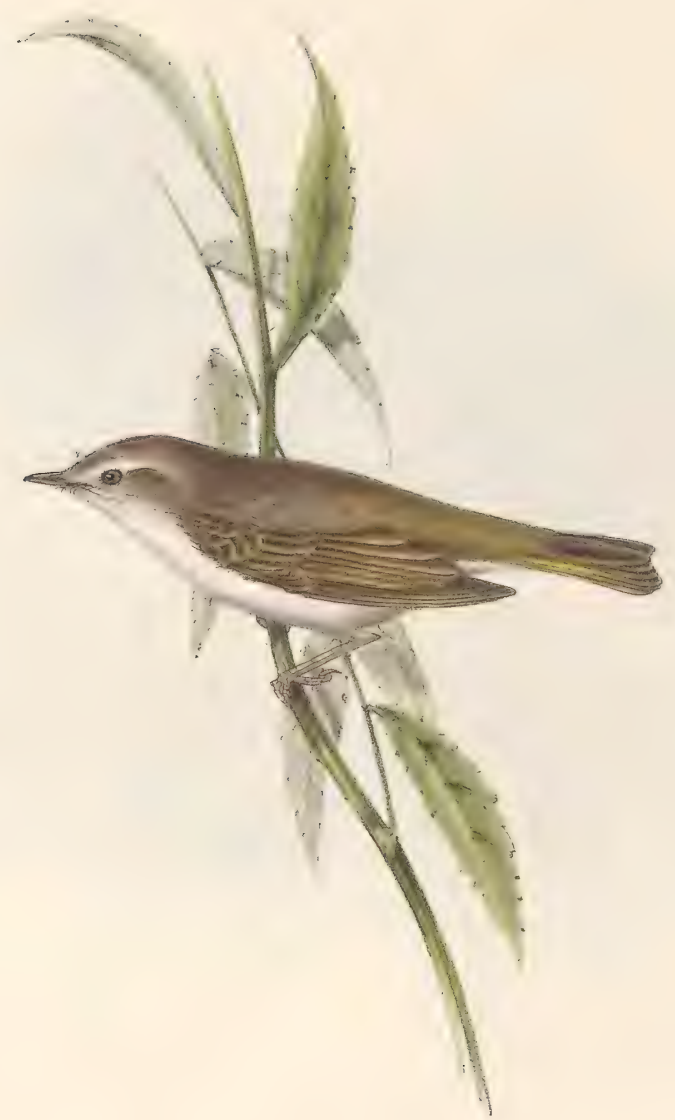

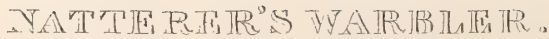

Sylvia Nattereri; (Temm) 


\section{NATTERER'S W R BLER。}

Sylvia Nattereri, Temm.

Le Bec-fin Natterer.

Turs delicate little Warbler appears to be a species of common occurrence in the district of Algesiras, in the South of Spain, where it was first discovered by M. John Natterer of Vienna, after whom it has been named. Since the period of M. Natterer's visit to Spain, about the year 1820, this indefatigable naturalist has passed sixteen years in the Brazils, whence he has lately returned to Vienna, with an exceedingly rich collection of the productions of that vast country. As a naturalist, and particularly as an ornithologist, we can speak of M. Natterer in terms of the highest praise; and it is by his discerning and ardent research during his short residence in Spain, that the Fauna of Europe has been enriched with several species which but for him would, even at this time, have been unknown to us.

The species here figured is extremely rare in all the collections of Europe : it is in every respect a true Sylvia, as the genus has been restricted by modern classifiers, and is allied in all its affinities to the Chiffchaff and Willow Wren of our own island.

Besides the locality above mentioned, M. Temminck informs us, in the third part of his Manuel, that it is common in Provence and Switzerland, that it has been killed in the Tyrol, but that it is never seen in the North of Europe.

Its food consists of flies, small spiders, and other insects.

M. Temminck also informs us that the nests found in Italy were placed on the ground among the grass, in hilly situations; were of a spherical shape formed externally of dead leaves, with a lateral opening; and that the eggs are of a globular form, four or five in number, and white minutely dotted with reddish.

The top of the head and upper surface ash brown tinged with olive; from the gape to the upper part of the eye extends a conspicuous stripe of greyish white; all the under surface silvery grey; wings and tail brownish ash fringed with olive; bill and feet brown.

The female differs only in having her tints less clear.

We have figured a male of the natural size. 



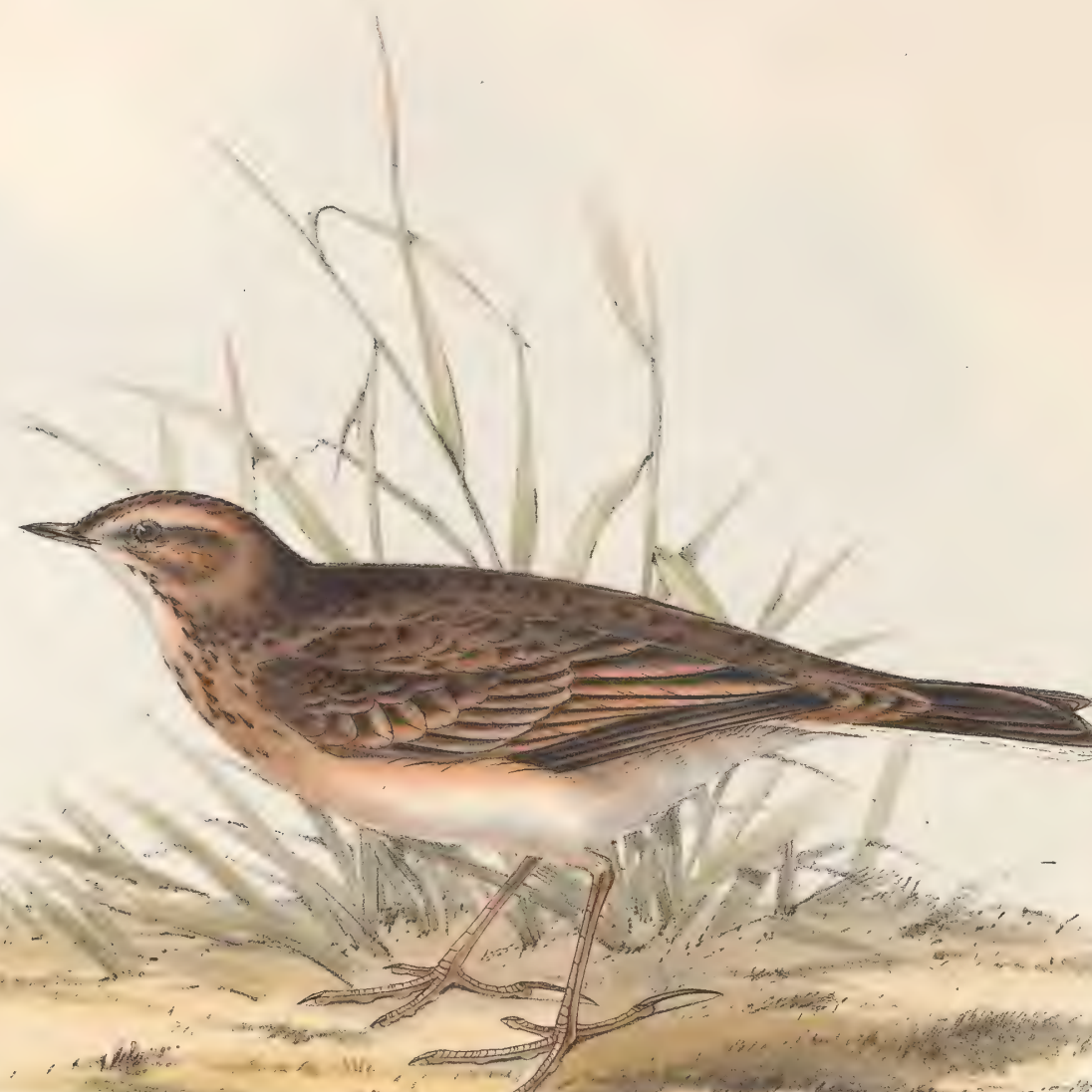

?

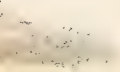

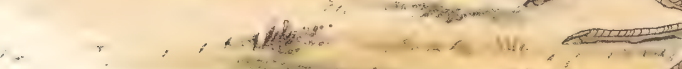
sin

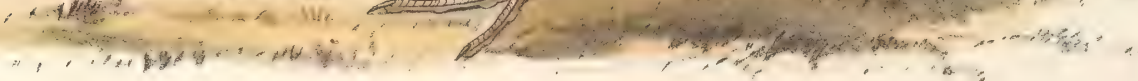

$\mathbb{R} \mathbb{I} \mathbb{C H} A \mathbb{R} \mathbb{D} \mathbb{S}^{\mathrm{S}} \mathbb{P} \mathbb{I} \mathbb{P} \mathbb{T}^{\top}$ 。

Anthus Richardi; /Viell: 


\section{Genus ANTHUS.}

Gen. Char. Bill straight, slender, rather subulated towards the point; the base of the upper mandible carinated, and the tip slightly bent downwards and emarginated; tomia of both mandibles pressed inwards about the middle. Nostrits basal, lateral, oval, partly concealed by a membrane. Tarsi generally exceeding the middle toe in length. Toes three before, and one behind; the outer toe adhering to the middle one as far as the first joint; hind claw more or less produced. Wings, the first quill very short, the second rather shorter than the third and fourth, which are of equal length, and the longest: two of the scapulars produced, and equal to the quills in length when the wing is closed.

\section{RI CHA R'S PIPIT.}

Anthus Richardi, Vieill.

Le Pipit Richard.

WE cannot but observe the near relationship which the birds of this group bear to those of the Motacillee, or Wagtails, particularly that division of them to which the illustrious Cuvier gave the subgeneric title of Budytes; to this section they offer a very close resemblance in their general contour, in the lengthened form of their hind claw, and in their habit of frequently raising and depressing the tail, accompanying it at the same time with a lateral expansion of the feathers.

Although we have no certain proof that such is the case, we have some reason to believe that the northern and western regions of Africa constitute the true habitat of the Anthus Richardi, and consequently that the individuals which make their appearance within the precincts of Europe at such irregular intervals have been driven hither by some unusual cause; at all events the small number of examples which are recorded to have been captured in Europe is a sufficient proof that this portion of the globe is not its native country. M. Temminck states that it is often met with in Picardy ; but the British Islands may, perhaps, be considered among the countries in which it has been most frequently taken, as seldom a year passes without examples falling a prey to the London birdcatchers while in pursuit of the more favourite Goldfinch and Linnet. Independently of the recorded instances of this nature, we know of two that were captured in this way during the spring of 1836, in the immediate neighbourhood of the metropolis, from one of which the present figure is taken.

In its actions the Anthus Richardi displays all the activity and alertness of the other members of the genus, among which it will rank as the largest and one of the most typical ; it never perches on trees, but is always seen on the ground, where it runs with the greatest rapidity in pursuit of its food, which consists of flies, grasshoppers, and other insects.

Of its nidification nothing is known.

The sexes are alike in plumage, and there is no difference of colouring in summer or winter.

Crown of the head and whole upper surface deep brown, each feather margined with pale brown; stripe above and below the eye pale brown, inclining to buff; throat white, surrounded by a gorget of oblong dark brown spots on a lighter ground; breast and flanks pale brown; abdomen white, slightly tinged with brown; the middle tail-feathers deep brown with paler edges, outer feather on each side almost entirely white, the next having the shaft and base very dark brown and the remainder white; bill pale brown at the base and dark brown at the tip ; legs and feet yellowish brown; tarsi long and stout; hind claw much produced and slightly curved.

We have figured a male of the natural size. 




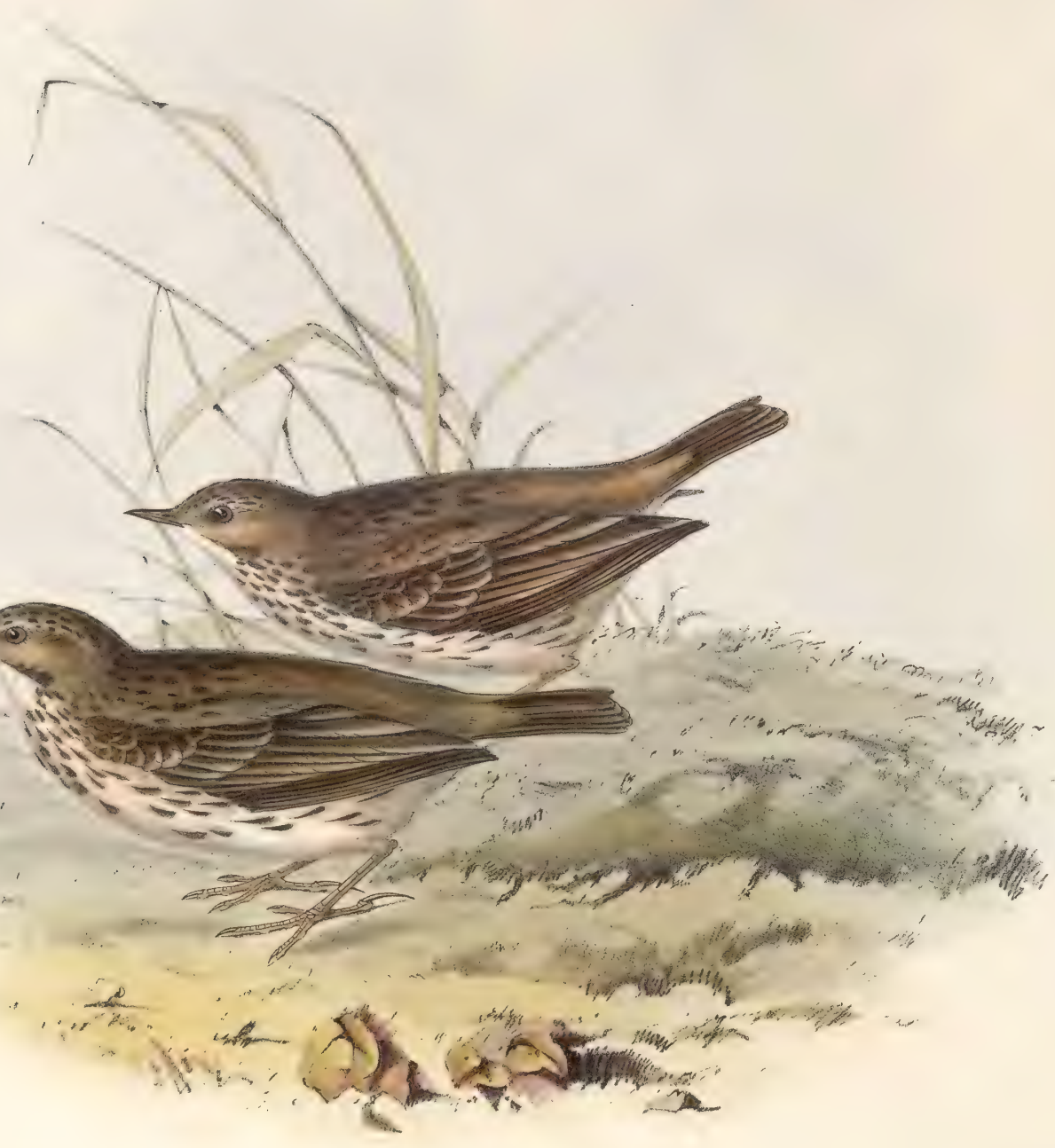

AMIEADOW PIPIT

Anthus pratensis; (Bechst:) 


\section{MEADOW PIPIT.}

Anthus pratensis, Bechst.

La Pipit Farlouse.

The Meadow Pipit is one of the smallest of its tribe, and one of the most common of our indigenous birds; it is a permanent resident in the British Islands, and is always to be found in such open situations as heaths, commons, and swampy tracts of country. Its food is always sought for on the ground, to which it is consequently restricted, and where it may be observed running nimbly along, no less lively in the depth of winter than in spring and summer. When startled from the ground it rises with a quick vibratory motion of the wings, uttering at the same time its shrill and well-known chirping cry. It is very generally distributed throughout the continent of Europe, particularly in Holland and France; it is also found in Northern Africa, and a great portion of Asia. Many authors have contended that two species, the Pipit and the Tit Lark of the older writers, have been confounded; recent observation, however, has fully proved that they are both identical with our Meadow Pipit, to which we object to apply the term Lark altogether. This erroneous impression appears to have arisen in consequence of a slight change in the colouring of the plumage at different seasons of the year; the autumnal plumage being characterized by a tint of fine greenish olive, which in the course of time gives place to a browner hue. We have ourselves had opportunities of ascertaining the correctness of Mr. Selby's observations on this point, which we take the liberty of inserting here. "In September and October, after their autumnal or general moult; they assemble in small flocks, resorting to the lower pastures, and not unfrequently to turnip fields. At this period the renewed plumage differs considerably from that laid aside, the green of the upper parts being of a much brighter tint, and the whole of the under parts more deeply tinged with yellow. In this state, the present species is to be recognised as the Pipit Lark. I have omitted no opportunity of becoming satisfied on this head, having examined specimens at all seasons of the year, and am thoroughly persuaded that the supposed species described as the Pipit Lark is in reality no more than the Common Pipit (Tit Lark of authors) in its renewed or winter plumage.

Its usual flight is by short and interrupted jerks; but in the breeding-season it differs, the bird then rising by a tremulous and rapid motion of the wings to a considerable height in the air, and commencing its song when at the greatest elevation, descending afterwards with motionless wing and expanded tail, in a sloping (sometimes almost perpendicular) direction to the earth, or to the top of some bush. It makes its nest on the ground, under the shelter of a tuft of herbage, forming it of dry grass interwoven with seed stalks of plants, and lined with finer grasses or with hair. The eggs are five or six in number, varying in colour, but the prevailing tint a pale brown, thickly covered with brownish purple red spots and specks. Like the Wagtails, it runs with celerity, and feeds upon flies, worms, and other insects." The nest of this bird frequently forms a receptacle for the egg of the Cuckoo.

The whole of the upper surface is dark olive green, the centre of each feather being brownish black ; under surface yellowish white, spotted on the sides of the neck and breast with blackish brown; flanks white, with oblong streaks of a dark colour ; tail blackish brown, the outer feather on each side having the exterior web white, and being largely tipped with the same colour, the second feather having a small white spot near the tip; bill and feet brown.

The Plate represents a male and female of the natural size. 




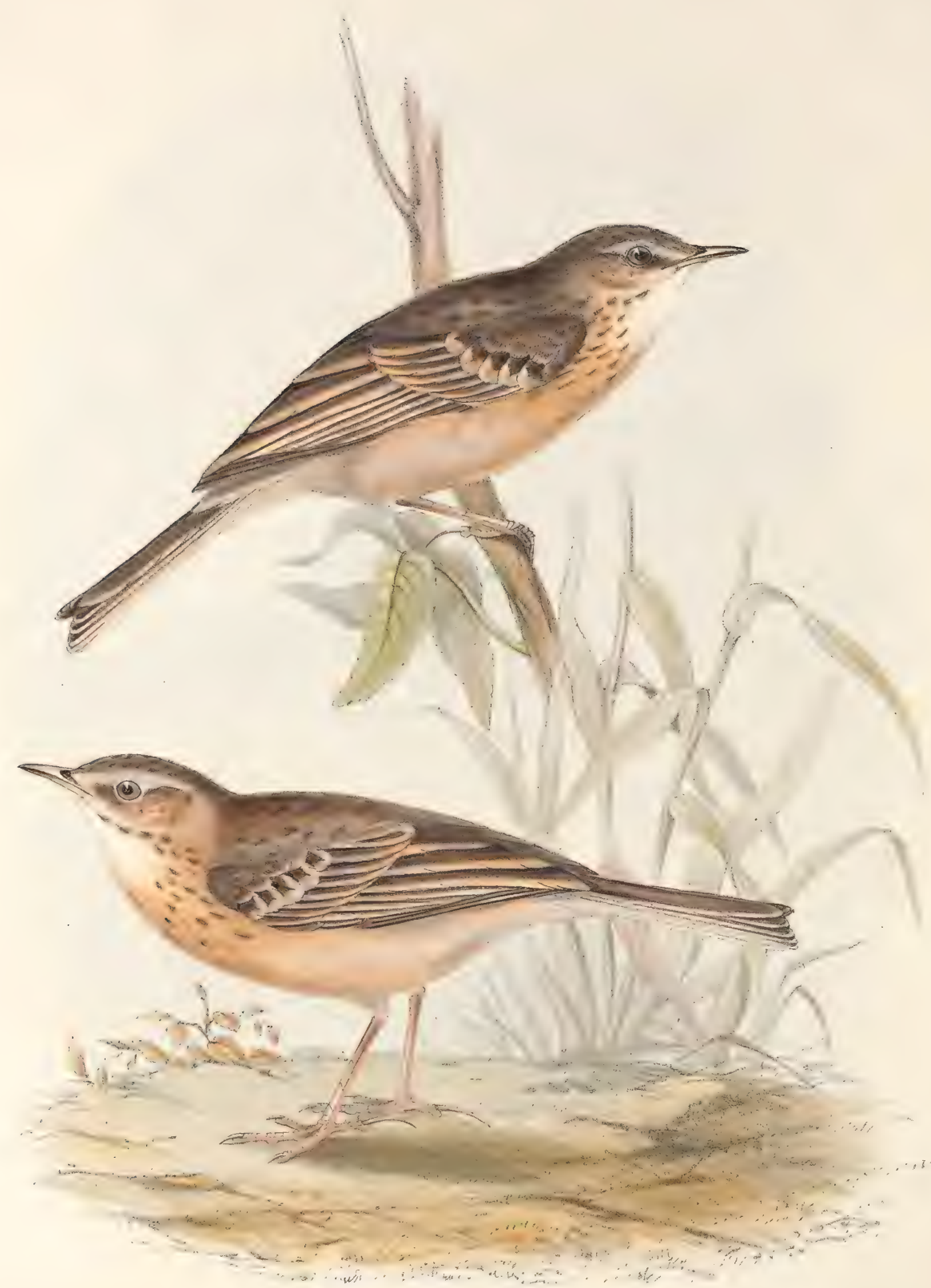

TI $\mathbb{A} \mathbb{N} \mathbb{Y}$ P II II

Anthus rufescens; (Temm: 


\section{TA W N Y PIPIT.}

Arithus rufescens, Temm.

La Pipit rousseline.

THrs elegant species of Pipit, to which M. Temminck has given the specific name of rufescens, is the same as that described by Bechstein under the name of Anthus campestris, which name M. Temminck states he has been induced to change to that of rufescens, as campestris is one of the synonyms of the Anthus pratensis, and is, moreover, a term inapplicable to either of the species.

The present is, with the exception of $A$. Richardi, the largest of the European Pipits, and may at once be distinguished by the yellow tinge pervading the whole of its plumage. It is almost strictly terrestrial, as its lengthened tarsus and hind claw clearly indicate, seldom perching upon trees: bence it is to be seen on commons, plains, and in open hilly country. M. Temminck says it is common in Germany and France, where it is migratory, visiting those countries for the purpose of incubation. It is rare in Holland, and we are not aware of any instance of its being discovered in England. We are informed that, like the rest of its genus, it constructs a nest on the ground, among herbage or loose clots of earth, laying four or six roundish eggs of a pale grey with violet and russet markings. The outward sexual differences in this species are not distinguishable, nor do the sexes offer any marked difference of plumage in the various seasons of the year.

The whole of the upper surface is of a tawny or yellowish grey, the middle of each feather having a slight dash of brown; the wings, the scapularies, and the lesser and greater wing-coverts, abruptly margined with yellowish white; throat white, as is also a large streak which passes over the eye; the whole of the under surface light Isabelle yellow; a few dusky spots commence at the lower mandible and are thinly dispersed over the chest; tail somewhat forked, the middle feathers brown, the outer ones nearly white; beak brown; legs and claws flesh colour.

The Plate represents a pair of these birds of the natural size. 




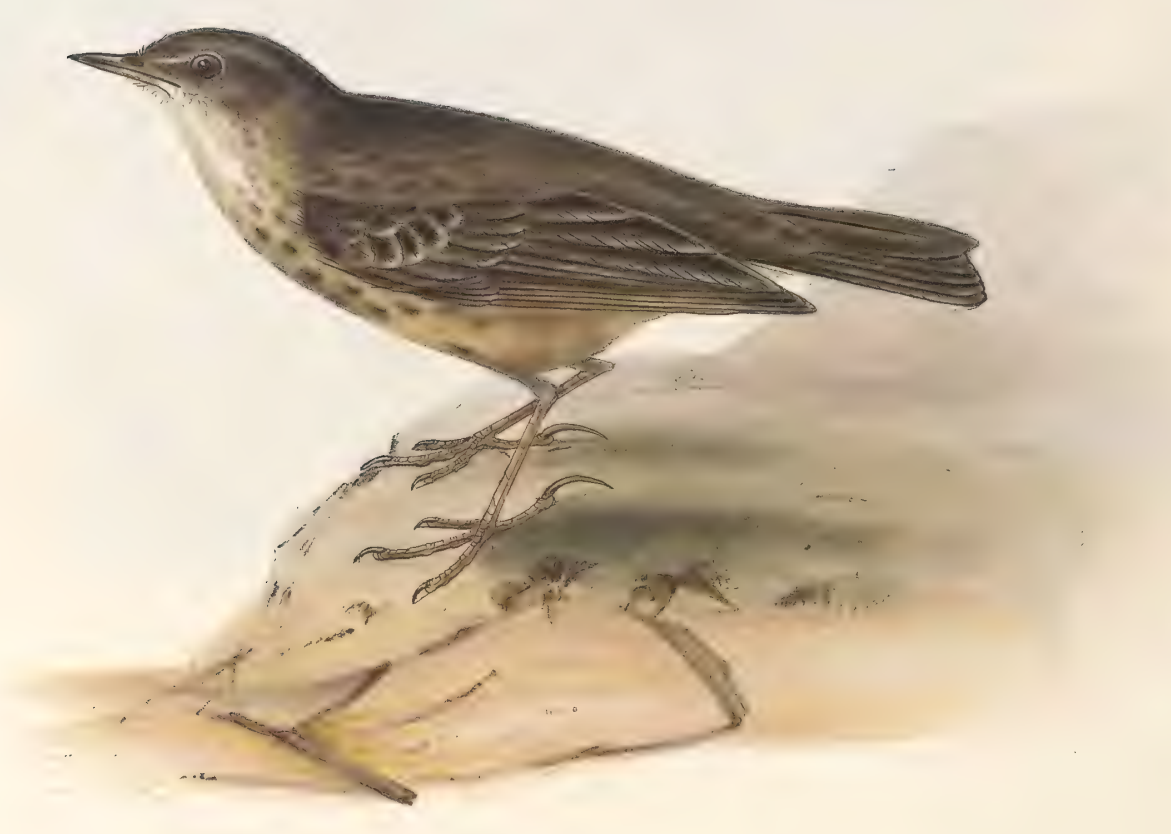

$\mathbb{R} \mathbb{C} \mathbb{K}(\mathbb{R}) \mathbb{R} \mathbb{S} \mathbb{H}\left(\mathbb{R} \mathbb{E}_{a}^{2} \mathbb{P} I P I T^{4}\right.$ 。

Anthus aquaticus; (Bechst). 


\section{ROCKOR SHORE PIPIT.}

Anthus aquaticus, Bechst.

Le Pipit spioncelle.

In the British Islands this species of Pipit is strictly stationary, inhabiting the rocky and elevated portions of the coast during summer, and the lengthened and muddy shores of the sea during autumn and winter. It rarely leaves the neighbourhood of the coast unless when following the indentations of bays or the course of large rivers, particularly those influenced by the tide. Marine insects and worms appear to constitute its sole food, in the capture of which it displays the address and agility which characterizes all the members of this group. Its call-note and song are very similar to those of the Common Pipit, from which it may be always distinguished by its larger size, and by the dusky and more obscure colouring of its plumage. It is an early breeder, and mostly selects the clefts and ledges of rocks for the site of its nest, which is composed of various marine grasses, lined with hair and fine vegetable substances; the eggs are four or five in number, of a light yellowish grey, with reddish brown specks over the larger end, and sometimes distributed over the whole surface.

We have some reason to believe that there are two species of Rock Pipits nearly allied to each other, as we have never been able to find in any of the examples killed in the British Islands that uniform vinous tint we have observed to pervade the breast of the continental examples; neither have we been able to meet with any specimens in continental collections that strictly accord with the dull and indistinct markings of those of the British Islands; to this point we would therefore beg to direct the attention of those naturalists who may possess opportunities of investigating the subject.

Crown of the head, all the upper surface, wings, and tail dark greenish olive, the feathers of the two latter margined with paler olive; throat whitish; stripe between the bill and the eye, and all the under surface pale greenish olive; the sides of the neck and breast ornamented with large spots of dark brown; the outer tailfeather on each side white; upper mandible and the tip of the lower black; the base of the latter yellowish brown; legs and feet brown.

Our figure is of the natural size. 




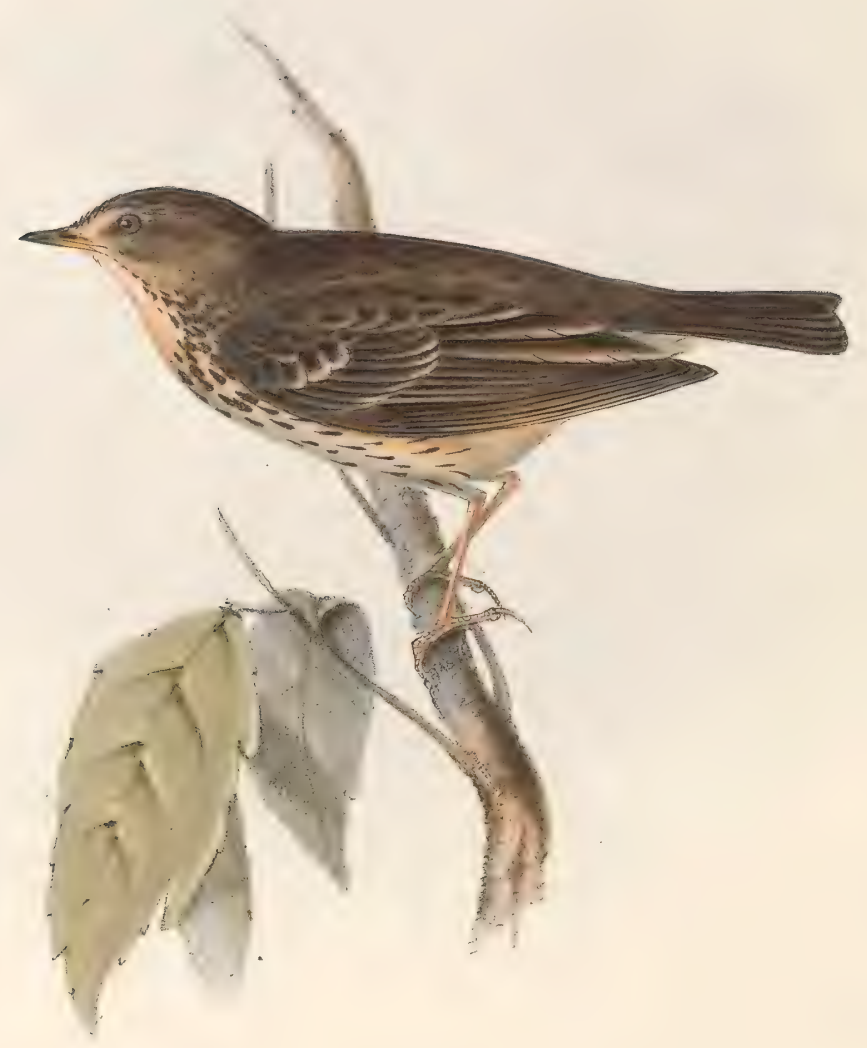

$\mathbb{P} \mathbb{R} \mathbb{E} \mathbb{E} \quad \mathbb{P} \mathbb{P} \mathbb{P} \mathbb{T}^{\mathbb{N}}$

Anthus arboreus; (Bechse) 


\title{
TRE E PIPIT。
}

\author{
Anthüs arboreus, Bechst.
}

Le Pipit des Buissons.

To a superficial observer no two birds can appear more nearly the same than the Tree and the Meadow Pipits, but on a close examination it will be perceived that a marked and permanent difference exists in the structure of the hind claw, a circumstance which, although apparently very trifling, materially influences their respective habits and manners. The hind claw of the Meadow Pipit is long, slender, and almost straight, while that of the Tree Pipit is short, and decidedly curved; hence, while one naturally frequents the ground, the other is habitually arboreal : there is also another distinction between these birds, namely, the permanent residence of one in our island and the regular migration of the other. The Tree Pipit is only a summer visitant, arriving early in spring, and forming one of the numerous songsters that render this season of the year so peculiarly delightful. It generally sings while perched upon some tree rising above the hedgerow, and is often seen to ascend on quivering wing to a moderate elevation and to descend again to the branch from which it had risen, pouring forth its animated and pleasing song as it descends. As is the case with many of our migratory songsters, the strains of this bird are most powerful and more constantly uttered on its first arrival, before the female has reached our shores, and during the season of pairing; after the work of incubation has commenced, the song is comparatively but seldom heard.

Its nest is constructed under the shelter of tufts of herbage or small bushes, and is composed of moss, fibres of roots, and withered grasses, lined with fine dry grass and horse-hair; the eggs, which are four or five in number, are of a greyish white sprinkled all over with brownish purple specks.

Its food consists of flies, small beetles and other insects, and their larvæ.

The sexes are alike in plumage, and may be thus described:

All the upper surface olive green, the feathers of the head and upper part of the back having the centre brownish black; wing-coverts margined with yellowish white, forming a double bar across the wings; chin and throat white, passing into dull buffy yellow on the sides of the chest; breast spotted with oblong marks of brown; flanks spotted with brown; middle of the belly and under tail-coverts greyish white; two middle tail-feathers pointed and of an olive brown; the exterior feather with the whole of the outer and the greater part of the inner web white; tip of the second feather also white; legs and toes yellowish brown.

We have figured an adult male of the natural size. 




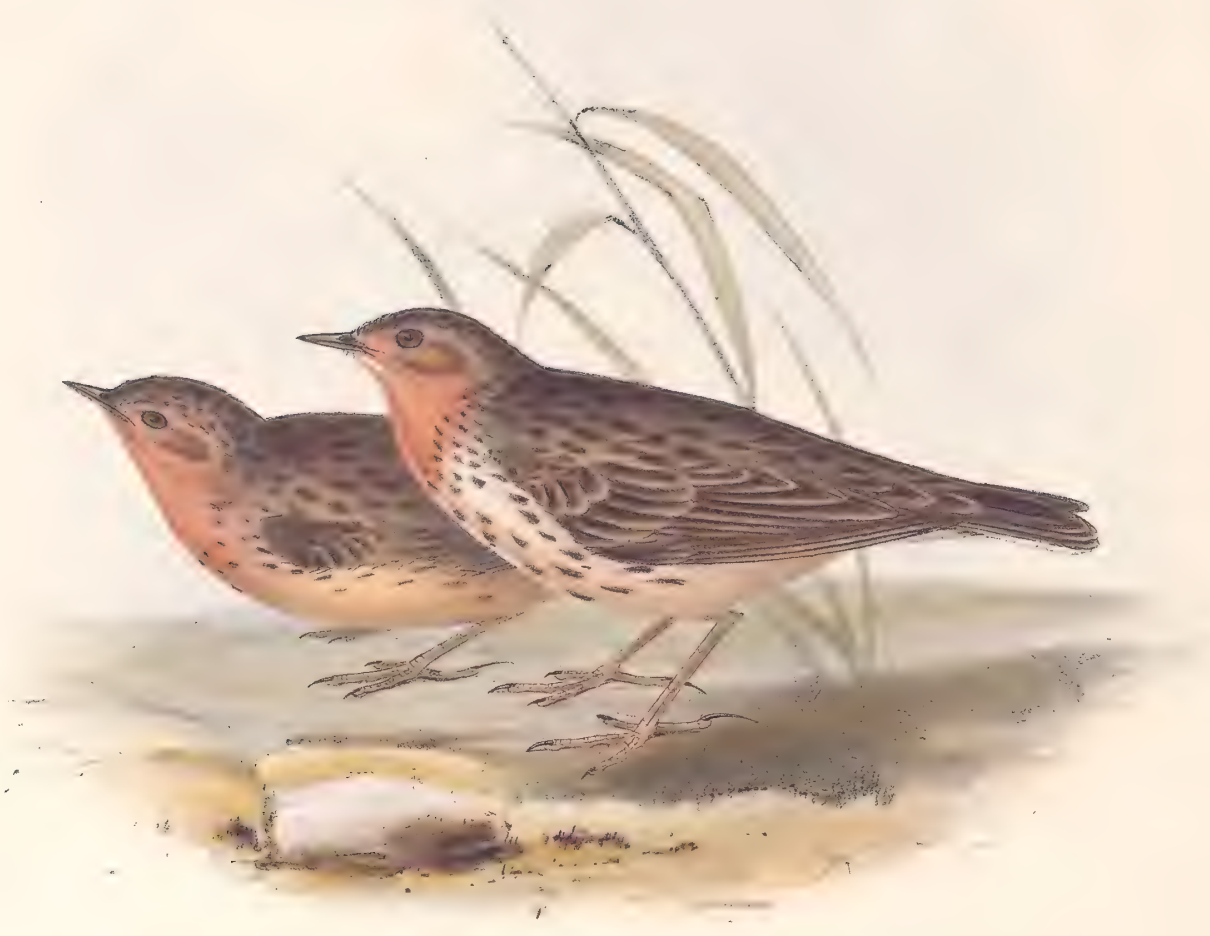

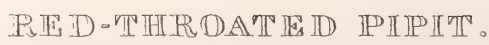

Anthus rufogularis: (Temm) 


\title{
RED-THROATED PIPTT.
}

\author{
Anthus rufogularis, Brehm \\ Le Pipit à gorge rouge.
}

Thrs very interesting species of Pipit must be considered rather as a native of India and Africa than of Europe; it has nevertheless been killed within the borders of the latter division of the globe, Sicily being, as we are informed, not unfrequently visited by it. The specimens from which our drawings are taken were sent us as Sicilian examples by M. Temminck. In size and in the general style of the colouring of the upper surface this bird exhibits a close resemblance to the Common Pipit of our island, but may be distinguished from that species and in fact from all the other known members of the group, by the rufous brown of the throat, which colour frequently proceeds over the chest and abdomen. Of the three specimens forwarded to us, one has the whole of the under surface of a rich ferruginous brown, another has the throat only of this colour, and the third has this tint so slightly pervading the under surface as to be scarcely perceptible.

In its habits, manners, and nidification this bird doubtless closely resembles its congeners, but on these points nothing has as yet been recorded.

The adult in spring has the head, and the whole of the upper surface, wings, and tail blackish brown, each feather margined with olive brown, which becomes still lighter on the extreme edge; two outer tailfeathers nearly white; a stripe over the eye, the throat, and breast rich ferruginous brown, the remainder of the under surface ferruginous buff, the lower part of the breast and flanks ornamented with oblong spots of dark blackish brown on the centre of each feather; bill and feet brown.

The female has all the upper surface similarly marked but of a much lighter tint; the stripe over the eye and the throat only, rich ferruginous brown; under tail-coverts buffy white; the remainder of the under surface pale buffy white with a conspicuous mark of blackish brown down the centre of each feather; bill and feet brown.

The young resembles the adult male, but has the light margins of the upper surface not so extensive; is destitute of the ferruginous throat; and has the breast and flanks very numerously marked with oblong spots of dark brown; bill and feet brown.

Our Plate represents male and female of the natural size. 




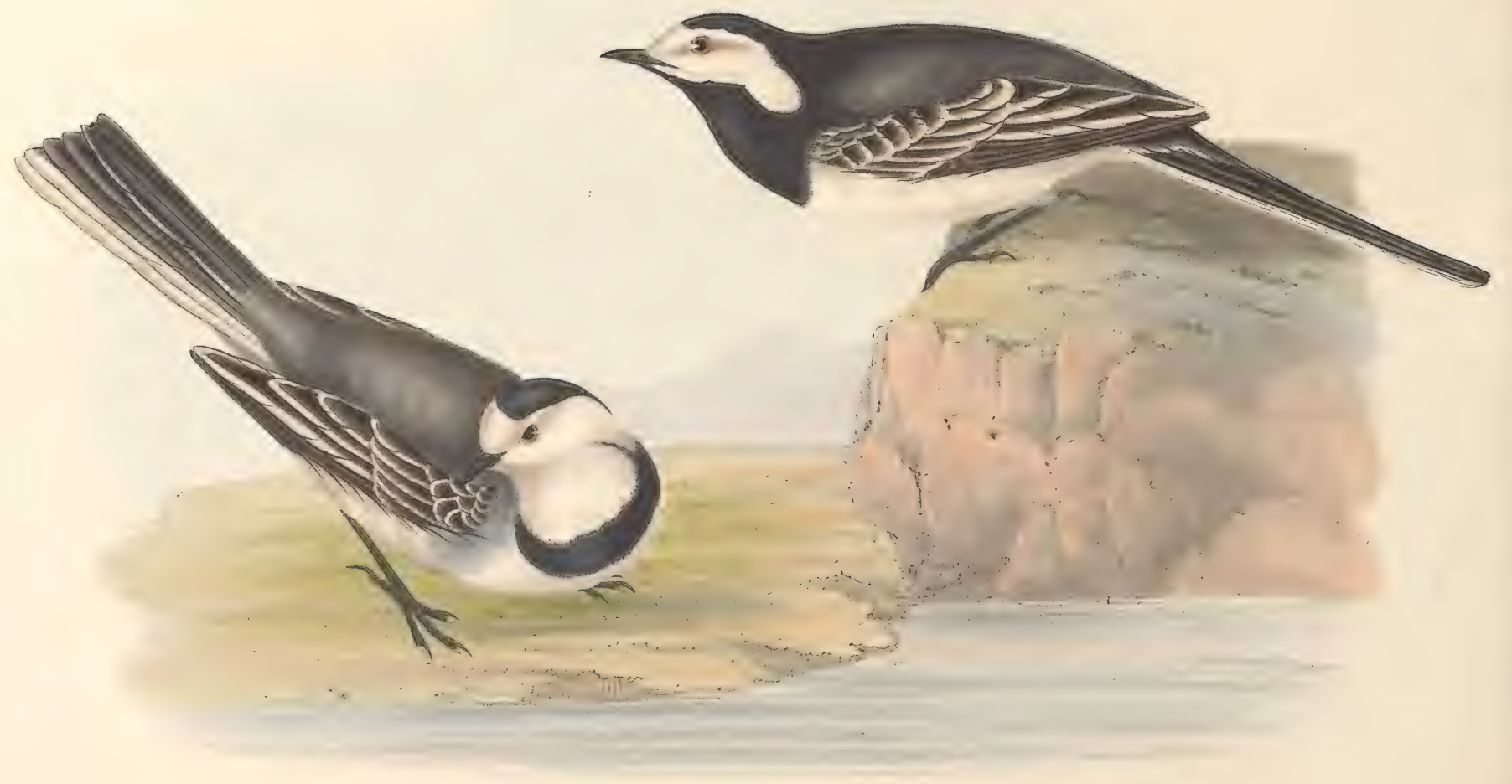

PIE D WA G T T A II 。

Motacilla alba, ( Kinn) 
Genus MOTACILLA, Auct.

Gen. Char. Beak slender, cylindric, straight; the upper mandible angulated between the nostrils, its tip laciniated. Scapulary feathers long. Hind claw shorter than the toe, nearly straight. Tarsi elevated. Tail elongated.

\title{
PIEDWA GTA IL。
}

\author{
Motacilla alba, Linn.
}

La Bergeronette grise.

THE birds supplying the subject of our present notice, though very common, are general favourites: their form is slender and elegant, their habits inoffensive, and all their varied motions so graceful and active as to insure for them our notice and regard; and the generic term applied to them, truly indicative as it is of one of their very constant actions, is most happily chosen.

The whole length of a fully grown male bird is about seven inches and a half; and in summer the upper part of the head and neck, the back, middle tail-feathers, chin, throat and breast, are black; the forehead, the space round the eyes, the cheeks, and sides of the neck white ; lower part of the breast, the belly and under tail-coverts also white; the flanks grey; wing-feathers black, with broad external edges of white forming conspicuous bars in the coverts of the quill-feathers; the two outer tail-feathers on each side white ; legs and beak black. After the breeding season, a second moult takes place; the chin and throat become white, leaving only a gorget of black; and the feathers on the upper parts of the neck and back are dark grey. In this state it remains during the winter, till the following spring bringing on a partial moult, invests it again with the plumage first described.

Young birds of the year have the crown of the head and all the upper parts ash-grey, inclining to blueish grey; wing-coverts broadly edged and tipped with white; on the upper part of the breast a crescent-shaped patch of dusky ash, the ends of which extend upwards to the ears in a narrow line on each side of the neck ; throat, cheeks, under parts of the neck and lower part of the breast, dirty white; abdomen nearly pure white ; quills blackish, with an oblong white spot on their inner web.

The old birds choose various localities in which to place their nests. It is sometimes built on the ground, or in a hole in a pollard-tree or old wall ; sometimes on a grass-grown bank; and we have found it, concealed with great care, in a depression on the side of a hay-rick. The nest is formed of moss, dried grass, roots and wool, with a lining of feathers and hair : the eggs, four or five in number, are nine lines and a half long by seven lines and a half in breadth; the ground-colour greyish white, minutely specked all over with ashbrown. The birds frequent the margins of shallow streams and ponds, and are often seen to wade a short distance to secure the larvæ and flies on which they feed. When the young are able to quit the nest, the parent birds entice them by their example over newly mown meadows, and the smooth lawns and grass-plots of pleasure-grounds. Here, secure of their footing, every motion is agile and graceful, darting and running with the rapidity of thought in pursuit of their various insect food. Their flight is undulating, performed by short jerks; and their notes, which are most frequently uttered while on wing, are far from disagreeable. With the decline of the year these birds partially desert the more inland districts, and resort in considerable numbers to the marshy margins of rivers within the influence of the tides.

The Pied Wagtail is common and stationary over the whole of the southern part of the European Continent. It also remains during winter dispersed over the southern counties of England; yet we learn from Mr. Selby and Bewick, that even so far north only as Durham, it migrates southward in October, and does not again make its appearance till the following March; and Mr. Low in his Natural History of Orkney tells us, that it continues there the shortest time of any of the migratory birds that come to build, and is never to be seen after the end of May. It is also known to migrate still further north; but, as might be expected, the higher the degree of latitude attained, the shorter is the duration of the visit.

M. Temminck, in his Manual of the Birds of Europe, includes two species of Pied Wagtails, the M. lugubris of Pallas, and the M. alba of Linneus. We have been so disappointed hitherto in our attempts to obtain both species from continental collectors, as almost to induce us to suspect their existence as distinct. All the specimens we have as yet been able to procure, prove to be referable to our own single species under some one of its various appearances; and we may add, that the last edition of the Fauna Suecica contains only M. alba.

The Wagtails, as they are usually and very appropriately termed, are common to the Old World. India supplies several species, some of which so closely resemble those inhabiting Europe, as to have been considered only as varieties, if not identical. Neither of the continents of America, however, if we recollect rightly, has as yet been ascertained to possess a single species of true Motacilla.

Our Figures represent two birds of the natural size, in the plumage of winter and summer. 




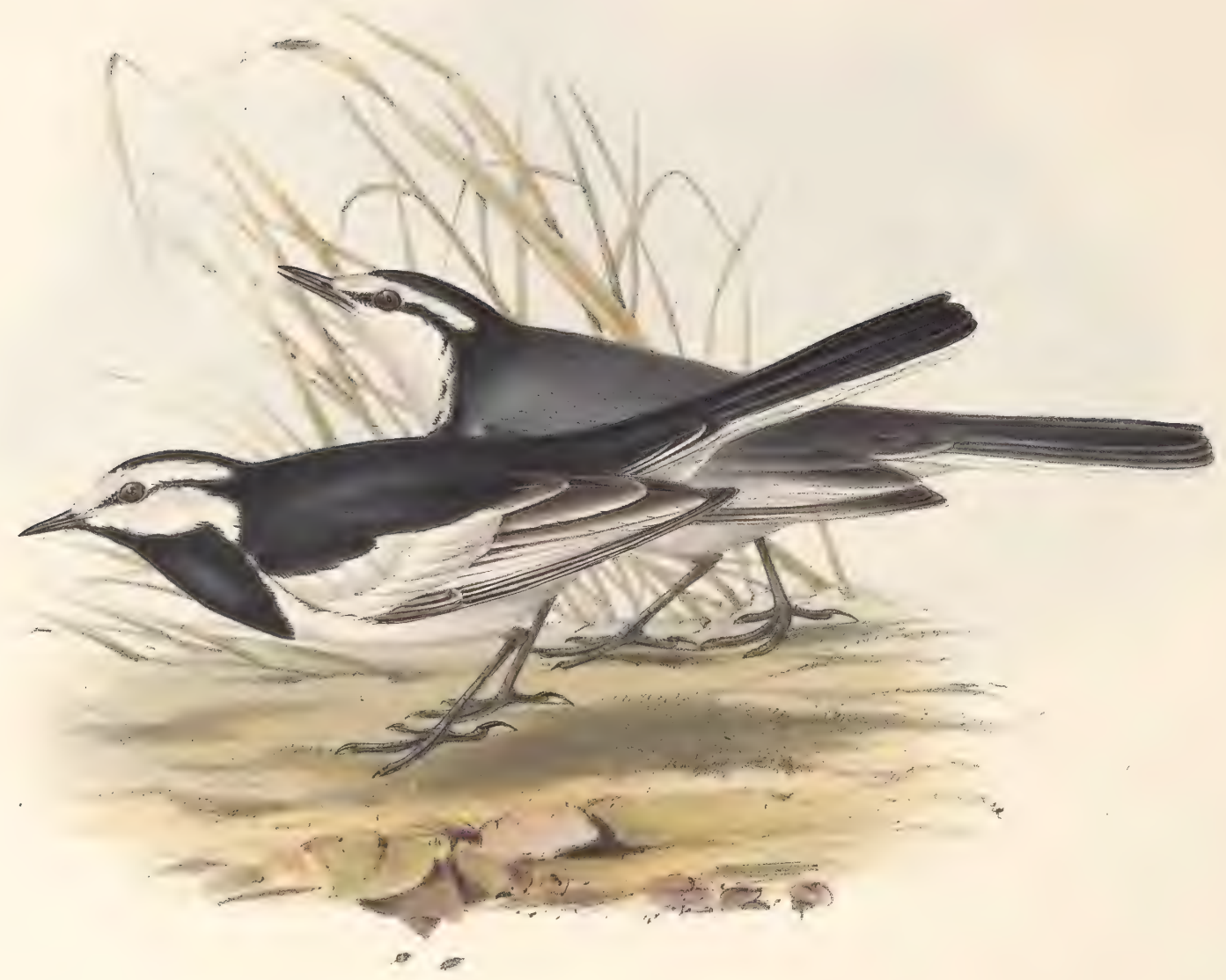

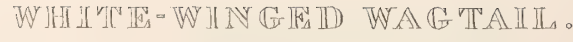

Notacilla lugubris; / Pall: 


\title{
WHITE-WINGED WA GTAII.
}

\author{
Motacilla lugubris, Pall.
}

La Bergeronnette lugubre.

$\mathrm{ON}_{\mathrm{N}}$ referring to the accompanying description of the White Wagtail, our readers will find that considerable confusion exists respecting the three species of Pied Wagtails inhabiting Europe; there cannot, however, be the slightest doubt that the present bird is very distinct from the one so commonly dispersed over the British Islands, and also from the White Wagtail, so abundant in France and the temperate portions of the continent of Europe : independently of its larger size, and the white colouring of its wings, the Motacilla lugubris may be readily distinguished from its European congeners by the conspicuous black mark between the bill and the eye. Its true habitat is also much more eastwardly than that of the other two species, being scarcely ever known to advance westward of the central parts of Europe. M. Temminck informs us that it is common in the Crimea and in many parts of Hungary, and that it is very sparingly dispersed in Italy, Provence, and Picardy. It is also found in Egypt, and in all probability in many parts of Asia Minor and the southern parts of Siberia. It is extremely common in Japan, where, according to M. Temminck, it frequents the streams of mountain valleys.

In its food and general economy, as well as in its seasonal changes, it strictly resembles the other members of the genus.

In summer, the back part of the head and neck, a line from the bill to the eye, and from the eye to the occiput, back, rump, six middle tail-feathers, throat and chest are black; the shoulders, tips and outer edges of the primaries dark greyish brown; the remainder of the wings white, with the exception of the tertiaries, which are brown in the centre; bill and feet black.

In winter the upper part of the throat is pure white; and the back and scapularies uniform grey instead of black.

We have figured two birds, one in the plumage of summer, and the other in that of winter. 




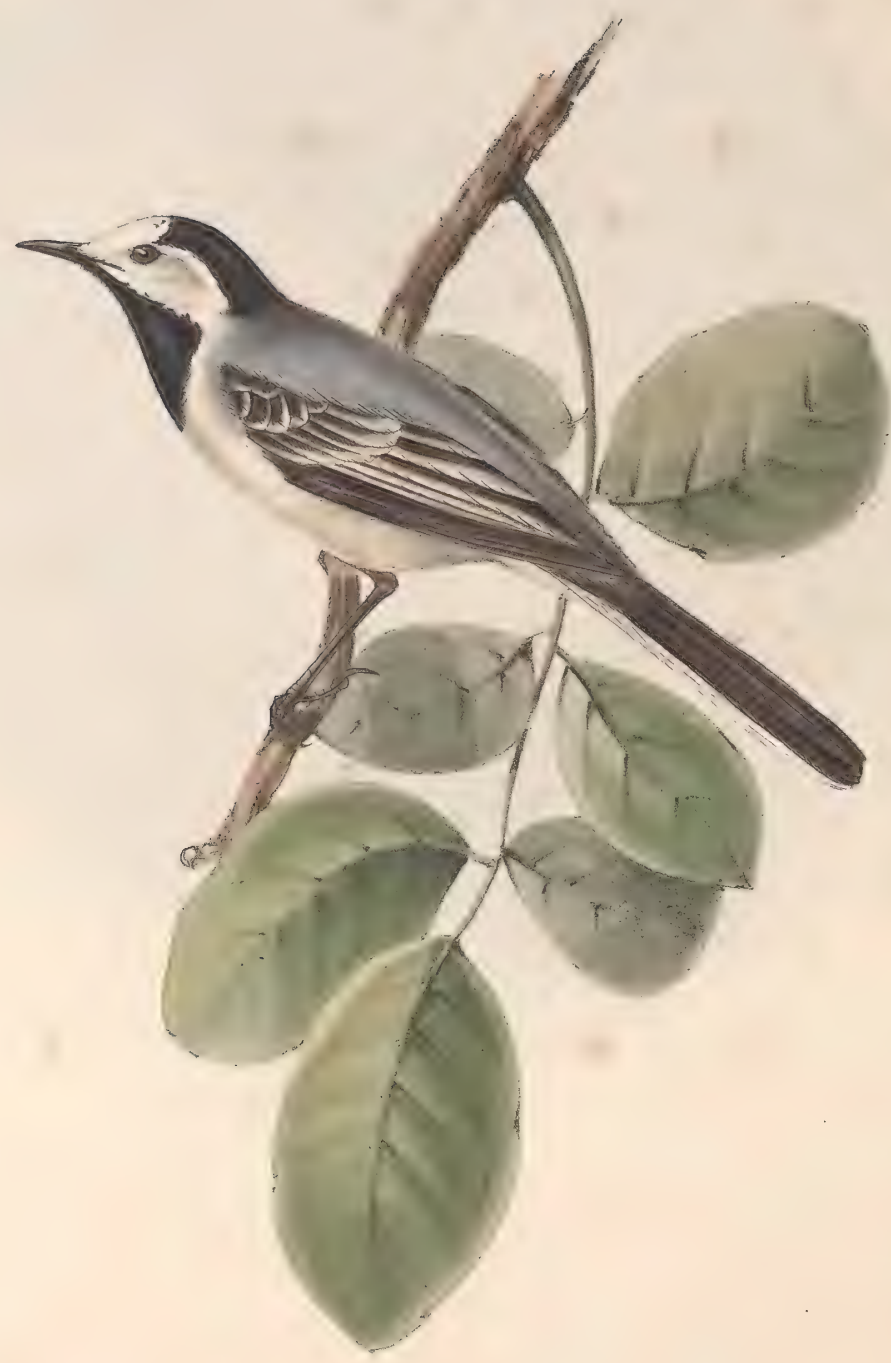

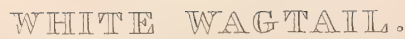

Motacilla alba: (Livnn) 


\section{WHITE WA GTAI.}

Motacilla alba, Linn.

La Bergeronette grise.

IN the early part of the present work we figured the Pied Wagtail, which is a permanent resident in our island, as the true Motacilla alba of Linnæus : subsequent experience has, however, convinced us that the true Motacilla alba, a species so common in France and Europe generally, never visits our island, and it would appear that our bird is almost equally unknown in the temperate portions of the Continent. The question therefore arises as to the species to which it must be referred: we ourselves are inclined to believe it quite distinct from Motacilla lugubris, a species inhabiting the eastern and southern portions of the Continent, and with which it has by some naturalists been considered as identical ; should this ultimately prove to be the case, the English bird will require to be characterized under a new specific appellation. The Channel appears in fact to constitute the boundary of these species, as is also the case with Motacilla neglecta and Motacilla flava.

The true Motacilla alba differs from our species more in its colouring than in any other respect : neither in its full nuptial dress nor at any other period does it exhibit the deep black colouring on the back which is so conspicuous in the British species; at least after the examination of a great number of specimens, we have never been able to trace the slightest indication of it at any age.

The White Wagtail frequents meadows, particularly those in the neighbourhood of running streams, also villages, cities, belfries, towers, and similar situations. It is a common species in Africa and the high lands of India.

Its food consists of flies, millipedes, various other insects, and their larvæ.

The nest is placed in any convenient situation that may offer; in the clefts of rocks, under the arches of bridges, in towers, or among hollow trees; the eggs are six in number, and are of a bluish white, spotted with black.

In spring the forehead, sides of the neck, under surface, and the two outer tail-feathers, are pure white; occiput, nape, throat, chest, middle tail-feathers, and upper tail-coverts, black; back and sides pure ash colour; wing-coverts blackish brown bordered with white.

The female differs in having the white less clear, and the black mark on the occiput not so extensive.

In winter the throat and front of the neck are pure white; on the lower part of the neck a collar of deep black; all the ash of the upper parts less clear than in summer.

We have figured an adult male of the natural size. 




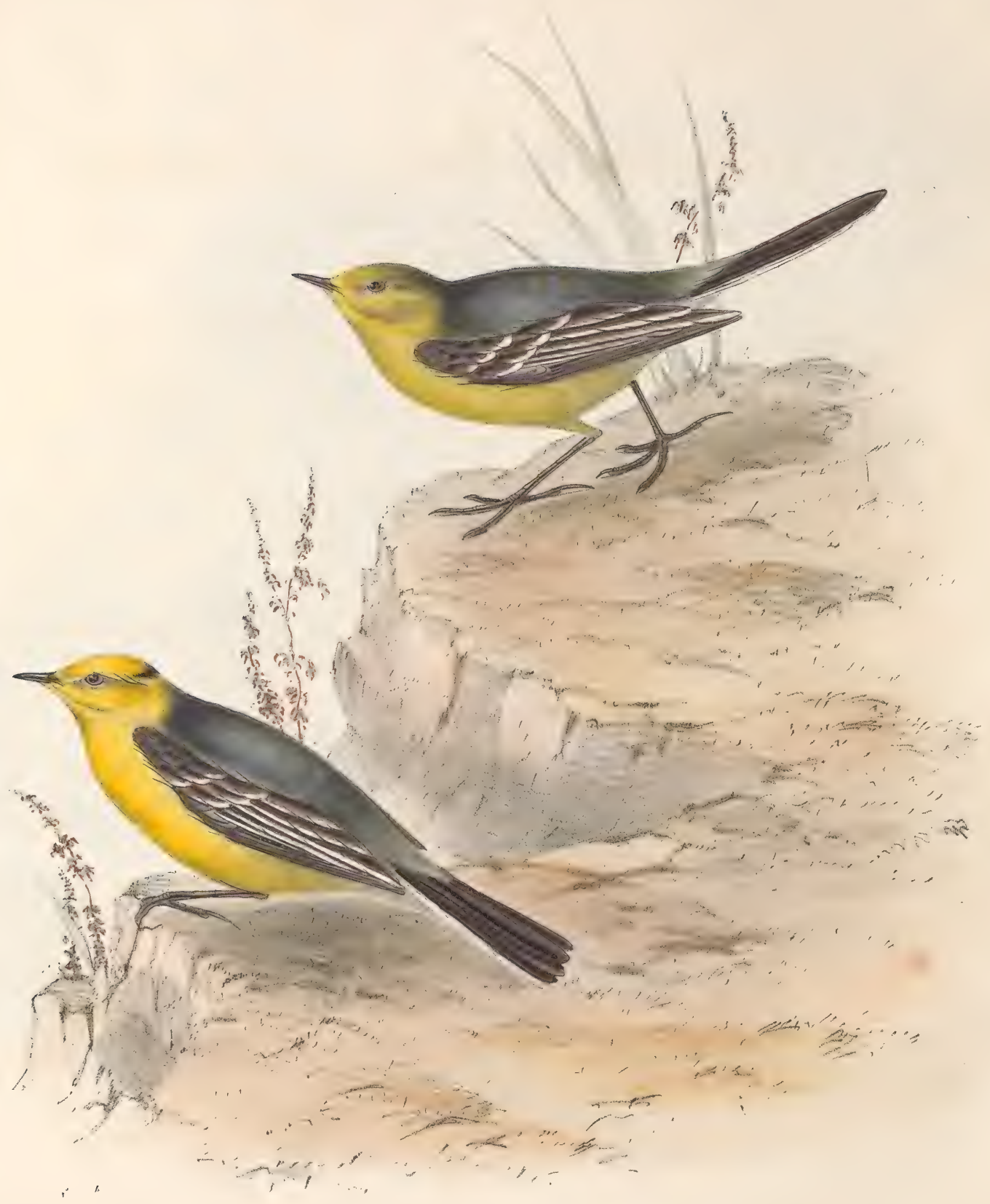

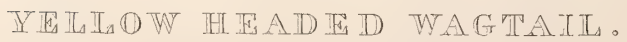

Notacilla citreola: ' Pall., 


\title{
YELLOW - HEA DEDW A GTAIL.
}

\author{
Motacilla citreola, Pall. \\ La Bergeronette citrine.
}

A paIr of this very rare and beautiful species of Wagtail has been very obligingly lent to us for this Work by Lieut. Col. W. H. Sykes, whose rich collection of birds from the Dukhun has at all times been open to our inspection, and has afforded us opportunities of ascertaining the fact, that many of our rare European birds, which more exclusively belong to the eastern portions of that continent, are in reality natives of the western countries of Asia, whence, it would appear, they occasionally migrate to the adjoining districts of Europe, so as to form a connecting link uniting the productions of Europe to those of Asia; and this appears to be the case with the bird before us, whose rare and uncertain visits, according to M. Temminck, to Oriental Russia and the Crimea have afforded little opportunity of ascertaining either its habits or the circumstances connected with its nidification; but we may reasonably expect, from its close affinity in appearance to our well-known Yellow Wagtail (Motacilla fava, Ray,), its habits and manners, as well as its mode of nidification, that it is somewhat similar. In the Proceedings of the Committee of Science and Correspondence of the Zoological Society of London, Lieut. Col. Sykes briefly mentions, that this bird has the habits, manners, aspect and size of Budytes melanocephala, and, like it, is solitary and only found in the vicinity of rivers; but Colonel Sykes did not see the two species together. Larvæ of water insects and greenish mud were found in the stomach. Colonel Sykes expresses his belief, that this species together with the Budytes melanocephala and Budytes Beema, all possessing the long hind claw, do not habitually perch, but like other birds with a similar claw, as in the genera Anthus, Alauda, Mirafra, and Fringilla crucigera, Temm., nocturnate on the ground. We regret that neither our own observations, nor the numerous works to which we have access, will enable us to add much to this short notice; we may state, however, that we coincide with the views of M. Temminck in considering that Hungary and the Archipelago may also be occasionally visited by it.

In size the Motacilla citreola is somewhat inferior both to M. Alava and neglecta, from both of which it may readily be distinguished, in its spring plumage, by the fine citron yellow which covers the top of the head, the cheeks, and the whole of the under surface. A crescent-shaped band of black crosses the occiput, and dark ash colour slightly tinged with grey pervades the upper plumage; the middle and the greater coverts of the wings are edged with white; the tail-feathers black, with the exception of the two outer ones on each side, which are white.

The males and females in winter, says M. Temminck, have not the black occipital band, that part being then yellow like the rest of the head.

Our Plate represents a male and female, proved to be such by dissection, in their summer plumage; the lower bird in the Plate being the male. 




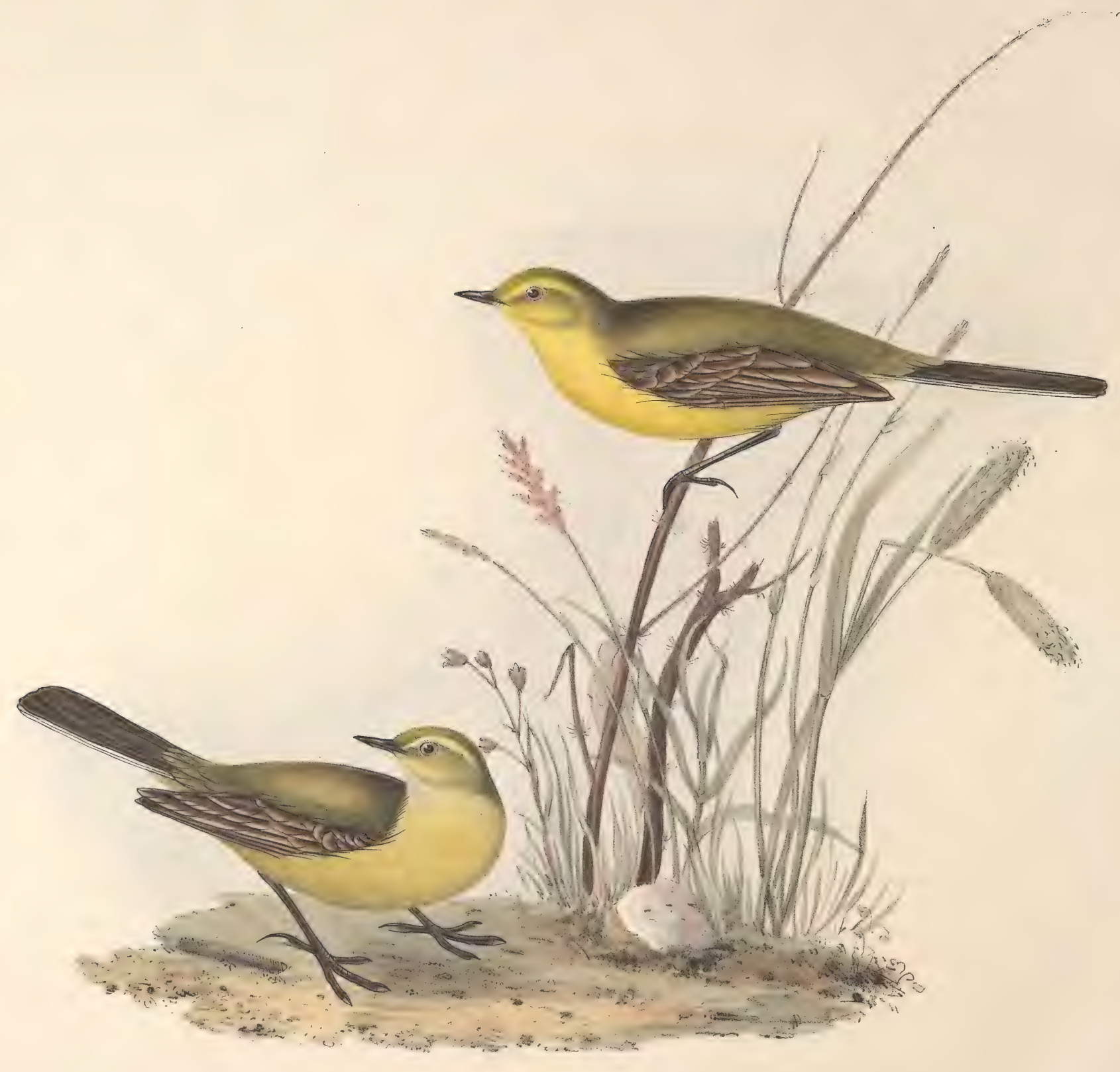

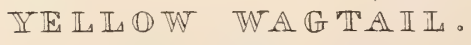

Motacilla llava; (Ray). 


\title{
YELIOWW W G TIL.
}

\author{
Motacilla flava, Ray. \\ Budytes flava, Cuv.
}

THE present species as well as that we have denominated Motacilla neglecta have been separated by M. Cuvier from the Motacilla of authors, and formed into a new genus under the name of Budytes, in consequence of its lengthened hind claw indicating an approach to the genus Anthus, or Pipits. Although we see the force of M. Cuvier's views, still we feel rather inclined in this instance to adhere to the old arrangement, as the general habits and manners of the Wagtails are so much alike; at the same time a direct union may be discovered between the pied species and those of more gaudy plumage, both as regards the style of colouring and structure, as in the Motacilla boarula, that bird having the fine yellow plumage so characteristic of Cuvier's subdivision, together with the elongated contour of body and shortened hind claw which distinguish those to which M. Cuvier would exclusively apply the term Motacilla. It must, however, be allowed that the birds in question form the extreme limits of one genus, and indicate where another commences; still we think grounds like these scarcely warrant the formation of new genera, otherwise they would indeed become multitudinous. We have, nevertheless, not felt ourselves at liberty to omit the notice of the genus Budytes, established as it is by so eminent a naturalist as Cuvier, whose clear and comprehensive views cannot be too highly appreciated; but having stated our opinion, will leave it to the intelligent reader to decide for himself, whether to retain the old term Motacilla, or adopt the more recent title as a generic appellation.

This delicate and showy bird visits us early in spring, frequenting open plains and meadows, particularly fields of rising wheat, pastures for cattle, and arable lands. It is a bird sufficiently familiar to allow of close approach, and may be observed full of life and vivacity, running nimbly over the turf, catching flies and other insects, which constitute its food. Hence it is often found near flocks of sheep and herds of cattle, whence its French name Bergeronnette. It continues with us during the summer, and leaves us again early in autumn, the adults invariably leading the way, and are followed by the young at a subsequent period. Its note is rather shrill, but resembles that of the other birds of the genus. It breeds on the ground, constructing a nest of loose fibres and dried grasses lined with hair. The eggs are four or five in number, of a yellowish white colour mottled with darker yellow brown. We have every reason to believe that the present species is equally common throughout the western portions of Europe, but has been overlooked or confounded with the bird we have denominated Motacilla neglecta.

In the adult male, the bill is black; irides hazel; the whole of the head and back of the neck pale olive green, over the eye a streak of pure yellow; back, scapulars, rump and tail-coverts rather darker than the colour of the head; quill-feathers dusky, edged with yellowish white tail dusky, the two middle feathers tinged with olive, and the two outer feathers on each side having their external webs almost entirely white; legs black, hind claw long; the whole of the under parts bright yellow.

The female differs in having the plumage less brilliant, the yellow of the under parts being much paler.

We have figured a male and female of the natural size. 




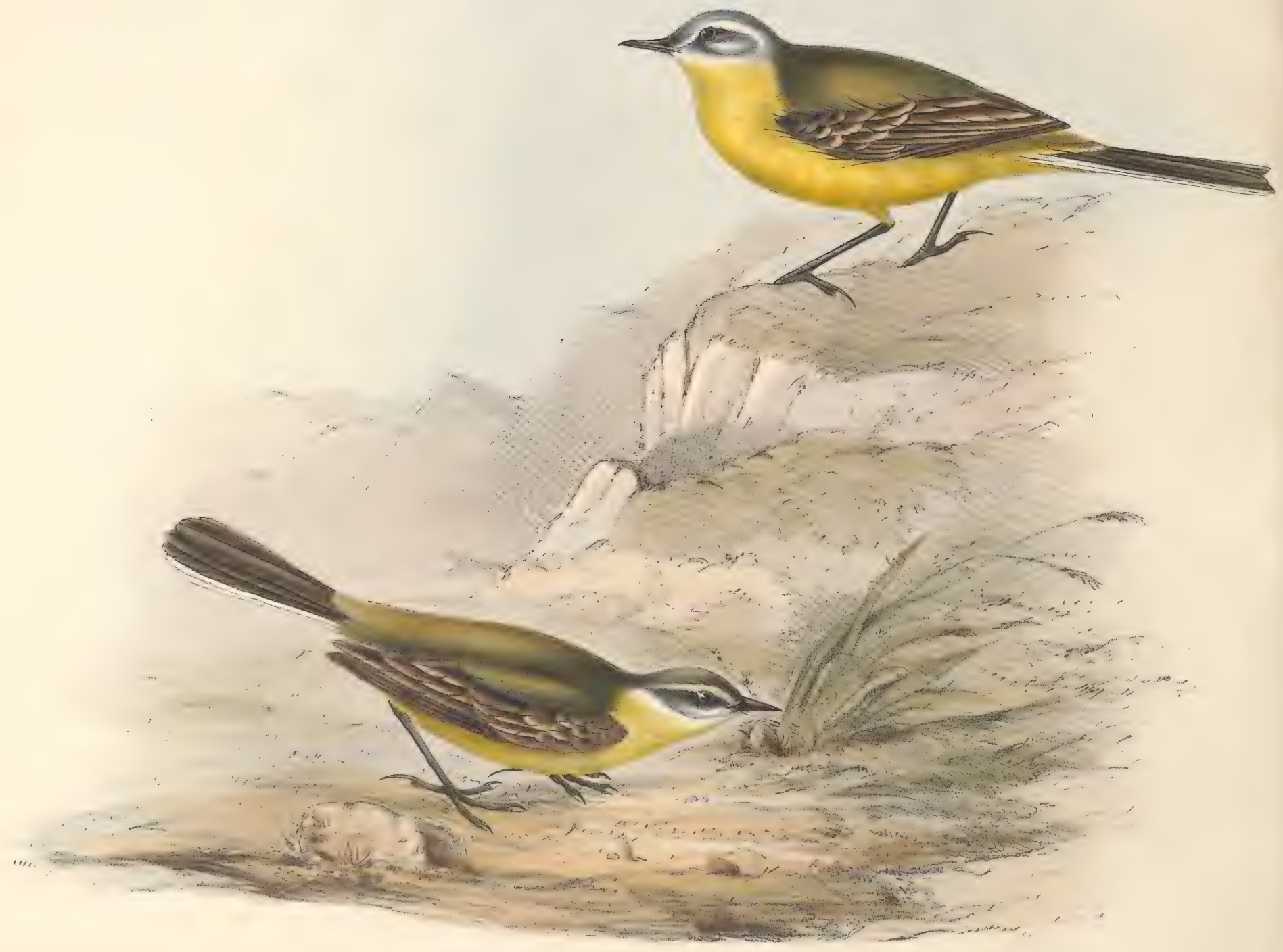

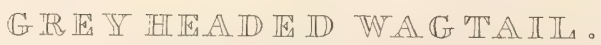

Motacilla neglecta; (Gould). 


\title{
GREY-HEADEDWA GTAIL。
}

\author{
Motacilla neglecta, Gould. \\ Budytes neglecta, Cuv.
}

Having received this bird in considerable abundance from the Continent at the same period of the year in which the Yellow Wagtail visits England, we were struck with the difference between the two; we therefore diligently examined the works of Buffon, Linnæus, and Temminck, and found that each of these authors accurately describes the present bird under the name of Motacilla flava; but upon turning to the work of our English naturalist Ray, we found that his description of the Yellow Wagtail truly agreed with our species, and that the Continental authors had in their works applied his name to the bird now in question, a species possessing totally different characters, and with which Ray does not appear to have been acquainted. Our intention, therefore, in figuring the present bird under the new name of Motacilla neglecta, is to secure to the Yellow Wagtail the name originally applied to it by our distinguished countryman ; recognising in the bird here figured a species distinct from the Yellow Wagtail, with which it has hitherto been confounded. To prevent any suspicion that the two birds are merely varieties, we took the trouble of procuring from various parts of the Continent, examples, both male and female, of Motacilla neglecta, a species not found in England, which we compared with both sexes of our British $M$. fava, and had the pleasure of placing several examples of both sorts on the table before the Meeting of the Committee of Science and Correspondence of the Zoological Society of London, on the 12th of July 1832; and in the printed Report of Proceedings, our opinions were first recorded. Although not visiting England, we presume the $M$. neglecta to be extensively spread over the Continent: we have received it in a recent state, shot in the neighbourhood of Paris. On the 28th of May last, males and females were killed by N. C. Strickland, Esq., in Sweden, who kindly favoured us with the loan of his specimens. From the account of this gentleman, their manners are very different from those of our Yellow Wagtail, running about with the tail elevated and the wings hanging down and spread; and so singular was their appearance that he was induced to make a drawing of the birds in this attitude, which he has kindly submitted to our inspection. We have also received this bird from the Himalaya Mountains. As our acquaintance with this species is extremely limited, although on the Continent it is so well known, we avail ourselves of the account of this bird in the work of M. Temminck, where it will be found described under the name of $M$. Alava.

This eminent naturalist informs us that it inhabits meadows and the banks of small streams, and is found generally in the northern and central parts of Europe.

The head and back of the neck are of a pure blueish ash-colour; the rest of the upper parts are of an olive green; a white line extends from the beak above the eyes, and another from the lower mandible passes below the orifice of the ears; the lower parts are of a bright yellow; the quills and middle tail-feathers blackish, edged with yellowish white, the two outer tail-feathers white; the tail slightly rounded and extending beyond the wings only an inch and nine lines; the posterior claw long and arched. Length of the bird six inches.

The female has the upper surface more clouded with ash-colour, the under surface less lively, and the throat is yellowish white.

The young, with considerable resemblance to the female, are of a dull ash-colour above, and yellowish white below; the breast is sometimes blotched or waved with brown.

Flies and aquatic insects form their principal food ; their nest is built in holes in the ground in meadows, or at the roots of trees ; the eggs are six in number, of a greenish olive, with light flesh-coloured blotches.

We have figured a male and female in their adult plumage, of the natural size. 




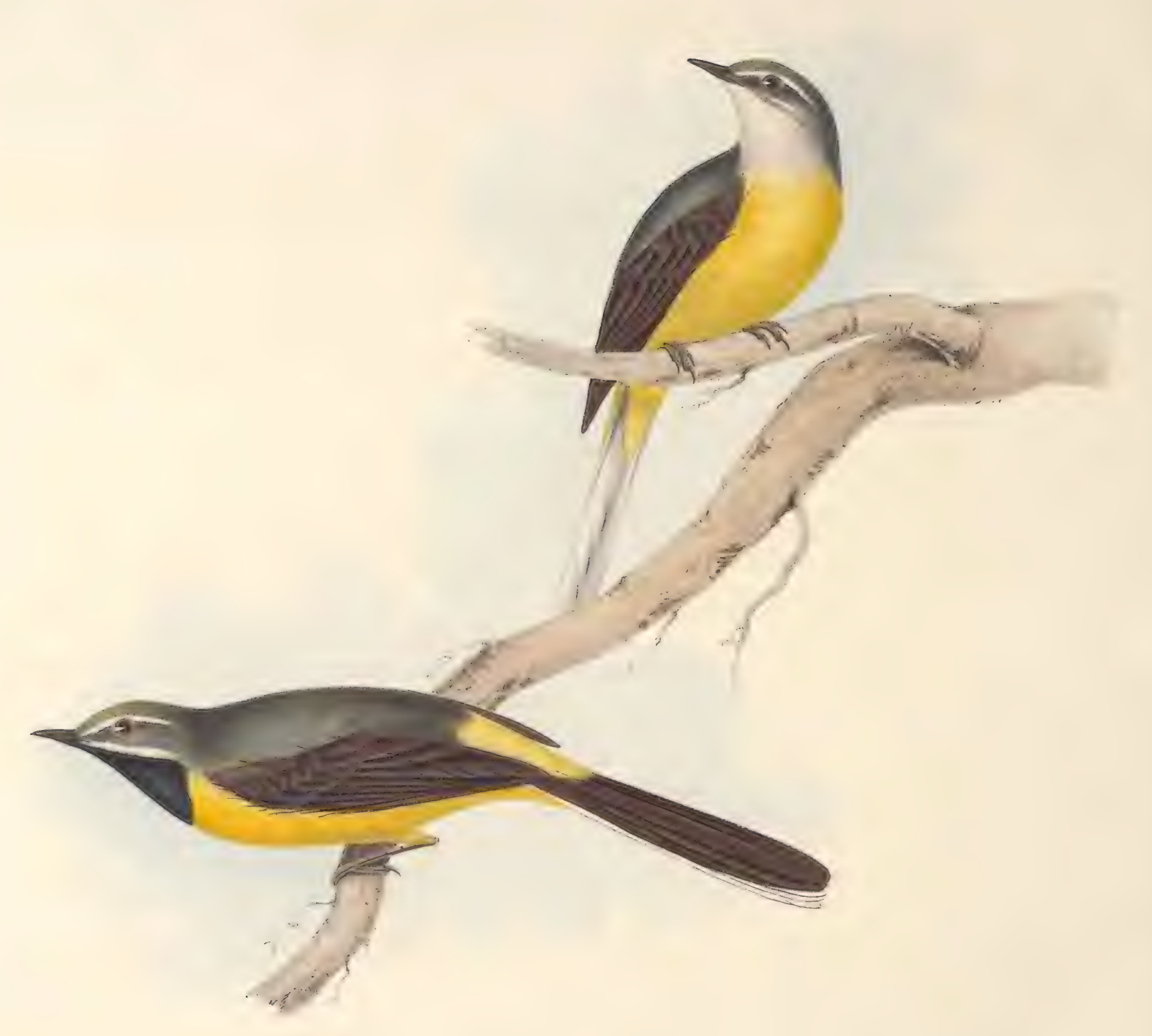




\title{
GRE Y WA GTAIL。
}

\author{
Motacilla Boarula, Lath \\ La Bergeronnette jaune.
}

THrs elegant and graceful species is indigenous in Great Britain, but performs periodical migrations within the limits of our island, visiting the southern counties during the winter, and returning northwards to its breeding places as the spring advances, when it is by no means uncommon in Scotland and the border counties.

In habits and manners the Wagtails have all a general similarity; but the present species may be especially distinguished by its finer contour, the superior sprightliness of its air, and the activity of its movements; not only running nimbly and rapidly along the ground, but perching also on trees. More solitary than its congeners, it seldom congregates, but is found dispersed in pairs along the edges of limpid streams, frequenting more rarely the dry and open pastures.

According to Mr. Selby, it arrives at its northern breeding places in April, where, on a stony bank or shelf of rock forming the margin of a stream, it constructs a nest of moss and dried grasses lined with hair ; the female laying six eggs, of a yellowish grey blotched with darker shades of the same colour, and usually producing two broods in the year. The process of incubation and rearing its young being over, it retires in September, or the beginning of the following month, the parent birds and their young migrating together.

The present species is extensively spread throughout the northern portions of the European Continent, and we have received it also from the highlands of India.

The grey Wagtail, like the more typical of its family, exhibits considerable variety in its summer and winter plumage, a circumstance which we have endeavoured to elucidate in the annexed Plate, from which it will be seen that during the breeding season and summer months the plumage is not only generally brighter, but that the throat becomes black in both sexes, although in the female the hue is not so deep. It would seem that another moult takes place in autumn, after which the black of the throat entirely disappears, and a yellow tinge assumes its place, from which fact the present species has been occasionally confounded with the yellow Wagtail ; it may, however, at once be distinguished by its more slender and symmetrical form of body, the grey colour of the back, and the bright sulphur hue of the rump. Above the eye there is a streak of white, and another below ; this last the least conspicuous. The under parts are bright gamboge-yellow; wings dark grey, coverts tipped with white; middle tail-feathers black; outer one on each side white; the next white on its external edge: total length eight inches, of which the tail measures four.

Its food consists of insects, especially aquatic varieties, and their larvæ, in pursuit of which it may be frequently observed wading fearlessly in the shallow parts of the stream, displaying grace and agility in every action.

Our Plate gives the male in his summer and winter dress; but little differences exist in the plumage of the sexes. 




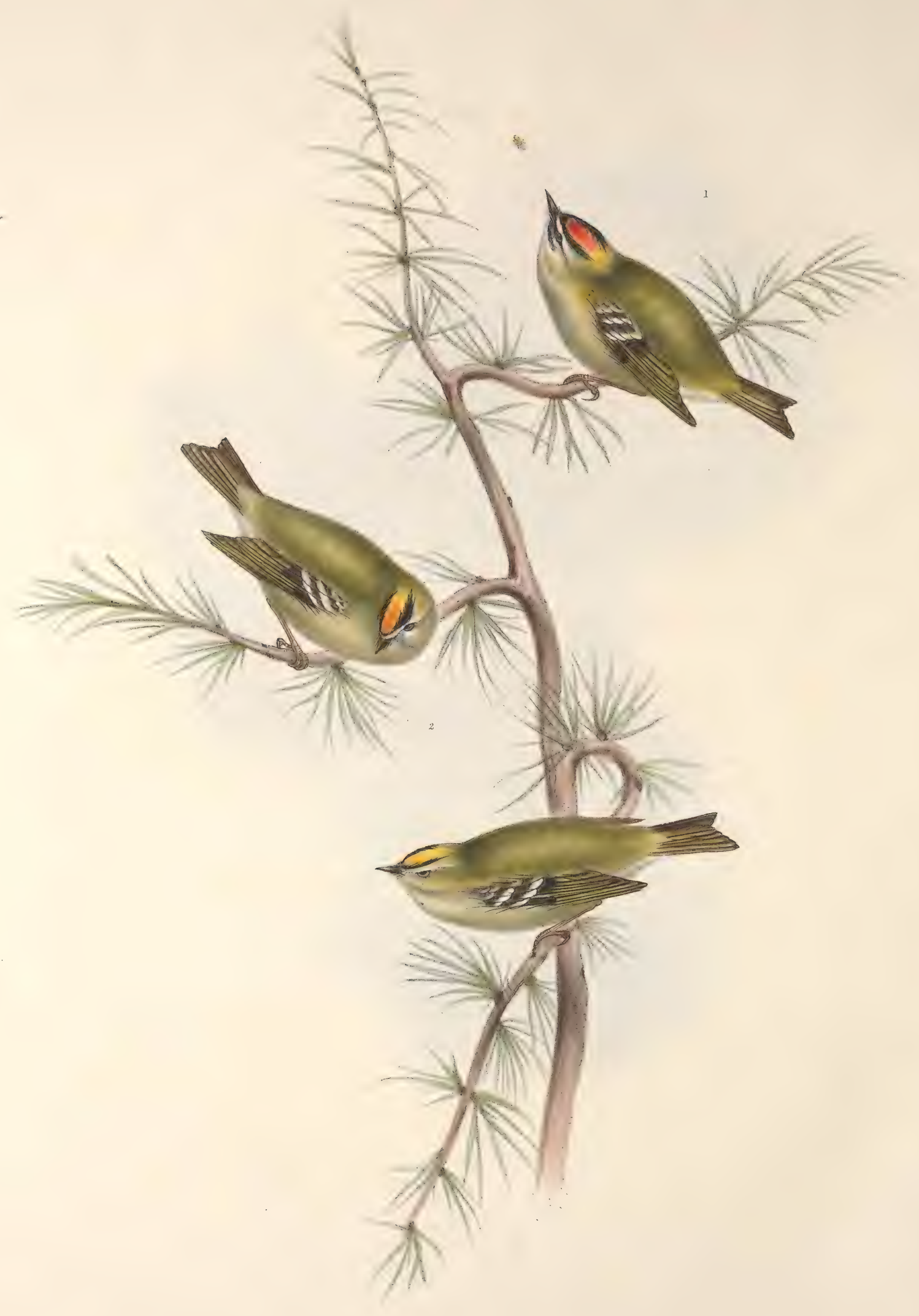

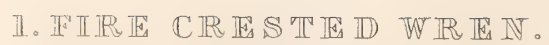
Reǵulus iǵnicapillus; (Brehm).

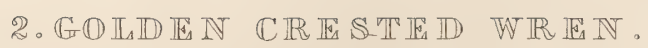
Regulus vulgaris; (Cuvv) 


\title{
Genus REGULUS, Cuv.
}

GEN. Char. Beak very slender, short, straight, slightly compressed laterally; the upper mandible slightly laciniated towards the tip. Nostrils covered with two recumbent feathers. Wings rounded. Tarsus longer than the middle toe.

\section{FIRE-CRESTED WREN.}

\author{
Regulus ignicapillus, Briss.
}

Le Roitelet à triple bandeau.

THE beautiful little birds which compose this genus are distinguished at once by their diminutive size, by the rich golden crown of their heads, and by the minute comb-like feather which covers their nostrils. Although so diminutive, they are a courageous, spirited, hardy, and active family; enduring, even in the cold countries of the North, the severities of the hardest winter. Their habits, food, nidification, the number and colour of their eggs, bring them in close connexion with the Titmice, while their more feeble but sweetly modulated song, and comparatively weak bill indicate their alliance to the Sylviadee, from which combination of characters it may be a matter of doubt whether its true station is among the former or the latter. On this point we leave the reader to form his own conclusions; although, for ourselves, we are inclined to consider its alliance to the Titmice as based upon the most solid grounds.

We have, however, to notice a new claimant in one of the present family, to a place in the Fauna of Great Britain, which has been long known as a continental species under the name of $R$. ignicapillus. The authority we possess for adding this name to the list of British Birds rests not upon our own observation, but upon the testimony of an accurate and attentive observer of nature, the Rev. L. Jenyns, of Swaffham Bulbeck, Cambridgeshire, who exhibited a recent specimen (accidentally killed near his own residence,) before the Committee of Science and Correspondence of the Zoological Society of London, at the meeting of the 14th of August 1832.

If this bird has been hitherto overlooked in England, the omission has arisen from its close similarity to the common species; we have therefore figured both in one Plate, that their differences may be more clearly perceived. The true habitat of the Fire-crested Wren appears to be confined to the southern portions of Europe, being found in abundance in France, Belgium, and the eastern provinces. In its habits, manners, food, and nidification, it strictly resembles the Golden-crested Wren, from which it differs in plumage in the following points. Its crest is more fiery ; the sides of the neck and top of the back more tinged with a golden lustre; and in the alternate stripes of black and white, which occupy the sides of the face, both above and below the eye; the under surface is also rather more grey; its size is the same, or as nearly so as possible.

\section{GOLDEN-CRESTEDWREN.}

\author{
Regulus vulgaris, Cuv. \\ Le Roitelet ordinaire.
}

THE Golden-crested Wren is the smallest of the European Birds, and is generally dispersed in every region from the Arctic circle to the utmost limit of the warm and sultry regions of the South : in the British Isles it is to be found throughout every district, inhabiting woods, coppices and hedgerows, but especially plantations of Fir and Oak, where they appear to be companions with several of the species of the Tits, particularly Parus cœruleus and ater, with which they may be generally observed engaged in scrutinizing the highest and outmost branches of trees, clinging with ease and dexterity to the under surface, prying inquisitively into every crevice in search of insects and their larvæ, which, with tender buds and small seeds, constitute their food. We have observed that this species, as well as the Long-tailed Titmouse, which it also sometimes acconpanies, is in the habit of traversing with a certain degree of order and regularity considerable extent of district, returning nearly at a given time to the same locality, so as to perform a circuit of several miles in the course of a single day. Their common call, which is constantly repeated as if to keep the family together, is a weak but shrill cry, so closely resembling that of the Creeper (Certhia familiaris), as scarcely to be distinguished from it. The song, however, which is poured out at the season of nidification is plaintive, sweet and melodious. It constructs a beautiful little rounded nest of moss and lichens, warmly lined with feathers, which is artfully suspended on the under surface of a fir branch, usually near its extremity, and among the thickest foliage, laying from seven to ten very small eggs of a yellowish white colour.

The plumage of the male is of a uniform olive green on the upper surface, the wing-primaries and the tail being brown; the secondaries barred with black and white; the head is ornamented with a beautiful silky golden crest, with an outward border of black capable of elevation or depression at pleasure; the space between the eye and the base of the beak is white, while in the Fire-crested Wren the same part is black; the whole of the under surface is grey, more or less tinged with olive; the beak black; tarsus greenish yellow.

We have figured a male and female of the Golden-crested Wren, and a male only of the Fire-crested, omitting the female of the latter, as there is no distinguishing characteristic. 




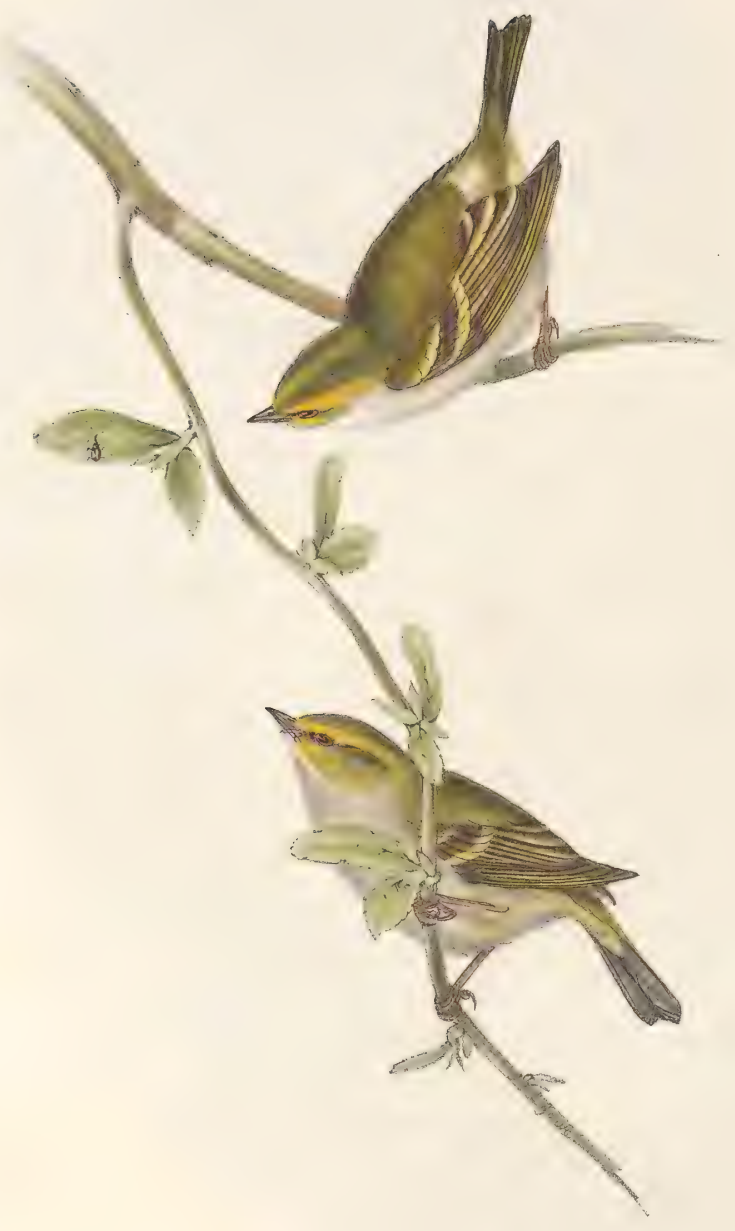

ID $\mathbb{A} \mathbb{L}_{\mathbb{M}} \mathbb{A} \cdot \mathbb{T}^{\top} \mathbb{A} \mathbb{N} \quad \mathbb{R} \mathbb{E} \mathbb{G} U \mathbb{U} \mathbb{S}$.

Regulus modestus. 


\section{A L M A T I A N REGULUS.}

Regulus modestus, Mihi.

A single specimen of this interesting little bird has been sent to us by the Baron de Feldegg of Frankfort, to whom our acknowledgements are due, not only for this instance of his liberality in consigning to our care, at the risk of loss and injury, a bird probably unique in the collections of Europe, but for many other similar instances of disinterested generosity.

The only history of this bird which we have been able to collect was that written on the label attached to it by the gentleman above mentioned, and is as follows: "I shot this bird, which on dissection proved to be a male, in Dalmatia in the year 1829." We were informed at the same time that it was not known to any of the German ornithologists, and consequently that it had not received a specific title; this we have ventured to give, and suggest the term modestus, in allusion to its chaste plumage, and to the absence of the crest, which forms so conspicuous a feature in the other species of the genus, with which we have carefully compared it, and have no hesitation in assigning it a place amongst them as a distinct and genuine species. Judging from its plumage, we believe that the example is fully adult.

Its most conspicuous character are the three yellow stripes which ornament the head; the brighter and most highly coloured of these marks, contrary to what obtains in any of the other Reguli, being that over each eye, while the coronal stripe is palest, and consists of feathers similar in length to those which cover the rest of the head.

Our Plate represents the bird in two different attitudes, to exhibit more clearly its characters and colouring.

With the exception of the stripes on the head, the whole of the upper surface is delicate olive green, becoming abruptly paler on the rump; the quills and tail are brown, edged with pale yellow, which is more conspicuous on the secondaries; two transverse bands of the same colour cross the shoulders; the whole of the under surface is pale greenish white; bill and tarsi brown.

The figures are of the natural size. 










